Portland State University

PDXScholar

\title{
A New Approach to Explain Policy Reforms in Vietnam during Đổi Mới by Developing and Validating a Major Policy Change Model for Vietnam
}

Huan Van Dang

Portland State University

Follow this and additional works at: https://pdxscholar.library.pdx.edu/open_access_etds

Part of the Higher Education Commons

Let us know how access to this document benefits you.

\section{Recommended Citation}

Dang, Huan Van, "A New Approach to Explain Policy Reforms in Vietnam during Đổi Mới by Developing and Validating a Major Policy Change Model for Vietnam" (2013). Dissertations and Theses. Paper 611. https://doi.org/10.15760/etd.611

This Dissertation is brought to you for free and open access. It has been accepted for inclusion in Dissertations and Theses by an authorized administrator of PDXScholar. Please contact us if we can make this document more accessible: pdxscholar@pdx.edu. 
A New Approach to Explain Policy Reforms in Vietnam during Đổi Mới by

Developing and Validating a Major Policy Change Model for Vietnam

by

Huan Van Dang

A dissertation submitted in partial fulfillment of the

requirements for the degree of

Doctor of Philosophy

in

Public Affairs and Policy

\author{
Dissertation Committee: \\ Craig Shinn, Chair \\ Douglas Morgan \\ Marcus Ingle \\ Bruce Gilley \\ John Gallup
}

Portland State University

2013 
Copyright (C) 2012 Huan Van Dang 


\begin{abstract}
The Renovation Program - Đổi Mới in Vietnam since 1986 have posed a puzzling policy question: why have some policy areas experienced radical changes while others have experienced only limited and incremental changes? This policy puzzle provided the focus for this dissertation in which a model of major policy change was developed to provide a new way of explaining the policy reforms in Vietnam over the past two decades. The model was developed based on three bodies of literature: (1) the most well-developed theories and models of policy change process created in the U.S and their application to the non-U.S. policy contexts; (2) the Policy-elite model as an alternative to explain the policy reforms in developing countries; (3) critical and unique regime characteristics of Vietnam that play an important role in shaping the policy contexts for the policy processes and outcomes in Vietnam.

Taken together, these bodies of literature provided the basic concepts and suggested potential causal mechanism of major policy change for a conceptual framework to build a major policy change model for Vietnam. The proposed policy model identifies four policy factors (stressor, leadership predisposition, change in policy image and consensus on the political priority) that need to occur at different stages of the policy process in Vietnam to make radical change happen. Owning to the unique regime characteristics of Vietnam, the model differs from other policy process theories and models in the way that it strongly emphasizes the role of the Communist Party and the predisposition to reform embraced by the policy elites in the process of major policy change. It also reflects the collective and consensus-based policy making


style of the Vietnamese Communist Party and government in the transitional period of the country.

The explanatory capacity of the proposed policy model was validated by four policy case studies in higher education, international trade liberalization, state economic sector, and legal reform in foreign investment in Vietnam. The empirical evidence drawn from the case studies has affirmed the usefulness and relevance of the policy factors and the causal flow embedded in the proposed model. Concretely, the two cases with radical policy changes witnessed the presence of all four policy factors and the processes of change followed the causal arguments of the model. Whereas, in the two cases without radical changes, the legacy of a Socialist state in Vietnam has impeded the significant changes in the policy image of the policy elites in respective policy domains. As the result, no innovative policy change alternative has been advanced to the agendas of the Vietnamese government, which in turn prohibited radical policy changes in the areas of higher education and state-owned enterprise over the past two decades.

In the last chapter, the cross-case comparison has found that in all four cases, there have been strong stressors and the leaders of the Vietnamese Communist Party and government have felt great pressure to reform. The Party has shown the predisposition to reform in various guiding resolutions in the four policy sectors. Yet, in the cases of higher education policy on institutional autonomy and state-owned enterprise management policy, the lack of significant change in the policy image of the leaders has been the main reason for the absence of innovative policy change. In contrast, in the cases of international trade liberalization and legal reform in setting 
the level playing field for enterprises of all economic sectors, all the policy factors have occurred to produce radical policy changes in these two areas. 


\section{Dedication}

I dedicate this dissertation to all of my dear family members who have given me so much love, trust, and strength. A great respect to my grandmother, whose wisdom illuminates every step I go. Special feelings of gratitude to my parents, whose resilience and beliefs in a better future inspire me. And to my significant other, my wife - Phương Anh, whose love, care, and intelligence ceaselessly motivate me to go beyond my assumed capacity. 


\section{Acknowledgments}

I would like to acknowledge the many people who helped me complete this dissertation. I am thankful to my advisor committee members for all of their support and assistance during the process of accomplishing this dissertation. Dr. Craig Shinn, as committee chair, took a true leadership role in coordinating the support and guidelines of all committee members. His instructions on the research methods and on the structure of the dissertation were very important to the overall development of my research. Dr. Douglas Morgan was extremely helpful in the creation and development of the arguments in every section of my dissertation. The intensive discussions with him helped me clarify and consolidate the key ideas of the dissertation. With his vast knowledge in the Vietnamese politics and culture, Dr. Marcus Ingle provided me with valuable and insightful ideas about the political culture of Vietnam. I am also grateful to his help in securing the financial resources for my last two years of the program. Dr. John Gallup was a pool of resource thanks to his knowledge and experiences in education and economic policies of Vietnam. He spent a great deal of time to review the dissertation with useful comments and suggestions. Last but not least, Dr. Bruce Gilley was helpful in providing me with valuable comparisons between Vietnam and China politics. From the discussions with him and the knowledge gained from his course, I was able to develop critical concepts of my proposed policy change model for Vietnam in the dissertation.

I would also like to thank Professor Steven Esons, Roger Williams University;

Dr. Tran Minh Ca, Vice Chairman of Quang Nam Province; Dr. Le Manh Ha, Vice Chairman of Ho Chi Minh City; Mr. Bui Manh Cuong, Deputy Director, Supreme 
People's Procuracy of Vietnam; Mr. Nguyen Ngoc Lam, Deputy Head, the Central Committee of Organization and Personnel of the CPV; Dr. Dinh Duy Hoa, Director General, Department of Administration Reform, Ministry of Home Affairs; Dr. Do Huy Thinh, late Director of the SEAMEO Regional Training Center; Dr. Nguyen Loc, Deputy Director, the National Institute of Educational Science of Vietnam; Dr. Le Dong Phuong, Director, Higher Education Division of the National Institute of Educational Science of Vietnam, who have shared with me important information and insights of the political system and the policy process in different policy areas in Vietnam.

Finally, my gratitude goes to Mr. Tran Ba Viet Dung, Director General, Department of International Cooperation; Mr. Nguyen Xuan Vang, Director General, Department of International Education; Mr. Nguyen Ngoc Hung, former Deputy Director, Department of International Cooperation and my colleagues in the Ministry of Education and Training of Vietnam; and Dr. Gil Latz, former Vice Provost; Dr. Ronald Tammen, Director, Hatfield School of Government; Mr. Phil Keisling, Director of the Center for Public Service; Dr. David Kinsella, Director of the PhD Program in Public Affairs and Policy; and other friends at Portland State University for their strong support. Without their support, I would not be able to participate in and successfully complete this $\mathrm{PhD}$ program at Portland State University. 
Table of Contents

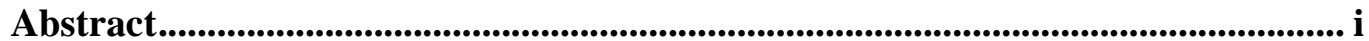

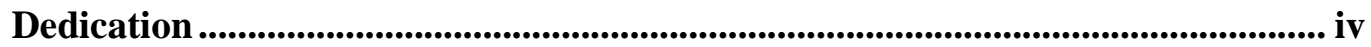

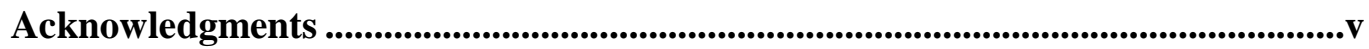

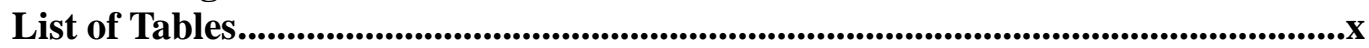

List of Figures.........................................................................................................

Acronyms and Abbreviations............................................................................

Chapter I: Đổi Mới - The Source of the Research Questions ......................................1

1. Achievements and challenges in Đổi Mới................................................1

2. Policy change outcomes in some key areas .................................................

3. Research questions and the structure of the dissertation...........................10

Chapter II: Literature Review .........................................................................14

1. Theories and models of the policy process in the U.S context..................15

Key concepts in the theories of policy process ..................................16

The Punctuated-equilibrium theory (PE) .......................................23

The Advocacy-coalition framework (ACF) ......................................26

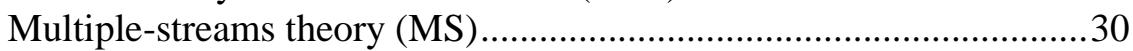

The Policy-regime model (PR) and Focusing-event model (FE) .........34

Summary of the policy process theories and models in the U.S context

2. The applicability of policy process theories in non-U.S. policy contexts ..43

Critics of Advocacy-coalition framework (ACF) ................................44

Critics of Punctuated-equilibrium theory (PE) ...................................4 47

Critics of Multiple-streams theory (MS) ..........................................48

Conclusion on the application of the U.S theories in non-U.S. contexts
\end{abstract}

3. Policy-elite model: an alternative explanation of policy reform in developing countries............................................................................51

4. Vietnam regime characteristics: implications for policy context...............54

Institutional structure of the central authority....................................55

The relationships between central and local governments..................58

The policy-making structure ….......................................................6 60

The relationship between the state and society .................................63

Conclusion on the characteristics of the policy process and structure in

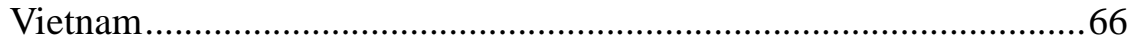

Chapter III: Proposed Model of Major Policy Change in Vietnam .......................69

1. Explanation of components of the major policy change model for Vietnam

Different stages of the policy process (Column A) ............................ 72

Critical policy change factors (Column B) ........................................ 75

Different kinds of policy outcomes (Column C)..................................8 81

2. Integrative description of the Major Policy Change Model for Vietnam ..83

3. Generated propositions to validate the policy model ...............................88

Chapter IV: Research Design and Methodology to Validate the Proposed Model of Major Policy Change in Vietnam. 
1. Research design

2. The analysis framework for the case studies to validate the policy model93

3. Data collection methods....

Chapter V: A Case of Incremental Policy Change in Institutional Autonomy for Higher Education Institutions in Vietnam.............................................................99

1. Introduction to the Vietnamese higher education system: indicators, challenges and policy change during Đổi Mói

Government objectives of higher education in Vietnam

The capacity and expansion of the Vietnamese higher education system

The quality of the higher education system

Incremental governance changes in higher education

The Vietnamese governmental policy on autonomy for higher education institutions

2. Case analysis: how policy factors determine policy outcomes?.

The stressors to higher education policy

Leadership predisposition to reform state management in higher education.

Policy image on state management in higher education

Additional evidence of the policy image of the policy elites in MOET

3. Process-tracking of the cases.................................................................146

4. Conclusions on the relevance of the proposed policy change model to the

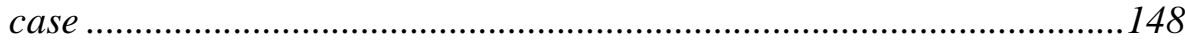

The Party and government have recognized the stressors for reform in

higher education. 148

The Party and government have demonstrated a predisposition to reform.....

The lack of significant change in policy image prohibited innovative change in higher education policy on institutional autonomy ...........151

Chapter VI: How was radical policy change made under the Bilateral Trade Agreement between Vietnam and U.S?

1. Introduction to the case: Đổi Móri and the requirements for trade liberalization.

Critical turning points in Vietnam's accession to the WTO.

2. The potential benefits and challenges in liberalizing Vietnam's trade policy

Potential benefits from international trade agreements

Challenges to Vietnam when deeper liberalization of international trade

3. Case analysis: how did policy factors influence the outcomes?..............166

The role of stressors in accelerating trade reforms ............................. 168

Leadership predisposition to radical change in international trade.... 172

Change in policy image of the regime to the BTA with the U.S........ 175

Consensus on political priorities as the sufficient condition for radical

policy change.

4. Conclusion on the relevance of the proposed policy change model to the case 
Chapter VII: A Case of Lacking Significant Policy Image Change in State-owned

Enterprise Management in Vietnam ........................................................................193

1. Introduction to the state economic sector in Vietnam ............................195

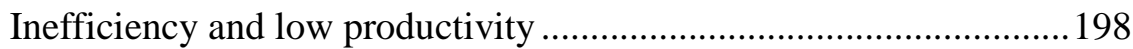

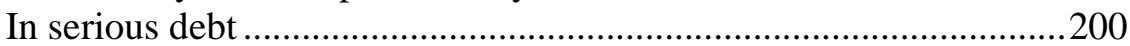

Non-core investment ...................................................................... 201

2. Case analysis: explaining the lack of radical change in state-owned

enterprise management policy of Vietnam .............................................207

Increasing stressors for reforms in state economic sector.................208

Strong leadership predisposition to reform in state economic sector 213

The lack of significant change in policy image prohibits adoption of radical policy change

3. Conclusion on the relevance of the proposed Policy Model to the case..228

Chapter VIII: A Radical Legal Change in Foreign Investment in Response to the

Stressors from WTO Accession.

1. Vietnam economic performance prior to 2005 and key legal changes in the area of foreign investment in Vietnam....................................................233

2. Policy process in setting the equal legal status for all types of enterprises

Analysis of the policy change process in establishing equal playing field

for foreign-owned enterprises in Vietnam............................................241

The role of stressors in initiating foreign investment legal reform....242

Leadership predisposition to create an equal legal status for foreign

enterprises

The significant change in policy image in foreign investment sector 250

Political priority of CPV in the first years of the $21^{\text {st }}$ century ...........255

4. Conclusion on the relevance of the policy change model to the case......257

Chapter IX: Conclusion

1. The relevance and explanatory capacity of the proposed major policy

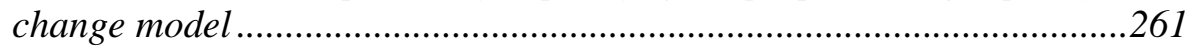

The role of four policy factors in the policy change process in Vietnam

The relevance of the causal flow of the policy change model in the cases .....

Policy implications to the policy process in Vietnam

2. Contribution of the proposed policy model to the policy process literature

Contribution to the literature body of policy process theory and model

Contribution to the literature body of policy process and politics of

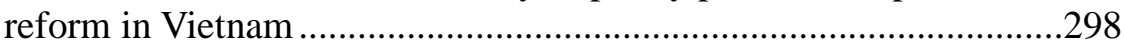

3. Limitations of the research and proposed future research .......................300

The limitations of the research......................................................301

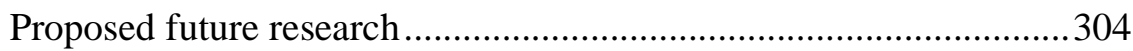

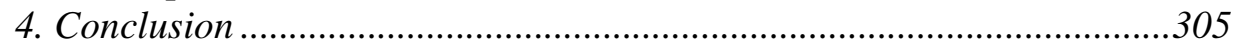

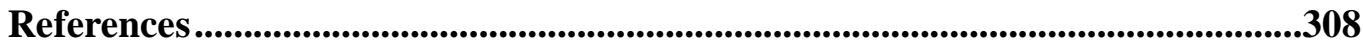

Appendix: Key contents of Vietnam Higher Education Law of 2012 related to institutional autonomy of higher education institutions. 


\section{List of Tables}

Table 1: Types of policy-oriented learning model .21

Table 2: Policy theories/models and factors associated with major policy change .....43

Table 3: The relevance of the policy factors to major policy change in Vietnam.........70

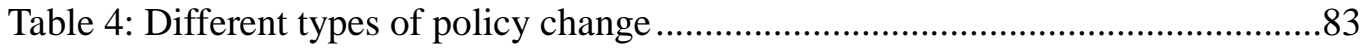

Table 5: The relationships between policy factors and major policy outcomes in four cases 97

Table 6: Different types of data and information sources .......................................97

Table 7: Operationalize the policy change factors of the model...............................98

Table 8: Major policies and practices that support decentralization in higher education

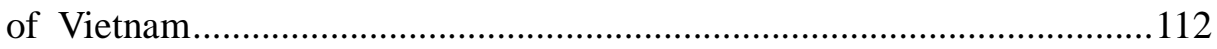

Table 9: Major policies \& practices that limits autonomy of higher education institutions in Vietnam.........................................117

Table 10: Timeline of Vietnam's accession process to WTO ..................................160

Table 11: Resolutions, decrees, \& directives of the CVP \& government regulating the

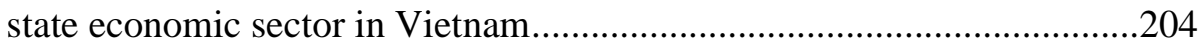

Table 12: Categorization of state-owned enterprises based on Prime Minister's

Resolution No. 929 .225

Table 13: Summary of legal changes in Vietnam's foreign investment in the period from $1987-2005$. .240

Table 14: The relationships between policy factors and major policy outcomes in four cases. 


\section{List of Figures}

Figure 1: Proposed model of major policy change in Vietnam......................71 


\section{Acronyms and Abbreviations}

$\mathrm{ACF}$

AFTA

ASEAN

BTA

CPV

PCC

Đổi Mới

FDI

GDP

Government:

MOET

MS

NA

PE

$\mathrm{PNC}$

SEG

SGO

SOE

UNDP

WB

WTO

Vinashin

Vinalines

VNUSBTA
Advocacy-coalition Framework

ASEAN Free Trade Area

Association of Southeast Asia Nations

Bilateral Trade Agreement

Communist Party of Vietnam

Party Central Committee

Renovation Program in Vietnam initiated in 1986

Foreign direct investment

Gross domestic production

The Vietnamese Government

Ministry of Education and Training, Vietnam

Multiple-streams Theory

National Assembly of Vietnam

Punctuated-equilibrium Theory

Party National Congress

State economic group

State General Corporation

State-owned enterprise

United Nations Development Program

The World Bank

The World Trade Organization

Vietnam Shipbuilding Industry Group

Vietnam National Shipping Lines

Vietnam-U.S Bilateral Trade Agreement 


\section{Chapter I: Đổi Mới - The Source of the Research Questions}

This first chapter will provide an introduction to the dissertation. In the first section, I am going to review the major socio-economic achievements and challenges during the Renovation Program - Đổi Mới in Vietnam. This section provides the reader a general background of the socio-economic situation of Vietnam over the past two decades. The second section will introduce the policy change processes and outcomes in some policy areas in Vietnam. This review leads to a puzzling policy question: why have some policy areas experienced radical changes while others have experienced modest and only incremental changes? This puzzling question suggests the research questions for this dissertation. The last section presents how the dissertation is structured and the main contents of each chapter.

\section{Achievements and challenges in Đổi Mới}

In 1986, the Sixth National Congress of the Communist Party of Vietnam adopted a Renovation Program, called Đổi Mới even though the country still retains a single-party and centralized political system with the "unquestionable" leadership of the Vietnamese Communist Party. Đổi Mới is characterized by a shift from a “centralplanning" to a "Socialist-oriented" market economy allowing for the private economic sector development, international economic integration and a number of legal reforms in various policy areas.

The Renovation Program have brought about remarkable achievements for Vietnam in terms of GDP growth, macroeconomic stabilization, export expansion, foreign direct investment (FDI) attraction, and poverty reduction (Vo \& Nguyen, 2009). From 1986 to 2006, the average economic growth rate of Vietnam was $7.1 \%$ making it as one of the fastest growing economies in the world (Vu, 2009). Vietnam's 
GDP reached \$124 billion in 2011, making its GDP per capita US\$1,400 compared to US\$146 in 1990 and US\$630 in 2005 (World Bank, 2011; Chu \& Dickie, 2006). As the result of Đổi Mới, the living standard of a large population was improved. According to the poverty standard set by the Vietnamese government for the period from 2006-2010, in 2010, the country only has $10.7 \%$ of poor households, compared to $18.1 \%$ in 2004 and 58\% in 1993 (General Statistic Office of Vietnam, 2010; Chu \& Dickie, 2006).

As an emerging middle-income country, Vietnam is confronted with critical challenges. The Resolution of the XI Vietnamese Communist Party's National Congress (NPC) in early 2011 emphasized the need to improve the quality of the country's socio-economic development and environmental protection while maintaining the rapid economic growth (Vietnamese Party Resolution, 2011). During the past two decades of development, the contribution of capital to the economic growth has been very high compared to other countries in the region. For instance, in the periods 1990-2000, capital, labor and total factor productivity contributions to the economic growth in Vietnam were $34 \%, 22 \%$, and $44 \%$ respectively while in the period 2000-2008, the proportion was 53\%, 19\%, and 26\% (National Assembly of Vietnam, 2012). This proportion for China in the period from 2000-2008 was $42 \%$, $6 \%$, and $52 \%$, respectively.

For the past four years, Vietnam has had one of the highest inflation rates in Asia, averaging nearly 16 percent a year between 2008 and 2011. The committed foreign direct investment fell significantly from 72 billion USD in 2008 to 14 billion in 2011. Affected by the World Economic Crisis, since 2008, Vietnam's economic growth has continuously slowed down. The average GDP growth of the period 2006- 
2010 was only $7.0 \%$ compared to the target of 7.5-8.0\% (National Assembly of Vietnam, 2012). The growth rate declined under $6 \%$ in 2009 and 2011, the lowest level since 2000. According to Fitch Ratings, the rate of bad loans in the commercial banking system has reached the level of $13 \%$ by 2011 (National Assembly of Vietnam, 2012). Government debt also reached the highest level ever at $57 \%$ of the GDP in 2011 (The Vietnam Consultative Group Meeting, 2011).

The decline of the economy since Vietnam became a middle-income country is a warning that Vietnam needs to avoid the "middle-income" trap if it wants to become an industrialized country by 2020. A recent report from McKinsey Global Institute (2012) pointed out that Vietnam will need to boost its overall labor productivity growth by more than 50 percent, from 4.1 percent annually to 6.4 percent in order for its economy to meet the government's target of 7 to 8 percent annual growth by 2020 . To reach this target, the report emphasizes education and governance reforms as the key solutions. The Consultative Group Meeting at the end of 2011 urged the Vietnamese government to take radical reforms in state economic sector and in public spending in response to economic recession and low performance of state-owned enterprise sector. Most recently in July 2012, an independent report produced by the Economic Committee of the National Assembly of Vietnam with the technical support from UNDP pointed to an economic overhaul to improve the "quality" of the economic growth in the context of the ongoing economic crisis.

In response to the pressures for reform during Đổi Mới, the Vietnamese Communist Party and government have continuously faced a paradox. Indeed, the economic reforms press the state to delegate its powers to the market place and respect international rules. In the meantime, the Party and Government need to 
centralize its authority to maintain its leading role over the society. Economic reforms require commensurate political changes such as changes in higher education, stateowned enterprise, land use policies, or the protection of human rights. Changes in these areas, however, potentially could put the political stability of the country at risk as well as jeopardize centralized control by the regime.

In this transitional period, according to Scott Fritzen (2002), there have been two trends that support state centralization as well as decentralization. The centralization trends are supported by the maintenance of political ideology and government will to ensure a unitary state; dominated executive power over the legislature; state control over civil society and the private sector; and centralized coordination to deal with ideological, global, inter-sectorial and intergovernmental difficulties. Trends that support decentralization include the growth of the private economic sector, the spread of Internet and communication among the populace, and rapid urbanization. In addition to these factors, international integration especially the accession to international economic entities such as WTO, AFTA, or APEC adds more pressures to the trend of decentralization. These pro and cons factors of decentralization have interacted with each other to produce radical policy changes in some policy areas, while prohibiting innovation in other areas.

\section{Policy change outcomes in some key areas}

Over the past two decades since the early of 1990s, the Vietnamese Communist Party and government have made radical policy changes especially changes in creating a level playing field for enterprises of all economic sectors and in liberalizing international trade and investment. Indeed, in 2005 after many times of incremental adjustments, the Enterprise Law and Investment Law were approved to 
remove all the legal discrimination between state-owned and private enterprises and between domestic and foreign enterprises in Vietnam. The two laws have provided an integrative legal framework for the establishment and operation of enterprises in all economic sectors regardless of ownership. The Investment Law of 2005 unified separate laws in the field of investment including Law on Foreign Investment of 1996 (revised in 2000), the Domestic Investment Promotion Law of 1998. The Enterprise Law of 2005 replaced the Enterprise Law of 1999 and the Law on State-owned Enterprises of 2003.

In the area of international trade and investment, Vietnam have signed a number of trade agreements with key partners and adopted radical legal reforms to create favorable conditions for foreign direct investment and international trade. Beginning with the trade agreement with the European Union (EU) in 1992, Vietnam joined the Association of Southeast Asian Nations (ASEAN) and the ASEAN Free Trade Area (AFTA) in 1995 and committed to fulfill the agreements under AFTA by 2006. In 1998, it became a member of the Asia-Pacific Economic Co-operation (APEC), and in 2000, signed the critical Bilateral Trade Agreement with the United States. In November 2006, Vietnam made a major decision to join the World Trade Organization after 11 years of negotiation, marking the completion of the institutional integration into the world economy.

To attract foreign direct investment, the first cornerstone of the legal framework was the Foreign Direct Investment (FDI) Law promulgated in December 1987. At that time, the law was relatively progressive that welcomed FDI in all economic sectors, permitted 100 percent foreign ownership, provided generous tax and duty exemptions in various areas, and guaranteed unrestricted repatriation of 
capital (Chu \& Dickie, 2006). The law was consciously revised in 1990 and 1992 and then replaced by the new Foreign Direct Investment Law of 1996. In response to fierce competitions from countries in the region after the Asian Financial Crisis in 1997, the Vietnamese government adopted many regulatory changes in harmonizing the business environment from 1998-2001 including one-price policy applied to all economic sectors and revised the Foreign Direct Investment Law of 1996 in 2000 to create more favorable conditions for FDI. In 2005, pressed by commitments made under international agreements, in particular the Vietnam-US Bilateral coming into effect from 2002, the full implementation of AFTA agreements and the conditions to access WTO by 2005, Vietnam adopted the unified Investment Law provide equal treatment to foreign-owned enterprises in accordance with the rule of nondiscrimination under WTO (Muller, 2005). The law removes a number of constraints on foreign-owned enterprises such as the constraints on importing goods related to their business lines (Pham H. T., 2011).

In contrast to the radical policy changes in the above areas, there are other policy areas that have produced the opposite results. State-owned enterprise management policy is one such area where there has been no innovative change. Over the past two decades, Vietnam has equitized thousands of small and inefficient stateowned enterprises (SOEs). Yet, the pace and scope of this process is much slower than the case of China ( Vu, 2009). In addition, from 1994, the government decided to consolidate the state economic sector by establishing a number of large state corporations, called the General Corporations. In the same direction, from 2005 to 2010, 12 state economic groups were created by merging the state enterprises in the same business areas into several "mother" companies. By 2009, the share of state- 
owned enterprises (SOEs) in capital, fixed assets, bank credit, and the employment in the enterprise sector was still as high as $39,45,27$, and 19 percent, respectively (The Vietnam Consultative Group Meeting, 2011). This process tends to make the outsiders to think that the Vietnamese government wants to emulate the experience of Japan's Keiretsus and the Republic of Korea's Chaebols (Beresford, 2008). That is, the government proactively subsidizes and invests in strategic economic sectors and enterprises to promote the international competitiveness of the domestic economy. But this is just one side of a coin. Another important reason for the state to consider stateowned enterprises as the cornerstone of the economy is the embrace of the legacy of a Socialist state. State-owned enterprises are expected to help the state monitor and direct the industrialization process of the country and maintain a social welfare delivery system. With this in mind, the government has provided state economic sectors, especially the general corporations and economic groups with various privileges and favorable treatments regardless economic rationale.

Nonetheless, over the past three years, few issues have evoked more passionate debate and public concern in Vietnam than the issue of state ownership in the market economy and the recent scandals related to some state general corporations and economic groups. A series of revelations regarding the poor performance of SOEs and the mismanagement by their leaders and executives were uncovered. According to a report from the Ministry of Finance (Vneconomy, 2012), the total accumulative loss of the state corporations and economic groups by the end of 2011 was 26,100 billion VND (approximately 1.25 billion USD). By September 2011, the total debt amount of state-owned economic enterprises is 415,347 billion VND (around 20 billion USD), occupying up to $16.9 \%$ of the total debt of the banking system. Another problem with 
the state-owned enterprises especially the general corporations and economic groups is their large-scale investments in non-core business activities. Instead of focusing on their core missions and on promoting their international competitiveness, many stateowned enterprises used the preferential loans from the government and state banks to invest in the stock markets, real estates and joint-stock banks for short-term gains.

In the face of pressures and critics of weak oversight and transparency, expansion of non-core business activities, financial mismanagement, and concealing information in the state economic sector, the Vietnamese Communist Party (CPV) and government still stands firm on its policy in this area although incremental changes have been made. The leaders do not necessarily see a contradiction between the existence of a large-scale state economic sector and a dynamic market-oriented economy (The Vietnam Consultative Group Meeting, 2011). In the most important official documents, the CPV and its government continue to consider public enterprises to be the cornerstone of the national economy (Resolution of the XI Party National Congress, 2011). Restructuring the state economic sector has been proposed and implemented but not to diminish the role of this sector. Rather, it is to consolidate the strengths and influences of state-owned enterprises to help government retain control in key economic areas. The ultimate goal is for the Party and government to control the state-owned enterprises as state macroeconomic monitoring instruments and social welfare service delivery system.

Similar to the state economic sector, the Vietnamese Party and government have been reluctant to make radical change in the policy on institutional autonomy for higher education institutions. Despite of rhetorical statements and incremental policy changes over the past years, no specific regulatory framework has been introduced to 
provide substantive institutional autonomy for universities and colleges. In 2005, the Prime Minister called for a "fundamental and comprehensive" renovation in the higher education system in order to achieve dramatic changes in quality, efficiency, and structure that meet the national demand for modernization, industrialization and international integration (Prime Minister's Resolution No. 14, 2005). However, there has been a big gap between intention and the actual and concrete commitments and policies. Key areas related to administrative autonomy and academic freedom are rigorously regulated by the Ministry of Education and Training (MOET) and 12 other line ministries (Hayden \& Lam, 2007).

In June 2012, after a prolonged deliberation and revision, the National Assembly approved the Higher Education Law, which was expected to increase the institutional autonomy of the higher education institutions as a way to address the problems and weaknesses of the higher education system. However, a reading of the new law shows that substantial institutional rights are still conditional and awaiting for the concrete guidelines to be promulgated as the decrees and directives. The law, together with the previous legal documents, has demonstrated the regime's commitment to providing more autonomy for institutions. Yet, this commitment is in very abstract form and there has been no substantive regulatory framework to realize such institutional autonomy due to the strong commitment of the regime to the Socialist legacy. As a result, the government continues to maintain a highly centralized higher education system even in the face of increasing pressures from institutions, the private sectors and the public. 


\section{Research questions and the structure of the dissertation}

From the above reviewed policy phenomenon, a major question arises: Why did radical change seemingly occur more quickly and more completely with something like the introduction of a free market economy or trade liberalization but change has occurred so slowly and incompletely in some areas such as in higher education and state-owned enterprise management? This is the central question I hope to answer in this dissertation. In the process of collecting information to answer this central question, I will also be able to address subsidiary questions and issues. These include: what are the causal factors and mechanisms of major policy change in Vietnam? What are the preconditions that must be in place in order for major policy change to occur in the areas of higher education and state-owned enterprise? How do policy elites in Vietnam function compared to the policy elites in the comparative government literature? What is the relative weight of technical feasibility and political acceptability in determining major policy change in Vietnam? And what is the weight of the role of government and the role of the political party in making radical policy change?

Despite a surge of interest in studying the democratization process and policy changes in Vietnam, there continues to be a lack of research that explores the unique political characteristics of the country as they affect public policy reform. To my knowledge, no researcher has employed policy theories or models to explain policy phenomenon in Vietnam. Most of the policy studies in Vietnam have focused on descriptive inquiries in specific policy areas instead of trying to develop a more systematic descriptive model that might be used to explain and predict policy outcomes in the future. To close this gap in the literature, this dissertation has 
developed an explanatory model of major policy change in Vietnam by drawing from three bodies of knowledge and information. The model was then validated by policy case studies in order to identify its relevance and usefulness in policy change analysis in the case of Vietnam. Thus, the next chapters are structured as following.

In the second chapter, I survey the literature to get the ingredients for a theoretical framework that can be advanced to create a policy model explaining major policy change in Vietnam. The first body of literature examines some of the most well-developed theories and models of major policy change in the contemporary policy process literature in the U.S context. The main objective is to find potential policy factors and causal mechanisms that might explain major policy change. Next, I examine how the reviewed policy change process theories and models work in the non-U.S. policy settings. This is to identify some causal factors of major policy change that might come into play and which are not centrally important in the American-centered policy change theories that I have reviewed. In this chapter, I am also examining the Policy-elite Model that was created by Grindle and Thomas (1991) based on the evidence of policy reforms in 12 developing countries to get additional substances for the theoretical framework of the to-be-built policy model for Vietnam. The third part of the literature review will look at the important and unique regime characteristics of Vietnam that play an important role in shaping the policy context for the policy change process and its outcomes.

Taken together, the three bodies of literature provide me with the basic concepts and suggest a causal mechanism that I have used to build and then to validate a model of major policy change for Vietnam. In Chapter III of my dissertation, I employ the policy change concepts and causal arguments that I have 
drawn from the literature review in Chapter II to develop a major policy change model for Vietnam. This policy model borrows important concepts and causal assumptions of the reviewed theories and models created in the U.S literature but it is based on the regime characteristics of Vietnam. The model emphasizes the role of policy elites and their predisposition to reform in the process of major policy change. It also reflects the collective and consensus-based policy making style of the Vietnamese Communist Party and government in the transitional period of the country.

In chapter IV, I present the research methods that I use to validate the policy model developed in Chapter III. To validate the model, I will employ case study approach in which I select two policy change initiatives that produced major changes and two policy cases that resulted in limited or incremental changes. Specifically, I explain why I am using comparative and qualitative research methods in this study by introducing the use the theory-confirming and theory-infirming approach and processtracking methods in the case studies. I will also explain how I have collected, coded, and analyzed the information to validate the propositions of the proposed model of major policy change for Vietnam.

Chapter V will be dedicated to the master case of higher education policy on autonomy for higher education institutions in which no radical policy change has been seen during the past two decades. This is the case that I have invested the most time and effort in process tracking than the others. Chapter VI, VII and VIII will continue with three junior policy reform cases in the areas of international trade liberalization, state-owned enterprise management, and legal changes to create favorable conditions for foreign-invested enterprises. Among these cases, the two cases related to the 
decision to join World Trade Organization 2006 and the adoption of Investment Law in 2005 involved major change. The third case will be case of state-own enterprise management policy that has witnessed no radical change even when the government faces of fierce criticisms from the public.

Chapter IX will present the discussion on the evidence and data collected from the four case studies. The main objective is to identify the explanatory capacities of the proposed policy model in the analysis of policy processes and outcomes across the cases. I will compare and contrast between the two cases that resulted in radical changes and the other two with only limited or incremental changes. The discussion focuses on linking the evidence of the policy processes and outcomes in the cases with the causal factors and arguments embedded in the policy model developed in Chapter III. In this last chapter, I also identify the implications on the policy process of Vietnam and the contribution of the dissertation to the literature of policy process and the studies of policy reform in Vietnam. Finally, some limitations of the research are identified and the future research is proposed. 


\section{Chapter II: Literature Review}

The main purpose of this chapter is to identify key policy change factors and plausible causal mechanism of change that might be important for developing a major policy change model for Vietnam. In the first part of the chapter, I examine the theories and models that have been developed from the U.S. political contexts and applied to explain the policy processes and outcomes in the U.S policy subsystems. This section helps produce a table of important policy factors and their relevance in explaining major policy changes identified by different policy process theorists in the

U.S. In the second section, I review some selected policy studies that have applied the policy process theories to non-American policy contexts in European and Asian countries. The main objective of section two is to uncover the policy factors that are critical for major policy change in the non-U.S. contexts but are not emphasized in the theories and models created and applied in the U.S. The third section will examine the Policy-elite model that was created by Grindle and Thomas (1991) from the evidence of policy reforms in 12 developing countries. This is an alternative perspective and explanation to the public policy process and reforms in developing countries based on their corresponding regime characteristics. The last section reviews the regime's specific characteristics of Vietnam that are important for a better understanding of the causal factors and mechanisms associated with major policy change in Vietnam. Taken together, these bodies of literature provide me with the basic concepts and suggest causal mechanism of major policy change that I use to build and validate a model of major policy change for Vietnam in the next chapters. 


\section{Theories and models of the policy process in the U.S context}

Perhaps the most dominant view of policy change in the United States is that change occurs incrementally because institutional arrangements surrounding a policy domain are characterized by stability and continuity. Scholars in the field of policy process studies have used different concepts to describe this phenomenon such as "Policy Monopoly" (Baumgartner \& Jones, 1993), "Policy Subsystem" (Sabatier, 1988), "Policy Network" (Marsh \& Rhodes, 1992; Blanco et al., 2011), or "Policy Regime" (Wilson, 2000). In an influential article, Lindblom (1959) argued that policy makers often act in a reactive and conservative way, and that the political constraints and risk avoidance inhibit them from pushing for policy innovation. Consequently, policy tends to change slowly and incrementally. In another explanation for policy equilibrium, Baumgartner \& Jones (1993) pointed out that the specialized and parallel formal structure of government gives the policy actors the monopoly privileges and powers to resist unfavorable policy change to the status quo. Nonetheless, over the past two decades, a large and expanding body of literature has questioned this perspective by providing compelling theoretical arguments together with empirical evidence for dramatic policy changes (Lowry, 2008).

This body of policy change literature can be organized around the following policy process theories and models:

1. Punctuated-equilibrium (Frank Baumgartner and Bryan Jones, 1993),

2. Advocacy coalition (Paul Sabatier, 1988, 1993),

3. Multiple-stream (John Kingdon, 1984, 1995),

4. The models of Policy-regime (Carter Wilson, 2000) and Focusingevent (Thomas Birkland, 2006). 
Indeed, although all of the above theories acknowledge policy stability and resistance to change as a reality in any policy subsystem, they argue for the plausibility of major policy changes in given conditions and points of time. Each of them employs various policy concepts, and articulates different causal flows to explain how and why major policy changes are transformed into government agenda and then succeed in getting adopted. I will discuss each of the above theories and models with the goal of answering the following three main questions:

a. What does the theory or model tell us about the policy context and the nature of policy change?

b. What are the key causal factors/variables used by the theorists to explain major policy change? What is the mechanism of policy change articulated in the theory/model?

c. What implications can we draw from the theory to develop a conceptual framework for the model of major policy change in Vietnam?

Before examining these theories and models of policy process, it is important to define some of the generic concepts used in the policy process literature.

\section{Key concepts in the theories of policy process}

The following five critical concepts are important to this study and provide a common language for students of the public policy process. While there are sometimes differences in definition, my summary will focus on what policy process scholars all seem to share in common. 


\section{Public policy}

"Public policy", in the most simplified form, is defined as what the government chooses to do or not to do (Birkland, 2001). It can be referred to the intentional course of action followed by government institutions or officials for resolving an issue of public concern (Theodoulou and Kofinis, 2004; Anderson, 2010). More comprehensively, public policy is defined as "a reflection of how people in political society define a good life, and how they try to achieve it through their political institutions” (Morgan, Green, Shinn, \& Robinson, 2008, pp. 317). One important point is that a public policy is not a particular public action, project or program; instead, it is a combination of strategies, guidelines, and actions supported by public resources to change a social condition affecting a given population. In this dissertation the word "policy" is used as shorthand for public policy.

Although scholars in the field of policy study have emphasized different aspects of the definition of public policy, Theodoulou and Kofinis (2004) have provided a set of characteristics that help illuminate the concept of public policy: (1) Includes both policy action and inaction; (2) Involves an array of formal and informal players within and outside the arenas of government; (3) Includes a variety of types of public policy actions; (4) Is focused on achieving an intentional course of action within a specific or sometimes vague goals as its objectives; (5) Is an action that leads to intentional and unintentional consequences; and (6) Follows a definable, yet fluid evolutional course of stages, represented by a pre-decision, decision and post-decision phase of the policy making process. 


\section{Policy process}

It is useful to visualize the policy process as a series of interdependent activities arrayed through time including: agenda setting, policy formulation, policy adoption, policy implementation, policy assessment, and policy adaption (Deleon, 1999; Fritzen \& Muniraa, 2007). Sabatier (1999) defined the process of public policy making as the mechanism in which: (1) problems get conceptualized and brought to government for solution; (2) governmental institutions formulate alternatives and select policy solutions; and (3) those solutions get implemented, evaluated and revised. This "stage heuristic" approach, however, does not view the policy making process as a complex social process which involves politics, psychology, and culture (Dunn, 2008). Schlager (2006) seeks to correct this deficiency by arguing that policy process focuses on unfolding of policy over time and on all of the attending structures, context's constraints and dynamics of the process as well as the actual decisions and events that occur. This definition of policy process takes into account the dynamics of the contexts surrounding a policy domain and thus departs from the conventional structural notion of "iron triangle" where public policy is normally formulated and dominated in a closed system, with predictable policy outcomes (Sabatier, 1988). In this dissertation, I refer to both stage and dynamic approach to policy process.

\section{Theory of the policy process}

Once we have identified the essential characteristics associated with the concepts of public policy and public policy process, what additional elements are necessary to create a theory of the policy process? Elinor Ostrom (1999) has introduced a widely accepted definition of theory of policy process. In a broad sense, 
she argues that a policy process theory places values on some of the variables identified as important in a policy framework, then posits the relationships among variables, and finally makes predictions about the likely policy outcomes (cited in Sabatier, 1999). Compared to a policy framework, a theory of the policy process is more specific in defining each of the policy variables (or factors or concepts), their respective value in relationship to the other variables, and the way in which all of the variables work together to produce policy outcomes. Theories of policy process are important to a public policy researcher for two reasons. First, theories enable the researcher to explain the same policy phenomenon in different ways by selecting and focusing on different kinds of variables (concepts) extracted from different theories. For example, the Advocacy-coalition theory employs three main variables: policy subsystem, belief system, and external perturbation to explain major policy change while the Punctuated-equilibrium theory uses policy image, policy venue/forum, and political mobilization as the key concepts to explain.

A second reason is that policy process theories using the same framework with identical key variables can be differentiated by the way in which each theory places different value on each of the variables. This enables the researcher to assume different relationships among these variables and create diverse hypothesis explaining the same policy phenomenon. For instance, within the Policy Choice Framework created by Grindle and Thomas (1991), by relying on one or another state-centered or society-centered approaches, the policy-elite theory places importance on the values, perceptions, behavior, and institutional position of the individual policy elites while pluralist theory emphasizes the role of values, perceptions, behavior and historical and international contexts of social classes or interest groups as the more important factors 
explaining policy choice and change. In sum, the theories of policy process are useful for policy studies because they help bring in difference lenses to understand and explain policy phenomenon.

Model of policy process

A model is expected to include selected concepts and relationships, which are used to represent a real system (Forrester, 1971 cited in Dunn, 2008). Social models are built to describe, explain, or predict elements and the relationships among the elements of a specific social phenomenon. Models are more specific than theories and are limited in their scope of explanation. Policy models "help distinguish essential from nonessential features of a problem situation, highlight the relationships among important policy factors or variables, and assist in explaining and predicting the consequences of policy choices" (Dunn, 2008, p.86). A model of a policy process in certain policy system may be a simplified representation of such process in an attempt to generalize the relationships among the policy factors, which in turn can help explain and predict policy outcomes. In this dissertation, I am using this concept of policy model.

Policy change

Different scholars define and categorize the concept of policy change in different ways. Roberts and Nancy (1996) in their study on policy entrepreneurship identified two main types of policy change. "First-order" change represents modest adjustments to an existing policy system. In this case, there is no significant change in the overall structure and process of the policy system. Researchers have assigned many names to "first-order" policy change: branch change, evolutionary change, single-loop learning, continuous change, incremental change, and momentum change 
(Roberts and Nancy, 1996, pp. 1-2). In contrast, the second-order change refers to basic change in the system itself instead of a modification of one of its parts. This type of change is characterized by a discontinuity of the old system and a shift to a new one, and thus represents a qualitative rather than quantitative transformation in the way the system works. Again, it has many names: root change, revolutionary change, transformational and paradigm change, radical change, major change, innovative change. This categorization, however, is too broad and cannot differentiate the subtypes of policy change within each of the policy change types. For instance, in some policy processes, a policy outcome may not be a first-order change but also not a second-order change. When this occurs, the policy outcome might be considered to be non-linear succession (Hogwood and Peters, 1982)

Bennett and Howlett (1992) classified different types of change within the government and argued that the change differences resulted from different kinds of learning (see table 1). This definition is helpful in differentiating between policy change and other types of changes such as organizational and program changes. It, however, does not specify different types or dimensions of policy change.

Table 1: Types of policy-oriented learning model

\begin{tabular}{|c|c|c|c|}
\hline Type of change & Type of learning & Who learns & Learns what \\
\hline Organizational change & Government learning & State officials & $\begin{array}{c}\text { Process-related } \\
\text { learning }\end{array}$ \\
\hline Program change & Lesson-drawing & Policy network & Instruments \\
\hline Paradigm/policy change & Social learning & Policy community & Ideas \\
\hline
\end{tabular}

Bennett and Howlett, 1992

Brian Hogwood and Guy Peters (1982) are among the policy scholars who pay much attention to the categorization of policy change. Accordingly, they categorized four ideal types of policy change, including policy maintenance, policy succession, policy termination, and policy innovation (see table 3 in chapter IV). Policy 
maintenance is defined as the continuation of an existing policy, program, or organization with the same task definition. It is a situation that retains the status quo and keeps the policy subsystem intact. Policy succession is defined as a change in which a new policy is closely related in some way to the policy underlying the old program, but may have significantly different policy objectives, program characteristics and/or organizational form.

According to (Hogwood and Peters, 1982), policy innovation differs from policy succession in several important respects. First, policy innovation must overcome the greater barrier of legitimacy for a new policy than policy succession. Second, it involves higher levels of conflict between the new and old policy within the policy subsystem. Finally, it must develop new organizational structures for implementation. One important point related to Hogwood and Peters' categorization of policy change makes it appropriate for a broader application. That is, it identifies the "innovation-succession spectrum", which includes various kinds of policy change lying in between policy succession and policy innovation. The concept of policy innovation defined by Hogwood and Peters (1982) is similar to the concept of “second-order" or radical policy change articulated by Roberts and Nancy (1996) and the concept of policy succession, to some extent, resembles the definition of "firstorder" policy change. To develop the model of major policy change in this research, I am intensively employing the categorizations of policy change created by Hogwood and Peters as well as by Roberts and Nancy. The words "radical", "major" and "innovative" changes are used interchangeably. 


\section{The Punctuated-equilibrium theory (PE)}

Frank Baumgartner and Bryan Jones (1993) introduced the "punctuatedequilibrium" theory in an effort to encompass and explain both policy stasis and policy punctuation. The term "punctuated-equilibrium" attempts to describe public policy-making as a process characterized by long periods of stability interrupted by a large-scale policy change. The key elements of the theory focus on the foundational characteristics of the political institutions and bounded rational decision-making. In particular, the theorists argue that the political system, like humans, cannot simultaneously consider all the governance issues and problems (True, Jones, \& Baumgarner, 1999). Thus, the government needs to be divided by policy subsystems such as education, defense, trade, economic, etc. This governmental practice allows the political system to engage in parallel processing, but also creates what the authors called "policy monopoly".

A policy monopoly "has a definable institutional structure responsible for policy making in an issue area and its responsibility is supported by some powerful ideas or images" (True et al., 1999, pp. 100). A policy monopoly is comprised of a small group of decision makers who dominate all discourse and policy making related to individual policy issues (Crow, 2009). By controlling the content of policy discussions, a policy monopoly can control the problem definition. Usually, supported by the dominant policy ideas and favorable power structure, the policy monopoly successfully dampens the initiatives for change. As a result, the established policies supported by the policy monopoly are advanced and maintained for a long period of time. Thus, policy is likely to change slowly, and incrementally, which is a common phenomenon in American politics. 
Nonetheless, the authors of the punctuated-equilibrium theory point out that those policy monopolies are not invulnerable forever (Baumgartner \& Jones, 2009). To explain how policy monopolies lose control, paving the way for major policy change, the authors employed the concepts of "policy image" and "policy venue". Policy image is what the policy makers define as the problems and the respective solutions. Policy images are a mixture of empirical information and emotive appeals (True et al., 1999). When an image is supportive of the policy and widely accepted, it is usually associated with a successful policy monopoly. However, at given points of time, interest conflict and oppositional mobilization can occur. These factors create a favorable condition for the emergence of a new policy image, new policy actors, and new policy forums in the policy system.

Notably, the multiple-venue structure in the American political system provides opportunities for policy entrepreneurs to advance the new policy images "out of the box" (Baumgartner and Jones, 1993). That is, the presence of various institutional policy venues can be used to sell an alternative policy image to challenge the established one (Walgrave and Varone, 2008). A major policy change is likely to happen when the new image becomes part of the agenda of the macro-political system of the legislature or the chief executive. Usually, the policy image is controlled by the policy monopoly at the policy subsystem at the state level. Major policy changes take place when the policy image escapes from the closed subsystem/policy monopoly at the state level, and advances into the national government's agenda (True et al., 1999). The concept of venue expansion was defined as the circumstance, in which the proponents of an alternative policy image identify friendly policy forum to have their 
voices heard. Here, the role of media and press is critical to attract broad attention to the new policy images and venues.

The PE theory has several implications for the development of the conceptual framework for the model of major policy change in Vietnam. First, the concept of policy monopoly helps explain how the single-party system in Vietnam can use its resources, ideology and information to dampen departure from the status quo, creating only incremental and slow policy changes in certain policy areas. The closed political system and weak independent social organizations reinforce the monopoly of the policy actors inside the public agencies, which in turn affects the momentum of the policy change in Vietnam.

Second, the concepts of bounded rationality and institutional constraints can be used in understanding the behaviors of the policy elites and public officials in the Vietnamese Party and government when they calculate the benefits and risks attached to a major policy change. Together, these concepts help us understand the role of predisposition to policy reform of the policy elites in dealing with different concerns and priorities at given points of time. In the transitional period of time, in the face of both internal and external pressures and priorities, the policy elites in Vietnam may need to anchor their decisions on a set of principles and priorities as the guidelines for their policy-making to avoid unintentional consequences. This can help to explain the "gradualism" and "experimental" approach embraced by the Vietnamese regime in the policy reform process during Đổi Mới. Third, the concept of policy image is important to describe how the Vietnamese policy makers perceive policy problems, anticipate consequences of change and evaluate alternative policies. In a state-led 
policy system like Vietnam, change in the policy images of policy leaders within the regime must occur in advance of any major policy change.

\section{The Advocacy-coalition framework (ACF)}

Paul Sabatier (1988 \& 1993) developed the Advocacy-coalition framework/theory explaining policy change based on the employment of the following key concepts: policy subsystem, advocacy coalition, policy core belief, policy learning, and external perturbation. This model is perhaps the most popular and useful for understanding policy change in modern industrial and open societies like the U.S. This is because it emphasizes a pluralist and democratic political process and practice of decision-making in western democracies. In particular, the theory argues that the best way to understand the policy process and policy change is to look at a policy subsystem rather than at specific institutions or an "iron triangle". A policy subsystem is more formally and politically organized than a policy network. Accordingly, a subsystem usually has a dominant coalition and one or more minority coalitions operating under different beliefs. Coalitions, in turn, comprise actors from a variety of public and private organizations who are actively concerned with a policy issue (e.g., air pollution control or nuclear power) and who regularly seek to influence public policy outcomes that are congruent with their policy beliefs (Sabatier, 1988).

The Advocacy-coalition theory considers shared beliefs among participants as the glue in the creation and maintenance of the advocacy coalitions. The policy belief is a set of value priorities and causal assumptions about how to realize them. A policy belief system of a policy coalition is organized into a hierarchical structure with deep core beliefs, policy core beliefs, and secondary beliefs (Sabatier, 1988). At the highest level are the deep core beliefs that includes basic ontological and normative beliefs 
such as individual freedom or social equality and that the deep core beliefs are very difficult to change. At the lower level are the policy core beliefs, which represent the perceptions concerning value priorities, the seriousness of the policy problems, the principle causes of the problems, and the strategies to realize the core values within the subsystem.

The third level of belief is the secondary aspects of policy which include the expectation of budgetary allocation, the design of specific institutions, or the selection of specific policy instruments in a given policy issue. This secondary belief is easier to change than the policy core beliefs. Among the beliefs, the ACF considers the policy core beliefs as the fundamental glue holding members of a coalition together, not the deep core beliefs or the secondary beliefs (Sabatier, 1999). Within the policy subsystem, different coalitions interact with each other, trying to advance their preferences into policy outcomes, reflecting their policy core beliefs. Notably, this theory identifies the coalition member's "beliefs" as the most important impetus for policy actors who advocate major policy change, rather than economic or political interests.

Sabatier (1988) argued that there are two paths leading to changes in the belief system, which in turn stimulate coalitions, to act for policy changes. In the first place, belief system changes can occur as the result of policy-oriented learning. Policyoriented learning can result from: (1) experiences or deliberative studies that can bring out increased knowledge of origins and parameters of the problem, and the factors affecting them; (2) internal feedback loops; and (3) the changing perceptions based on the impacts of alternative policies. This policy-oriented learning often alters secondary aspects of a coalition's belief system, but not the deep core or policy core 
beliefs. Therefore, the policy outcomes in this case are characterized by the attainment (or revision) of policy objectives, not a policy paradigm shift.

The second path leading to changing coalition beliefs originate from the influences of exogenous perturbation factors that may include: (1) major socioeconomic changes such as economic crisis, or the rise of social movement; (2) changes in the systemic governing coalition such as the result of a national election; (3) the impact of policy changes in other subsystem (Sabatier \& Jenkins-Smith, 1999, pp. 120). These external factors of the subsystem make policy change more likely to happen, and are often the prerequisites to a major policy change. They can dramatically alter the composition and the resources of various coalitions within the subsystem. However, policy change does not occur automatically. The external shocks need to be coupled with the actions of "policy brokers" to provide a catalyst environment for successful major policy change. Accordingly, conflicting strategies from various coalitions are normally mediated by a group of brokers. The policy brokers help the policy coalitions to seek some reasonable compromise that will reduce intense conflict to reach the common ground, allowing for policy change.

To summarize, the basic argument of ACF is that while policy-oriented learning is an important aspect of policy change and can often alter secondary aspects of a coalition's belief system, changes in the core aspects of a policy are usually the results of perturbations in non-cognitive factors external to the subsystem such as macro-economic conditions or the rise of a new systemic governing coalition. Thus, for major policy to occur there must be a form of perturbation to the subsystem, which is coupled with the active role of policy brokers in order to realize the opportunity window for major policy change. 
The Advocacy-coalition theory has both strengths and weaknesses in explaining major policy change in Vietnam. In the first place, it offers some useful concepts for the development of the conceptual framework for a model of major policy change for Vietnam. For instance, similar to the concept of policy monopoly, the concept of policy subsystem helps explain policy stability and the resistance to policy innovation in Vietnam. Powerful bureaucratic groups in the policy subsystems may act against any proposal or initiative of changes to protect their privileges and beliefs.

Second, the categorization of policy beliefs is useful to order the priorities and values embraced by the policy elites in the Vietnamese Communist Party and government when they consider proposals for policy changes. The deep core belief concept is close to the concept of "political principle" set forth by the Party and government in Vietnam and the concept of policy core belief is close to the concept of political tactics in Vietnam. Third, the concept of policy-oriented learning captures the technical learning of policy instruments and implementation methods that is relevant to explain non-radical changes as the result of policy-oriented learning in various policy domains in Vietnam.

The ACF, however, has limitations in explaining policy phenomenon in Vietnam. First, like the Punctuated-equilibrium theory, it assumes a pluralist and democratic political system and policy-making process common to western and developed countries. The theory emphasizes the role of policy advocacy coalitions and policy brokers in the process of policy change. This is not the case of Vietnam where the policy process and reforms are characterized by the principle of "democratic-centralism" and a state-led approach. Often in Vietnam, even though the 
social inputs and international pressures can affect the behaviors of the government and its officials, the policy process takes place within the Party and State circles with limited participation of private and social actors.

Second, the theory emphasizes the role of policy beliefs while overlooking the role of politics and formal power in decision-making. The concept of belief tends to rely on technical rationales more than on political and ideological rationales. This is also not the case of Vietnam where the political principles, priorities and values still dominate the process and outcomes of policy agenda setting, formulation and adoption, especially those policies dealing with sensitive issues, for example, the policy on higher education management. Third, the Advocacy-coalition theory emphasizes the role of policy brokers who may be outside the governmental agencies. This, again, does not reflect the political realities of Vietnam where the civil society is still weak and the participation of non-public actors in the policy process is still limited (Kerkvliet, 2001; Hayton, 2010; and Painter, 2003). Even though, there are connections between public officials and the private and social actors, the preferences and desires of outsiders are still limited and conditional.

\section{Multiple-streams theory (MS)}

John Kingdon (1995) built the Multiple-streams theory of the policy process (MS) based on the approach of the "Garbage Can Model of Organizational Choice" by Cohen, March, and Olson (1972). This theory attempts to explain why some policy proposals become prominent and successfully assimilated into the government's official agenda while others are neglected. Kingdon sees policy change arising from the combination of right timing and skillful manipulation as policy entrepreneurs match policy solutions to policy problems, exploit opportunities, and promote change 
(Wilson, 2000). The author identifies three streams (concepts) that exist independently within a policy system: problem, policy, and politics. Each of the streams is considered as largely separate from the others with its own dynamics and rules (Travis \& Zahariadis, 2002).

The "problem stream" comprises all of the evidence and analysis that document the nature of a policy issue or conditions surrounding a policy domain. The indicators of the conditions can be the magnitude of the problems, or a dramatic event or crisis or the feedback from the existing policies. More important, the problem stream demonstrates how the public officials and policy actors interpret the conditions by applying their values and beliefs (Travis \& Zahariadis, 2002). Thus, not every condition becomes policy problems that require governmental intervention through policy change.

The "policy stream" comprises proposals, strategies, and initiatives to tackle the problems, which exist in a "primeval soup" (Kingdon, 1995). Solutions for given policy issues may come from various policy actors including legislative members, bureaucrats, academics, or researchers who are concerned about and involved in a policy domain. At any point in time, there are always some kinds of solutions floating around within the policy system. Some ideas may survive until adopted, some may be combined into new proposals, and other may disappear (Travis \& Zahariadis, 2002). According to the MS theory, two basic criteria for a policy alternative/solution that should be followed by a policy entrepreneurship are "technical feasibility", and "value acceptability" (See Zhu, 2008). Technical feasibility refers to the demand for details and technicalities of a policy proposal while value acceptability refers to the need for eliminating inconsistencies and political resistance. 
The last stream in Kingdon's theory is the "politics stream" that may consist of party politics, pressures from interest groups, national moods, ideologies or administrative and legislative turnover. Specifically, changes in interest group pressure, swings in the national mood, and the results of elections that bring new administrations to power are some of the most important factors that define the political stream in the United States. The political stream is the most critical avenue toward placing a policy initiative on the official government agenda (Lieberman, 2002). The political stream may also be defined as a venue in which key policy actors can propose, debate, or resist specific policy issues and initiatives (Stout \& Stevens, 2000).

The MS model does not see policymaking as a linear or stage-like process. Instead, each of the streams exists continuously and independently and may become coupled only when a window opens. Thus, the most important argument of the MS model is that issues rise on to the agenda when the three streams joined together at a critical moment in time. This moment is called the "window of opportunity" when the combination of three streams can advance given policy change initiatives. Such windows are opened by compelling problems or by events in the political stream (Travis \& Zahariadis, 2002). They open the opportunities for "advocate of proposals to push their pet solutions or to push attention to their special problems" (Kingdon, 1995, pp. 165).

However, even when an issue is perceived as a problem in all three streams, there is one factor that Kingdon (1995) proposed as the medium through which the policy issue can reach the agenda. That is the role of "policy entrepreneur" which is pivotal in the process of agenda setting. Accordingly, "policy entrepreneurs" are 
defined as those who are willing to devote their time, energy, reputation, and money to make policy changes. An entrepreneur can recognize the problem, attaches an appropriate policy proposal to it, and floats the policy proposal in various forums to bring it to the attention of the elected officials that have the true power to place it on the agenda. Proactive policy entrepreneurs may seek windows of opportunity that create a favorable political climate for the policy being proposed. More specifically, the policy entrepreneurs may promote policy change through: displaying social acuity, defining problems, building teams, or leading by example (Mintrom \& Norman, 2009).

To summarize, the MS theory of the policy process places great importance both on the evolutionary perspective of the government system as well as on the role of the policy entrepreneur for a policy change initiative to be advanced into the official governmental agenda. A policy issue is successfully advanced into the agenda when the three streams - problem, policy and politics - converge together during a window of opportunity. This convergence then must be coupled with the activism of policy entrepreneurs who can seize upon the arising opportunities and advance a policy change initiative to the government agenda. Thus, the theory emphasizes the both cognitive and non-cognitive factors in explaining the policy outcomes. The theory helps answer a popular question: why some policy problems are never addressed by any form of public policy while others succeed in reaching the agenda for policy adoption? Accordingly, agenda setting is the key hurdle for a policy initiative to become a public policy.

The Multiple-streams theory has several implications for the development of the conceptual framework for a policy change model for Vietnam. First, the concepts 
of different streams (problem, policy and politics) are very helpful to clearly identify different components of the context surrounding of a given policy domain. The politics stream is especially useful in calling attention to the role of party politics, which can strongly influence the policy process in Vietnam. Second, like the Advocacy-coalition and Punctuated-equilibrium theories, the Multiple-stream theory emphasizes the roles of policy entrepreneurs in pushing a major policy change that may not be relevant to state-led and consensus-based political systems like Vietnam. Third, although the MS theory is extended by recent work to cover the stage of policy adoption, it only focuses on the initial stage of agenda settings. It does not have a capacity to explain the dynamics of the policy process after the policy issues are advanced into the governmental agenda. Thus, it is limited in explaining the whole process in which policy outcomes are shaped and adopted.

\section{The Policy-regime model (PR) and Focusing-event model (FE)}

In this part, two policy models will be presented: policy-regime and focusingevent models. These two models share a common approach that emphasizes the role of "stressor" or "focusing-event" as the trigger for a major policy change. They connect the exogenous factors outside the policy subsystem and internal process within the government that can affect the outcome of the policy process.

\section{Policy-regime model}

Carter Wilson (2000) made an effort to synthesize different policy theories into a "policy regime" model useful in explaining both policy stability and change. The author employed the concept of "policy regime" as the subject for studying the policy process and for explaining the plausible mechanism of major policy change with an emphasis on the connection between exogenous factors and the political 
process inside the government. Accordingly, the process of policy regime change - the substantial change to a policy regime - occurs with changes in the policy paradigm, alterations in patterns of power and shifts in organizational arrangements. After the old policy regime is replaced, the new one with a new policy paradigm, new patterns of power and new organizational arrangements will operate to maintain long periods of stability.

According to Wilson, similar to the concept of international regime, policy regimes are organized around specific policy areas such as environmental protection, civil rights, education, etc. There are four key dimensions of each policy regime. The first dimension is the power arrangement that consists of at least one or more powerful interest groups supporting and maintaining the policy regime. There may be various patterns of power arrangements that can include interest groups, professional associations, and state actors. Here, author shares the same perspective with Sabatier (1988) in terms of a pluralist policy subsystem in the U.S political process that consists of various policy actors and venues.

The second dimension of a policy regime is the policy paradigm, which shapes the way problems are defined and understood, the types of solutions offered, and the kinds of policies proposed. A paradigm serves as a lens that filters information and focuses attention. It embodies particular assumptions about the policy problem, including: its cause, its seriousness, its pervasiveness, those mostly affected, those responsible for creating it or ameliorating it, and the appropriate governmental response (Wilson, 2000). The concept of policy paradigm is broad enough that can be related to other policy concepts used by other scholars such as policy image 
(Baumgartner and Jones, 1993), policy core belief (Sabatier, 1988, 1993), and the streams of problem and policy (Kingdon, 1995).

The third dimension is the government organization responsible for policymaking and policy implementation in a given area. The policy-making arrangements can include leaders of congressional committees, public agencies, institutions, professional associations and organized interests involved in developing and maintaining the policy (Wilson, 2000). These arrangements may vary from closed iron triangles to more open issue networks. The implementation structure emphasizes the implementing agencies, which in some cases may involve agencies of all government levels from local to state and federal ones.

Finally, the fourth dimension is the policy itself. The policy embodies the goals of the policy regime as well as the rules and routines that are responsible for formulating, legitimizing and implementing the existing policy paradigm (Wilson, 2000). This definition of policy resembles the way Morgan et al, (2008) defined public policy as a combination of both political goals and bureaucratic processes.

Similar to the other theories of the policy process, the policy regime model clearly assumes that every aspect of the policy regime (power, paradigm, organization, and policy itself) contributes to long-term policy stability (Wilson, 2000). To explain the initiation of policy regime change, Wilson (2000) emphasizes the role of exogenous variables with the concept of "stressors" that may include catastrophic events, economic crises, demographic changes, shifts in modes of production, etc. Sometimes stressors produce enough strain to stimulate a rethinking of existing policy arrangements and a consideration of alternatives. They provoke 
questions about the legitimacy of current policy arrangements. They create possibilities and opportunities for radical change.

According to the author, policy regime change tends to occur in stages, although the following stages do not necessarily occur in the same sequence and sometimes occur simultaneously:

1. Stressors/enablers generate stress on organizational arrangements, underscore anomalies in the prevailing policy paradigm, or raise the visibility of new problems.

2. Paradigm shift occurs when events or situations arise that are inconsistent with the dominant policy paradigm, or that can be explained more persuasively by an alternative policy paradigm.

3. A legitimacy crisis occurs when political leaders manage to establish popular doubt in the validity of the stories, images, and authority upon which the established policy regime is based.

4. Power shift occurs when there is a defection of a faction of the dominant policy coalition, rapid mobilization of grassroot organizations, the dissolution of old coalitions and the formation of new ones, or the emergence of new coalitions and new sources of power.

5. Finally, policy regime change involves changes in the policy goals and the organization of policy implementation including change in policy target, policy paradigm, power arrangement, and implementation structure. 
The Policy-regime model has some implications to the conceptual framework for the development of the model of major policy change in Vietnam. First, the model articulates clearly and logically the mechanism of major policy change with welldefined policy concepts such as stressor, policy paradigm, policy regime, and policy regime change. When regimes become stressed, alternative policy paradigms may arise, legitimacy crises occur, and shifts in power and new implementation organizations come into being. However, this synthesis is, as admitted by the author, too general and needs to be specified when applying it to explain given policy phenomena. Second, the concept of stressor, along with the concepts of "external perturbation" and "politics streams" in the Advocacy-coalition and Multiple-stream theory respectively, is helpful for identifying the starting point or the catalyst of a major policy change in Vietnam There is, however, a question of whether or not all of the stressors influencing the government will automatically induce major policy change. To seek the answer to this question, it is important to review the "focusingevent" model of policy change created by Thomas Birkland (2006).

\section{Focusing-event model}

Thomas Birkland (2006) proposed a model of major policy change through four case studies of public policy change surrounding sudden events in the United States: the September 11 terrorist attacks and the Hurricane Katrina. In his model, the author used the notion of focusing-event, which is similar to the concept of "stressor" used in the regime-policy model. At the heart of this focusing-event model is the notion of policy-oriented learning after a focusing-event. Accordingly, Birkland (2006) defined the policy-oriented learning as the process by which "participants use 
information and knowledge to develop, test, and refine their beliefs; the beliefs that motivate political action as well as the beliefs that find their way into policies".

The focusing-event model of policy change generates six propositions regarding the policy process. The first proposition is that most if not all participants in policy domains want to address or solve the problems revealed by a focusing event, but the proposed solutions are likely to vary with the interests and motivations of the interested parties. Participants in a given domain are goal oriented and they each act in order to achieve their goals even in a sudden event. The second proposition is that a few events will gain the most attention. The distribution of damage and deaths in disasters and accidents is not statistically normal. Rather, a large number of relatively small events garner little attention and a few big events garner a great deal. Thus, the magnitude of the damage and the socio-economic impacts of the event determine the influence of the event on the policy change process afterward.

The third proposition argues that group mobilization is linked in time to a particular focusing event. In particular, the activities of groups or the representatives of such groups will become more evident in new accounts of the issue. The fourth proposition posits that group mobilization will be accompanied by an increase in discussion of policy ideas. This discussion will include the ideas about the causes of the problem and potential solutions. The fifth proposition is related to the relationship between idea and policy change. In particular, change is more likely when ideas become more prominent after events than when they do not. The last proposition argues that it is possible for learning to decay over time. While policy change may result from an event, the time that intervenes between one focusing event and another 
and the demands placed on policy makers in that intervening period may cause participants in the policy process to "forget" the lessons they learned.

The generic logical flow of this focusing-event model is as following. When a focusing event happens, the first step is for the event to gain attention. If it fails to gain much attention, it is unlikely to result in much group and policymaker mobilization. The concept of group defined by the author is different from the concept of coalition in Sabatier's advocacy-coalition theory. The groups are relative small, consisting of professional experts, and advocates who are mostly likely to be energized by the event. If there is discernible group mobilization after a focusing event, we should expect to see a discussion of ideas in various forums. In these forums, participants present an exchange of opinions, beliefs, and theories about why the event happened and whether existing policy can address the problems revealed by the event. If the existing policy is shown to have failed, the discussion will include alternative policies that seek to remedy the failure and prevent recurrence.

It is at this stage that we may see considerable evidence of learning. If there is policy change without such discussion and deliberation about the origin of problem, the relevance of existing policy, and the appropriate solutions for the problems revealed after the disasters or crises, it is possible that mimicking or superstitious learning is at work. The author defines this kind of policy change as robot-like because there is little or no discussion and deliberation about the origin of problem, the relevance of existing policy, and the appropriate solutions for the problems. If, by contrast, we can draw a link between ideas, the events, and increased attention to ideas and the new policies, then we have strong evidence of instrumental policy learning and possibly also evidence of social policy learning and political learning. 
In short, a focusing event may influence the policy stream by drawing attention to ideas that were generally unformulated before the event and may create the opportunity for a new look at policies previously considered politically unnecessary. Like the policy-regime theory, a focusing event may change policy makers' understanding of how and why the problem comes about. However, the author is cautious about attributing policy change to any one cause and that focusing events do not automatically bring in policy change. In some cases, the window of opportunity may close before policy change can occur. However, one can say that focusing events make policy change more likely. Also, Birkland (2006) argued that policy change is the function of ideas, but through his study, new ideas were not developed in response to an event. Instead, focusing events tend to reinvigorate attention to preexisting ideas. This view is similar to the view of policy image in the Punctuated-equilibrium theory and the notion of policy stream in the Multiple-streams theory.

There are some important implications of this policy model for the development of the model of major policy change in Vietnam. First, following other theories, the model recognizes that focusing events are necessary to gain the attention of the government and its policy makers. However, the model clearly points to the fact that events may fail to gain much attention, and thus fail to result in change. In this regard, the magnitude of the damage of a given event is correlated to the magnitude of attention to the event. Second, the model focuses on the concept of policy-oriented learning which helps draw a link between idea, information, event, and the motivation to develop new policies. The author differentiates policy-oriented learning from what he calls "mimicking or superstitious learning". That is the case where policy change 
occurs without discussion and deliberation about the policy problems revealed after the disasters and the relevant solutions. In such cases, there is no policy-oriented learning.

The third important implication of the focusing-event model is the argument that a focusing event may change policy makers "understanding of how and why the problem comes about”. But along with regime-policy model (Wilson, 2000), Birkland argued that focusing events do not automatically bring about policy change. In some cases, the window of opportunity may close before policy change can occur. It is the role of the policy champions or leaders to identify such opportunities for major policy change. Thus, for a major policy change to occur there must be both "non-cognitive" and "cognitive" factors. The cognitive factors may include the predisposition to reform of leaders, or groups of actors in the policy subsystem.

\section{Summary of the policy process theories and models in the U.S context}

Table 2 in the next page summarizes the factors identified by the reviewed theories and models that can influence the process of major policy change in the U.S context. These factors can be grouped as the following segments of policy concepts:

1. Stressor - focusing event - external shock - perturbation - national mood

2. Policy monopoly - policy subsystem - policy regime

3. Pluralist and democratic political system (including open and free press)

4. Advocacy group or coalition

5. Policy image - policy paradigm - policy core belief - policy stream policy-oriented learning

6. Policy entrepreneur - policy advocate - policy broker - Policy leader

7. Interest conflict and mobilization 
Table 2: Policy theories/models and factors associated with major policy change

\begin{tabular}{|c|c|c|c|c|c|}
\hline $\begin{array}{c}\text { Theory } \\
\text { Policy factor }\end{array}$ & $\begin{array}{l}\text { Multiple- } \\
\text { stream }\end{array}$ & $\begin{array}{l}\text { Policy } \\
\text { Regime }\end{array}$ & $\begin{array}{l}\text { Advocacy } \\
\text { coalition }\end{array}$ & $\begin{array}{l}\text { Punctuated- } \\
\text { equilibrium }\end{array}$ & $\begin{array}{l}\text { Focusing } \\
\text { event models }\end{array}$ \\
\hline $\begin{array}{l}\text { Exogenous } \\
\text { factor/stressor }\end{array}$ & Medium & High & High & High & High \\
\hline $\begin{array}{l}\text { Dismantled } \\
\text { policy } \\
\text { monopoly }\end{array}$ & Not applicable & High & High & High & Not applicable \\
\hline $\begin{array}{l}\text { Pluralist } \\
\text { political } \\
\text { system }\end{array}$ & High & High & High & High & High \\
\hline $\begin{array}{l}\text { Advocacy } \\
\text { groups }\end{array}$ & Not applicable & High & High & High & High \\
\hline $\begin{array}{l}\text { Policy } \\
\text { entrepreneur }\end{array}$ & High & High & High & High & High \\
\hline $\begin{array}{l}\text { Interest } \\
\text { conflict and } \\
\text { mobilization }\end{array}$ & Not applicable & Medium & Not applicable & High & Not applicable \\
\hline $\begin{array}{l}\text { Change in } \\
\text { policy } \\
\text { image/belief/ } \\
\text { paradigm }\end{array}$ & Not applicable & High & High & High & High \\
\hline
\end{tabular}

Notes: High: must be present for major policy change Medium: to some extent is necessary for major policy change

Not applicable: is not mentioned by or related to the theory

The theories and models of the policy process and policy change reviewed in this section can be useful for the development of a conceptual framework for a major policy change model in Vietnam. Some of the policy concepts and causal arguments may be applicable across countries and policy systems. They, however, may have limitations because they were created for and applied to the U.S policy contexts. For that reason, it is important to examine the application of these theories and models in the non-U.S. policy settings to see how they work.

\section{The applicability of policy process theories in non-U.S. policy contexts}

Over the past decade, an increasing number of policy studies have applied the theories of the policy process created in the U.S to help explain policy phenomenon in European, Asian, and African countries (Olsson, 2009; Nohrstedt, 2009; Walgrave and Varone, 2008; Parsons and Fidler, 2005; Ridde, 2009; Zhu, 2008, etc.). This part of 
the literature review will present some selected critics of the theories of the policy process reviewed in the previous section when they are applied in non-U.S. policy systems. I will focus my review on Advocacy-coalition, Punctuated-equilibrium, and Multiple-streams theories because they are the only ones that have been empirically tested by researchers in non-U.S. contexts. The criticisms of the theories play an important role in identifying the relative importance of the causal factors contributing to major changes in the policy contexts other than the U.S, thus suggesting their applicability to Vietnam.

\section{Critics of Advocacy-coalition framework (ACF)}

Jan Olsson (2009) has employed the Advocacy-coalition framework (ACF) to explore and explain the policy process related to land use and natural resources in Sweden. Olsson found the basic propositions of the ACF important for understanding how policy subsystems work in his case study on Sweden. In particular, the author employed the concept of policy subsystem and advocacy coalition of the ACF to examine policy change in his cases. These concepts of the ACF challenge the notion of "stage heuristic" and "rational decision maker" policy process approaches. Olsson argued that that a policy process theory needs to recognize the complexity of the policy structure with both formal and informal actors and coalitions.

The author also likes the fact that the AFC model focuses on subsystems, which is necessary because policy processes tend to vary between different policy areas. The unique characteristics of a policy area may need a specific contextual understanding that can accurately explain its process and outcomes. Finally, Olsson agreed with the ACF about the importance it places on values and beliefs as inputs in 
the policy process. Because policy subsystems tend to have relatively stable patterns of actors and values it can persist for many years.

The author, however, pointed to some limitations of the ACF in his case studies and proposed some revisions. First, Olsson posited that the model needed to incorporate the concept of "inside activists" in explaining policy change. These inside activists differ from the policy brokers or advocacy coalitions in ACF in some important ways. In particular, an inside activist may be an activist in civic society; hold a formal position in the public sector; and act strategically from this position by using municipality resources. The inside activist has knowledge, capacity and a formal role, taking responsibility for local problems and issues. Thus, inside activists are confined to those working within the government with institutional powers while the policy brokers and advocacy coalitions in the ACF are open to actors from private and non-profit sectors sharing policy core beliefs.

Second, instead of strictly relying on the notion of advocacy coalitions, Olsson emphasizes the role of value networks. The value network concept and the advocacy coalition concept complement each other. An advocacy coalition is political in the sense that it is formed in order to try to influence public policy making, while the existence of the value network is not dependent on a policy subsystem. The value network exists because a number of actors in the society share some common values in a policy issue. If these values are threatened, or if an opportunity to enhance them appears, the network may be mobilized politically, for instance by developing an advocacy coalition. Thus, a persisting value network may develop into a coalition rather quickly, implying much more coalition dynamics than is supposed by the ACF. 
Third, the researcher points to the problematic nature of the ACF concept of "policy broker". Olsson argues that this concept may even prevent analysts from understanding the importance of the professional network and the key role that inside activists play. The author refutes the key assumption of ACF that a policy broker is supposed to play a kind of politically neutral role, helping a "better policy" to triumph over inferior ideas, or assisting with the resolution of conflict through a learning process that ends in a synthesis. Instead, Olsson emphasizes the factor of power rather than implicit and shared normative values in explaining the policy process and policy change. This argument is supported by the results of his case studies, which points to the fact that the concept of power is neglected by the ACF.

In another piece of research on Swedish nuclear energy policy, the researcher argued that due to the political characteristics of Sweden, political judgments had overshadowed policy-oriented beliefs as the primary motive for policy change (Nohrstedt D. , 2009). That means policy actors acted on the basis of their political interests rather than on neutral policy beliefs as argued by the ACF. Thus, to explain policy change in the Swedish context with the active participation of political parties, the ACF needs to take into account the political interests and learning as important causal variables of policy change.

In short, the above researchers together emphasize the need to take into account different causal factors that are overlooked in the ACF model. These factors include the role of key policy actors within the government and political parties and the critical role of power and politics in determining the outcomes of the policy process. These factors contrast to the normative policy core belief that is central to the ACF model. In the political systems with highly centralized political party roles, in 
contrast to the decentralized role of political parties in the U.S, the values and power of the ruling regimes can dominate policy-oriented learning and beliefs and thus direct the final outcomes of the policy process.

\section{Critics of Punctuated-equilibrium theory (PE)}

Stefaan Walgrave and Frederic Varone (2008) used the Punctuated-equilibrium (PE) to explain the critical change in the legal system in Belgium after the Dutroux Crisis in 1998. The research found that shifts in policy images and policy venues are necessary but not sufficient in order for radical policy change to occur. In another word, new policy venues and images do not automatically produce change. In polities dominated by political parties such as Belgium, the political party must be taken into account when explaining radical policy change. A focusing event may attract and increase the attention of media press and the general public. Policy problems and alternative solutions may be clearly identified. Yet, without the political support of the key party actors, major policy change may not be advanced into the government agenda and be adopted. The dominating political parties must become vested in the issue before major policy change can really be adopted.

Walgrave and Varone's case study in Belgium challenges the causal assumptions of the PE theory that the emergence of alternative policy images, coupled with new policy venues and media attention, will produce increasing policy mobilization leading to major policy change. The researchers argued that in order to increase the exploratory power of PE theory in a party-led system like Belgium, the will of the political parties needs to be incorporated as the key causal factor in producing major change. 
In a case study of the internationalization process of higher education in the United Kingdom and Germany, Christine Parsons and Brian Fidler (2005) used the Punctuated-equilibrium theory to explain the pace and scope of higher education reform in these countries. The researcher argued that the external triggers such as financial crisis and governance reform are important for policy change in their cases. However, external crisis must be viewed as serious enough to merit a contingency response (Parsons and Fidler, 2005). Core values and beliefs must be called into question before other elements of the deep structure can be radically changed. In this process, policy champions play an important role. The combination of internal pressures for change advocated by policy champions together with external pressures helps achieve a greater effect on policy change. But external stressors and proactive policy champions are only the necessary conditions for major policy change. A perceived crisis is the most likely catalyst for such change to happen (Parsons and Fidler, 2005).

\section{Critics of Multiple-streams theory (MS)}

Xufeng Zhu (2008) has employed the Multiple-streams (MS) theory to explain a radical change in China's policy on "Detention and Repatriation". Instead of applying all the concepts and assumptions of the MS theory, Zhu has built the “technical infeasibility” model arguing its contextual relevancy to China's political culture. John Kingdon (1995) argued that "technical feasibility" and "political acceptability" are necessary and sufficient conditions for a policy change proposal to be accepted. Zhu, however, argues that China's party-oriented political system, dominated by strong political and ideological influences enables a major policy change to occur that may not be technically feasible but is politically acceptable. 
Zhu concluded that the doctrine of the political party becomes the most important and dominant element in the politics stream in a country likes China. In addition, because of the workings of the Chinese party-oriented and centralized political and personnel system, officials are less likely to initiate an agenda of policy change that deviates from the Party's strategies and political mainstreams. In a relative closed and state-led policy system, only external forces or perturbations powerful enough to bring wide public attention can challenge the legitimacy of existing policies. In that case, the Chinese authorities may pay attention to the issues at hand and take into account policy change initiatives. If the challenge is not to the core political framework, the authorities may only initiate a policy that is of a lesser political risk or legitimate threat, not a radical change.

The author concluded that Kingdon's policy change model may be useful in China, but with modifications. At the same time, in the course of testing Kingdon's model, the author raised questions about the fundamental differences between Chinese and Western systems. These underlying differences are important in an attempt to use Western policy models or ideas for transplantation to China. The arguments and assumptions of Zhu's research are especially influential on the efforts in this dissertation to develop and validate a unique policy model to explain the policy change process and outcomes in Vietnam.

\section{Conclusion on the application of the U.S theories in non-U.S. contexts}

The studies reviewed in this section indicate the utility and usefulness of the theories of the policy process created in the U.S in explaining policy change in other political systems in European or Asian countries. The researchers have employed key concepts of the theories summarized in Table 1 to explain major policy change in their 
case studies. However, the findings of these researchers suggest that the theories of the policy process created in the U.S need to be revised to enable them to have explanatory power in other countries.

In particular, other explanatory factors overlooked by these theories need to be added or the relative importance of varying causal factors needs to be reexamined according to different policy contexts. For instance, the policy process theories in the U.S tend to emphasize the role of policy entrepreneurs and group mobilization as the key causal factors of major policy change, while the findings of the case studies indicate the critical role of policy elites and activists inside the governments. Another main difference is that policy theorists in the U.S are more concerned with advocacy groups and professional associations that bring in their seemingly neutral and technical beliefs and learning to policy deliberation, while non-U.S. studies emphasize the importance and the central role of political judgments or party predisposition in bringing about major policy change.

The critics of the theories of policy processes created in the U.S when applying to other policy contexts suggest two important points regarding the development of a policy change model for Vietnam. For instance, it is useful and appropriate to employ some of the key and common concepts used by the widely known policy process theories and models for the development of a new policy model for Vietnam. There are some concepts that seem to apply across different political systems such as policy subsystem/monopoly, policy image/belief, stressors/focusing events, political acceptability, etc. Despite the transnational characteristics of the policy process, researches have suggested the importance of building in the unique features of a given regime's policy context to explain policy change process. For this 
reason, the next section will discuss the policy-elite choice model as an alternative explanation of policy change in developing countries. The objective is to provide the basis for abstracting the unique elements in developing countries that need to be incorporated into a model of major policy change in Vietnam.

\section{Policy-elite model: an alternative explanation of policy reform in developing countries}

In this section, I will summarize the "policy-elite" model, which has proven especially important in explaining policy choice and policy change in developing countries. Indeed, Grindle and Thomas (1991) provided a way to close the gap in the policy study literature in general and the policy change theory in particular by advancing the policy-elite model and a series of case studies to explain policy reforms in 12 different developing countries. The model takes the middle view between the society-centered and state-centered approaches to policy choice. The authors argue that specific policy choices are significantly shaped by policy elites who bring in a variety of perceptions, commitments, and resources. But, on the other hand, policy elites are influenced by the external social conditions of the developing countries. Hence, the elite model of policy choice begins with two sets of variables. One set focuses on the background characteristics of policy elites, while the other emphasizes the institutional constraints as well as opportunities created by the broader environmental context of developing countries (Grindle \& Thomas, 1991).

The characteristics of the policy elites related to their policy preferences are considered an internal set of variables that include personal attributes, ideological predispositions, professional expertise, and experiences on similar policy situations, position and power resources, and political and institutional commitments. The 
second set of factors emphasizes the external environment surrounding a policy system in developing countries, including societal pressures and interests, historical and international contexts, and the bureaucratic capacity.

The key assumption of this theory is that the policy process in developing countries is characterized by a high level of state autonomy, fear of economic and political vulnerability, and a weak civil society (Grindle and Thomas, 1991). These important institutional characteristics emphasize the critical role of policy elites in developing countries where elites can proactively define policy problems, formulate appropriate solutions and adopt policy choice through their own perceptions and evaluations. This, in turn, affects how policy and institutional change is initiated, decided and implemented in developing countries. Notably, through the evidence collected in the their case studies, Grindle and Thomas (1991) argued that it is not that the policy elites in developing countries just abuse their powers or are strongly influenced by interest groups. Instead, they are able to make their owned choices based on their own calculation to adopt appropriate policy for their countries.

This model sheds lights on the explanation of policy choices made by the Vietnamese elites in the Vietnamese Communist Party and government in two critical ways. First, it describes accurately the policy contexts in developing countries in which the policy elites and managers have much more autonomy in the policy process compared to their counterparts in developed and industrialized countries. Policy makers in developing and transitional countries emerge as the central actors in the politics of policy reform because developing countries actually have the conditions of uncertainty of information, poverty, pervasive state influence in the economy, and centralization of decision making (Grindle and Thomas, 1991). The concept of 
"ideological predisposition" used by the authors is especially relevant for understanding the policy process and policy choice in Vietnam. In Vietnam, it implies the ideological commitment to a Socialist state, which the regime uses to build its legitimacy. Thus, this commitment explains the attitudes to, and perceptions of policy problems of the policy elites, which in turn determine how they select issues to act on. External stressors may occur and stimulate policy change but policy elites must take into account their ideological commitments and core values of the regime before any major policy change is advanced.

A second value of the policy elite model for the Vietnamese setting is that it helps capture the importance of a closed and centralized political and policy process led by the Communist Party. The model emphasizes internal deliberation and interaction among policy elites within the government and the ruling regime rather than policy coalitions, interest groups or networks, as is the case with pluralist political systems. These inside policy elites are not necessarily isolated from interest groups, international organizations or pressures from the public, but often the environment and reality of underdevelopment and the presence of an unorganized society or passive civil society tend to increase the weight of their power and preferences (Grindle and Thomas, 1991). Even though state powers may be eroded in the globalization process, government elites in developing and centralized countries still possess a high level of autonomy in their policy decisions.

The elite model, however, is limited in explaining the policy process and policy change in several ways. First, the model lists a number of both internal and external factors that can affect the decisions and choices of policy elites in developing country. But the model is not useful in identifying and ordering the importance of 
multiple causal factors associated with major policy change. Thus, it does not meet the standard of a good model that can differentiate critical factors from those that are non-critical (Dunn, 2008). The second limitation of the model is its lack of capacity to explain how these multiple factors interact with each other to induce policy changes. It is also unable to specify different paths of change with the presence of different causal factors that can produce different kinds of policy outcomes.

To summarize, the studies on the application of U.S policy process theories to non-U.S. policy system along with the policy-elite model have suggested the need to revise the existing U.S theories and models of the policy process for accurate explanation of policy phenomenon based on different policy context of Vietnam. This is not especially surprising when one recognizes that the policy contexts are the product of "the intellectual, historical, social and practical conditions in which the subsystem is embedded, consisting of both structural conditions, such as mostly socio-economic factors, and institutionalized rules, norms, ideas and mutual expectations" (Flyvbjerg, 2001, cited in Olsson, 2009). For this reason, it is important to understand the unique regime characteristics of Vietnam and their implications for a better understanding of the policy context in Vietnam.

\section{Vietnam regime characteristics: implications for policy context}

This section will review the main regime characteristics as the determinants for the policy context in Vietnam. This review has two bottom line objectives. The first is to assess the relative importance of the policy change factors identified in the literature reviews of the previous sections corresponding to the Vietnamese context. The second objective is to better understand the key gate keeping mechanisms that both facilitate and obstruct major policy change in Vietnam. 
To identify the key regime characteristics of Vietnam I am referring to the framework presented by Tim Conway (2004) in his analysis of the Vietnamese political system. This framework includes the institutional structure of the central authority, the relationship between local and central governments, and the formal policy making process. Besides these components, I will add a subsection describing the relationships between the state and society.

\section{Institutional structure of the central authority}

The formal structure of the central authority in Vietnam is guided by the principle of "democratic-centralism" with the absolute leadership of the Communist Party of Vietnam (CPV). Formally, the central authority of Vietnam is organized into three separate entities. These include the legislature (National Assembly), the Presidency, and the executive branch (Central Government). Yet, the political structure is organized around an absolute leadership role of the CPV and gives little room for the other political parties and social forces to participate in the political process.

Indeed, the Vietnamese legislative body, called the National Assembly (NA), is unicameral. Currently, $87 \%$ of the NA members are members of the Communist Party of Vietnam (CPV) (Vietnam National Assembly Official Website). The remaining $13 \%$ of the vote was won by candidates who were not officially CPV members, but whose candidacy was approved by the Fatherland Front (FF). The FF is an umbrella organization that is formally established to represent for people from all ethnic minorities, religions, social classes and regions. However, in reality, this organization operates under the political orientation of the CPV. Thus, the $13 \%$ of the NA who are not officially member of the CPV are not in the position that can strongly 
deviate from or be independent of political preferences of the CPV. Constitutionally, the National Assembly selects key leaders of the central government, approves constitutional changes and creates laws, oversees the operation of the government, and determines important socio-economic, defense and security policies of the State (Article 6, Vietnam Constitution, 1992).

Although the 1992 Constitution proclaims the independence of the National Assembly as the supreme entity elected by and representing the people, many observers remain skeptical about the real independence enjoyed by the NA (Conway, 2004; Vu, 2012). As a component of the state apparatus, the NA is under a close supervision of the CPV and places a role as the state entity to legitimize CPV's guidelines and decisions into laws and regulations. In fact, although the Assembly sometimes gives members in the cabinet a critical review, the NA has removed none of them in the past decade, and there remains doubt about their actual accountability for their organizations' performance to the NA. Also, even though there have been increasing claims for substantial roles of the National Assembly, in Vietnam's oneparty system, the legislative role remains weak relative to the executive (Fritzen, 2002).

The second branch of the central authority of Vietnam is the Presidency. The President is elected by the National Assembly (NA) from among its members, and serves a five-year term. The President then selects the Prime Minister also from among the members of the NA and is ratified by the NA. The Prime Minister, in turn, selects members of his/her cabinet, including Deputy Prime Ministers and Ministers. However, in reality, the personnel decisions have always been deliberated and approved within the Central Committee and the Politburo of the CPV before the 
National Assembly Congress legitimizes them. Constitutionally, the President's responsibilities are to officially promulgate the Constitution and laws approved by the National Assembly and to symbolically represent the nation, both domestically and internationally (Vietnam's 1992 Constitution, Article 103).

The third organ of the central authority is the executive, which is formally headed by the Prime Minister. The cabinet, which currently comprises four deputy prime ministers, and the heads of 22 ministries and ministerial organizations, assists the group of top leaders to make important national decisions. All the members of the Cabinet are members of the CPV. In practice, the executive is collectively headed by a small collective leadership group, comprising most notably the General Secretary of the CPV, the Prime Minister, the Chairman of the National Assembly and the President (Conway, 2004). All of these figures are the key members of the Politburo and lead the key organs of the ruling regime: the Party Central Committee, the Central Government, the National Assembly and the Presidency. Important pronouncements by any one of these top leaders are examined and agreed by the others, which ensure that most major speeches and policy announcements are limited to the issues which are uncontroversial among them (Conway, 2004). This mechanism has been called "democratic centralism" as the guiding principle for the operation of the whole political system of Vietnam.

In short, the central authority, even though it is composed of three different entities, is under the absolute leadership of one organization, the Party Central Committee led by the Politburo. The most important and sensitive political and policy issues of the country are initially deliberated and decided within the Politburo before being passed to the Party Central Committee composing of around 170 members. 
Over the years, there has been increasing deliberation on the need for a separation between the roles of the Party and the State and for a balance of power. Yet, the Party's intervention in state management remains dominant (Vu, 2012). The 1992 Constitution indicates a modest downgrading of the role of the CPV by stating that the CPV operates under the Constitution and laws. In reality, the Party, comprising 3.6 million members out of a total population of nearly 90 million, is by far the most important force in the Vietnamese political arena when the legislature, the military and the bureaucracy are effectively subordinate to its guidance (Conway, 2004). Furthermore, the Party committee system exists at every level of the bureaucracy, from the central government to ministerial, provincial, city, district and commune authorities to direct the operation of the state agencies. In addition, the Party's authority is reinforced through the hierarchies of the Party-affiliated mass organizations (e.g. the Women's Union, the Farmers' Association), clustered under the umbrella of the Fatherland Front.

\section{The relationships between central and local governments}

In Vietnam, the formal government system operates at four levels: the central government and local levels including provinces/cities, districts, and communes. There are two main different perspectives regarding the relationship between central and local authorities in Vietnam. First, some argue that the relationship is a "top down" process of strict command and control from central government agencies down to local authorities (Conway, 2004; Hayton, 2010). Under the norms and practices of “democratic-centralism", the central authorities demand (and normally obtains) a monopoly of the formal processes of political mobilization, political representation and decision making across the country. In addition, there is a predisposition towards 
technocratic modes of policy making, with a large number of national research institutes and experts undertaking analysis and providing advice that assist the central agencies in the policy making process for the whole country. To a great extent, this structure reflects the Soviet model of government.

The alternative view of the relationship between central and local authorities is that although the overall socio-economic policies and plans are designed by the central public agencies, a significant degree of autonomy is extended to local administration with regard to implementation (Fritzen, 2000; Painter, 2003). The political system has become significantly less hierarchical over the course of Đổi Mới reforms in which the relationships between the central and lower levels in the formulation and implementation of policy have been radically transformed. Government by decree leaves room for local interpretation and implementation, enabling neccessary refinement and correction that make central decisions more responsive to local situations (Painter, 2003).

To some extent, both of the above views of the relationship between central and local governments are true. Yet, in the view of the author of this paper, the role of the central government is still dominant, especially in the stages of national policy agenda setting, formulation and adoption. There is relatively more autonomy than in the past for local governments especially in regard to policy implementation. However, national laws and regulations are mainly initiated and adopted by the central government with the active roles of its policy agencies and elites, influencing most of the daily life activities of every individual and organization in the society. Depending on the nature of the policy issue, the central government may be more willing than it has been in the past to delegate authority to local governments, but if 
the policy puts at risk the political principles and priorities of the CPV, the Central Party and central government will exercise its right to impose the direction and make the final policy decision.

\section{The policy-making structure}

At the national level, the National Congress of the Vietnamese Communist Party (CPV) convenes every five years to examine and approve broad economic, social, and political strategies for the whole country. Party's resolutions and strategies are then translated into the National Socio-economic Development Plans, which are in turn concretized by a number of annual and sectorial plans and policies created by line ministries for all socio-economic areas and by provincial authorities for the development plans of the provinces. The Party Central Committee also organizes annual meetings to deliberate and decide emerging critical issues for the government and for the whole society. At these annual meetings, the PCC examines law and policy proposals submitted from the government and the National Assembly and produces guidelines and orientations to the state entities.

One critical feature of the policy making structure is the fact that there is a set of national decision-making institutions that consult, facilitate and assist the Politburo, Party Central Committee and central government to design and enforce national policies. These institutions include the Offices of the Party Central Committee, National Assembly, President, and Prime Minister and various ministerial level organizations. In this regard, there are two parallel policy-making systems, one within the Party and the other within the state. When a policy alternative is initiated, formulated, reviewed and adopted, it will be examined by both systems. This dual party-state policy-making process provides two kinds of "policy filters", especially 
for those policies that do not have a high level of internal consensus or when there may be far-reaching external consequences such as land ownership or higher education autonomy. Generally, the state agencies are more concerned about the technical feasibility of a policy alternative. These technical issues include questions about financial allocation and resource adequacy, effective policy tools, cost and benefit calculations, implementation feasibility, etc. The Party's organizations and committees are more concerned about the political acceptability involving the Party's political principles/core values and political priorities such as political stability, the absolute leadership of the Party over the society, the legitimacy of the mainstream ideology, social equality, etc.

There are several important characteristics regarding the decision-making process in Vietnam that are important for the development of a policy change model for Vietnam. First, the policy process may be described as "behavior-led" rather than "rule-led" (Abonyi, 2005). That means, in practice, many formal reforms and regulatory changes often formalize what is already happening in practice in some part of the country or has initially been implemented as "experiments" or pilot projects. This policy practice is characterized by the bounded rational approach of the regime. To manage the unexpected consequences of a radical policy change, the regime allows experimental project to test the policy initiative. A recent example reflecting this practice is the decision to implement a pilot project on abolishing the people's councils at the district level in 10 provinces (National Assembly of Vietnam, 2008). After several years of implementation, the project is continually implemented for the period 2011-2014 before any adjustment to the Constitution is to be made. This practice represents a "gradualism" approach of policy change and process in Vietnam. 
Second, the state relies on being relatively insulated from external political or societal sanctions, such that contradictions can be largely contained within the circles of the party-state system (Painter, 2003). This does not mean that the government ignores the pressures from the public or social groups. Instead, the government tends to filter information and feedback flows and selectively accepts ideas from outside the public sphere. At the central level, a number of consulting agencies and research institutes are created and maintained to provide advice to the policy elites of the regime. The Party and state system are deliberately designed and organized to incorporate political and administrative agencies that help the regime produce harmonious public policies.

Third, the decision-making mechanism in Vietnam places emphasis on collective leadership and consensus (Abonyi, 2005). The objective for effective control and policy implementation by the central actors mandates the internal logic and working of a wide range of institutional arrangements, traditions, and practices that provide opportunities for a variety of agencies, groups, and individuals within the regime to pursue their interests and goals (Painter, 2003). The "democraticcentralism" mechanism involves a number of the elites in the Party, National Assembly and central government in an effort to compromise the political preferences among the key politicians in any critical policy. Most of the important decisions or policies are made by a collective committee comprised of the leaders and experts of concerned agencies to minimize interest conflict and personal responsibility. With this political mechanism of collective mastery, even the top leaders of the Party and Government are not in the position to sustainably impose or arbitrate a major policy change without a broad-based consensus within the regime. This practice leads to a 
"consensus-based" policy process, which represents for the sharing of benefit, responsibility and of political risk but also results in a lack of clearly identifiable accountability.

\section{The relationship between the state and society}

To understand the relationship between the state and society in Vietnam, the following paragraphs will describe the election system, the role of civil society, the legitimacy of the CPV as a sole political party and the political culture of Vietnam, and examine how these factors affect the policy process.

In the first place, Vietnam has two separate election systems: one for the Party, and the other for the State, including the National Assembly (NA) and People Council's elections. Both of these election systems are conducted very five years without an election campaign among the candidates. Theoretically, in the state election system, everyone can be self-nominated as the member of the NA, regardless of social class, religion, ethnics, or political ideology (Constitution of Vietnam, 1992). However, in practice, the final candidates are selected from the so-called "compromising" meetings organized by the Fatherland Front, an organization that operates under the auspices of the CPV. This mechanism of nomination and selection of the legislative members does not allow for the participation of independent policy actors or interest groups in the political process.

On paper, in the Party system, the party leaders at each level are selected directly by the vote of the members of Party's committees at the same level. However, in reality, they are nominated by the predecessor leaders and approved by the higher level of the Party's organizations, which ensures an alignment of views and loyalty among the various party and government levels and between the predecessors and 
successors. After being elected, more than 3,000 representatives of around 3.6 million party members nationwide gather at the National Party Congress to select the leaders of the Party who are also the leaders of the National Assembly, Presidency, and Central Government. Again, in theory, the members of Party Central Committee and the Politburo are elected by all of the participants of the Party Congress. Yet, in reality, they are nominated and selected by the powerful core Party's leaders behind closed doors.

The election practice in Vietnam has several important implications for the policy process. First, the successor party leaders at all levels are nominated and chosen by the predecessor leaders. Therefore, they tend to be loyal to the policies and strategies of their predecessor. This practice makes the policy preferences within the Party and government consistent and stable over time. Second, through the "compromising" conferences that are held at all levels to select the candidates, the Party manages to control the candidacy of the future leaders in the Party, government and National Assembly. A recent practice of leader nomination is the so-called “tentative nomination - quy hoạch cán bộ", which regulates that the future leaders must be identified and nominated as the "tentative leader". Thus, most of the representatives running all levels of government are under the supervision and scrutiny of the CPV. This mechanism helps maintain and consolidate the leadership of the ruling regime overtime.

Regarding the civil society, civil organizations are still weak in Vietnam, largely as a result of deliberate control efforts by the CPV. Civil society refers to the capacity of individuals and groups to organize, speak, write, teach and act without the state's instigation and manipulation (Kerkvliet, 2001). While Vietnam has various 
social associations such as Farmer, Women, Youth Unions and a number of professional and social associations, they operate under the auspices of the Fatherland Front, which in turn is supervised by the CPV (Vu, 2012). Thus, these organizations do not meet the criteria of civil society. In addition, although the Vietnamese Constitution in 1992 declares the right of press freedom, all the mass media agencies fall under the supervision of the Ministry of Culture, Sport and Tourism and the Party's National Committee on Propaganda and Education (Hayton, 2010). The Prime Minister's Degree No 97 (2006) has been publically criticized because it is considered to restrain social deliberation and curtail open society ( $\mathrm{Vu}, 2012)$. As a result, Vietnam NGOs and other signs of civil society have only recently begun to emerge (Kerkvliet, 2001). Tight restrictions make it very difficult for the formation of any organization or interest group that can influence the policy process.

Despite a weak civil society in Vietnam, the regime enjoys a high level of legitimacy. The victories in the wars against foreign enemies in the $20^{\text {st }}$ century and the success of the national unification have given the CPV and its government a great deal of legitimacy. This historical legacy is reinforced by the significant socioeconomic achievements of the Đổi Mới Program, bringing about great improvement in the living standards over the past two decades. In addition, the Vietnamese government has been very proactive in international relations in order to stimulate the trade in and out of Vietnam and therefore making it easy for people to access goods and services at an affordable price (Kerkvliet, 1995). With higher income, more public services, and increased access to basic commodities compared to the period before Đổi Mới, the majority of the population are satisfied with the Đổi Mới process 
initiated and led by the CPV. To a great extent, today the CPV enjoys somewhat greater legitimacy and security than its Chinese counterpart (McCormick, 1998).

Nonetheless, the legitimacy of the CPV as the leader of the whole society is challenged by current social problems, including severe corruption, increasing income inequities, traffic congestion, the failures of state-owned enterprises and the increasing inflation rate over the past few years. In terms of international relations, the regime is also facing critics who want Vietnam to resolve its territorial disputes with China over some important islands. The challenges to the leadership of the CPV are, on the one hand, the major driving forces for policy reforms but, on the other hand, put the Party at risk if major policy changes fail. This paradox strongly influences the process of major policy change that will be articulated in the next parts of this paper.

\section{Conclusion on the characteristics of the policy process and structure in}

\section{Vietnam}

The above review of the regime characteristics of Vietnam has identified some unique features of the policy context in Vietnam. First, national laws and policy changes are initiated and proposed from the bureaucracies that mostly belong to the line ministries in Vietnam. Initiatives and proposals are then submitted to the National Assembly and Central government for deliberation and review with the guideline and direction from the Party Central Committee. This process is characterized by the principle of consensus-seeking and collective decision-making, which does not allow any of the policy actors to exert a dominant role in deciding the laws or policies of the country. Notably, the proposed policies need to be reviewed by both government agencies and Party's organizations. For sensitive and important policy issues, the final decisions on policy outcomes are made within the Politburo and Party Central 
Committee before they are formally approved or rejected by the Prime Minister or the National Assembly.

Second, in the policy making process of Vietnam, the independence of the legislators and policy makers is very limited due to the personnel system used for the advancement and promotion in both party and state systems. Most of the legislators and bureaucratic leaders are members of the CPV and their political interests are strongly linked to the Party's ideology and priorities. The "democratic-centralism" principle does not allow legislators and policy elites to deviate greatly from the mainstream ideology and political preferences of the Party. This reality makes the role of policy champions or entrepreneurs in Vietnam very limited, even though this role is emphasized in most of the policy change theories and practices in the U.S.

Third, party centralization and government control, the constraints on freedom of express and association, and the Confucius culture of Vietnam result in a civic culture that is weak in terms of promoting self-help and organization within the society. Citizens have little opportunity to establish their own organizations in order to speak and act publicly on important policy issues (Kerkvliet, 2001; Hayton, 2010; Vu, 2012). This civic culture, along with the limited capacities of the local governments, tends to make the policy process more state-led and centralized in Vietnam. While a policy reform may be the result of the pressures from the society or international organizations, it is always initiated and advocated by state actors. This view is supported by evidence of the study on policy reforms in 12 developing countries conducted by Grindle and Thomas (1991) whose conclusion is that the closed policymaking system and the weak and unorganized civil society limit the participation of 
social actors in the decision making process and leave higher autonomy for the state actors in policy-making process.

Fourth, in the Vietnamese political system, the accountability mechanism for public agencies and officials is very diffused compared to the U.S and other developed countries. The collective decision making model, along with the dual partystate systems, make it difficult to identify the responsibility of the concerned policy actors in the policy making process. Although the policy-making is centralized, a powerful central individual or agency is generally not in a position to impose policy decisions for which a broad consensus does not yet exist (Conway, 2004). As the result of the collective and consensus decision making style, the initiation and adoption of major policy and institutional reform usually requires sustained, timeconsuming, and nationally-led efforts at consensus building (Painter, 2003). 


\section{Chapter III: Proposed Model of Major Policy Change in Vietnam}

The literature review section has identified important elements of the conceptual framework from which a model of major policy change in Vietnam can be developed. Table 1 in Section 2 of Chapter II has identified the seven (7) critical factors accounting for major policy changes found in the U.S.-centered policy process theories. I have selected two out of these seven policy factors that are relevant to explain major policy change in Vietnam: stressors and change in policy image. Based on three additional reviews on (1) the studies of the applicability of U.S. policy process theories in non-US policy systems, (2) the policy-elite model applied to policy reforms in developing countries and (3) the regime characteristics of Vietnam, I have added two critical factors influencing major policy change in Vietnam:

leadership predisposition to reform of the regime and consensus on political core values/priorities. Table 3 in the nest page summarizes all of the critical change factors and shows how each of the factors is relevant for explaining major policy change in Vietnam. 
Table 3: The relevance of the policy factors to major policy change in Vietnam

\begin{tabular}{|c|c|c|c|c|}
\hline Relevance of factor & High & Medium & Low & Not \\
\hline Policy factor & & & & applicable \\
\hline Stressor/crisis & $\mathrm{X}$ & & & \\
\hline Pluralist political system & & & & $\mathrm{X}$ \\
\hline Advocacy groups & & & $\mathrm{X}$ & \\
\hline Policy entrepreneur/champion & & & $\mathrm{X}$ & \\
\hline Interest conflict and mobilization & & $\mathrm{X}$ & & \\
\hline $\begin{array}{l}\text { Change in policy core } \\
\text { belief/image/paradigm }\end{array}$ & $\mathrm{X}$ & & & \\
\hline Policy-oriented learning & & $\mathrm{X}$ & & \\
\hline Leadership predisposition to reform & $\mathrm{X}$ & & & \\
\hline $\begin{array}{l}\text { Consensus on political core } \\
\text { value/priority }\end{array}$ & $\mathrm{X}$ & & & \\
\hline
\end{tabular}

Notes: High: must be present for major policy change

Medium: to some extent necessary for major policy change

Low: rarely happen or does not have much influence on the policy process

Not applicable: does not exist in the Vietnamese context

In addition to the policy change factors identified as important variables, I

have borrowed the logical flows of the policy-regime and focusing-event models to

build the major policy change model for Vietnam that is illustrated in Figure 1 in the

following page. 
Figure 1. Proposed model of major policy change in Vietnam

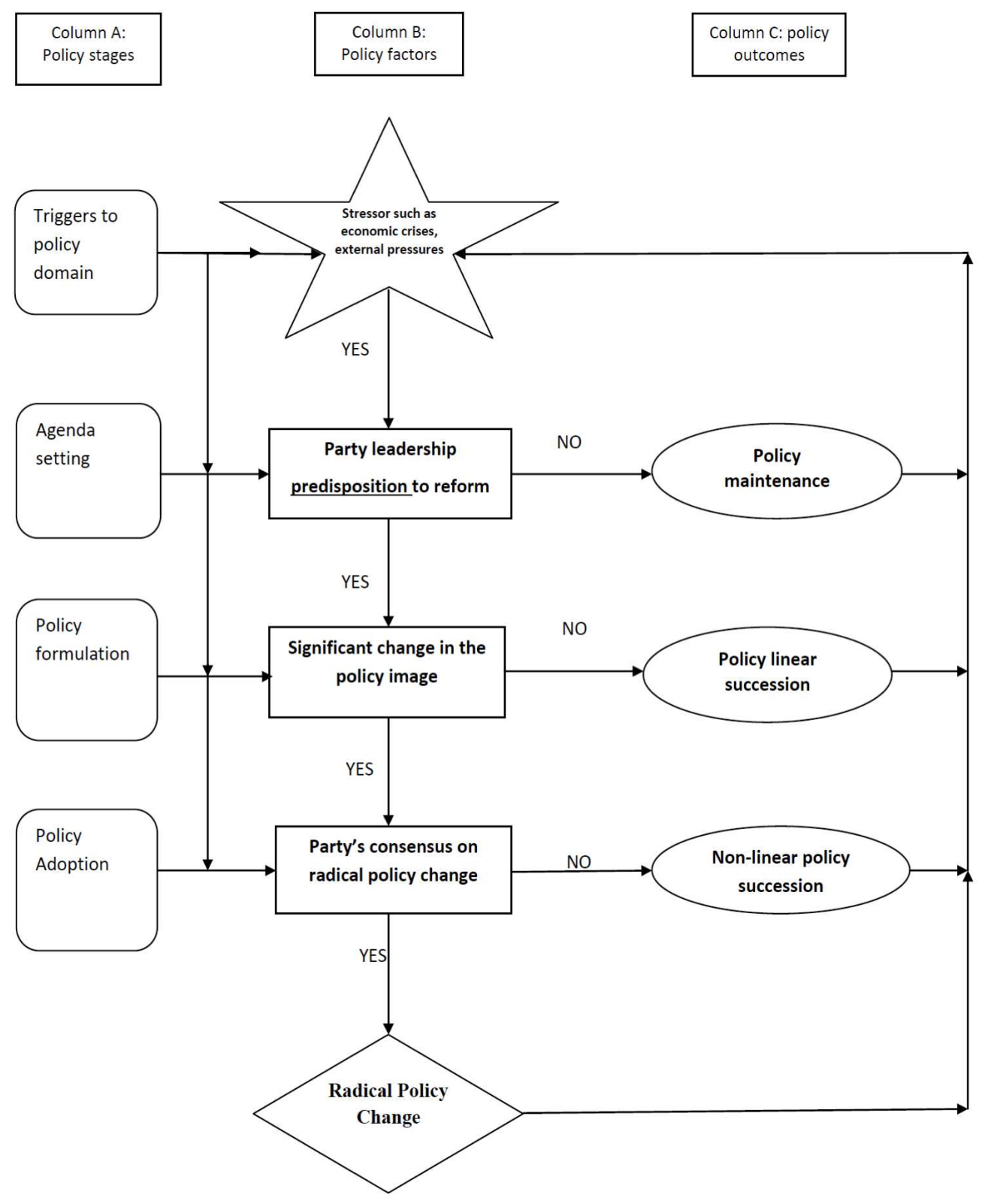




\section{Explanation of components of the major policy change model for Vietnam}

Figure 1 sets forth a major policy change model for Vietnam that I have developed from the review of the policy process literature and of the regime characteristics of Vietnam. In this section, I will explain each of the components of this model and the relationships among the component concepts of the model. At the end, I will conclude with some propositions I generate from the model to guide the validation of the model by the case studies in the next chapters.

The major policy change model for Vietnam in Figure 1 has three main components illustrated by Column A, B, and C. Column A represents different stages of the major policy change process. Column B explains how the policy process proceeds with the presence or absence of different causal factors at different stages of the process. Column $\mathrm{C}$ illustrates different types of possible outcomes of the policy change process depending on the existence or absence of the relevant causal policy factors/variables at different stages. The following sections will explain in detail specific components of the model.

\section{Different stages of the policy process (Column A)}

Column A of Figure 1 explains different stages of the policy process. At each stage, the policy initiative may be advanced to the next stages in the pathway shown in the model to reach the radical change at the end of the process or there will only be other types of policy outcomes. The outcome at each stage depends on the way in which causal factors come into play during the policy process.

Triggers to the policy domain

This is the initial state of a major policy process in the model when stressors or focusing events occur and come into play to challenge the policy monopoly and 
status quo by attracting the attention and concerns of the policy elites to a given policy issue or problem. Similar to other countries' policy system, the stressors to a policy subsystem are the precondition to trigger a major policy change in Vietnam. At this stage, the stressors are documented mostly by the state agencies including line ministries, research institutions and independent studies.

\section{Agenda setting}

This stage determines if any policy change initiative characterized by a new policy goal or paradigm is to be advanced into the government's agenda or not. After the stressors are documented, the state agencies will submitted to the Prime Minister with the coordination of the Office of Prime Minister. The Prime Minister will consider and decide if the stressors need to be responded or not. If the stressors are felt as real challenges, the Prime Minster will report to the Party Central Committee for guidelines. At this stage, the policy elites within the Party and government with their predisposition to reform play a critical role in determining if a radical change policy initiative should be advanced to the Government or National Assembly for further discussion and studies. This is due to the high level of autonomy of policy elites in the Vietnamese centralized and closed policy structure and process that I have elucidated in the review on Vietnam's regime characteristics. Thus, the leadership predisposition to reform can shed light on the advancement of radical policy change initiative to the next stage by the issuance of Party's resolutions or decisions.

\section{Policy formulation}

After the Party shed light on the innovative policy change initiative, the Government or National Assembly will convene concerned and responsible bureaucratic organizations and their representatives to produce and discuss various 
policy change alternative. New information, policy learning, and education will be involved to identify the technical feasibility of the new policy alternatives. A variety of meetings and hearings are organized with an emphasis on the analysis of benefits and consequences of the policy alternatives, appropriate policy instruments, the plausibility of policy implementation. At this stage, the significant changes in the policy image of the policy elites are critical to the formulation of innovative policy change alternative. The policy image in turn depends on how the policy elites relate the policy issues under discussion with the preexisted legacies of a Socialist state. If an innovative policy change alternative is adopted, it is then submitted to the Party Central Committee led by the Politburo for final review and adoption.

\section{Policy adoption}

At this stage, the Party Central Committee with the leadership of the Politburo will review the proposed innovative policy change alternative submitted by the National Assembly or government for final decision. The final decisions will take into accounts the Party's core values, contemporary political priorities and the mechanism of consensus and collective decision-making used by the Party. If the innovative policy change alternative is congruent with Party contemporary priorities while does not directly challenge the core policy values/principles, the chance for it to reach the consensus within the Party is high. It takes time for collective and consensus-based deliberation at this state that can accommodate different views and preferences among the leaders of the Party especially those of the Politburo. If the innovative policy change alternative is adopted, it then will be passed to the National Assembly or Government for official promulgation. If not, it will be delayed or rejected. 


\section{Critical policy change factors (Column B)}

The following paragraphs explain the different causal factors that come into play in the policy change model in Figure 1.

Stressor

Similar to other policy process theories and models, stressors in this model are treated as independent variables of radical policy change in Vietnam. They are defined broadly as critical contextual factors that make major policy changes more likely to happen. Scholars have used different names to label this concept: stressor, focusing event, or external shock/perturbation. Stressors to a policy subsystem in Vietnam may include: natural and human disasters, economic crises, structural changes in socioeconomic conditions, critical changes in other policy areas, national mood, or international pressures. Stressor make the elites fear that adverse consequences may occur if not addressed. Thus, they provide opportunities for policy considering and learning within the policy regime that can change policy makers' perception of the problems, how they rank values or priorities, and how decisive they are in pushing for major policy change. New knowledge, new risks and changes in resource distribution within the regime can lead to innovative policy change initiatives, and provide an environment to trigger a major policy change.

Borrowing the views of other policy process theories and models (Wilson, 2000; Birkland, 2006; Sabatier, 2007), this model also argues that while stressors may be a necessary condition triggering a major policy change, not all exogenous shocks, and not all instances of policy learning are translated into policy change. Several types of requisite for major policy change in response to the stressors must occur. In the case of a state-led and centralized system of government like Vietnam, a superior unit 
of Party or government outside a given policy subsystem must perceive the stressor as a critical factor to the regime's failures or challenges. Thus, they will act on the policy issues and problems revealed by the stressors at hand.

\section{Leadership predisposition to reform}

The second independent variable in this major policy change model is the concept of leadership predisposition. In the policy model proposed in this dissertation, the concept of leadership predisposition was defined as a psychological readiness of the policy elites to consider and advance policy change initiative. This readiness is achieved only after the policy elites take into account the existing stressors along with the ideological commitments and political risks. The predisposition demonstrate the intention to reform a given policy area in response to stressors which is resulted from how the policy elites perceive and articulate particular policy issues, how they assess the proposed change initiatives, and how they weight political and technical factors in dealing with policy problems. Once the predisposition to reform is reached within the leadership of the CPV, the given policy problems and issues will be officially advanced into the agenda of the National Assembly or government for further deliberation and study. This in turn guarantees a chance for a policy reform initiative to be advanced into the next stage of formulation and may be adopted in the future.

Leadership predisposition to policy reform can be linked to ideological loyalties, political commitments and institutional constraints. In the face of multiple stressors, the policy elites of Vietnam can refer to the ideological biases or commitments that influence policy leaders' perceptions of what problems are and how they should be responded to (Alder, 1987 cited in Grindle and Thomas, 1991). The ideological commitments can be guided by the principles of "democratic centralism", 
"social equality", "state of the people", etc. Policy elites have to commit themselves to these principles because these principles represent their deep core beliefs, which also ensure their leadership legitimacy as a single political party representing the labor classes in Vietnam. In addition, the political leaders and policy elites in Vietnam may invoke Ho Chi Minh's thoughts as the rationale for pursuing certain policy goals and undertaking actions within the ruling regime.

A good example illustrating the concept of leadership predisposition to change is Bruce Gilley's (2008) research that contrasted the outcomes of the democratization process in China and Taiwan. Although Taiwan's 1986 successful transition and China's failed 1989 transition both occurred in times of rapid growth, low unemployment, and healthy financial systems, they were greatly different. Gilley attributed the failure of democratization in China to a missing element - the predisposition to major political change of the then Chinese political leaders. They did not perceive that their regime was facing a legitimacy crisis. In contrast, the predisposition of Taiwan's top leaders to the liberalization of the regime is the most critical factor for understanding of political reform in Taiwan. Accordingly, the democratic transition in Taiwan is subjective rather than objective. Thus, in the face of stressors, how the ruling regime and its elites are supportive of reform is critical, especially in centralized and state-led political system like Vietnam or China. Thus, Gilley (2008) argued, "although we can, and must, study the objective conditions that might be defined as "crisis-type" in nature, ultimately there is only a probabilistic connection between this analysis and what relevant actors will subjectively perceive to be a crisis". 
Leadership predisposition is an abstract concept. Yet, in the case of a singleparty and centralized political system of Vietnam its indicators can be identified through the policy statements and guidelines in the Party's documents. Party's predisposition to reform provides the guidelines and legitimacy for a given innovative policy change initiative. Based on the guidelines embedded in Party's resolutions or conclusions, state agencies will advance the initiative into their official agendas. This however does not mean that the Party will automatically approve the final policy alternatives or proposals produced by the National Assembly or government later. Thus, predisposition to reform is only the preliminary perception on the need to change not the determined agreement on reform. Due the fear of failure, the Party needs to involve different type of public organizations including National Assembly's committees, central government's agencies, ministerial agencies, and research institutions, even international advisors or consultative groups. After the policy change alternatives have been formulated, deliberated and selected at the state system, the Party will be the institution to finalize and decide if the innovative policy alternatives are accepted, delayed or rejected.

\section{Policy image and belief}

The concept of "policy image" in this policy model is borrowed from the Punctuated-equilibrium theory. In Punctuated-equilibrium theory, policy image is defined as how policy is understood and discussed. Policy images are a mixture of empirical information and emotive appeals. In the Advocacy-coalition framework, Sabatier (1988) used a similar concept called "policy core belief" which represents the perceptions concerning value priorities, the seriousness of the policy problems, the principle causes of the problems and the strategies to realize core values. Wilson 
(2000) in his Policy-regime model employed the concept of "policy paradigm" that embodies ways of seeing, discussing and defining problems, and then shaping policy solutions. Stressors can challenge the existing policy paradigm of the policy regime and open the possibility for the acceptance of a new policy paradigm.

In the policy model for Vietnam, the concept of "policy image" refers to the way in which the policy actors interpret given policy issues; identify the causal relationships between these issues with the existing policies or the absence of a policy; and rationalize their solutions resolving the issues. Policy image also reflects the assumptions and beliefs in the best way to realize the political priorities of Vietnam regime in the development process. The change in the policy image of the policy elites and makers is a necessary condition for a major policy change initiative to be produced and considered technically feasible. This condition is for the initiative to be advanced to the final stage of adoption.

\section{Consensus on Party's political core values and contemporary priorities}

The concept of political core value is similar to the concept of deep core belief defined by Sabatier (1988). Accordingly, the deep core belief represents basic ontological and normative beliefs such as individual freedom or social equality. Such beliefs are very difficult to change in stable democracies. This is why some of the policy change theories developed in and applied to Western and industrialized countries do not include this kind of belief to explain policy change process and outcome. For example, the Advocacy-coalition Framework (ACF) assumes that the belief in individual freedom has been inculcated in the U.S democracy and governments and is shared by all participants in the society. Therefore, to explain policy change, the ACF does not focus on this type of belief. Instead, major policy 
change only revolves around the policy core beliefs of policy coalitions and actors which represent policy value priorities; the assumptions on the policy problems, and their causes; and the strategies to realize core values. This assumption, however, is not totally true in the case of a developing and transitional country like Vietnam.

Indeed, since Vietnam has integrated into the world community, the core beliefs articulated by the ruling regime are being challenged by the political principles and values of the Western democratic process and governance systems such as pluralism, freedom of press and association, check and balance, etc. The Vietnamese regime maintains its leadership legitimacy based on its ability to keep its core political values dominant over the alternative values from Western and developed societies. For example, the CPV has continued to place primacy on maintaining the democraticcentralism mechanism over a pluralist system, ensuring social equality instead of promoting a free market economy, maintaining social stability over promoting individual freedom and protecting state-led control over the policy process rather than open to a society-led process.

As the result, any major policy change alternative would be assessed against two core values or principles: political stability and the absolute leadership role of the CPV over the state system and the society. Because these principles are abstract, and can be interpreted in a broad sense, the Party's leaders have to refer to some intermediate or subsidiary political goals. For example, the Party can refer to social equality and harmonization, economic development for higher living standard, social welfare for the mass, democratic-centralism, state-led industrialization, etc., when examining a proposal of innovative policy change alternative. At a given of time, the Party will consider among these goals to give the first political priority to certain 
goals. This mechanism plays a role as a "political filter" which is critical to the study of radical policy change in Vietnam. If a given innovative policy change alternative is congruent with the political goals at the time, it will be adopted.

\section{Different kinds of policy outcomes (Column C)}

Although the policy model in this study focuses on explaining radical/major policy change in Vietnam, it includes different types of policy change as the potential outcomes of the policy process. A radical policy change only occurs when all of the necessary and sufficient conditions for it are present. Otherwise, different types of policy change will be produced. For purposes of my study, I have identified four types

of change: policy maintenance, policy linear succession, policy non-linear succession, and radical/innovative policy change, which will be discussed in greater detail in each of the following parts:

\section{Policy maintenance}

The concept of policy maintenance is borrowed from the categorization of policy change introduced by Hogwood and Peters (1982) that includes four ideal types of policy change: policy maintenance, policy succession, policy termination, and policy innovation. The policy maintenance is defined as a change initiative that leaves the existing policy, program, or organization intact. The new policy is implemented without any change in its goals, objectives, and instruments. Policy maintenance may be the decision of the public organizations that nothing is done. Linear and non-linear policy succession

As defined earlier, policy succession is a change initiative to produce a new program that is closely related in some way to the policy underlying the old program, but may have significantly different policy objectives, program characteristics and/or 
organizational form. Within policy succession, policy non-linear succession is characterized by new policy objectives whereas policy linear succession only results in a change in policy instruments or organizational change. The concept of policy succession is similar to the concept of "first-order" change defined by Roberts and Nancy (1996) in their study on policy entrepreneurship. Accordingly, the "first-order" change describes slight variations in a system that it remains unchanged. Researchers have assigned many names to the concept: branch change, evolutionary change, single-loop learning, continuous change, incremental change, and momentum change.

\section{Radical policy change}

In contrast to the first-order change, radical change is considered a "secondorder" when it results in basic changes in the system itself instead of a modification of one of its parts (Roberts \& Nancy, 1996). This type of change is characterized by a discontinuity of the old policy system and a jump to a new one, and thus represents a qualitative rather than quantitative change in the way the system works. The concept of radical change has many names: root change, revolutionary change, transformational and paradigm change, major change, and innovative change (see Roberts and Nancy, 1996). Hogwood and Peters (1982) differentiated between policy innovation and policy succession by arguing that compared to policy succession, policy innovation needs to overcome a much greater barrier of legitimacy. It has to address the conflicting interests between the new and old policy regime within the policy subsystem; and it has to develop new organizational structure for implementation. In short, radical policy change or policy innovation concepts together refer to the change in the goal of the policy, in the way the ruling regime gives priorities to different policy issues, and in the way the existing policy paradigm shifts. 
Table 4 summarizes the four kinds of policy change that I use in my policy change model for Vietnam.

Table 4: Different types of policy change

\begin{tabular}{|c|c|c|c|c|}
\hline $\begin{array}{l}\text { Type of policy } \\
\text { outcome }\end{array}$ & $\begin{array}{c}\text { Policy } \\
\text { maintenance }\end{array}$ & $\begin{array}{l}\text { Policy linear } \\
\text { succession }\end{array}$ & $\begin{array}{l}\text { Policy non- } \\
\text { linear } \\
\text { succession }\end{array}$ & $\begin{array}{c}\text { Radical policy } \\
\text { change/innovation }\end{array}$ \\
\hline Characteristics & $\begin{array}{l}\text { - Old policy } \\
\text { goals } \\
\text { - Old policy } \\
\text { objectives } \\
\text { - Old policy } \\
\text { instruments }\end{array}$ & $\begin{array}{l}\text { - Old policy } \\
\text { goals } \\
\text { - Old policy } \\
\text { objectives } \\
\text { - New policy } \\
\text { instruments }\end{array}$ & $\begin{array}{l}\text { - Old policy } \\
\text { goals } \\
\text { - New policy } \\
\text { objectives } \\
\text { - New policy } \\
\text { instruments }\end{array}$ & $\begin{array}{l}\text { - New policy } \\
\text { paradigms/goals } \\
\text { - Overcomes great barriers } \\
\text { of legitimacy } \\
\text { - Deals with high interest } \\
\text { conflicts } \\
\text { - Create new } \\
\text { implementation structures }\end{array}$ \\
\hline
\end{tabular}

Hogwood and Peters (1982)

\section{Integrative description of the Major Policy Change Model for Vietnam}

In this section, I will describe the integrated model of major policy change for Vietnam that I have developed in this chapter. I will focus my discussion on how the different parts of the Figure 1 relate to one another. Before undertaking this discussion, it is important to define the concept of "policy process model" and identify the characteristics of a good policy model as the guidelines for the development of the major policy change model for Vietnam.

As have been mentioned earlier in Chapter II, the term "model" in the field of policy study is narrower in scope and more precise in its assumptions than a theory to explain specific policy phenomenon (Ostrom, in Sabatier, 1999). A model of the policy process communicates meaningful information about the policy process, including direct inquiry and research, and suggests explanations for the way the public policy process works, including the inter-related connections among the component parts of the process (Sabatier, 1999). A policy process models should suggest hypotheses about the causes and consequences of public policy (Dye, 1992, cited in Birkland, 2006). 
Birkland (2006) identified several important characteristics of a good policy model. First, it must seek to order and simplify reality; identify what is significant about the system; and square it with reality to the extent that this is possible. Second, a model needs to be parsimonious both in its forms and in the phenomenon it is attempting to describe. Third, a model must help us to generate propositions about the policy mechanisms and outcomes. In addition to these criteria, a good model must have concepts and propositions that are clear and internally consistent. It must identify clear causal drivers, which give rise to falsifiable hypotheses that are open for empirical testing (Sabatier, 1999).

The major policy change model for Vietnam is based on the literature review in Chapter II and my own professional experiences as a public official working for a central policy agency in Vietnam (the Ministry of Education and Training). In particular, the model adopts the interactive stages and causal mechanism of the policy process articulated in the Policy-regime model created by Carter Wilson (2000) and is illuminated by the Focusing-event model proposed by Thomas Birkland (2006). In addition, the model borrows the policy concepts from the Punctuated-equilibrium theory (policy image) and Advocacy-coalition theory (political core values similar to deep core beliefs) and the categorizations of policy change articulated by Hogwood and Peters (1992). It takes into account the important policy contextual factors in developing countries which are emphasized by comparative government research, especially by the "Policy-elite" model (Grindle and Thomas, 1991) and integrates the regime characteristics of Vietnam as a developing, transitional and single-party country which are suggested by the "Technical-infeasibility" model on China policy process (Zhu, 2008). 
The proposed major policy change model for Vietnam in Figure 1 is expected to help policy analysts have better understanding of the "mysterious" policy phenomenon or "unexplainable" behaviors of the Vietnamese regime exposed to both inside and outside observers in policy reforms during Đổi Mới. It seeks to explain how and why a major policy reform initiative can be adopted or inhibited when the policy elites in Vietnam have to deal with both internal and external pressures in the transitional period of time. The model differs from other traditional political theories and models those related to power struggle, democratization, or revolution domains, by employing the languages of policy study to explain policy change process and outcomes in Vietnam.

The policy model starts with the variable of stressor in the first policy stage of the policy process. Following other popular policy process theories and models, the model in this study also emphasizes the role of stressors that can challenge the policy status quo and the existing dominant policy image, paving the way for major policy change. Change, however, does not occur automatically even when the regime has faced stressors. Stressors just play a role as a necessary catalyst for any major policy changes in Vietnam and makes changes more likely to happen.

Indeed, stressors may increase policy elites and makers' attention to policy problems or failures and encourage policy-oriented learning but they do not automatically bring about policy changes. To increase the likelihood of major policy change, a stressor must be perceived as a real challenge or crisis requiring policy reform. At this agenda setting stage, policy elites' predisposition to reform will be the main criteria in determining whether the government responds to the stressors or not. The leadership predisposition of policy elites in the CPV and government is important 
in every policy system but it is especially critical in the case of Vietnam due to the state-led and centralized nature of the single-party political system and the high level of autonomy vested in the policy elites.

In the face of stressors, the policy elites (Prime Minister, ministers, vice ministers, senior policy makers in central policy agencies) will defer to their ideological commitments, political priorities and institutional constraints to make their judgments. If the policy elites do not consider a stressor as a serious issue, even in the case of great pressures from external international institutions, they will use their authority and resources to ignore it or encourage resistance. As a result, nothing will happen, that will produce a policy maintenance outcome. If the stressor is considered a serious challenge to the socio-economic development strategies or legitimacy of the regime, Party's guiding resolutions and decisions will be produced to advance the alternative policy images into the agenda of the government or National Assembly for further deliberation and studies.

At the next stage, internal policy deliberation will involve representatives of various responsible and concerned bureaucratic agencies. Policy feedback, new information, and policy-oriented learning will be shared and included in the deliberation to produce policy change alternatives. These alternatives are filtered by the criteria of "technical feasibility" representing cost-effective calculation, the requirements and conditions for successful policy implementation (i.e., budget, organizational capacity, etc.), and the best way to realize political goals through the policy change. This stage takes place mostly within the state agencies and units of the National Assembly or government. It does not mean that the Party's committees of these agencies do not have any influence on the policy process and outcomes. They, 
however, only produce guidelines and direction to select the policy change alternatives that will be submitted to the higher level of the Party. Notably, if there is a significant change in the policy image at this stage, there will be a chance for innovative policy change alternative to be formulated and then advanced to the adoption stage. The significant change in policy image in turn depends on how the policy elites calculate between the need to maintain Socialist legacies and the demand for policy change. If no new policy image is produced and articulated, the policy outcome will only result in a policy linear succession.

To be officially adopted, the innovative policy change proposal characterized by new policy image will be submitted to the Party Central Committee and filtered one more time against the political criteria. At this stage, the leading role of the Politburo with the consultation of policy elites in the executive organizations is vital. Within the Central Party Committee and the Politburo, the collective and consensus decision-making model will be employed. This stage of the process may take a lot of time, even years, to produce a solution that can integrate most of the political preferences of key actors in the Party as well as in the government. No one in this process can dominate the policy outcomes without the consensus of the top political leaders in the Politburo and a popular agreement within the Party Central Committee.

If an innovative policy change proposal does not violate the guiding core values of the ruling regime while congruent with the contemporary political priorities, it will more likely produce a consensus within the Party. Such a policy change proposal, however, is rare because at the same time it must meet the requirement of congruence with the Party's core values and political priorities as well as the consensus among leaders in the Politburo and the government. If the innovative 
policy change proposal does not meet the test of this filtering process, the policy proposal may be delayed or a policy non-linear succession outcome may result. If it can meet both congruence and consensus criteria at the last stage of the policy process, a radical policy change can occur afterward.

To summarize this model, the necessary conditions for a radical/innovative policy change at the national level of Vietnam are the stressor and the predisposition by the policy elites to reform. These are the preconditions for an innovative policy change initiative to be advanced into the official agenda of the National Assembly and government. The sufficient conditions for an innovative policy change alternative to be formulated and then adopted are the significant change in the policy image of the policy elites and its political acceptability. The significant policy image change help create innovative policy change proposal while the congruence of the policy change proposal with the Party contemporary political priorities at a certain period of time leads to the consensus on the radical policy change within the Party and Government. For a radical policy change to be adopted, all four policy factors identified in the policy model need to be present during the policy change process in Vietnam.

\section{Generated propositions to validate the policy model}

The policy model developed and explained in the previous section of this chapter is grounded in the literature review on policy process theories and models and on the regime characteristics of Vietnam. Since the model is new, it is important to validate its usefulness and relevance in explaining the policy change process and outcome during Đổi Mới in Vietnam. From the model, (illustrated in Figure 1) I have generated four propositions that can assist us in assessing the viability and usefulness

of the model. For the purposes of this dissertation, the case studies from chapters $\mathrm{V}$ to 
VIII will be organized and examined in the way that helps to verify these propositions.

1. In the policy context of Vietnam, the stressors and Party's leadership predisposition to reform are the preconditions for a radical policy change innovative to be advanced into the agendas of the government and National Assembly.

2. Significant changes in the policy image of the regime elites are necessary for the formulation of innovative policy change alternative.

3. For a radical change to occur there must be a consensus on the contemporary political priorities within the regime that support the proposed innovative policy change.

4. Political judgments based on the core political values or on the political priority consensus of the ruling regime can predominate over the criteria of technical feasibility to produce or inhibit radical policy change in Vietnam. 


\section{Chapter IV: Research Design and Methodology to Validate the Proposed Model of Major Policy Change in Vietnam}

As the first step in validating the newly created major policy change model for Vietnam, four (4) selected policy change case studies in Vietnam will be conducted. In the selection of cases, I borrow the following indicators of policy change: (1) the issuance of new or proposed laws and regulations on a policy domain; (2) a change in the nature and substance of the laws and regulations being issued; (3) Change in procedures and in the interpretation and implementation of statutes and regulations (Birkland, 2006).

Two of these case studies involve radical change outcomes: the decision to sign the Bilateral Trade Agreement with the United States in 2000 along with the accession to World Trade Organization in 2006 and the radical legal change in the integrative Investment Law of 2005, which creates a level playing field for all types of enterprises. The other two case studies characterized by no radical change outcome are the cases of state-owned enterprise management policy and higher education policy on autonomy for higher education institutions. The main purpose of the case study analysis is to assess the value of the proposed policy model in this dissertation.

The first section of this chapter will explain the research design of the case studies and the reason for using the comparative and qualitative research design in this type of research. Second, I will describe the methods used to collect and code the data in the case studies. Third, I will explain how I analyze the data to validate the relevance and usefulness of the policy factors and causal flow which are the essence of my proposed policy change model. 


\section{Research design}

Since the main objective of the case studies is to validate the newly created major policy change model for Vietnam, the research design strategy is qualitative and comparative in nature. The subject of research is a new policy model and has never been addressed with certain sample cases. That is why the qualitative approach is a suitable approach for exploratory purpose. Also, the comparative method is appropriate for discovering the empirical relationships among variables, not as a method of measurement (Lijphart, 1971). The features of the comparative method make it useful for the task of building new theories or models or synthesizing existing theories (Ragin, 1987). In this dissertation, comparative studies are to provide evidence for the validation and development of a new policy model applied to Vietnam.

The selected cases in this study are critical cases that represent different ideal types of policy outcomes: radical change and non-radical change. The objective of the case studies is to examine if in the cases with similar policy outcomes, there is a general path traveled to reach the outcome. Notably, the case studies are centrally concerned with sequences and timing of events, with an eye toward turning points and path dependence (Ragin, 2004). Thus, in-depth case studies are used in this dissertation to assess the value of my proposed policy model by examining the existence or absence of the critical policy change factors in each of the cases as well as to verify the proposed causal flow of the policy change model. The empirical evidence revealed in the cases can consolidate or weaken the explanatory capacity of the policy factors/concepts and causal arguments of the proposed model. 
In particular, the case studies in this research use the theory-confirming and theory-infirming approach (Lijphart, 1971). That is, the case studies are used to gather the empirical evidence to evaluate the propositions I propose to validate the new model of major policy model for Vietnam. Substantively, the case studies will examine the role of the four policy factors identified in the policy model and their relationships in the policy change process and outcomes. If a case is of the theoryconfirming type, it strengthens the claim made in each of the propositions. But, assuming that the propositions are solidly based on a large number of cases, the demonstration that one more case fits does not strengthen it a great deal. Like-wise, theory-disconfirming case studies only weaken the generalizations marginally (George, 1997).

Notably, George \& Bennett (2005) identified several requirements that the comparative case method must meet to overcome criticisms. First, the investigator should clearly identify the "class" or "subclass" of events - of which a single case or a group of cases to be studied are an instance. In this dissertation, two cases are selected to represent radical policy change and the other two represent the absence of radical change. The criteria to select the radical change cases rely on the definition of radical/innovative policy change defined by Hogwood and Peters (1992) presented in Section 2 of Chapter III (see Table 4). Second, a well-defined research objective and an appropriate research strategy to achieve that objective should guide the selection and analysis of a single case or several cases within a class or subclass of the phenomenon under investigation. In this regard, the objective of the case study is to validate a proposed policy model and identify the limitations of the model based on the empirical evidence from the cases. Third, the case studies should employ well 
defined variables of theoretical framework for the purposes of explanation. The policy cases in this research employ the key policy concepts (both independent and dependent variables) and the causal mechanism of change embedded in the proposed policy model set forth in Figure 1 in Chapter III.

\section{The analysis framework for the case studies to validate the policy model}

The analysis framework of each case study is composed of the following sections:

\section{Introduction to the case}

The introduction of the case will include both substantive information about the policy domain and the institutional arrangements surrounding the policy domain with the following aspects:

- Policy issues/policy problems

- Existing policy framework

- Review on the timeline of key legal changes or policy decisions which are arranged chronologically

- Policy outcomes

Case analysis

The case analysis section will focus on examining the existence or absence of the policy factors, which are identified as the independent variables in the proposed policy model for Vietnam. It step by step identifies the evidence related to the stressor, leadership predisposition, policy image, and consensus on political priority and examines the role of these policy factors in different stages of the policy process with relevant outcomes. The evidence is also related to the logical flow identified by the proposed policy change model. It should be noted that in the cases without radical change, because no innovative/radical policy change proposal has been advanced and 
discussed, the factor of consensus on political priority is not examined. Each of the policy factors will be examined by answering important questions as following:

- Stressors:

- Was there any stressor for policy change in the case? If yes, explain the indicators of the stressor.

- What was the nature of the stressor: triggering new challenge, or consolidating an ongoing change in policy image or tipping the positive feedback?

- How did the Party and government perceive and articulate the stressor?

- What are the roles of the stressor in the stage of agenda setting, especially its relationship with the leadership predisposition to reform?

\section{- Leadership predisposition to reform}

- Did the policy elites in the Party and government fell the stressors and did they perceive it as a crisis or real challenges to the regime requiring for major policy response? What are the indicators of leadership predisposition?

- What were the main policy arguments and statements showing the change in the leadership predisposition to a given policy change initiative?

- How did leadership predisposition to reform advance the policy change initiative into the official agenda of the government and the National Assembly?

- Change in policy image of the policy elites and politicians

- How did the Party and the government identify and explain the policy problems uncovered by the stressors?

- How did the Party and the government articulate the solutions to the identified policy problems? 
- Was there any change in the perception of the policy elites in the way to realize political values and priorities through given policy change proposals? Or how did the Party and the government relate the policy problems and solutions to the general political goals and priorities of the regime?

- In the case with significant change in the policy image of the Party and the government, what make it change?

- In the case without significant change, what prohibited the change?

- Political acceptability - consensus on the temporary political priority

- In the case where innovative policy change alternative was formulated, discussed and submitted for adoption, is there any conflict within the regime in identifying the political priority of the Party at the time the policy change was deliberated?

- What were the main arguments regarding the congruence between the radical policy change alternatives attached to the new policy images and Party's core values and priorities at the examination time?

- Was the policy alternative congruent with Party's consensus on the temporary political priority? How do we identify the indicators of consensus?

In each of the above section, I will make use of two "within-case" analysis methods: the congruence and the process-tracking method. With the congruence method, I begin with the concepts and propositions embedded in the model and then attempt to assess the model's ability to explain or predict the policy change process and outcome in a particular case. With the method of process-tracking, I focus on analyzing data to elucidate the causal mechanisms including processes, events, actions, expectations and other intervening variables that link putative causes to observed effects. The main objective of process-tracking method is to determine 
whether the observed relationships among the variables in a case match those predicted by the propositions. Process tracking forces the investigator "to take equifinality into account, considering the possibility of mapping out one or more causal paths that are consistent with the same outcomes, checking for spuriousness, and pointing out variables that might be left out" (George \& Bennett, 2005). For example, in the two cases with radical policy change in this dissertation, process tracking helps discover if the factors inducing change are the same or not.

\section{Reflection on the case and the examination over the propositions}

Following the examination of the policy change factors, the last section of each case study is to develop the reflection. The evidence in each case will be related to the policy factors and causal flow of the policy change model to verify the relevance and explanatory capacity of the model in each study. This initial discussion will focus on examining the usefulness of the policy change factors and the causal arguments embedded in the model in explaining the policy change process and policy outcome in different policy areas in Vietnam during Đổi Mới.

\section{Conclusion: cross-case examination}

To analyze the data, this research uses the technique of "qualitative comparative analysis" in combination with the "within-case" methods. In the last chapter, the cross-case comparison method is used to diminish the small $\mathrm{N}$ problems by allowing inferences to be drawn from the maximum number of comparisons that can be made, in terms of the presence or absence of the causal factors of policy change, across the cases under analysis (Ragin, 2000). The goal is to verify the validity of the policy model across the case studies by showing the cross-case evidence supporting or disconfirming the arguments of the policy model. Table 5 is 
used to summarize the overall findings of the four cases in all policy stages and connecting the findings of policy factors to the policy outcomes of the cases.

Table 5: The relationships between policy factors and major policy outcomes in four cases

\begin{tabular}{|l|l|l|l|l|l|}
\hline $\begin{array}{c}\text { Case/causal } \\
\text { factor }\end{array}$ & Stressors & $\begin{array}{c}\text { Predisposition } \\
\text { to reform }\end{array}$ & $\begin{array}{c}\text { Change in } \\
\text { policy } \\
\text { image }\end{array}$ & $\begin{array}{c}\text { Congruence } \\
\text { with Party's } \\
\text { core values }\end{array}$ & $\begin{array}{c}\text { Major } \\
\text { policy } \\
\text { outcomes }\end{array}$ \\
\hline Case 1 & Yes or No? & Yes or No? & Yes or No? & Yes or No? & Yes \\
\hline Case 2 & Yes or No? & Yes or No? & Yes or No? & Yes or No? & Yes \\
\hline Case 3 & Yes or No? & Yes or No? & Yes or No? & Yes or No? & No \\
\hline Case 4 & Yes or No? & Yes or No? & Yes or No? & Yes or No? & No \\
\hline
\end{tabular}

\section{Data collection methods}

The case studies will employ the data collection methods of document review, and secondary information analysis. Document reviews will focus on the legal documents of both the Party and government (resolutions, laws, degrees, decision and directives); and secondary information analysis will focus on research papers, public officials' and leaders' policy statements, announcements, and interviews with press media; and other sources of information (see table 6).

Table 6: Different types of data and information sources

\begin{tabular}{|l|}
\hline \multicolumn{1}{|c|}{ Sources/types of collecting information } \\
\hline Party's resolutions/conclusion/socio-economic plan \\
\hline Government's decrees/resolutions/directives/decisions \\
\hline Ministerial directives/decisions/circulars \\
\hline Policy elites'statements \\
\hline Policy elites' interviews with the media \\
\hline Official reports, studies of public agencies \\
\hline Research and reports of third part \\
\hline Other sources \\
\hline
\end{tabular}

In order to collect and process the information and data, the independent variables are operationalized. Table 7 below summarizes the sources of information that are used to obtain evidence of each of the causal factors of change in the four 
cases. Some of the evidence may include statistical and analytic data; others will come from official government and party documents. To isolate the absence of presence of the policy factors, I also examine the statements from senior officials in public forums, media interviews and official addresses they have made.

Table 7: Operationalizing the policy change factors of the model

\begin{tabular}{|l|l|l|l|}
\hline \multicolumn{1}{|c|}{ Evidence } & \multicolumn{1}{|c|}{$\begin{array}{c}\text { Statistical and } \\
\text { analytic information }\end{array}$} & $\begin{array}{l}\text { Statements/announcements } \\
\text { of top leaders }\end{array}$ & \multicolumn{1}{|c|}{$\begin{array}{c}\text { Official and legal } \\
\text { documents }\end{array}$} \\
\hline Causal factors & $\begin{array}{l}\text { Negative data } \\
\text { regarding policy } \\
\text { anomaly, failure, risk, } \\
\text { and lost, etc. } \\
\text { documented in } \\
\text { domestic and } \\
\text { international reports } \\
\text { and research. }\end{array}$ & $\begin{array}{l}\text { Leaders admit the pressures } \\
\text { and challenges in statements, } \\
\text { interviews or speeches. }\end{array}$ & $\begin{array}{l}\text { Stressor admittance } \\
\text { documented in official } \\
\text { documents of Party or } \\
\text { government. }\end{array}$ \\
\hline $\begin{array}{l}\text { Predisposition } \\
\text { to reform }\end{array}$ & $\begin{array}{l}\text { Statements and arguments } \\
\text { from official leaders in the } \\
\text { central government and the } \\
\text { Party expressing the need for } \\
\text { policy change. }\end{array}$ & $\begin{array}{l}\text { Guidelines and directions } \\
\text { documented in official } \\
\text { documents of Party or } \\
\text { government regarding the } \\
\text { demand for policy change. }\end{array}$ \\
\hline $\begin{array}{l}\text { Change in } \\
\text { policy image }\end{array}$ & $\begin{array}{l}\text { New policy forums } \\
\text { created and opened } \\
\text { for policy } \\
\text { deliberation and } \\
\text { evaluation. }\end{array}$ & $\begin{array}{l}\text { about policy problems, policy } \\
\text { evaluation and the solutions } \\
\text { to change, etc. }\end{array}$ & $\begin{array}{l}\text { New policy goals and } \\
\text { paradigms regarding the } \\
\text { best way to realize } \\
\text { political goals and values } \\
\text { documented by different } \\
\text { agencies. }\end{array}$ \\
\hline $\begin{array}{l}\text { Congruence } \\
\text { with Party's } \\
\text { political priority }\end{array}$ & $\begin{array}{l}\text { Top or senior leaders' } \\
\text { interviews or statements } \\
\text { clarifying the rationales of } \\
\text { major change. }\end{array}$ & $\begin{array}{l}\text { Party } \\
\text { resolutions/decisions } \\
\text { regarding the consensus } \\
\text { on political priorities and } \\
\text { Party's strategies. }\end{array}$ \\
\hline
\end{tabular}




\section{Chapter V: A Case of Incremental Policy Change in Institutional Autonomy for Higher Education Institutions in Vietnam}

This dissertation relies on several policy case studies to examine how well the new policy change model proposed in Chapter III explains the policy change process and outcomes in different policy areas during the Renovation - Đổi Mới process in Vietnam. The policy cases are expected to provide the empirical evidence to verify the propositions generated from the model or at least to identify the extent to which the causal mechanism of policy change provided in the proposed model explain the policy outcomes in each case.

This chapter focuses on higher education policy of Vietnam to explore an example where no significant policy change has occurred despite several decades of strong and persistent pressure for reform. The results from the case studies allow us to understand why and how there has been no substantive reform. We can then compare to the cases that have experienced "significant reform". The case study is organized into five main sections as following.

The first section provides an introduction to the higher education system of Vietnam to identify its key indicators, challenges and policy changes during Đổi Mới. This section provides the reader with an overall understanding of the Vietnamese higher education system including: (1) The capacity and expansion of the Vietnamese higher education system; (2) The education quality of the system; (3) The incremental policy changes in state management in higher education; and (4) The Vietnamese governmental policy on institutional autonomy for higher education institutions. The second section will step by step employ the causal policy factors articulated in the 
proposed major policy change model to explore their applicability to explain policy change outcomes in higher education in Vietnam over the past two decades. These factors include: stressors to higher education policy reform, leadership predisposition to reform, and policy image of policy elites. Notably, because no innovative policy change alternative in terms of institutional autonomy has been formulated and submitted to the Party Central Committee for approval, this case will not examine the factor of Party's consensus on political priorities. Section three examines the role of other policy change factors in the policy process that might not be adequately captured by the policy change model proposed in Chapter III including policy entrepreneur and advocacy group. Finally, section four will provide some conclusions, especially with respect to the explanatory power of the proposed policy change model in this higher education policy domain.

\section{Introduction to the Vietnamese higher education system: indicators, challenges and policy change during Đổi Mới}

Over the past years, an increasing amount of research has been conducted on the Vietnamese higher education system and government policy in response to the perceived challenges and problems (Hayden \& Lam, 2007; Le, 2008; Harvard Kennedy School of Government, 2008 \&2011; Tran, 2009; Ho \& Berg, 2010). In this section, I will review this body of research to provide an overall picture of the higher education system in Vietnam. The review also incorporates the most updated data collected from the statistical reports produced by the Ministry of Education and Training of Vietnam. This review is to provide the context for my later discussion and analysis of the policy process and outcomes in this sector over the past two decades in Vietnam. 
As part of my background review, I will first provide some key quantitative and qualitative indicators characterizing the Vietnamese higher education system. This will be followed by a summary of the key challenges and problems faced by the system over the past two decades since Vietnam accelerated its economic reforms in the early of 1990s. Third, I will review the policy change process by examining key policy outcomes and the respective timeline of the policy changes. Finally, I will draw some important conclusions about the lack of radical policy change in giving substantive institutional autonomy for higher education institutions, even though the government has been rhetorically announcing its intention to reform.

\section{Government objectives of higher education in Vietnam}

The overarching goals of higher education have been articulated in a variety of legal documents of Vietnam, yet the two laws: Education Law of 2005 and Higher Education Law of 2012 are the most important documents which identify these goals. The Education Law of 2005 states that the general goal of education at all levels is to "educate the Vietnamese people in acquiring comprehensive development including

morality, knowledge, good health, professional skill; and in being loyal to the ideal of national independence and Socialism for the sake of the construction and defense of the nation" (Article 2, Vietnam Education Law, 2005). For higher education in particular, according to the Law, the goals are to "educate learners in acquiring political and moral competencies and public spirit, in acquiring knowledge and practical skills relevant to the different educational levels, and in acquiring good health, thereby meeting the needs of construction and defense of the nation" (Article 39, Vietnam Education Law, 2005). 
In the newly ratified Higher Education Law of 2012, the goals of higher education are quite similar to those of the Education Law of 2005 (see Article 5 of the Higher Education Law of 2012). The only difference is the order of the goals. In the Higher Education Law of 2012, the goals of developing human resources, improving literacy, training talents, conducting scientific and technological research and producing new knowledge for the sake of economic development, national security and international integration are prior to the goals of educating learners in acquiring political and moral competencies and public spirit. That means there is a change in the order between the goal for "expertise" - "Hồng"; and "political competence" "Chuyên". It should also be noted that the Education Law of 2005 defines the Vietnamese education system as a socialist education system founded on MarxismLeninism and Ho Chi Minh Thought while this principle has not been repeated in the new Higher Education Law of 2012. However, Article 3 of Higher Education Law 2012 asserts that the organization and operation of higher education institutions is still subjected to Education Law 2005 suggesting that Marxism-Leninism and Ho Chi Minh Thought are still applicable to higher education administration.

\section{The capacity and expansion of the Vietnamese higher education system}

Higher education institutions in Vietnam are differentiated and classified into four different sub-types including: two-year colleges, four-year universities/academies, regional or national universities, and research institutes permitted to organize doctoral programs (Vietnam Higher Education Law, 2012). In terms of ownership, there are three types of institutions: public, private and foreigninvested institutions, which offer Associate, Bachelors, Masters and Doctoral degrees (Vietnam Education Law, 2005; Vietnam Higher Education Law, 2012). Besides 
regular full-time training, there is a parallel system called "continuing education" that provides in-service and distance learning programs. This type of education program provides opportunities of lifelong learning for people while they are working to improve their knowledge, and skills required for a changing labor market and society (Ho \& Berg, 2010). In 2011, about 8\% students in two-year college programs and $32 \%$ students in four-year university programs were participating in continuing education programs nationwide (Department of Information Technology (DIT) MOET, 2011).

Along with the rapid economic development, the Vietnamese higher education system has rapidly expanded since the early of 1990s. In 1987, one year after Vietnam started its Đổi Mới Program; there were only 101 four-year universities and junior colleges (Tran, 2009). The total number of higher education institutions increased to 386 in 2011, almost 3.8 times the number in 1987 and 2.5 times the number in 2000 (DIT, 2011). In 1988, the first private university was authorized to operate in the Vietnam. Since then, the number of private institutions has increased rapidly, reaching 80 in $2011,20 \%$ of the total number of higher education institutions. Regarding the college and university network, by 2009, 40 out of 63 provinces in Vietnam have at least one four-year university $(63 \%)$ and 62 out of 63 provinces had at least one twoyear college (95\%) (MOET, 2009). Notably, the number of new universities in Hanoi and Ho Chi Minh City accounts for $43 \%$ of newly established or upgraded universities across the country over the past years (Ho \& Berg, 2010).

In 1987, Vietnam only had 133,136 tertiary students at all levels. After more than two decades, the total number of student in colleges and universities at all levels has increased 16.2 times to 2,162,106 in 2011 (DIT, 2011). However, the proportion 
of students in private institutions has counted for only $13 \%$ and $20 \%$ at the two-year and four-year programs, respectively in 2011 (DIT, 2011). In total, the proportion of students in private institutions (both two-year and four-year) has increased slightly, from $12 \%$ in 2000 to $15 \%$ in 2011 . That percentage increases falls significantly short of the target set by the government to increase the number of students in private institutions to $40 \%$ by 2015 (Prime Minister's Resolution No. 14, 2005).

In 1997 , Vietnam had only 80 tertiary students per 10 thousand population compared to 166.5 in 2006, 195 in 2009, and 240 in 2011 (MOET, 2009; DIT, 2011). This number is still small compared to the number of other countries calculated in 2005: 347 in Thailand, 407 in Chile, 316 in Japan, 359 in France, and 674 in South Korea (MOET, 2009). The number of 240 tertiary students per 10,000 falls significantly short of the Vietnamese higher education targets set out by the Education Reform Agenda in 2005 to increase the enrolment rate to 450 students per 10,000 populations by 2020 .

In 2009, all types of higher education institutions (both junior colleges and four-year universities) in Vietnam had places for only 400,000 of the 1.2 million candidates who took the annual national university entrance exams (Nuffic, 2010). This accounted for approximately 30\% of the total high school graduates. From 2000 to 2008, post-graduate institutions have provided training for only an average of 650 doctorates per year. In 2009, the post-graduate programs across Vietnam recruited an increasing number of 2,504 doctorate students and 30,638 master level students. These numbers fall short of the target set by the government to have 20,000 Ph.D.trained higher education instructional staff by 2020. To manage university admission, the Ministry of Education and Training (MOET) has established two universal 
requirements: (1) national standardized entrance examinations and examination schedules, (2) minimum scores for admission to all public and private colleges. Based on these requirements, institutions determine the admission and recruitment quota annually. In short, the above indexes indicate that the demand for higher education opportunities exceed the existing capacity of educational institutions, even though the system has been expanded dramatically since 1990s.

\section{The quality of the higher education system}

Despite impressive expansion, the higher education system of Vietnam suffers from various quality challenges. Indeed, according to an official report from MOET in 2009 , the development of higher education has been unable to provide the trained human resources needed to support the industrialization process, to keep pace with modernization, to facilitate international integration and to meet the learning needs of the people. The U.S.-Vietnam Education Task Force Final Report (September, 2009) concluded that Vietnam is under the "pressing need for significant modernization of its higher educational system, including fundamental changes in governance, institutional autonomy, financing and administration, faculty hiring, promotion and salary structure, as well as in curricula and the modalities of teaching, evaluation, and research" (Vietnam-US Higher Education Conference, 2009, pp. 3).

Especially, Vietnamese universities are incapable of producing the educated workforce that Vietnam's economy and society require in the economic development process. Surveys conducted by government-linked associations have found that as many as 50 percent of the Vietnamese university graduates are unable to find jobs in their areas of specialization, revealing a major disconnect between the classroom and the demands of the labor market (Harvard Kennedy School of Government, 2008). A 
good example that illustrates the weakness of the higher education system is the case of Intel Corporation when it established the largest chip fabrication plant in the world in Ho Chi Minh City in 2006. Among the 2,000 students selected from the top technical universities across Vietnam, only $6 \%$ met the minimum requirements of the company. As a result, Intel has decided to send three students cohorts to Portland State University to obtain their degree in the U.S. with the promise of employment upon their return to Vietnam.

Although the number of students enrolled in higher education institutions in Vietnam has increased 16.7 times from 1990 to 2011, the total number of teaching staffs at all higher education institutions has increased only 3.4 times (DIT, 2011). This disparity has caused the average student/faculty ratio to increase to $31: 1$ for twoyear colleges and 28:1 for four-year universities. Currently, only $10.6 \%$ of Vietnamese university teaching staff holds doctoral degrees and $41 \%$ hold Master degrees (DIT, 2011). This compares unfavorably with most other countries in the region. For example, $83 \%$ of the higher education teaching staff in South Korea held $\mathrm{PhD}$ degrees in 2006 (Kim, 2008). In addition to the inadequate number of university instructors, low salary and poor working conditions have not provided adequate incentive for teaching staff to focus on teaching quality and scientific research.

In terms of research productivity of higher education institutions, according to a study of peer-refereed publications (PRIP) per one million people in 11 East and Southeast Asian countries, Singapore leads the region, with a 30 times higher publication rate than Thailand, 170 times higher than Vietnam, and 530 times higher than Indonesia (Pham, 2010). Also in this study, compared to Thailand, Vietnam's total PRIP output has been smaller than that of a single university in Thailand, such as 
Chulalongkorn or Mahidol. Moreover, domestic co-authors account for nearly $80 \%$ of PRIPs from Thailand compared to only 37\% from Vietnam; and in Thailand, $95 \%$ of the PRIPs are produced at universities compared to only 55\% in Vietnam (Pham, 2010).

Part of the concern about the inadequacy of Vietnam's higher education system is driven by the forces of globalization, which have accelerated the need for a highly trained and flexible work force in the labor markets of all economic sectors. One research has identified the following five specific challenges that globalization is posing to Vietnam's higher education system: the comparability of quality and standards; the multi-nationalization of higher education; the problem of brain drain; the problem of intellectual property; and maintaining a university as a learning organization (Luu, 2006). These challenges have become even more visible since Vietnam joined the World Trade Organization in 2006. In the international integration process, Vietnam's higher education system has been increasingly exposed to international competition and the risks of being left behind in the race with other countries in the region such as China, South Korea, Singapore, Thailand and Malaysia.

To summarize, higher education in Vietnam continues to face the challenges both in the quality and the quantity of its offerings. The Vietnamese Party's resolutions and government's decrees and directives have acknowledged the need for change, but as the following section will document, actual changes have been more symbolic and incremental than real and radical. 


\section{Incremental governance changes in higher education}

Following economic and political transformation, the Communist Party of Vietnam has been aware of the demand for education reform in general and for higher education reform in particular. The propensity for reform in higher education can be traced back to the Party's Guiding Resolution No. 4 of the VII National Party Congress in 1993 and the Guiding Resolution No 2 of the VIII National Party Congress in 1996 in which education in general and higher education in particular were considered as the driving forces for socio-economic development in the transitional period of the country. In 2005, the Prime Minister called for a "fundamental and comprehensive" renovation in the higher education system in order to achieve remarkable changes in quality, efficiency, and structure that would meet the national demand for modernization, industrialization and international integration (Prime Minister's Resolution No. 14, 2005). Accordingly, the goals set forth in Resolution No. 14 for achievement by 2020 were for Vietnam's higher education system to develop to an advanced level of performance within the region and the world; to be highly competitive; and to be compatible with a market economy that is guided by the Vietnamese Socialist ideology. Resulting from this resolution and the Higher Education Reform Agenda initiated by MOET in 2005, a number of actions, policy pronouncements and operational changes have been advanced in the form of governmental decrees, resolutions, circulars that have affected curriculum, student admission, financial management and the quality of equipment and facilities. In general, incremental governance changes have taken place in the following specific areas:

1. Organizational structure and network planning of the higher education system 
2. Training contents, methods and procedures

3. Personnel management in higher education institutions including instructional staff recruiting, training and compensating mechanism

4. Student admission and quota setting procedures

5. Financial usage mechanism and resource mobilization within the institutions

6. State administration and management in higher education

These incremental policy changes in higher education state management have been embedded in a number of government's decrees, decisions and directives which are then synthesized in the newly-ratified Higher Education Law of 2012 (See table 8 and 9 for details). The goals have been clear: to modernize higher education and improve its quality to meet the demand for high-skilled labor force and to bridge the development gap between Vietnam's higher education and those of regional and international countries. However, policy-makers have been mostly focused on solution-based and incremental policy changes instead of radical change in policy philosophy and in regulatory framework that can provide innovative state management in higher education. Especially, there has been a lack of innovative policy on institutional autonomy for higher education institutions as presented in the following section.

\section{The Vietnamese governmental policy on autonomy for higher education}

\section{institutions}

Despite considerable operational and administrative changes in the state management in higher education of Vietnam, academic institutions remain subject to a highly centralized system of control (Hayden \& Lam, 2007; Harvard Kennedy School, 2008). A variety of key areas related to administrative autonomy and 
academic freedom are rigorously regulated by the government represented by the Ministry of Education and Training (MOET) and 12 other line ministries (Hayden \& Lam, 2007). Evidence of centralization and lack of autonomy include the following practices:

- All universities use the national MOET entrance examination to select and recruit students.

- The Ministry of Education and Training creates the curriculum framework (recently replaced by the national standards) for all education programs, including required key contents, course structure, time frame, and ratio of theory versus practice components. Adhering to the established curriculum framework/national standards, each university builds a detailed curriculum and composes textbooks.

- Approval from MOET is required for most of the universities to open new education programs except for the two National Universities. New education programs must be under the approved list of subjects set by the government.

- The Department of Testing and Accreditation established in 2004 is under direct control of MOET. No independent accrediting agency has been established yet.

- The newly established Association of University and College Presidents does not have actual influence on policy making process in higher education. 
- Except for the two National Universities, all public universities are dependent on MOET and other line ministries for a large part of their budgets.

- MOET and other line ministries continue to appoint and promote all public university presidents.

- Public university teacher rankings and salaries are regulated by the government's salary system applying to all public employees.

- All higher education institutions need to report their administrative activities and performance to MOET and other line ministries when required.

In the face of the low quality and backwardness of the higher education system, many people inside and outside government have recognized the adverse impacts of the centralized management policy on higher education, both in terms of university quality and capacity (Luu, 2006; Hayden \& Lam, 2007; Harvard Kennedy School, 2008; Nguyen, Oliver \& Priddy, 2009; Brooks, 2010; Vietnam - America Partnerships Conference, 2009, etc.). In particular, Luu (2006) argued that the lack of autonomy and accountability in institutional governance causes difficulties in enhancing educational quality and competitiveness of the Vietnamese universities, making them unable to obtain the ranks comparable to other regional or international universities. Nguyen et al, (2009) asserted that MOET strictly controls most higher education institutions' curriculum and personnel decisions, thus universities have little autonomy and freedom to operate according to their own standards of quality. Pham (2010) pointed out that limited institutional autonomy inhibits the taking of initiatives and proactive attitudes by higher education administrators and creates red tape and 
bureaucratic rules in the universities, hindering the development of an entrepreneurial spirit in institutional governance.

In fact, the Vietnamese Communist Party and government have recognized the need to give more autonomy for higher education institutions in response to the inadequate management capacities of state agencies, the shortage of government budget for higher education, and the need for international integration. Many Party and government documents refer to the need for delegation of authority to individual institutions. However, there is still a big gap between intention and actual commitments and concrete policies due to the intense conflicts between the reforming and conservative views over the role of state and institutions in the administration of higher education. Different views create a policy paradox that on the one hand the Party and the government have made policies arguing for expanded autonomy for higher education institutions; while on the other hand, the Party and the government have promulgated various rules and regulations that consolidate its controls over the institutions. Tables 8 and 9 below will present government policies and practices that support each of the two views.

Table 8: Major policies and practices that support decentralization in higher education of Vietnam

\begin{tabular}{|l|l|l|l|l|}
\hline No & \multicolumn{1}{|c|}{$\begin{array}{c}\text { Name of the } \\
\text { documents }\end{array}$} & \multicolumn{1}{|c|}{ Date } & $\begin{array}{l}\text { Contents related to institutional } \\
\text { autonomy in the documents }\end{array}$ & $\begin{array}{l}\text { Policy implication for } \\
\text { institutional } \\
\text { autonomy }\end{array}$ \\
\hline 1 & Resolution No. 4 & $\begin{array}{l}4^{\text {th }} \text { Plenum } \\
\text { of the VII } \\
\text { National } \\
\text { Party } \\
\text { Congress in } \\
1993\end{array}$ & $\begin{array}{l}\text { Point to the need to maintain state } \\
\text { management of the Ministry of } \\
\text { Education and Training; in the } \\
\text { meantime increase the autonomy of } \\
\text { educational institutions, especially } \\
\text { for the universities and expand } \\
\text { democracy within the schools. }\end{array}$ & $\begin{array}{l}\text { For the first time, an } \\
\text { important legal } \\
\text { document mentions the } \\
\text { need for greater } \\
\text { university autonomy. }\end{array}$ \\
\hline 2 & $\begin{array}{l}\text { Prime Minister's } \\
\text { Decision No. 240 }\end{array}$ & 1993 & $\begin{array}{l}\text { Set forth the guidelines for the } \\
\text { establishment and operation of } \\
\text { private universities, including the } \\
\text { right to establish a governing board, } \\
\text { financial autonomy, and the right to } \\
\text { recruit faculty, staff and a president. }\end{array}$ & $\begin{array}{l}\text { Allows the } \\
\text { establishment of private } \\
\text { universities with } \\
\text { institutional autonomy } \\
\text { in some administrative } \\
\text { aspects but still under }\end{array}$ \\
\hline
\end{tabular}




\begin{tabular}{|c|c|c|c|c|}
\hline & & & & $\begin{array}{l}\text { strict control of the } \\
\text { government }\end{array}$ \\
\hline No & $\begin{array}{l}\text { Name of the } \\
\text { documents }\end{array}$ & Date & $\begin{array}{l}\text { Contents related to institutional } \\
\text { autonomy in the documents }\end{array}$ & $\begin{array}{l}\text { Policy implication for } \\
\text { institutional } \\
\text { autonomy }\end{array}$ \\
\hline 3 & $\begin{array}{l}\text { Prime Minister's } \\
\text { Decision No. } 477 \\
\text { on the Charter of } \\
\text { National } \\
\text { University in } \\
\text { Hanoi }\end{array}$ & 1994 & $\begin{array}{l}\text { Set forth the establishment of the } \\
\text { National University in Hanoi, as a } \\
\text { key institution, which was granted } \\
\text { more institutional rights compared } \\
\text { to other institutions. }\end{array}$ & $\begin{array}{l}\text { Since } 1994, \text { the } \\
\text { government has } \\
\text { allowed for national, } \\
\text { regional and some } \\
\text { special universities } \\
\text { such as Vietnam - } \\
\text { German University to } \\
\text { have more institutional } \\
\text { autonomy. }\end{array}$ \\
\hline 4 & $\begin{array}{l}\text { Resolution No. } 2 \\
\text { on Development } \\
\text { Strategy for } \\
\text { Education and } \\
\text { Training in the } \\
\text { Period of } \\
\text { Industrialization } \\
\text { and } \\
\text { Modernization } \\
\text { till } 2000\end{array}$ & $\begin{array}{l}\text { The } 2^{\text {nd }} \\
\text { Plenum of } \\
\text { the VIII } \\
\text { Party } \\
\text { National } \\
\text { Congress in } \\
1996\end{array}$ & $\begin{array}{l}\text { Emphasize the weaknesses and } \\
\text { challenges of the whole education } \\
\text { system and the demand for } \\
\text { renovation to meet the demand of } \\
\text { economic development. }\end{array}$ & $\begin{array}{l}\text { The resolution } \\
\text { recognizes the need to } \\
\text { clarify and increase the } \\
\text { autonomy of } \\
\text { institutions. However, } \\
\text { the idea of institutional } \\
\text { autonomy is still very } \\
\text { abstract and is } \\
\text { mentioned in only one } \\
\text { sentence. }\end{array}$ \\
\hline 5 & $\begin{array}{l}\text { Government } \\
\text { Resolution No. } \\
90 \text { on the } \\
\text { Direction and } \\
\text { Guideline for } \\
\text { Socialization of } \\
\text { Education, } \\
\text { Healthcare and } \\
\text { Culture Activities }\end{array}$ & In 1997 & $\begin{array}{l}\text { (1) Delegate the financial burden of } \\
\text { the public budget to the people and } \\
\text { private sector; (2) Allow } \\
\text { educational institutions to charge } \\
\text { higher tuition to increase their } \\
\text { income; (3) Encourage private and } \\
\text { business sectors to invest in public } \\
\text { services including education; (4) } \\
\text { Provide institutional autonomy for } \\
\text { universities to raise the income } \\
\text { from the collaboration with } \\
\text { enterprises; (5) Encourage } \\
\text { institutions to develop international } \\
\text { partnerships to exploit external } \\
\text { resources for public services }\end{array}$ & $\begin{array}{l}\text { Due to the lack of } \\
\text { resources, the } \\
\text { government has to } \\
\text { allow more autonomy } \\
\text { for institutions in } \\
\text { seeking financial } \\
\text { resources, sharing the } \\
\text { financial burden with } \\
\text { the students and their } \\
\text { families, and promoting } \\
\text { international } \\
\text { cooperation that can } \\
\text { generate additional } \\
\text { external resources }\end{array}$ \\
\hline 6 & $\begin{array}{l}\text { Conclusion No. } \\
\text { 14-KL/TW of the } \\
\text { Politburo and } \\
\text { Party Central } \\
\text { Committee on the } \\
\text { Development } \\
\text { Direction of } \\
\text { Education and } \\
\text { Training, Science } \\
\text { and Technology } \\
\text { till } 2010\end{array}$ & $\begin{array}{l}\text { In } 2002 \text {, at } \\
\text { the } 6^{\text {th }} \\
\text { Meeting of } \\
\text { the IX } \\
\text { National } \\
\text { Party } \\
\text { Congress }\end{array}$ & $\begin{array}{l}\text { Strongly emphasize the demand for } \\
\text { innovation in state management in } \\
\text { education, including the issue of } \\
\text { institutional autonomy }\end{array}$ & $\begin{array}{l}\text { This is the first time, } \\
\text { the Party Central } \\
\text { Committee and } \\
\text { Politburo specifically } \\
\text { pointed to the need to } \\
\text { delegate more } \\
\text { administrative } \\
\text { autonomy to } \\
\text { educational institutions, } \\
\text { especially universities, } \\
\text { and the responsibility } \\
\text { of local governments } \\
\text { (the People's } \\
\text { Committees) in state } \\
\text { management in } \\
\text { education }\end{array}$ \\
\hline 7 & $\begin{array}{l}\text { Prime Minister } \\
\text { Resolution No. }\end{array}$ & In 2005 & $\begin{array}{l}\text { State management is one of the } \\
\text { reform solutions that includes: (1) }\end{array}$ & $\begin{array}{l}\text { This document has } \\
\text { been considered as the }\end{array}$ \\
\hline
\end{tabular}




\begin{tabular}{|c|c|c|c|c|}
\hline & $\begin{array}{l}\text { 14/2005/NQ-CP } \\
\text { on "Fundamental } \\
\text { and } \\
\text { Comprehensive } \\
\text { Renovation of } \\
\text { Vietnam Higher } \\
\text { Education for } \\
\text { 2006-2020" and } \\
\text { the Higher } \\
\text { Education } \\
\text { Reform Agenda } \\
\text { (HERA) of the } \\
\text { Ministry of } \\
\text { Education and } \\
\text { Training }\end{array}$ & & $\begin{array}{l}\text { conferring on public higher } \\
\text { education institutions } \\
\text { administrative autonomy in their } \\
\text { operations, giving them the right to } \\
\text { decide and be responsible for } \\
\text { training, research, human resource } \\
\text { management and budget planning; } \\
\text { (2) Abolishing line ministry } \\
\text { supervision of universities in the } \\
\text { meantime ensuring the right of the } \\
\text { community and social } \\
\text { organizations, especially } \\
\text { professional associations, to } \\
\text { oversee the quality of higher } \\
\text { education; (3) developing the } \\
\text { accrediting system for quality } \\
\text { assurance; (4) Accelerating the } \\
\text { State's stewardship role in } \\
\text { monitoring and inspecting the } \\
\text { overall structure and scale of higher } \\
\text { education; and (5) Building higher } \\
\text { education law. }\end{array}$ & $\begin{array}{l}\text { most innovative one in } \\
\text { higher education. The } \\
\text { key idea is to reinforce } \\
\text { the delegation of } \\
\text { authority from the state } \\
\text { to the higher education } \\
\text { institutions and to } \\
\text { develop a new kind of } \\
\text { relationship between } \\
\text { state and higher } \\
\text { education (Dao \& } \\
\text { Hayden, } 2010 \text { p. } 13 \text { ). } \\
\text { However, all of these } \\
\text { intentions have not } \\
\text { been realized by } \\
\text { concrete regulatory } \\
\text { framework. Also, this is } \\
\text { not a Party resolution }\end{array}$ \\
\hline No & $\begin{array}{l}\text { Name of the } \\
\text { documents }\end{array}$ & Date & $\begin{array}{l}\text { Contents related to institutional } \\
\text { autonomy in the documents }\end{array}$ & $\begin{array}{c}\text { Policy implication for } \\
\text { institutional } \\
\text { autonomy }\end{array}$ \\
\hline 8 & $\begin{array}{l}\text { Amended } \\
\text { Education Law }\end{array}$ & In 2005 & $\begin{array}{l}\text { Following the Education Law in } \\
\text { 1998, the Amended Education Law } \\
\text { in } 2005 \text { has a separate article (No. } \\
\text { 60) to regulate the rights and } \\
\text { accountability of vocational } \\
\text { schools, junior colleges and four- } \\
\text { year universities. Institutions have } \\
\text { the rights to: (1) design the } \\
\text { curriculum, textbooks and teaching } \\
\text { plans for approved academic } \\
\text { programs; (2) identify student } \\
\text { enrolment numbers, conduct the } \\
\text { entrance exam, validate student } \\
\text { graduation and offer degrees; ( } 3 \text { ) } \\
\text { design administrative structures, } \\
\text { recruit, compensate and manage } \\
\text { faculty and staff; (4) mobilize and } \\
\text { use resources; (5) cooperate with } \\
\text { foreign economic, education and } \\
\text { research organizations according to } \\
\text { the state laws. }\end{array}$ & $\begin{array}{l}\text { However, these rights } \\
\text { are conditional and too } \\
\text { general to be } \\
\text { implemented. } \\
\text { Moreover, critical } \\
\text { rights of admission } \\
\text { method, opening new } \\
\text { program, developing } \\
\text { curriculum, appointing } \\
\text { president, establishing } \\
\text { accrediting agency } \\
\text { were not assigned in } \\
\text { this law. }\end{array}$ \\
\hline 9 & $\begin{array}{l}\text { Government's } \\
\text { Resolution No. } 5 \\
\text { reinforces the } \\
\text { Resolution No. } \\
90 \text { in } 1997\end{array}$ & In 2005 & $\begin{array}{l}\text { Reinforce the need for socialization } \\
\text { of public services including } \\
\text { education and healthcare, putting } \\
\text { forward the mechanisms to: (1) } \\
\text { increase the financial contribution } \\
\text { by individuals, private enterprises } \\
\text { and social partners in delivering } \\
\text { public services; (2) Encourage self- } \\
\text { financing of institutions in their } \\
\text { operation; and (3) transferring } \\
\text { semi-public schools to private ones, } \\
\text { allowing for for-profit education }\end{array}$ & $\begin{array}{l}\text { The word } \\
\text { "socialization" is used } \\
\text { by the government to } \\
\text { avoid the words } \\
\text { "privatization" or } \\
\text { "equitization". The } \\
\text { policy implication here } \\
\text { is the change in policy } \\
\text { image of the role of } \\
\text { public and private } \\
\text { actors in delivering } \\
\text { education and health }\end{array}$ \\
\hline
\end{tabular}




\begin{tabular}{|c|c|c|c|c|}
\hline & & & activities. & $\begin{array}{l}\text { services. In the past, } \\
\text { these services were } \\
\text { taken for granted as the } \\
\text { sole responsibility of } \\
\text { the state. }\end{array}$ \\
\hline No & $\begin{array}{l}\text { Name of the } \\
\text { documents }\end{array}$ & Date & $\begin{array}{l}\text { Contents related to institutional } \\
\text { autonomy in the documents }\end{array}$ & $\begin{array}{c}\text { Policy implication for } \\
\text { institutional } \\
\text { autonomy }\end{array}$ \\
\hline 10 & $\begin{array}{l}\text { Joint Circular on } \\
\text { Instruction for } \\
\text { Implementing } \\
\text { Autonomous } \\
\text { Right and } \\
\text { Accountability of } \\
\text { Public Education } \\
\text { and Training } \\
\text { Institutions (No. } \\
\text { 07/2009/TTLT- } \\
\text { BGDDT-BNV) }\end{array}$ & $\begin{array}{l}\text { Signed in } \\
2009 \text { by } \\
\text { Minister of } \\
\text { Home } \\
\text { Affairs, } \\
\text { and } \\
\text { Minister of } \\
\text { Education } \\
\text { and } \\
\text { Training }\end{array}$ & $\begin{array}{l}\text { Provide instruction concerning the } \\
\text { implementation of autonomy and } \\
\text { accountability in the following } \\
\text { administrative areas: designing and } \\
\text { implementing operational plans; } \\
\text { establishing joint-ventures with } \\
\text { other organizations; promoting } \\
\text { international cooperation; } \\
\text { organizing institutional structures; } \\
\text { managing human resources } \\
\text { (recruitment and promotion and } \\
\text { compensation). }\end{array}$ & $\begin{array}{l}\text { The regulations in this } \\
\text { Circular mostly focus } \\
\text { on the organizational } \\
\text { issues realizing the } \\
\text { rights of institutions in } \\
\text { human resource } \\
\text { management, daily } \\
\text { operation, and business } \\
\text { activities. They are, } \\
\text { however, very general } \\
\text { and are subject to other } \\
\text { rules and laws. }\end{array}$ \\
\hline 11 & $\begin{array}{l}\text { Resolution No. } \\
\text { 05-NQ/BCSD on } \\
\text { Innovation in } \\
\text { Higher Education } \\
\text { Management in } \\
\text { the Period 2010- } \\
2012\end{array}$ & $\begin{array}{l}\text { Issued on } \\
\text { January } 6 \text {, } \\
2010 \text { by the } \\
\text { Party } \\
\text { Committee } \\
\text { of the } \\
\text { Ministry of } \\
\text { Education } \\
\text { and } \\
\text { Training }\end{array}$ & $\begin{array}{l}\text { Emphasize the need for } \\
\text { decentralization and autonomy in } \\
\text { higher education clarifying the } \\
\text { responsibilities of the Ministry of } \\
\text { Education and Training, other line } \\
\text { ministries and provincial People's } \\
\text { Committee. It also points to the } \\
\text { need to encourage the institutional } \\
\text { autonomy and accountability, and } \\
\text { internal assurance and self-control } \\
\text { especially in implementing } \\
\text { institutional missions, organizing } \\
\text { operational structure, and managing } \\
\text { human resources. }\end{array}$ & $\begin{array}{l}\text { This is the first time a } \\
\text { state document has } \\
\text { directly focused on the } \\
\text { issues related to the } \\
\text { institutional autonomy } \\
\text { for higher education } \\
\text { institutions. It is } \\
\text { approved by Party } \\
\text { Committee of the } \\
\text { Ministry of Education } \\
\text { and Training as a } \\
\text { leading organ of the } \\
\text { Ministry. }\end{array}$ \\
\hline 12 & $\begin{array}{l}\text { Prime Minister's } \\
\text { Directive No. } \\
296 \text { on } \\
\text { Renovation in } \\
\text { Higher Education } \\
\text { Management }\end{array}$ & $\begin{array}{l}\text { February, } \\
2010\end{array}$ & $\begin{array}{l}\text { Identify a variety of higher } \\
\text { education challenges including low } \\
\text { level of educational quality, the } \\
\text { misalignment between higher } \\
\text { education reform and coherent } \\
\text { societal development, and the lack } \\
\text { of incentive systems for both } \\
\text { learning and teaching. }\end{array}$ & $\begin{array}{l}\text { This is the first time a } \\
\text { document issued by the } \\
\text { PM has attributed the } \\
\text { backward management } \\
\text { mechanisms and } \\
\text { policies as the key } \\
\text { reasons for the low } \\
\text { quality and limitations } \\
\text { of the national higher } \\
\text { education system. One } \\
\text { of the guidelines in this } \\
\text { directive is to clarify } \\
\text { the relationship } \\
\text { between state and } \\
\text { higher education } \\
\text { institutions in order to } \\
\text { increase the autonomy } \\
\text { for institutions while } \\
\text { assuring their } \\
\text { accountability to the } \\
\text { society. }\end{array}$ \\
\hline 13 & $\begin{array}{l}\text { Ministry of } \\
\text { Education and }\end{array}$ & $\begin{array}{l}\text { October 19, } \\
2010\end{array}$ & $\begin{array}{l}\text { MOET urged institutions to } \\
\text { continue reform in higher education }\end{array}$ & $\begin{array}{l}\text { While the Guideline } \\
\text { mentions the }\end{array}$ \\
\hline
\end{tabular}




\begin{tabular}{|c|c|c|c|c|}
\hline & $\begin{array}{l}\text { Training's } \\
\text { Guideline No. } \\
4713 \text {, on the } \\
\text { Focused Mission } \\
\text { of Higher } \\
\text { Education in the } \\
\text { 2010-2011 } \\
\text { School Year }\end{array}$ & & $\begin{array}{l}\text { management including the } \\
\text { implementation of decentralization } \\
\text { for institutions that meet the } \\
\text { qualification. The Guideline also } \\
\text { emphasized the need to publicize } \\
\text { institutions' commitments to } \\
\text { education quality and to develop } \\
\text { evaluation criteria and methods for } \\
\text { quality assurance as the criteria for } \\
\text { higher institutional autonomy } \\
\text { offered by the state. }\end{array}$ & $\begin{array}{l}\text { importance of } \\
\text { implementing } \\
\text { decentralization, it } \\
\text { emphasizes the } \\
\text { evaluation criteria, } \\
\text { quality assurance and } \\
\text { standardization as the } \\
\text { conditions for } \\
\text { decentralization. This } \\
\text { policy argument has } \\
\text { been embedded in most } \\
\text { of the recent higher } \\
\text { education policies } \\
\text { dealing with the issues } \\
\text { of institutional } \\
\text { autonomy. }\end{array}$ \\
\hline No & $\begin{array}{l}\text { Name of the } \\
\text { documents }\end{array}$ & Date & $\begin{array}{l}\text { Contents related to institutional } \\
\text { autonomy in the documents }\end{array}$ & $\begin{array}{c}\text { Policy implication for } \\
\text { institutional } \\
\text { autonomy }\end{array}$ \\
\hline 14 & $\begin{array}{l}\text { Higher Education } \\
\text { Law }\end{array}$ & June 2012 & $\begin{array}{l}\text { This new law was expected to } \\
\text { resolve the problems and } \\
\text { weaknesses of the higher education } \\
\text { system that surfaced during the past } \\
\text { two decades of economic reform. In } \\
\text { particular, it was expected to clarify } \\
\text { the relationships between the } \\
\text { government and higher education } \\
\text { institutions, especially in loosening } \\
\text { central government ties on the } \\
\text { administration of the institutions. } \\
\text { This law, however, lacks a specific } \\
\text { framework for implementing the } \\
\text { institutional autonomy of higher } \\
\text { education institutions (See the } \\
\text { Appendix for details). The law is to } \\
\text { be specified by } 36 \text { guiding } \\
\text { documents from the Ministry of } \\
\text { Education and Training, five } \\
\text { decrees of the Government, one } \\
\text { decision of the Prime Minister and } \\
\text { four inter-ministerial circulars. } \\
\text { This is the most important legal } \\
\text { document that reflects the policy } \\
\text { images and political priority of the } \\
\text { regime regarding the relationship } \\
\text { between the state and educational } \\
\text { institutions. In the case analysis } \\
\text { section, it will be examined in } \\
\text { detail. }\end{array}$ & $\begin{array}{l}\text { It took more than } 6 \\
\text { years for the proposal } \\
\text { to be submitted to the } \\
\text { National Assembly for } \\
\text { the first time in } \\
\text { November } 2011 \text { since } \\
\text { the Prime Minister } \\
\text { Resolution No. } 14 \text { on } \\
\text { Comprehensive Higher } \\
\text { Education Renovation } \\
\text { in } 2005 \text {. Yet, the } \\
\text { proposal was not } \\
\text { ratified by the National } \\
\text { Assembly because a } \\
\text { number of } \\
\text { parliamentary } \\
\text { members, along with } \\
\text { the public, criticized } \\
\text { the law for its lack of } \\
\text { specificity and } \\
\text { innovation in altering } \\
\text { the relationships } \\
\text { between the } \\
\text { government and higher } \\
\text { education institutions. } \\
\text { The Proposal was } \\
\text { submitted again to the } \\
\text { National Assembly } \\
\text { Session in June, } 2012 \\
\text { with some revision and } \\
\text { restructuring and was } \\
\text { ratified on June } 18 \text {, } \\
2012\end{array}$ \\
\hline
\end{tabular}


Table 9: Major policies and practices that limits autonomy of higher education institutions in Vietnam

\begin{tabular}{|c|c|c|c|c|}
\hline No & Name of policy & Date & Main contents & Policy implication \\
\hline 1 & $\begin{array}{l}\text { Decision No. } \\
\text { 76/2007/QĐ- } \\
\text { BGDĐT of } \\
\text { MOET }\end{array}$ & $\begin{array}{l}\text { December 20, } \\
2007\end{array}$ & $\begin{array}{l}\text { Focus on the accrediting } \\
\text { procedures and processes } \\
\text { for quality assurance of } \\
\text { vocational schools, junior } \\
\text { colleges and universities. }\end{array}$ & $\begin{array}{l}\text { Regulate and guide the } \\
\text { process by which institutions } \\
\text { are accredited and evaluated } \\
\text { based on the standards set by } \\
\text { MOET }\end{array}$ \\
\hline 2 & $\begin{array}{l}\text { Decision No. } \\
\text { 05/2008/QĐ- } \\
\text { BGDĐT of } \\
\text { MOET }\end{array}$ & $\begin{array}{l}\text { February } 5, \\
2008\end{array}$ & $\begin{array}{l}\text { Provide guiding procedures } \\
\text { for student selection and } \\
\text { admission for colleges and } \\
\text { universities. }\end{array}$ & $\begin{array}{l}\text { Regulate and provide } \\
\text { guidelines for the national } \\
\text { entrance examinations and } \\
\text { the procedures that } \\
\text { institutions need to follow to } \\
\text { enroll and admit students. }\end{array}$ \\
\hline 3 & $\begin{array}{l}\text { Prime } \\
\text { Minister's } \\
\text { Decision No. } \\
\text { 174/2008/QĐ- } \\
\text { TTg }\end{array}$ & $\begin{array}{l}\text { December 31, } \\
2008\end{array}$ & $\begin{array}{l}\text { Regulate standard, } \\
\text { promotion and removal } \\
\text { procedures in relation to } \\
\text { professor and asscociate } \\
\text { professors. }\end{array}$ & $\begin{array}{l}\text { The government still retains } \\
\text { the right to recognize and } \\
\text { promote professors and } \\
\text { associate professors at every } \\
\text { institution. }\end{array}$ \\
\hline No & Name of policy & Date & Main contents & Policy implication \\
\hline 4 & $\begin{array}{l}\text { Decision No. } \\
\text { 58/2010/QĐ- } \\
\text { TTg of Prime } \\
\text { Minister }\end{array}$ & $\begin{array}{l}\text { September } \\
22,2010\end{array}$ & $\begin{array}{l}\text { Promulgate the higher } \\
\text { education institutional } \\
\text { charter, including: (1) } \\
\text { missions and rights of the } \\
\text { institutions; (2) organization } \\
\text { of educational activities; (3) } \\
\text { scientific research and } \\
\text { technology development; } \\
\text { (4) international } \\
\text { cooperation; responsibility } \\
\text { and rights of teachers, } \\
\text { public employees and } \\
\text { officials; (5) responsibilities } \\
\text { and rights of learners; (6) } \\
\text { institutional organization } \\
\text { and management; (7) } \\
\text { financing and assets of } \\
\text { institution; and (8) the } \\
\text { relationship between } \\
\text { university, family and } \\
\text { society. This Charter applies } \\
\text { to all four-year public, } \\
\text { private and foreign-owned } \\
\text { institutions. }\end{array}$ & $\begin{array}{l}\text { This document provides a } \\
\text { guiding framework and set } \\
\text { of principles for universities } \\
\text { related to organizational } \\
\text { structure and operational } \\
\text { activities in different } \\
\text { administrative areas within } \\
\text { the higher education } \\
\text { institution. }\end{array}$ \\
\hline 5 & $\begin{array}{l}\text { Circular No } \\
\text { 10/2011/TT- } \\
\text { BGDĐT of } \\
\text { MOET }\end{array}$ & $\begin{array}{l}\text { February 28, } \\
2011\end{array}$ & $\begin{array}{l}\text { An example when MOET } \\
\text { provides the guidelines for } \\
\text { the training process of } \\
\text { master programs referring to } \\
\text { (1) educational institution; } \\
\text { (2) curriculum; (3) program } \\
\text { management; (4) inspection, } \\
\text { supervision, complain } \\
\text { resolving. }\end{array}$ & $\begin{array}{l}\text { This is an example of how } \\
\text { the MOET regulates the } \\
\text { training process at different } \\
\text { levels from undergraduate } \\
\text { programs to master and } \\
\text { doctoral programs. }\end{array}$ \\
\hline
\end{tabular}




\begin{tabular}{|c|c|c|c|c|}
\hline 6 & $\begin{array}{l}\text { Circular No. } \\
\text { 23/2011/TT- } \\
\text { BGDDT of } \\
\text { MOET }\end{array}$ & June 06, 2011 & $\begin{array}{l}\text { As an example when MOET } \\
\text { imposes the evaluation } \\
\text { standards for education } \\
\text { program in industrial } \\
\text { technique teacher training } \\
\text { undergraduate program (Su } \\
\text { phạm kỹ thuật công nghiệp) }\end{array}$ & $\begin{array}{l}\text { MOET promulgates the } \\
\text { standards by which the } \\
\text { education programs at all } \\
\text { institutions will be designed } \\
\text { and taught. The standards } \\
\text { include the objectives of the } \\
\text { program, the competencies } \\
\text { of graduates, the content } \\
\text { structure of the curriculum }\end{array}$ \\
\hline No & Name of policy & Date & Main contents & Policy implication \\
\hline 7 & $\begin{array}{l}\text { Circular No. } \\
\text { 57/2011/TT- } \\
\text { BGDĐT of } \\
\text { MOET }\end{array}$ & $\begin{array}{l}\text { December 02, } \\
2011\end{array}$ & $\begin{array}{l}\text { Instruct institutions to } \\
\text { identifying the student } \\
\text { enrollment quota at } \\
\text { undergraduate, master and } \\
\text { doctoral levels based on the } \\
\text { criteria of MOET. }\end{array}$ & $\begin{array}{l}\text { Indicate an incremental } \\
\text { change in admission policy } \\
\text { when the government allows } \\
\text { institutions to proactively } \\
\text { calculate their enrollment } \\
\text { number based on the } \\
\text { standards and guidelines of } \\
\text { MOET. Yet, they still need to } \\
\text { inform MOET of their } \\
\text { annual enrollment number. }\end{array}$ \\
\hline 8 & $\begin{array}{l}\text { Curriculum } \\
\text { Frameworks } \\
\text { for all } \\
\text { education } \\
\text { programs are } \\
\text { promulgated } \\
\text { by MOET }\end{array}$ & $\begin{array}{l}\text { January 13, } \\
2012\end{array}$ & $\begin{array}{l}\text { For example, the Program in } \\
\text { Defense and Security } \\
\text { Education is regulated by } \\
\text { the Circular No. } 02 \\
\text { /2012/TT-BGDĐT. }\end{array}$ & $\begin{array}{l}\text { MOET provides the } \\
\text { curriculum frameworks for } \\
\text { all academic programs } \\
\text { taught at the colleges and } \\
\text { universities. The curriculum } \\
\text { imposes (1) learning goals } \\
\text { and objectives (morality and } \\
\text { ethics, professional } \\
\text { knowledge, and skills); (2) } \\
\text { structure of the program } \\
\text { (number of credits and } \\
\text { specification of required } \\
\text { knowledge; and the structure } \\
\text { of knowledge). }\end{array}$ \\
\hline 9 & $\begin{array}{l}\text { Circular No. } 04 \\
\text { /2012/TT- } \\
\text { BGDĐT of } \\
\text { MOET }\end{array}$ & $\begin{array}{l}\text { February 15, } \\
2012\end{array}$ & $\begin{array}{l}\text { Provide the list of } \\
\text { educational and training } \\
\text { programs at the master and } \\
\text { doctoral levels that are } \\
\text { allowed to be taught at } \\
\text { colleges and universities } \\
\text { (Level IV List). }\end{array}$ & $\begin{array}{l}\text { All institutions, except the } \\
\text { two National Universities in } \\
\text { Hanoi and Ho Chi Minh } \\
\text { City, can only open } \\
\text { programs that are listed in } \\
\text { this document issued by } \\
\text { MOET. The two National } \\
\text { Universities can open new } \\
\text { programs as pilot projects } \\
\text { and subject to evaluation and } \\
\text { approval from MOET before } \\
\text { the new program is officially } \\
\text { taught at the university. }\end{array}$ \\
\hline 10 & $\begin{array}{l}\text { Higher } \\
\text { Education Law }\end{array}$ & June 2012 & $\begin{array}{l}\text { Regulate all issues of state } \\
\text { management in higher } \\
\text { education. It incorporates } \\
\text { and restructures most of the } \\
\text { recent legal documents in } \\
\text { higher education. (The } \\
\text { following section will } \\
\text { examine in detail the } \\
\text { contents of this Law). }\end{array}$ & $\begin{array}{l}\text { The law was expected to } \\
\text { provide a systematic } \\
\text { regulatory framework for the } \\
\text { development of higher } \\
\text { education system. It is, } \\
\text { however, still abstract and } \\
\text { lacks innovative policy } \\
\text { change that give substantive } \\
\text { autonomy for higher } \\
\text { education institutions. }\end{array}$ \\
\hline
\end{tabular}




\section{Case analysis: how policy factors determine policy outcomes?}

In the previous section, I have identified the policies and practices in Vietnam, those that support decentralization as well as the policies and practice that consolidate the control of government and MOET over higher education institutions. As have been mentioned previously, these policies and practices demonstrate a policy paradox: while agreeing to the need for greater autonomy for institutions, the government seems cautious about the possibility of losing control over the higher education system if autonomy is given to institutions without commensurate accountability and binding rules (Bui, 2011). Indeed, the newly-ratified Higher Education Law of 2012, which is the most up-to-date and important legal document related to institutional autonomy, reveals the reluctance of the government to delegate substantial autonomy to institutions in most of the important administrative areas, such as curriculum design, opening new programs, professor and president appointments, quality assurance and accreditation. The law indicates that the Socialist legacies have triumphed over the demand for decentralization and institutional autonomy. Amid criticisms and pressure to loosen the constraints on higher education institutions, the government tends to compromise with incremental policy changes instead of radical reform.

In this section, I will apply the major policy change model that I developed in Chapter III to guide my explanation on the policy process and outcomes in higher education sector of Vietnam. To do so, I will examine the role of the causal policy factors including stressors, leadership predisposition to reform and policy image of policy Party and government that are integral parts of the proposed policy change 
model. In the following sections, I will explore each of these questions in greater detail:

- Have the Vietnamese Party and government been aware of the stressors that were prompting higher education reform?

- Has there been predisposition on the part of Party and government to reform high education policy?

- Have the policy images of the policy elites in the Party and Government changed over the past years, especially in terms of the technical feasibility and political acceptability of giving more autonomy to higher education institutions?

\section{The stressors to higher education policy}

As have been explained in the proposed major policy change model in Chapter III, stressors are considered as independent variables in the relationship with the policy outcomes. Stressors to a policy subsystem may include: natural and human disasters, economic crises, structural changes in socio-economic conditions, critical changes in other policy areas, national mood, or international pressures. Adverse consequences may occur if the stressor is not addressed. Stressors served as the catalysts that make major policy change more likely to happen by disclosing new knowledge, new risks and new challenges. Thus, by underscoring anomalies in the prevailing policy paradigm, or raising the visibility of new problems, stressors can provide opportunities for policy learning within the policy subsystem which in turn change policy makers' perceptions of the problems, how they rank values or priorities, and how decisive they push for major policy change. 
In Section 2 of this Chapter, I have reviewed the both quantity and quality issues in the higher education that demonstrated the challenges and difficulties faced by the higher education system of Vietnam. In this sub-section, I will take a further step to identify if the Vietnamese Party and government has been aware of the external stressors and perceived the demand for higher education reform. By a reading of the contents, statements and languages of relevant resolutions, decrees, decisions, and directives, I hope to reveal the perceptions of the Party and government of Vietnam about the pressure for change.

At the Party level

In 1996, the $2^{\text {nd }}$ Plenum of the VIII Party National Congress of Vietnam produced a special Resolution No. 2 on Development Strategy for Education and Training in the Period of Industrialization and Modernization till 2000. This document marks an important point of time when the Party and government took the issue of education quality and development as the critical factor for the success of economic reforms. The resolution admitted the weaknesses and challenges of the education system, especially higher education. It pointed out that “our nation's education system has a great deal of limitations in scope, structure, especially in quality and efficiency; is unable to meet the increasing demand for human resources supporting the cause of economic reform, national construction and defense, and Socialist-oriented industrialization and modernization" (Communist Party of Vietnam, 1996). It is the first time that an important document of the Party apparently recognized that weaknesses in the educational system needed to be corrected if significant improvements were to be made in the economic system. The resolution concluded with the simple observation that state management of education including 
higher education is "inappropriate and is not able to encourage the activeness and responsibility of the local governments and schools" (Communist Party of Vietnam, 1996) .

This 1996 recognition of the external stressors to the education subsystem including higher education that were causing pressure for educational reform was intensified in 2002 by Conclusion No. 14 of the Party Central Committee on Education and Scientific Development. This conclusion pointed out that "besides achievements, the education system is facing a variety of difficulties and weaknesses, especially in terms of education quality and state management. The educational system has observed a disproportionate structure between tertiary education and vocational training and the demand for high quality human resource needed for economic development has not been met (Communist Party of Vietnam, 2002). This resolution indicated concern by the regime about the weaknesses and limitations of the education system in general and the higher education system in particular after Vietnam accepted further international economic integration by the Bilateral Trade Agreement with the U.S in 2001. In 2005, on the threshold of WTO accession, Vietnam adopted a revised Education Law along with a number of legal changes in response to the pressures arising from deeper international economic integration.

In April, 2009, the Politburo of the CPV issued a special Conclusion of the Politburo No. 242-TB/TW on the Direction for Education Development till 2020. Again, this conclusion strongly emphasized the fact that the national education system lags far behind the need of national development. Notably, the 2009 document is the first official example where the Party that has attributed the "backwardness and inappropriateness of state management in education as the key reason for all of the 
weaknesses and problems of the system" (Communist Party of Vietnam, 2009). The Party had to admit that education management reform has been very slow and far behind the reforms in other socio-economic sectors.

\section{At the government level}

In 2005, two of the very important government documents in higher education were issued by the Prime Minister and the Ministry of Education and Training: (1) the Prime Minister's Resolution No. 14/2005/NQ-CP dated 2 November on "Fundamental and Comprehensive Renovation of Vietnam Higher Education in the period of 2006-2020" and the Higher Education Reform Agenda (HERA) issued by the Ministry of Education and Training. These are the two most innovative guiding documents focusing directly on renovation in higher education. Resolution No. 14 asserted that "the achievements in the higher education development process is not sustainable, systematic, and substantial [enough]...for the cause of industrialization, modernization, the learning needs of the people and international integration of the country". The resolution reiterated the weaknesses and limitations in state management, education system structure, institution network, teaching method, teacher and education administrator quality, and the use of resource. These two documents were expected to set the stage for radical changes in state management in higher education, yet they did not provide concrete and deterministic decisions giving significant autonomy to institutions.

In February, 2010, the Prime Minister's Directive No. 296 on Renovation in Higher Education Management clearly identified a variety of higher education challenges including low level of educational quality, the misalignment between higher education reform and societal development, and the lack of incentive systems 
for both learning and teaching (Prime Minister of Vietnam, 2010). The Prime Minister called for a significant shift in focus from quantity to an emphasis on the quality of higher education. Once again, this directive attributed the backward state management mechanisms and policies as the key reasons for low quality and limited availability of higher education, which in turn detract the economic environment for investors and can slow the economic growth of the country.

At the National Assembly level

Following the Conclusion No. 242-TB/TW of the Politburo, the National Assembly promulgated a special Resolution No. 50 on the Implementation of Policy and Law in the Establishment of New Institutions, Investment and Quality Assurance in Higher Education, dated on June 19, 2010. The resolution identified problems in various aspects of higher education that contribute to low education quality. The problems include the establishment of new institutions without quality assurance, slow policy reform, limited institutional rights for universities and colleges, low quality teaching, lack of the linkage between research and training, and a weak accrediting system. This resolution revealed the disappointment of the National Assembly with the speed of reform and the further decline of the quality of higher education after two decades of reforming efforts.

\section{At the Ministry of Education and Training level}

As a national public organization in charge of state management of education including higher education, in a assessment report in 2009, the Ministry of Education and Training pointed out that “while Vietnam's higher education system is developing rapidly and on a large scale, state management is failing to keep pace and higher education management [is] lagging behind" (MOET, 2009). On January 6, 2010, the 
Party Committee of the Ministry of Education and Training issued the Resolution No. 05-NQ/BCSD on Innovation in Higher Education Management in the Period 2010-

2012. The resolution concluded that "the management of the Ministry of Education and Training in higher education has not been renovated enough in accordance to the universal governance rules in higher education and for the demands of social development" (Ministry of Education and Training, Vietnam, 2010). Accordingly, the state management is weak and inefficient because it violates the universal governance rules in the following areas: (1) teaching process: curriculum and pedagogical methodology; (2) state management and institutional administration; (3) individual incentive system; (4) financial management; and (5) technological application. This is the first time, an official document referred to universal rules for higher education management, yet it did not specify such rules. Also, in the same year, the Ministry of Education and Training issued Guideline No. 4713 on the Focused Mission of Higher Education in the 2010-2011 School Year in October. Through this guideline, MOET urged institutions to continue their reform initiatives in higher education management, including the implementation of decentralization for institutions that meet the qualifications.

In summary, from the evidence in the preceding sections, it is clear that all authority levels of the regime have recognized the existence of external economic stressors that trigger the need to reform the education system especially the higher education in response to a dynamic market economy and deeper international integration in all areas. More specifically, the regime increasingly perceived that state management and government policies in education are the main reason for the weaknesses and problems of the higher education system. Most recently, renovation 
of state management in education was considered as one of the three most urgent issues of the $6^{\text {th }}$ Plenum of the XI Party Congress just finished on October 15, 2012. Nonetheless, despite the recognition by the leadership cadre in both Party and government of the increasing stressors for innovative policy change in higher education, this reform has not materialized. In the next section, I will explore the next policy factor of the proposed policy model, the "leadership predisposition to reform", to see if the leaders in Vietnam really want to act upon the stressors they have officially recognized.

\section{Leadership predisposition to reform state management in higher education}

In the policy model proposed in this dissertation, the concept of "leadership predisposition to reform" was defined as a psychological readiness of the policy elites to advance innovative policy change initiative. This readiness is achieved only after the policy elites take into account the existing stressors along with the ideological commitments and political risks. Thus, leadership predisposition demonstrated the general commitments and willingness to policy change, which influence policy leaders' perceptions of what problems are and how they should be responded to. It can shape how the ruling elites perceive and articulate particular policy issues, how they assess the proposed change, and how they weigh political and technical factors in dealing with the existing policy problems. Once the predisposition to reform is reached within the leadership of the CPV by the issuance of relevant resolutions or decisions, the policy problems and policy change initiative will be officially advanced into the agenda of the National Assembly or government for further deliberation and studies. This, in turn, guarantees a chance for a policy reform initiative to be advanced into the next stage of the policy formulation and may be adopted in the future. In this 
section, I will document the leadership predisposition by the Party, National Assembly, Prime Minister and MOET to grant more autonomy to higher education institutions in Vietnam. Leadership predisposition can be demonstrated through the statements of different authorities in their resolutions, directives, decrees, or decisions.

Indeed, at the Party level, the first time the Central Party Committee referred to the concept of autonomy for schools including higher education institutions is in Resolution No. 2 of the Party's VII Congress in 1996 on Development Strategy for Education and Training in the Period of Industrialization and Modernization till 2000. Yet, the idea of delegating autonomy for institutions in this resolution was very illusive. Six years later, in the face of greater international economic integration, the Politburo promulgated Conclusion No. 14-KL/TW in 2002, which strongly emphasized the demand for innovation in state management in education. Specifically, for the first time, the Party pointed to the need to delegate administrative autonomy from the central government to education institutions, especially the universities, and the need to raise the responsibility of the local governments in education management, including the people's committees at the province, city and district levels.

In the same direction, two years after Vietnam joined the WTO, the Central Party of Committee of Vietnam in 2009 issued another Conclusion No. 242-TB/TW on the Direction for Education Development till 2020. Under the second solution for renovation in state management in education, the resolution calls for the need to "increase the autonomy and accountability of the schools while promoting transparency, publicity and supervision of the government agencies and social 
organizations in education management". These important documents of the Party clearly showed the intentions and awareness of the ruling Party to delegate greater autonomy to individual institutions. They were, however, abstract endorsements and did not provide concrete policy decisions to realize the autonomy of the institutions.

At the government level, in 2005, a very important legal document was promulgated by the Prime Minister called Resolution No. 14/2005/NQ-CP on Fundamental and Comprehensive Renovation of Vietnam Higher Education for the period of 2006-2020. This resolution urged fundamental and multi-faceted renovation in higher education in order to achieve substantial change in the quality, efficiency, and the operation of the higher education system. The resolution called for greater institutional autonomy, accountability and transparency. Teachers and school administrators were encouraged to proactively participate in institutional administration along with participation by the whole society. In the same year, a new Education Law was adopted. Notably, these significant documents of the government were to respond to the external pressures arising at the threshold of the accession to WTO.

The next important document showing strong predisposition to reform higher education was Directive No. 296 issued in February, 2010 by the Prime Minister. The directive called attention to the weaknesses and limitations in state management of higher education, which were cited as the major causes for the low quality and backwardness of the national higher education system. Among the solutions for changing the situation, the directive pointed to the need to clarify the relationships between state agencies and higher education institutions in order to increase the autonomy for institutions while assuring their accountability to the society. This 
directive was to realize Conclusion No. 242 of the Politburo issued in 2009. After these guiding document, the Ministry of Education and Training accelerated the policy making process to prepare the draft of the new Higher Education Law.

At the National Assembly level, a special Resolution No. 50 on the Implementation of Policy and Law in the Establishment of New Institutions, Investment and Quality Assurance in Higher Education was issued on June 19, 2010 in response to the slow speed of reforms and the low quality especially of the newlyestablished institutions. Among the solutions, the resolution emphasized the need for decentralization and greater autonomy in higher education and clarifying the responsibilities of the Ministry of Education and Training, other line ministries and provincial People's Committees in state management of the higher education system. It also calls for greater accountability, internal evaluation and self-control of institutions in implementing their missions, organizing institutional structure and process, and managing their human resources.

At the Ministry of Education and Training level, on January 6, 2010, the Party Committee of the Ministry produced Resolution No. 05-NQ/BCSD on Innovation in Higher Education Management in the Period 2010-2012. Similar to other guiding documents, this resolution emphasized the demand for decentralization, delegating powers in the way that would clarify the division of role among the Ministry of Education and Training, other line ministries and the local authorities; and encourage autonomy and accountability and internal control of institutions along with the increased supervision of state agencies and of the whole society. According to this resolution, public institutions are supposed to be autonomous in the areas of mission implementation, operative administration, faculty recruitment and compensation. 
Following the directives from the higher levels of authorities, the Ministry of Education and Training produced Guideline No. 4713 on the Focused Mission of Higher Education in the 2010-2011 School Year. The MOET's slogan for the school year 2010-2011 was “Continue to renovate management and promote education quality". In this document, MOET urged institutions to continue reforms in higher education management including the implementation of decentralization for institutions, which meet the qualification. The guideline also emphasized the need to publicize institutional commitments in education quality and to develop evaluation criteria and methods for quality assurance as to support decentralization. The ministry considers these requirements as the criteria for granting increased autonomy to individual institutions.

To summarize, by reviewing the key documents at all authority levels over the past two decades, we can conclude that there was predisposition by the Vietnamese Communist Party and government leaders to reform the state management in higher education including policy reform in administrative autonomy for tertiary institutions. The Party and government have continuously showed their commitments and intentions to decentralize and to delegate power as a solution to the existing problems and challenges of the higher education system. Yet, despite the recognition of the pressures for reform in order to address external stressors to higher education system and despite the predisposition of leaders to embrace reform, significant change has not occurred. How much of this resistance to change can be accounted for by the failure of the Party and government leaders to alter their policy image? In the next section we will explore the importance of this factor identified in my policy change model presented in Chapter III. 


\section{Policy image on state management in higher education}

In chapter III, I have isolated "change in policy image" of the policy elites as a potentially important factor in explaining major policy change in Vietnam. The concept of "policy image" was defined as the belief through which the policy actors interpret given policy issues; identify the causal relationships between these issues with the existing policies or the absence of a policy; and rationalize their solutions resolving the issues. Policy image also reflects the assumptions on the best way to realize the core values and political priorities of the Vietnamese regime in the transitional process of development. Significant change in the policy image is a precondition for the formulation of innovative/radical policy change alternative, which in turn enables the adoption of radical policy change in the next stage of the policy process.

In following section, I will document the evidence to answer the following questions: have the Party and its leaders seen decentralization as a solution to a particular set of policy problems? In another word, have the Party's and the government's policy image identified decentralization of higher education as the key solution to low quality performance in higher education? How have the Party and government perceived the roles of higher education institutions in the development of the country and the relationship between institutional autonomy and the legacies of a Socialist state in Vietnam?

Indeed, the early years of the 1990s witnessed a strong push for economic reform to attract a larger amount of foreign direct investment to Vietnam and to promote exports. During this period, the central-planning economic system was dismantled and replaced by a Socialist market-oriented system. With the initial and 
impressive achievements in economic development, the CPV and the government of Vietnam started to take into account the quality of the human resources in the market labor which were greatly influenced by the education system, especially the quality of higher education. To bring the quality of higher education into alignment with the growing economic vitality of the country, the Party and government have identified the factors that affect education quality and the solutions to improve the system in a variety of resolutions, directives and legal documents.

Beginning as far back as the first years of Đổi Mới, Resolution No. 4 of the $2^{\text {nd }}$ Plenum of the VII Party National Congress in 1993 identified education and training as "the motor to push and ensure the success of socio-economic goals". However, this resolution did not recognize backward state management and policy deficiencies as the sources of problems and weaknesses in the education system including higher education. In the solution section of the resolution, renovation in education management was listed as the last solution (the $12^{\text {th }}$ ), which mentioned the need to clarify the rights and responsibilities of the Ministry of Education and Training, line ministries, local government in education management. Only one sentence refers to the need for decentralization, "while the state's responsibility must be raised, education institutions need to be given rights, especially institutions of higher education, in order to promote democracy within these institutions" (Communist Party of Vietnam, 1993). The resolution indicated that at this point of time the Party did not consider state management including the policy on institutional autonomy as the key solution for quality improvement in education in general and in high education in particular. 
Three years later, Resolution No. 2 on Development Strategy for Education and Training in the Period of Industrialization and Modernization till 2000 issued at the $2^{\text {nd }}$ Plenum of the VIII Party National Congress in 1996 was produced as one of the key guiding documents of the Party for a long period time. The resolution recognized the challenges and difficulties in economic development if the education system, including higher education was not commensurately developed. The significant difference between this resolution and other previous documents of the Party and government related to the policy image. For the first time the Party identified inappropriate state management in education as the first reason for the weaknesses and problems of the education system. Among the problems in the state management system, the resolution identified the lack of strong autonomy and selfresponsibility of education institutions and local governments. However, in the solution section of this resolution, change and improvement in state management in education is ranked the $4^{\text {th }}$ as the last solution. Moreover, within this solution, the need to increase the autonomy for institutions, especially higher institutions, was listed as the last point. This suggests that even though the Party started to consider state management as the reason for the weaknesses and problems in the education system, state management in general and especially the policy on autonomy for higher education institutions had not yet been recognized as the most important target of policy and governance reforms.

The Conclusion No. 14-KL/TW of the Party Central Committee in 2002, at the $6^{\text {th }}$ Plenum of the IX National Party Congress, was the first important document of the Party that strongly emphasized the demand for innovation in state management in education as the solution for quality improvement. However, the first point in the 
solution section of the conclusion is to "increase the leadership of the Party and to improve leading capacity of the state" in higher education management instead of giving more autonomy for institutions (Communist Party of Vietnam, 2002). The conclusion repeated the need for delegation and decentralization in education management that promotes autonomy and pro-activeness of education institutions, especially of higher education institutions, along with the assurance of their accountability to the students, families and the whole society. The role of local people's committees and agencies in education management was also raised. Again, at this point, the Party had perceived the important role of innovation in education state management for quality improvement but did not see decentralization and delegation of administrative power as the first priority of reform.

The Prime Minister Resolution No 14/2005/NQ-CP on "Fundamental and Comprehensive Renovation of Vietnam Higher Education for 2006-2020" and the Higher Education Reform Agenda (HERA) issued by MOET in 2005 have been considered as the key documents which included the most innovative ideas and proposal in developing the higher education system in Vietnam over the past two decades. Produced at the threshold of the WTO accession, the resolution pointed to various solutions and policy reforms in order to improve higher education quality, meeting the demand for national economic development and international integration. However, in the resolution, changing the policy on autonomy and responsibility of higher education institutions is listed as the last goal of the reform. Especially, in the solution section, among six solutions, the solution that gives public institutions autonomy and self-administration in training, research, organization, personnel, and finance, was ranked $5^{\text {th }}$ after the solutions of reforming the institution network, 
curriculum innovation, personnel management, teacher training, and financial management. This indicates that until 2005, the Vietnamese government had not considered decentralization and greater autonomy as the first priority of reform, even though the right and autonomy of higher education institutions had been legalized in the Education Law of 1999 and the Amended Education Law of 2005.

Both of the laws had a separate article (article 55 in the 1999 law and article 60 in the 2005 law) to regulate the institutional autonomy of higher education institutions. Interestingly, after 7 years, the two articles in the two laws are exactly the same. They both generally identify five administrative rights of institutions in the following areas: (1) designing curriculum, textbook, teaching and learning plans for academic programs that are allowed to be taught by the Ministry of Education and Training; (2) identifying enrollment number, administrating the entrance examination, organizing education programs, offering degrees, and certifying successful graduates; (3) creating the organizational structure of the institution; hiring, managing and compensating teaching staffs; (4) Mobilizing and managing resources; (5) Partnering with international organizations. Yet, all of these rights are conditional because they are bound by other requirements and regulations of the government. For example, institutions can design their own curriculum for the education programs, but they must be based on the frame curriculum imposed by MOET; or institutions can open new programs but they must be in the government list of permitted programs and must get the approval from MOET; or institutions can identify the admission quota but the final quota for each university must be approved by MOET.

The Resolution No. 05-NQ/BCSD on Innovation in Higher Education Management in the Period 2010-2012 issued by the Party Committee of the Ministry 
of Education and Training on January 6, 2010 is the first document in a series of guiding documents issued by the Ministry of Education and the Prime Minister in relation to renovation of state management in higher education. The resolution emphasized the need for innovation in the "quality" of higher education state management including (1) building rules that regulating the role in state management of different entities, the organization and operation of university council, and the development of the accrediting system; (2) enhancing administrative reform in higher education management; (3) encouraging institutional autonomy and accountability, and internal assurance and self-control especially in implementing institutional missions, organizing operational structure, and managing human resources (Ministry of Education and Training, Vietnam, 2010). It is discernible in this resolution that the government and MOET did recognize the strong demand for innovation in the higher education management system, including the demand for more autonomy for institutions. However, increasing autonomy for institutions has still not been considered as the first priority in reforming state management in higher education. Autonomous rights for universities and colleges are frequently mentioned together with the need to consolidate state supervision and oversight. For example, the resolution asserted that "promoting internal autonomy, self-responsibility and selfmonitoring within the institutions based on the regulations of the state and institutions while increasing oversight and inspection of the state, society and the institutions themselves" (Section 2.3.3).

One month afterward, the Prime Minister's Directive No. 296 in February, 2010 vehemently called for reforms of the higher education state management system. It considered renovation in state management of higher education as an opportunity to 
create a significant and comprehensive improvement in quality. However, again, when identifying the concrete solutions for renovation in state management of higher education, giving more autonomy to higher education institutions and clarifying the management responsibilities between institutions and government agencies was ranked only $6^{\text {th }}$ among the 12 solutions. Still, the directive only gave general principles instead of specific guidelines for bestowing greater autonomy on higher education institutions. Moreover, it emphasized the need to increase the role of local governments in higher education management (to supplement the role of the central government) and the supervision of the state and society over the institutions.

In the Ministry of Education and Training's Guideline No. 4713 on the Focused Mission of Higher Education in the 2010-2011 School Year in October, 2010, MOET urged institutions to continue reform in higher education management including the implementation of decentralization for institutions that meet the qualifications. The only difference between this document and the previous documents in the same year is that it put decentralization of higher education management as the first task to implement management reform. However, similar to the previous documents promulgated by the Party and government, this document provided only a general understanding of the need to giving more autonomy for institutions but did not articulate a strong linkage between institutional autonomy and improvement in educational quality and state management. Also, it did not identify a concrete regulatory framework for decentralization and as usual, institutional autonomies were accompanied with conditions and criteria. For example, the government and MOET argued for quality standards and accreditation as the criteria to identify different levels of autonomy granted to individual institutions. Institutional 
autonomy for higher education is not considered as the inalienable rights of institutions as being considered in some Western countries.

In addition to the review of official documents produced by the Party, the government and MOET, the following section will review some interviews of policy elites in order to get more evidence on the policy image of the regime regarding institutional autonomy for higher education institutions.

\section{Additional evidence of the policy image of the policy elites in MOET}

In this part, I am going to review three interviews I retrieved from the website Báo Dân Trí (Intellectual Forum) which is one of the most popular public news agencies covering the topic of education in Vietnam. The interviews provide additional information about the policy image of the policy elites that will supplement the review of the legal documents summarized in previous sections of this chapter. I was particular interested in isolating the information that would shed light on whether there had been any shift in "policy image" regarding institutional autonomy for higher education institutions on the part of party and government leaders at the moment.

Two of the interviewees are particularly well situated to shed light on this inquiry. Both of them play a role of official spokespersons for the Ministry of Education and Training, which is the focal point agency in designing and proposing the Higher Education Law of 2012. Their views revealed in these interviews represent the most recent views of the policy elites and policy makers of the CPV and government with regard to the institutional autonomy of higher education institutions.

The first interviewee is Bùi Văn Ga, the Vice Minister of Education and Training. He used to be the President of Đà Nẵng University before he was appointed as vice minister in 2009. At MOET, Vice Minister Ga is in charge of management of 
higher education and serves as the primary official assisting the Minister in this policy domain. The first interview was recorded at the press conference on 26/10/2011 published by Báo Dân Trí (Bui G. V., Dan Tri, 2011). This interview was conducted right before the Higher Education Law was submitted to the National Assembly for review in November, 2011. Mr. Ga was charged with providing an introduction to the media press on the key points of the proposed law. His views represent for the policy images of the Party and government in higher education at that time.

To begin with, the Vice Minister asserted that "delegation of autonomy to institutions and quality assurance are the key objectives of the proposed law. Autonomy and accountability cover the following areas: organization and personnel, financial and asset management, training and research management, international relations, quality assurance and accreditation”. However, he continued, “Autonomy needs to be attached to accountability of institutions because right now institutions are not really accountable. For example, whenever there is a scandal or problems, the learners come to see the state agencies and require them to resolve their problems since the relationship between the learners and the institutions are not so good". Thus, he argued that autonomy needs to go along with accountability and whenever the accountability is high then autonomy will be higher accordingly.

The Vice Minister emphasized that due to the diversity of the higher education system with universities and colleges of different tiers and capacities, if the institutional autonomy is delegated to all institutions, there will be "chaos" within the higher education system. Therefore, there needs to be a "pathway that only institutions with adequate capacities are to be granted autonomy along with their accountability". The Ministry of Education and Training will grant autonomy to 
individual institutions based on the accreditation results. If a school lacks capacity or violate the rules, its autonomy will be withdrawn. This is intended to create competition among the institutions.

Two main principles are employed to decide the autonomy for institutions: (1) institution classification is used to identify the type and level of autonomy for each institution; (2) the accreditation system is the tool to identify the quality and capacities of institutions which in turn determine respective institutional autonomy for individual institutions. For example, regarding the student admission and enrolment quota, based on the capacities of institutions, some institutions will have the rights to decide the enrolment number and admission methods by themselves.

The second interview with Mr. Ga was recorded at the press conference announcing the New Higher Education Law of 2012, on June 17, 2012 (Bui G. V., Dan Tri, 2012). This is a press conference that was conducted right after the National Assembly ratified the law in June 2012. It should be noted that in November 2011, the proposed law was first submitted to the National Assembly. However, it was not approved in 2011 due to a great deal of criticism of the proposal. A number of national assembly members and scholars argued that the proposal lacked decisive ideas and solutions for innovation in state management and it needed careful revision.

At this conference, Vice Minister Bùi Văn Ga asserted: "The Ministry of Education and Training will not interfere deeply into the operation of institutions when the autonomy is expanded to every institution". This is the first time a senior official of MOET stated that "releasing the ties to the central government is important for the improvement of education quality". Notably, the Vice Minister pointed out that "autonomy is an inalienable characteristic (thuộc tính) of higher education 
institutions". However, he also asserted that "autonomy should be relevant to and in accordance with the capacities and conditions of institutions to ensure the quality of education and training”. These seemingly conflict views, again, demonstrated a compromise between the need for greater institutional autonomy and the requirement of control and oversight on the part of the Vietnamese government.

The Vice Minister continued to emphasize that autonomy must be attached to accountability and the highest social responsibility of institutions is to ensure educational quality. Quality should be linked to the brand name of institutions. In delegating autonomy to universities, the new law refers to the need for increased role of university councils. Also, accreditation is compulsory to every institution because based on the accreditation results; the state agencies decide the type and degree of autonomy delegated to individual institutions. Vice Minister Ga raised two new points in the new law. First, instead of dictating curriculum, the law allows the government to regulate the standards on minimum knowledge and skills for each of the education programs at universities and colleges. Second, the law permits institutions to raise tuition fees for high quality programs.

To conclude, the Vice Minister informed that the new Higher Education Law of 2012 would be specified and implemented by the issuance of 36 guiding documents from the Ministry of Education and Training, five decrees of the government, one decision of the Prime Minister and four inter-ministerial circulars. That means the law just provides general terms and principles for higher education management. In order to realize the autonomy of higher education institution and to implement the law, the government and its agencies need to issues a variety of decrees, directives and circulars to concretize the terms and regulations of the law. 
The policy implication is that it will take more time, even years, for the Party and government to consider and build a comprehensive framework providing specific reforms in statement management in higher education sector.

Another interviewee was Ngô Kim Khôi, the Deputy Director General of the Higher Education Department of MOET. Mr. Khôi was the Deputy Director of the Proposing Committee of the Higher Education Law. The interview was conducted on October 26, 2011, right before the proposed law was submitted and reviewed by the National Assembly in November 2011 (Ngo K. K., Dan Tri, 2011). The following are the most important points raised by Mr. Khôi.

- The Higher Education Law was based on the guiding principles of the Resolution of the XI Party National Congress, the Resolution No. 2 of the VIII Congress and other conclusions and resolutions of the Party Central Committee and the Politburo. Concretely, the law is to realize the views and strategies of the Party in higher education management, to increase the leadership of the Party, and to promote the participation of the people in quality improvement of higher education.

- The law enhances decentralization, autonomy and proactiveness of the higher education institutions in the following areas: organization and personnel, training and scientific research, international relations and quality assurance. However, autonomy must be linked to the accountability and the capacity of the institution and must be ensured by a transparent accrediting system.

- The new Higher Education Law will specify the general terms in the Education Law of 2005 in relation to higher education. 
- The new law will systemize and integrate the existing separate rules and regulations in various legal documents related to higher education management.

All of these points raised by Mr. Khôi did show the intention of the government and MOET to delegate the power to institutions. Yet, the autonomy must be conditional on accountability. Also, the key autonomous aspects are not specified and only mentioned in abstract manner.

To summarize, over the recent years, the Party and government have increasingly recognized the need for the educational system to be restructured to address economic stressors and the leadership has shown a predisposition to follow through with intentions of reform. At all levels of leadership, the regime has come to attribute the backwardness and limitations in state management in higher education as serious problems that needed reforming; and among the solutions to renovation of state management in higher education, increasing institutional autonomy for higher education institutions was identified. Yet, based on the evidence found in this section, we can conclude that there was no significant change in the policy image of the Party and government of Vietnam with regard to state management in higher education. The Party and government have not perceived and clearly articulated a strong positive correlation between increase autonomy and higher education quality. Although delegation and institutional autonomy have been mentioned as one of the solutions for better performance of state management (which in turn has been identified as the key for quality improvement in higher education), they are not considered by the government the first priority of policy change. In addition, the legacies of a socialist state prevent the regime from freeing the higher education institutions. The 
government's lack of trust and credibility on higher education institutions make the state cautious about the negative consequences if autonomy is not guaranteed by adequate accountability and quality assurance.

In this regard, there has been a policy paradox between a desire of the government to decentralize decision-making to higher education institutions for the purposes of achieving greater efficiency and effectiveness in the use of resources and a desire to retain control of the Socialist orientation over higher education. Senior policy makers in the Ministry of Education and Training have expressed in the interviews their intention to delegate a greater degree of autonomy to the colleges and universities to (1) reduce the workloads of national decision makers due to the rapid increases in the numbers of institutions; (2) facilitate educational management innovation; and (3) integrate well-accepted mainstream principles of good education management (Ho \& Berg, 2010). These desires tend to conflict with the Party's need to maintain the Soviet model of managing higher education with the following principles.

First, the higher education institutions are mandated to provide the human resources for specific economic development demands and to support a state-led industrialization process rather than operating on the rules of free labor market. Higher education system development should be led by the will of the state and state should be in the position to determine the direction of education development. There is a fear that without state control, families, students and schools will not be able to promote a well-organized higher education system meeting the demands of the socioeconomic development strategies directed by the state. Second, the Party is concerned about ensuring accessibility of higher education for the economically disadvantaged 
students. This argument is supported by the fact that the National Assembly rejected a proposal for increasing tuition in 2006 and that the government still set the frame of tuition rate for both public and private institutions. Ensuring social equality and the welfare system of its citizens allow the CPV and its government to maintain the leadership legitimacy as the single political force representing for the labor classes in Vietnam. Third, the Party wants to maintain control over the ideological content of education to ensure the indoctrination of the younger generations, especially those students educated in private and foreign programs. In practice, except for programs organized by foreign institutions and for foreign students, all higher education programs need to teach political courses that ensure the "socialization" of younger generations in accordance with Marxist-Leninist ideology and Ho Chi Minh Thought (Education Law, 2005).

Until now, in the face of the above policy paradox, the regime still embraces the legacies of a Socialist state rather than a decentralized system. That explains the lack of significant change in the policy image on the role of institutional autonomy in quality improvement, which in turn prohibited the Vietnamese government to adopt innovative policy change alternative to change the relationships between the state and higher education institutions. The Higher Education Law of 2012, which was expected to be an innovative and comprehensive legal framework, has demonstrated the triumph of the Socialist legacies over the demand for higher institutional autonomy and even the demand for higher quality of the human resources (see the Appendix for the details of the Higher Education Law). As the result, policy changes in this policy domain have been incremental and conditional over the past two decades even though the Party and government of Vietnam have repeated pointed to 
the need for policy change in state management in general and in giving more autonomy for higher education institutions in particular.

It should be noted that due to the lack of significant change in the policy image of the Party and government in relation to institutional autonomy for higher education institutions, I am not going to review the forth policy factor of the proposed policy model (consensus on Party political priority) because no innovative policy change alternative has been formulated, and proposed to the Party Central Committee for final adoption. The Higher Education Law of 2012 is no more than a gathering of previous regulations in higher education with some incremental changes.

\section{Process-tracking of the cases}

In order to consolidate my proposed major policy change model for Vietnam, it is necessary to examine whether other policy factors have been at play in the policy change process. Specifically, I will explore whether other factors such as policy entrepreneurs, advocacy coalitions or interest groups may have been more important than the policy factors proposed in my policy change model in Chapter III and discussed in detail in section two above. Indeed, from what I have observed and studied, there is evidence that an advocacy-coalition or interest group factors may have played some influences on the higher education autonomy debate in Vietnam. For example, the Association of Non-public Universities, which was established in 2004 has been a strong voice in favor of higher education autonomy. This association represents the non-public universities that have been established with significant investments from private enterprises and/or social organizations. Members of this association have lobbied for more institutional autonomy for their institutions. They want to have greater autonomy over the use of their investment dollars. 
This association is not in a position to strongly influence policy-making process in higher education of Vietnam. For example, there was a meeting organized by the association to comments on the proposed Higher Education Law in 2010. However, no representative from the Ministry of Education and Training attended the meeting to take into account the views and ideas raised at the meeting. In addition, according to the law of Vietnam, this association is a kind of social organization, which in fact is under the supervision the Ministry of Home Affairs. That means it is not officially authorized to have an independent voice and legitimate policy input to the policy making process in higher education, and is subject to government control and oversight. This kind of control prevents the organization from having the kind of influence and role that meets the test of interest group and advocacy coalition theories. In addition to this association, the newly established Association of Public University and College Presidents is supposed to participate in the process-making process in higher education. However, it is still in the initial stage of development and dependent on MOET for resources.

In addition to these associations, there are some scholars and members of the National Assembly who have advocated for increasing autonomy for higher education institutions such as Mr. Đào Trọng Thi, Mr. Nguyễn Minh Thuyết, and Mr. Nguyễn Ngọc Trân. They used to be senior professors and administrators at the universities before becoming National Assembly members. During their terms at the National Assembly, these members have argued for significant and substantive autonomy for higher education institutions. However, their views and ideas have not influenced the final policy outcome. In fact, the policy is deliberated within different authorized 
committees of the government and Party and must be a product of a collective and consensus-based decision making process.

\section{Conclusions on the relevance of the proposed policy change model to the} case

The proposed policy change model in Chapter III has demonstrated its explanatory capacity in analyzing the policy phenomena in the higher education sector of Vietnam. The policy factors including stressors, leadership proposition to reform and policy image help clarify the policy context of the policy process in higher education over the past two decades. In particular, the concept of policy image is helpful in explaining the absence of innovative/radical policy change in higher education sector in Vietnam. Indeed, due to the lack of policy image change in the state management in higher education, no innovative policy alternative related to the level and type of institutional autonomy in the Higher Education Law of 2012 was discussed and adopted. Thus, without examination of the Party's core values and political priorities, the lack of policy image is enough for me to explain the absence of radical policy change in this area. The following is a summary of the major findings in the case, which are relevant to the proposed policy model.

\section{The Party and government have recognized the stressors for reform in}

\section{higher education}

Over the past two decades, there have been increasing stressors on the Party and government of Vietnam that have pushed them to grant more institutional autonomy for higher education institutions in Vietnam. The leadership at both Party and government levels has been aware of the demand for changes in the way the state manages the higher education system. Quality and quantity indicators reviewed in 
Section 1 of this chapter have revealed the challenges to the higher education sector in Vietnam which in turn can undermine the success in the economic reforms initiated by the Party and government since Đổi Mới. By reviewing different legal documents in subsection 2.1, I have shown that the stressors have been embedded and expressed at all levels of authority within the regime. The stressors have come mainly from the demand for high-skilled work forces to meet the development of the economy and the deeper international economic integration of Vietnam especially when Vietnam joined the WTO.

Indeed, recent reports produced by McKinsey Global Institute, the Consultative Group Meeting of 2011, and the Economic Committee of the National Assembly have revealed low productivity level in Vietnam and declined contribution of productivity and labor skill in the overall economic growth (McKinsey Global Institute, 2012; The Vietnam Consultative Group Meeting, 2011; National Assembly of Vietnam, 2012). Two well-known reports on higher education system in Vietnam produced by the Harvard Kennedy School of Government in 2008 and 2010 even used the word "crisis" to describe the status of the system. From 2005 until the present, the CPV, the National Assembly, the Prime Minister and the Ministry of Education and Training have repeatedly admitted the problems and weaknesses of the higher education system and the need to change state management in this area for quality improvement. The newly ratified Higher Education Law of 2012 and the fact that renovation of education system was set as one of the three urgent issues at the important $6^{\text {th }}$ Plenum of the CPV just finished on October 15, 2012, demonstrated increasing pressure on the CPV and government to act in this area. 


\section{The Party and government have demonstrated a predisposition to reform}

In subsection 2.2, I have reviewed the key official documents of both Party and the government of Vietnam and have shown that the Party and the government demonstrated their leadership predisposition to reform state management of education in general and higher education in particular. The Party and the government have repeatedly expressed their intention to delegate more institutional autonomy to higher education institutions. The magnitude and visibility of the predisposition of leaders to reform has increased gradually along with the visibility of stressors from international economic integration that push for more and faster educational reform.

The Prime Minister's Resolution No. 14 on Comprehensive Renovation in Higher Education in 2005 indicated a strong intention by the government to make radical change in this area to improve quality in response to the prospective accession of Vietnam into the WTO. Four years later, in 2009, the CPV issued a special Resolution in Education, which reinforced the previous predisposition to policy reform in education in general and in higher education in particular. Following this Party's resolution, the Prime Minister's Directive No. 296 on Renovation in Higher Education Management, and the Resolution No. 05-NQ/BCSD on Innovation in Higher Education Management in the Period 2010-2012 in 2010 demonstrated government's intention to renovate state management of higher education. As the result of this strong leadership predisposition in this area, from 2010, the proposed law on higher education management was advanced to the legal agenda of the Ministry of Education and Training and then the agenda of the National Assembly. Two years later, after a delay in 2011, the Higher Education Law was ratified in June 2012. 
Notably, even though the Vietnamese Communist Party have issued a number of resolutions and conclusions to direct the development of education and changes in state management of education, these documents are general to all types of education, including higher education. In fact, there has been no specific Party's resolution directed at renovation of higher education despite the National Assembly's resolution in 2009 and Prime Minister's directive in 2010 targeted directly at state management of higher education. The lack of a resolution on state management of higher education produced by the Party Central Committee shows a vacuum of the Party leadership in this area.

The lack of significant change in policy image prohibited innovative change

\section{in higher education policy on institutional autonomy}

In subsections 2.3 , I have examined the policy image of the Party and government in relation to state management of higher education in general and of the issue of institutional autonomy for higher education institutions in particular. By reviewing official documents of the Party and government and three interviews with two policy elites in higher education, we conclude that the regime has changed the policy image in the role of state management in quality improvement by attributing the weaknesses of state management as the main reason for the low performance of higher education institutions. The concept of state management, however, has been defined in broad terms including all the issues such as teacher training and compensation, financial policy, curriculum innovation and training organization, state oversight, the relationship between state and institutions and so on. Within state management, increase in institutional autonomy has not been considered as the first priority and solution for better education quality. The regime has not clearly 
articulated the lack of institutional autonomy as major liabilities to low performance of the education system.

Even though, recently, Vice Minister Bùi Văn Ga stated that "institutional autonomy is an inalienable right of the tertiary institutions", this statement has not been institutionalized in specific legal framework (Bui G. V., Dan Tri, 2012). The idea that institutional autonomy is something naturally belonging to the higher education institutions rather than granted by the government has not been accepted within the Party and government of Vietnam. The much anticipated recent Higher Education Law of 2012 was expected to substantively deliver on the repeated rhetorical promises of reform. However, the legacy of a Socialist state that has inculcated the policy elites makes them consider higher education institutions as agencies that need to be mobilized for the cause of industrialization and modernization. The dominated policy image has been that universities are established and supported by the state and therefore, they need to focus their missions to serve the socio-economic development goals initiated and led by the state. As the result, the Vietnamese Party and government might refer to the need to give more autonomy for universities and colleges, however its leaders do not necessarily see the strong and direct link between greater institutional autonomy and the demand for better human resources.

To conclude, over the years of Đổi Mới, the Vietnamese Party and government have struggled to balance two development visions - a "market - led" versus a "Socialist-oriented" vision in higher education (Tran, 2009). In striking this balance, the Party and government have accepted a number of incremental policy changes that increase the institutional autonomy for institutions in some administrative and 
management areas. However, whenever, the regime has faced the issue of endorsing the principle of decentralized autonomy, the Socialist legacy of concern for political stability and state control has had greater priority. The dominance of the Socialist legacy over the demand for decentralization makes significant change in the policy image in this domain impossible. As the result, a specific regulatory framework providing substantive and significant institutional autonomy for higher education institutions in Vietnam has not been adopted despite considerable pressure and rhetoric to do so. 


\section{Chapter VI: How was radical policy change made under the Bilateral Trade Agreement between Vietnam and U.S?}

After eleven years of negotiations for admission, Vietnam eventually became the $150^{\text {th }}$ member of the World Trade Organization (WTO) in November 2006. This was a long process with a critical breakthrough that occurred in 2000-2001 with the negotiation and signing of the Vietnam-United States Bilateral Trade Agreement (VNUSBTA). Together, these radical changes in trade liberalization triggered increasing optimism in the prospects for growth and development of the country through the expansion of international trade, increase in foreign direct investment and further domestic governance reform (Vo \& Nguyen, 2009). On the surface, the process of liberalizing international trade and joining the WTO seemed to be an easy effort and an inevitable consequence of Vietnam's integration into the world economy, resulted from the Renovation Program - Đổi Mới since 1986.

However, when we take a deeper look at the policy process over a decade before Vietnam became a member of WTO, the liberalization of trade policy does not seem easy or inevitable. We will see that as Đổi Mới reforms have deepened, there has been a lack of consensus within the Communist Party of Vietnam (CPV) as to the speed, depth, and pace of further reforms (Dinh Q. X., 2000). To reach the final decision to sign the trade agreement with the U.S and then to join the WTO, the Vietnamese Party and government had to reach consensus and overcome contentious debates and divergences in the policy images and the political priorities deemed best for the regime. 
This chapter will examine the reform of trade liberalization to delve more deeply into Vietnam's policy process in order to better understand the factors that seem to be associated with major shifts in policy outcomes. The objective of this study is not to evaluate the concrete negotiation terms or the achievements of Vietnam through the Bilateral Trade Agreement (BTA) or to identify the effects of trade liberalization on economic performance. Instead, I will focus on the critical policy factors that were in play at given points in time during the period of debate over the liberalization of trade policy and how they affected the policy outcomes. In so doing, the case will shed light on the subtleties and nuances of Vietnam's policy making process that can help validate the explanatory capacity of the proposed major policy change model in Chapter III of this dissertation.

In undertaking this case study, I will focus particularly on the role the following factors playing in the debate over the liberalization of trade policy: the role of stressors, leadership predisposition to reform, change in policy image and consensus on political priorities of the Communist Party of Vietnam and government at given points of time. In examining the role these factors playing in the trade liberalization debates, I hope to uncover how the Vietnamese Party and government gradually changed the policy beliefs and reached a working consensus to initiate a major change in this policy area.

To be clear, I will only focus on the VNUSBTA signed and ratified in 20002001 as my main subject of analysis in this chapter. There are two reasons for limiting my focus. First, the objective of the case studies in this dissertation is to verify the applicability of the policy change model proposed in Chapter III. To accomplish this goal, I do not need to examine every case in a given policy domain but to focus on a 
critical case. Second, the VNUSBTA is considered the breakthrough event in the trade liberalization process that set the stage for Vietnam to enter the WTO. The radical policy change outcome of the VNUBTA is the relevant unit of analysis for the purpose of selecting a trade liberalization case study for this dissertation.

I will undertake an examination of the negotiation and adoption of the VNUSBTA in four steps. First, I will review the context of Đổi Mới in which Vietnam negotiated and made necessary commitments to trade liberalization and legal reforms. This part will include the timeline with critical points of policy change in liberalizing Vietnam's trade regime from 1986 to 2006 when Vietnam was finally admitted as a member of the WTO. In the second part, I will review the potential benefits and challenges that occur as Vietnam went through the process of liberalizing its international trade policy. This second part of the chapter serves as the foundation for the analysis of the policy factors in the following sections. The third part of this chapter will examine how the policy factors (stressors, leadership predisposition to reform, significant change in the policy image, and the Party's consensus on political priorities) came into play to determine the policy outcomes at different points of time before Vietnam finally accepted the VNUSBTA in July, 2000. Finally, some conclusions will be drawn about the relevance and explanatory capacities of the policy change model proposed in Chapter III in analyzing the radical policy change in this case study.

\section{Introduction to the case: Đổi Mới and the requirements for trade}

\section{liberalization}

Vietnam's renovation process since 1986 was influenced by both internal circumstance and the external environment. Internally, by the second half of the 
1980s, Vietnam was suffering a serious economic crisis. According to World Bank statistics, the annual food output per capita fell from $304 \mathrm{~kg}$ in 1985 to $281 \mathrm{~kg}$ in 1987; the inflation rate was $90 \%$ in 1985 , and $455 \%$ in 1986; and GDP per capita fell from \$101 in 1976 to \$91 in 1980 (World Bank Report cited in Vu, 2010). Externally, the collapse of the Soviet Union Block in Eastern Europe had caused the decline of assistance from and trade with the former Socialist ally countries. The crisis forced the CPV to end decades of isolation and embark on a series of economic and social reforms (Dinh, 2000).

The Renovation Program - Đổi Mới was marked by the shift from centralplanning economy to a market-oriented economic system characterized by: (1) the expansion of the private sector in both domestic and international business; (2) the promotion of international trade with an export-driven integration with the world economy; (3) a variety of governance reforms in the areas of agriculture production, banking, international exchange rates, taxes, land ownership and state-owned enterprises. The key objective of all these reforms was to rely more on market forces in the allocation of resources and in the determination of prices with a corresponding reduction in Party and government command structures for allocating resources $(\mathrm{Chu}$ \& Dickie, 2006). The reforms yielded unprecedented levels of growth. Vietnam's economy doubled in size during a decade after Đổi Mới, while its poverty rate halved; in average, exports grew by 20 percent per year (substantially faster than GDP), and foreign direct investment (FDI) increased by 10 percent per year reaching the peak in 1996 (Dinh, 2000). 


\section{Critical turning points in Vietnam's accession to the WTO}

Among the reform areas under Đổi Mới, international economic integration in general and trade liberalization in particular was a strong focus. Vietnam first applied for membership in the GATT/World Trade Organization (WTO) in 1994 and became an observer country of this organization in 1995 . However, the first important cornerstone of the international economic liberalization towards a market economy was the Foreign Direct Investment Law promulgated in December 1987 (Nguyen \& Haughton, 2002). This law was considered a rather liberal and progressive legal framework at the time, demonstrating the desire of the Vietnamese government to attract foreign capital and promote international market access for Vietnam's exportled economic strategy (Chu \& Dickie, 2006). The law welcomed FDI in all economic sectors, permitted 100 percent foreign ownership in a number of areas, provided generous tax and duty exemptions in many preferable areas, and guaranteed repatriation of capital by foreign investors. The FDI initiative was followed in 1990 by the promulgation of the Private Enterprise Law and the Law on Companies. These two laws allowed private enterprises that satisfied a number of conditions to obtain an import license from government authorities to engage in import-export activities (Pham, 2011). The third important law in the progression toward the liberalization of Vietnam's trade policy was the passage of the first Import and Export Duties Law of Vietnam in 1991, which was then amended in 1992 and 1998 to integrate and systematize the tariff practices of the country.

In parallel with these domestic legal reforms, Vietnam has undergone a process of negotiation with regional and global economic entities by joining the Association of South East Asian Nations (ASEAN) in 1995 and becoming a member 
of the ASEAN Free Trade Area (AFTA). In the same year, Vietnam started its negotiation process to be a member of the WTO. Vietnam then became a member of the Asia-Pacific Economic Cooperation (APEC) in 1998.

Beginning in 1996 as an integrative part of WTO accession, Vietnam started to negotiate the Vietnam-United States Bilateral Trade Agreement (VNUSBTA), which was a milestone in Vietnam's trade liberalization process. This is because it contains many fundamental principles required of members of the WTO, including Most Favored Nation (MFN) status, transparency, discipline related to trade in goods, Trade-Related Investment Measures (TRIMS), Trade-Related Aspects of Intellectual Property Rights (TRIPS), General Agreement on Trade in Services (GATS) and the WTO’s Basic Telecom Reference Paper (Pham, 2011). The Asian Financial Crisis in 1997 pushed Vietnam to accelerate economic reforms including trade liberalization. However, as a key bilateral trade agreement for Vietnam, the Vietnam-US BTA is one of the most controversial documents and witnessed contentious and divided deliberations within the highest authorities of the regime over a period of five year from 1996 to 2001.

Despite difficulties and controversies, the VNUSBTA was finally signed in July 2000 the two governments and then ratified by the U.S Congresses and the National Assembly of Vietnam to become law on $10^{\text {th }}$ December, 2001. The BTA with the U.S consolidated the will of the regime in Vietnam to adopt further policy reforms for WTO accession. In 2005, one year before Vietnam officially became a member of the WTO, a large number of laws including the Law on Enterprises and Investment Law were passed. With the radical legal change to harmonize 
investment/registration procedures and establish an equal playing field for all foreign

and domestic enterprises, Vietnam was admitted to WTO in November 2006.

The following Table 10 provides a summary of the changes that occurred in

the path toward the liberalization of trade policy in Vietnam from 1986 to 2006.

Table 10: Timeline of Vietnam's accession process to WTO

\begin{tabular}{|c|c|c|c|}
\hline No & Date and Time & Events & Policy Implications \\
\hline 1 & 1986 & $\begin{array}{l}\text { The VI National Party Congress of } \\
\text { Vietnam officially adopted } \\
\text { Renovation Program - Đổi Mới }\end{array}$ & $\begin{array}{l}\text { Marked a shift from a closed and } \\
\text { central-planning economy to a } \\
\text { "Socialist-oriented" market economy }\end{array}$ \\
\hline 2 & 1995 & $\begin{array}{l}\text { The WTO accepted application of } \\
\text { Vietnam and established Working } \\
\text { Commission on Vietnam. } \\
\text { Vietnam joined the ASEAN Free } \\
\text { Trade Area (AFTA). }\end{array}$ & $\begin{array}{l}\text { Vietnam submitted the WTO } \\
\text { Application Document in January, } \\
1994 \text { and became an observer of } \\
\text { WTO since } 1995 .\end{array}$ \\
\hline 3 & 1996 & $\begin{array}{l}\text { - Circulated a Memorandum on the } \\
\text { Foreign Trade Regime } \\
\text { - Started negotiation with the US } \\
\text { on the Bilateral Trade Agreement. }\end{array}$ & $\begin{array}{l}\text { Followed by a period of questions } \\
\text { and answers beginning in March } \\
1998 \text { to clarify Vietnam's politics } \\
\text { and institutions. }\end{array}$ \\
\hline 4 & 1998 & $\begin{array}{l}\text { Vietnam became a member of } \\
\text { Asian Pacific Economic } \\
\text { Cooperation (APEC). }\end{array}$ & $\begin{array}{l}\text { In the midst of VNUSBTA } \\
\text { negotiations. }\end{array}$ \\
\hline 5 & 1999 and 2000 & $\begin{array}{l}\text { Most of the technical issues of the } \\
\text { BTA with U.S were approved by } \\
\text { both sides and the BTA was } \\
\text { supposed to be signed in } 1999 \text {; yet, } \\
\text { there was a deadlock in which the } \\
\text { Vietnamese Party and government } \\
\text { agonized over whether the } \\
\text { completed agreement should be } \\
\text { formally concluded. } \\
\text { - In November, 1999, China signed } \\
\text { the BTA with the U.S. } \\
\text { - The VNUSBTA was finally } \\
\text { signed on July 13, } 2000 \text {. }\end{array}$ & $\begin{array}{l}\text { Even in the last months before } \\
\text { signing the agreement in July } 2000 \text {, } \\
\text { there was "an intensive period of } \\
\text { analysis and soul-searching" within } \\
\text { the highest levels of the Vietnamese } \\
\text { Party and government in which the } \\
\text { defenders of inefficient state-owned } \\
\text { enterprises and those concerned with } \\
\text { "security" clashed with the free } \\
\text { traders. }\end{array}$ \\
\hline 6 & $\begin{array}{l}\text { November } 28 \\
2001\end{array}$ & $\begin{array}{l}\text { The Bilateral Trade Agreement } \\
\text { with the U.S. was signed by the } \\
\text { National Assembly after the U.S. } \\
\text { President signed the BTA on } \\
\text { October } 18,2001 \text {. } \\
\text { The VNUSBTA came into effect } \\
\text { on } 10 \text { December } 2001 \text {. }\end{array}$ & $\begin{array}{l}\text { While application to the WTO was } \\
\text { initially made in } 1995 \text {, virtually no } \\
\text { major progress toward accession was } \\
\text { made until } 2001 \text {, after the } \\
\text { Vietnamese Communist Party at the } \\
\text { highest levels made the political } \\
\text { decisions necessary to open the } \\
\text { market, initially by signing the } \\
\text { VNUSBTA. }\end{array}$ \\
\hline 7 & $\begin{array}{l}\text { December 11, } \\
2001\end{array}$ & $\begin{array}{l}\text { China became a member of the } \\
\text { WTO. }\end{array}$ & $\begin{array}{l}\text { China action became an impetus for } \\
\text { Vietnam's accession to the WTO }\end{array}$ \\
\hline 8 & $\begin{array}{l}\text { December } 10^{\text {th }} \text {, } \\
2003\end{array}$ & $\begin{array}{l}\text { The WTO Working Party started } \\
\text { negotiating the terms of Vietnam's } \\
\text { membership }\end{array}$ & $\begin{array}{l}\text { From this point of time, Vietnam } \\
\text { stood firm on its will to join WTO } \\
\text { soon. }\end{array}$ \\
\hline 9 & 2005 & $\begin{array}{l}\text { The Vietnamese government tried } \\
\text { to conclude the negotiations for }\end{array}$ & $\begin{array}{l}\text { However, Vietnam ran into } \\
\text { difficulties in negotiation with the }\end{array}$ \\
\hline
\end{tabular}




\begin{tabular}{|c|c|c|c|}
\hline & & $\begin{array}{l}\text { WTO accession. } \\
\text { By this time, agreements with } \\
\text { many major players, including the } \\
\text { European Union, Japan, China, } \\
\text { and Canada were reached. }\end{array}$ & $\begin{array}{l}\text { United States, despite President } \\
\text { George Bush's promise of } \\
\text { collaboration on WTO negotiation, } \\
\text { made during Prime Minister Phan } \\
\text { Van Khai's June visit to the United } \\
\text { States. These difficulties dashed } \\
\text { Vietnam hopes for WTO accession in } \\
2005 .\end{array}$ \\
\hline No & Date and Time & Events & Policy Implications \\
\hline 10 & December, 2005 & $\begin{array}{l}\text { Vietnam missed its primary target } \\
\text { date for admission at the Hong } \\
\text { Kong WTO Ministerial Meeting in } \\
\text { December } 2005 \text { and had to settle } \\
\text { instead for the beginning of } 2007 \text {. }\end{array}$ & $\begin{array}{l}\text { Vietnam demonstrated a proactive } \\
\text { attitude the accession to WTO: in } \\
2005 \text {, a number of radical legal } \\
\text { reforms were made in response to the } \\
\text { requirements from WTO }\end{array}$ \\
\hline 11 & In 2006 & $\begin{array}{l}\text { The last bilateral agreements are } \\
\text { with Mexico in April } 2006 \text { and the } \\
\text { United States in May } 2006 .\end{array}$ & \multirow{4}{*}{$\begin{array}{l}\text { To cope with anticipated } \\
\text { international competitions and } \\
\text { pressures after being a member of } \\
\text { WTO, Vietnam started to establish } \\
\text { giant state economic groups in key } \\
\text { economic areas and consolidated the } \\
\text { existing state-owned enterprises. }\end{array}$} \\
\hline 12 & November 7, 2006 & $\begin{array}{l}\text { Vietnam was officially admitted } \\
\text { by the WTO Council at the APEC } \\
\text { Summit in Hanoi. }\end{array}$ & \\
\hline 13 & $\begin{array}{l}\text { November } 28, \\
2006\end{array}$ & $\begin{array}{l}\text { WTO accession was approved by } \\
\text { the National Assembly. }\end{array}$ & \\
\hline 14 & January 11, 2007 & $\begin{array}{l}\text { Vietnam officially became the } \\
150^{\text {th }} \text { member of WTO. }\end{array}$ & \\
\hline
\end{tabular}

\section{The potential benefits and challenges in liberalizing Vietnam's trade policy}

This section will review the major pros and cons that provided the background for the debate over the liberalization of Vietnam's trade policy. It will help the reader with a better understanding of circumstances, in which the Vietnamese Communist Party and government had to calculate the balance between the political interests and the economic health of the regime.

\section{Potential benefits from international trade agreements}

In theory, Vietnam's trade agreement with the U.S. and then its accession to the WTO was expected to help Vietnam sustain the economic growth of the first decade after Đổi Mới, especially after the occurrence of the Asian Financial Crisis in 1997. Scholars who have studied Vietnam liberalization of trade policy have identified at least five major benefits of trade liberalization for Vietnam. 
First, entry into the WTO was expected to boost industrial production as exporters are given quota-free access to the global market, which was expected to result in projected annual GDP growth rate of around 10 percent (Chu \& Dickie, 2006). The second anticipated benefit of trade liberalization was a large increase in Vietnam's imports and inward FDI. In hindsight, it is not clear that WTO accession has directly encouraged Vietnam's exports. However, with a strong bidirectional relationship between FDI and exports, WTO accession might have indirect influences on Vietnam's exports through the FDI channel (Pham, 2011). Facilitated by FDI inflows, significant new markets would be opened up in the United States and Europe for products from Vietnam, especially in the face of declining exports to Asian countries after the Asian Financial Crisis in 1997.

Third, WTO membership and bilateral agreements were expected to give Vietnam a higher status in international relations with foreign partners and countries. As a member country, Vietnam would have permanent and unconditional MFN offered by other WTO member countries and would be provided with access to a dispute settlement mechanism (Nguyen \& Haughton, 2002). Vietnam would have a stronger voice and more credibility to resolve commercial disputes with other countries such as the catfish price-dumping dispute with the U.S.

The fourth potential positive impact of international trade liberalization is that it would foster domestic legal and governance reforms. To join the new playing field, the Vietnamese government would have to accept a variety of legal changes that might be very beneficial in the longer term (Chu \& Dickie, 2006). For example, a move towards a greater uniformity in tariff rates might help in reducing delays and corruption involved in customs procedures (Athukarola, 2006). Further adjustments in 
investment and business laws and reforms in state-owned enterprises, financial and banking sectors and in human resource development would help Vietnam sustain high long-run growth rate and income improvements.

Fifth, trade liberalization would force Vietnam's domestic industries to adjust to full international prices, which in turn would encourage international competitiveness for the entire economy (Chu \& Dickie, 2006). Full implementation of the Association of Southeast Asian Nations Free Trade Area (AFTA) Agreement in 2006 and the bilateral trade agreements under World Trade Organization (WTO) accession might increase the competitiveness for domestic products and services and required more restructuring of the domestic economy (Luong, 2006; Nguyen \& Haughton, 2002). Although international competition might adversely impact domestic firms in the short term, in the long run it would help domestic firms, especially the state-owned enterprises, restructure, find their niches, and increase efficiency.

In the bottom line, free trade would help Vietnam take advantage of its lowcost labor force, abundant natural resources, favorable geographic location, and a large proportion of young workers. The potential economic gains of the Bilateral Trade Agreement with the U.S and then accession to WTO were expected to be sufficiently strong to motivate the Vietnamese negotiators to reach quick agreement (Luong, 2006). The sustainability of economic growth, in turn, would help the regime sustain its political legitimacy and social stability, which was being challenged by incidents of social unrest in 1997. However, this is just one side of a coin. Along with the potential benefits, Vietnam would face many challenges upon becoming a full member of the international economic community. 


\section{Challenges to Vietnam when deeper liberalization of international trade}

In order to participate in both bilateral and multi-lateral international trade agreements, Vietnam would need to accept equal treatment of both domestic and foreign firms, reduction in the import taxes and abolishment of quotas for most of the commodities from abroad. The challenges arising from deeper international economic integration are summarized in greater detail in the paragraphs that follow.

First, many expressed concern that obligations in trade agreements might increase competitive pressures on local firms. For example, Viet Nam would have to remove subsidies to the garment industry and some agriculture sectors. While this can be viewed as an advantage in the long run, in the short run there would be unknown and perhaps extensive dislocations of many local businesses (Chu \& Dickie, 2006). Impacts on small and medium size private domestic enterprises as well as a weakly competitive state-owned sector raised concerns about the possible collapse of the whole domestic economy. This challenge, in turn, might risk state control and increase political instability within the country.

Another concern that was raised about trade liberalization was whether the Vietnamese exporters would be able to compete in the globalized market with their rivals in other WTO members, especially those from China. For example, one research report predicted that the export growth rate of Vietnam might fall from its 2005 pace of more than 22 percent to 19 percent in 2008 as the impact from WTO membership was felt, especially with regard to the loss of subsidy programs for textile producers (Chu \& Dickie, 2006). At the same time, continued rapid growth of the domestic economy at 8 percent in real terms would result in an acceleration of imports from an estimated 16 percent in 2005 up to nearly 20 percent in 2008 . As a result, the 
current account deficit was expected to grow from near balance in 2005 to a deficit of US\$2.8 billion in 2008 (Chu \& Dickie, 2006).

A third concern of trade liberalization was that the Party and government would have to accelerate critical governance reforms, including: (i) administrative procedure reform, (ii) removal of restrictions to trade, and (iii) harmonizing of the legal system with the fundamental principles of international law (Pham, 2011). Among the most important reforms in administrative procedure was tariff reform that would include: reduction of tariff rates, introduction of a duty drawback system and the adoption of the Harmonized Tariff System. These administrative and legal reforms would require strong political commitments by the Party and government to delegate many of its powers and authority to the market forces. This decentralization, in turn, was thought by some to adversely affect the political control and leadership of the Party over the society (Kerkvliet, 1995 \& 2001).

Fourth, even though liberalization in trade and WTO accession might play an important role in attracting FDI as well as in encouraging Vietnam's imports, deeper integration into the globalized market could make Vietnam more vulnerable to a financial crisis or a global economic slowdown in the future (Pham, 2011). For example, the Asian Financial Crisis in 1997 intensified debate within the leadership of the CPV about the best way for Vietnam to deepen its reforms and the pace of international integration. Conservatives within the CPV were inclined to attribute the serious impacts of the 1997 crisis on other Asian countries to their deep dependence on international markets (Dinh Q. X., 2000). Such views were likely to affect the debate over the pace and degree of trade liberalization. 
In short, while trade liberalization appeared to bring clear economic advantages to a country like Vietnam, the discussion of multiple political and economic factors that needed to be taken into account made such a decision much more problematic than it first appeared. The choice for political leaders was not simple. Political stability of the country was of great concern because of the close interconnection between state-owned enterprises, the Party and the overall functioning of the economy. As the result, trade liberalization was somewhat of a paradox: while the leaders of the regime wanted to strengthen the economy and improve the quality of life, their view of how and when to do so was divided. This paradox was strongly reflected in the policy process when Vietnam negotiated the bilateral agreement trade with the U.S. The following section will explore this process in detail to elucidate the paradox.

\section{Case analysis: how did policy factors influence the outcomes?}

Vietnam started its negotiation with the U.S. on the bilateral trade agreement in 1996. Some may assume that the BTA with the U.S was an inevitable consequence of Vietnam's commitment to economic reforms initiated in 1986, especially after it joined the ASEAN Free Trade Area (AFTA) and applied for WTO membership in 1995. However, the negotiation process was accompanied by strong internal debate within the Party and government about whether and how fast to proceed. This debate produced a deadlock in negotiations from 1999-2000. Indeed, by the middle of 1999, most of the important technical issues had been resolved and the BTA was ready for signing at the $7^{\text {th }}$ APEC Summit in New Zealand, in September 1999 (Nguyen D. L., 2010). However, at the last minute, the highest leadership of the Party decided not to sign the agreements. For nearly one year, further deliberation and education took 
place within the highest body of the Communist Party and, finally, consensus was reached to move forward with this critical but controversial trade agreement. The BTA was signed in July 2000, and Vietnam needed one more year before the National Assembly officially ratified the agreement in November 28, 2001, only one day after the Party Central Committee of Vietnam promulgated a special Party Resolution on International Economic Integration.

In this section of the chapter, I will use the policy change factors identified in my proposed major policy change model presented in Chapter III to shed light on the internal party and government deliberation over the liberalization of Vietnam's trade policy. My model advances the following three propositions:

- Only when facing significant stressors, does the Vietnamese regime seek and adopt radical policy change in response to the stressors. Together with stressors, the leadership predisposition to reform is the precondition for the advancement of radical policy change in the politics of Vietnam.

- Significant change will not occur without a shift in the policy image held by party leaders (i.e., what is the origin of the policy problem and the corresponding solutions?).

- Due to the collective and consensus-based decision making style and the principle of democratic centralism of the Vietnamese regime, a radical policy change initiative will only be adopted when it is congruent with the expressed political priorities of the Party that are held at a given period of time. This proposition means that party judgments can trump the technical arguments for radical change. 
In the following sections, I will seek to determine whether each of the above propositions is true in the case of changes in Vietnam's trade policy.

\section{The role of stressors in accelerating trade reforms}

The Asian Financial Crisis in 1997 devastated the economies of most Asian countries, especially those of South Korea, Thailand, Indonesia, and Malaysia. However, compared to its ASEAN neighbors, Vietnam appeared to have weathered the crisis quite well (Kokko, 1998). Official statistics indicated a GDP growth rate of 5.67\% for 1998 (Nguyen H. T., 2007). This growth rate was much higher than other Southeast Asian countries. Export growth remained positive, and the Dong currency depreciated by only $20 \%$ against the USD after the crisis, which was acceptable compared to other Asian countries (Kokko, 1998).

However, the relatively favorable picture has more to do with controls than with sound economic fundamentals. Key economic indicators gradually revealed a sharp decline compared to the pre-crisis period. Indeed, Vietnam's GDP growth was halved, from $9.5 \%$ in 1995 to $4.8 \%$ in 1999, the lowest level since Đổi Mới (Nguyen H. T., 2007). This slowdown had negative effects on employment and poverty with unemployment in urban areas estimated at $7.4 \%$ for 1999 , while underemployment in rural areas was reported at 28.2\% (Dinh Q. X., 2000). Even if the GDP growth had resurged to $7 \%$ per annum, the peak experienced in the rapidly growing Asian economies prior to the financial crisis of 1997 , it would still take at least three decades for Vietnam per capita income to reach the current levels in neighboring Thailand (Nguyen \& Haughton, 2002). By the end of the 1990s, Vietnam was still one of the poorest countries in the world (with a per capita income of U.S. \$350 per annum). By the standards set by the government of Vietnam, at that time, some $37 \%$ of the people 
were considered poor, with an income less than $\$ 128$ per person per year, and over $40 \%$ of children less than 5 years of age were malnourished (Dinh Q. X., 2000). Slower rates of growth along with pressure from rural disturbances and growing dissent (social chaos in Thai Binh province in 1997) pressed the Party and government to take urgent actions to improve the living standards of the people, especially the poor.

On another front, foreign investment declined sharply over the first four years following the 1997 financial crisis, descending to the lowest level in 1999 and 2000. Implemented foreign direct investments had fallen from a peak of approximately two (2) USD billion in 1996 and 1997 to around 600 million USD in 1999 and 2000 (Nguyen H. T., 2007). Two main factors adversely affected FDI flows to Vietnam: (1) the Asian financial crisis of 1997 reduced FDI from other Asian countries to Vietnam, and (2) the FDI-diversion into China resulting from its bilateral trade agreement with U.S. and a foreseeable entry into the WTO (Nguyen \& Haughton, 2002). The decline in FDI was a major impediment to the government's goal to attract massive foreign investments in transportation, energy and telecommunication. By 2000, the required investments were estimated at 3.4-3.9 billion USD (World Bank, 2000, cited in Nguyen \& Haughton, 2002) of which a large part was expected from FDI.

In terms of international trade, Vietnam faced fierce competition from the products of other Asian countries after these countries depreciated their currencies in response to the 1997 financial crisis. This widespread depreciation made products from other Asian countries relatively cheaper than the same products manufactured in Vietnam. In addition, without international trade agreements, exports from Vietnam suffered from high import taxes and quotas by other countries. Chinese exports were 
an especially significant stressor. For instance, Vietnam's garment exports remained subject to quota in the U.S. market. By contrast, China with the BTA agreement with the US since 1999 and WTO membership since 2001 benefited from the removal of textile and garment export quotas. At the turn of the century, Vietnam was one of only a handful of countries that did not have permanent normal trade relations (PNTR) with the United States. Increased American investments and favorable access to American markets through the granting of PNTR would have helped Vietnam arrest the erosion of the economy which became increasingly slowing-down after the regional crisis in 1997. According to the World Bank, the reduction in U.S. tariffs by as much as $40 \%$ would have quickly raised the revenues of the Vietnamese exports to the United States to $\$ 800$ million from the 1999 level of $\$ 500$ million (Pierre, 2000).

Finally, the lack of comprehensive tariff reform added another stress to the economic drivers of change. By the end of 1990s, Vietnam's tariff structure was still out of line with the general patterns of the ASEAN countries and China (Athukarola, 2006). Tariffs are still high and non-uniform. The effective rate of protection for traded goods (manufacturing, in particular) has recorded a significant decline over time. Moreover, higher import duties on intermediate goods had make the products produced in Vietnam more expensive than the same products from other countries.

In the face of the above difficulties, the Resolution of the IV Plenum of the Party Central Committee under the VIII National Party Congress in December 1997 admitted that "the internal weaknesses of the economy, especially the low quality and efficiency of development, low competitiveness of domestic products and the new difficulties rising from the impact of the ongoing financial crisis in the region and the world is a big challenge for us to realize the goals of the socio-economic development 
plan till 2000" (Communist Party of Vietnam, 1997). In 1998, Prime Minister Phan Van Khai stated publicly that "the lowest rate of economic growth since 1990," was causing stockpiles of unsold goods and poor competitiveness at a time when "foreign investment is low and unemployment is serious, resulting in social evils" (Nguyen H. M., 2000).

To summarize, there was evidence of great pressure on the Vietnamese government to deal with economic slowdown after the Asian Financial Crisis in 1997. In the absence of comprehensive reforms, the Vietnamese economy would gradually slide into a deeper recession (Kokko, 1998; Nguyen \& Haughton, 2002). In 1999, slow growth and increases in unemployment in the two years after the Asian Financial Crisis, along with the impact of floods in several provinces, put pressures on the government to push for further and deeper reforms (Dinh, 2000; Nguyen \& Haughton, 2002). The gains from the initial reform beginning in the end of 1980 s were nearly exhausted, requiring a second phase of reforms to induce high growth of the industrial sector from increased FDI and exports (Kokko, 1998; Nguyen \& Haughton, 2002; Chand, Duncan, \& Quang, 2001). Given the severe deterioration in Vietnam's economic situation, the trade agreement was the most likely effective solution to reverse the economic decline (Pierre, 2000).

In this regard, two scenarios of policy direction seem possible: (1) a return to stricter government control over the economy and tougher political repression, or (2) a new round of economic reforms, a Đổi Mới II (Kokko, 1998). The first scenario based on a return to central planning and political isolation was preferred by influential interest groups, such as SOEs and their supporters (Kokko, 1998). The alternative scenario was to increase outward orientation and structural reforms to 
improve the efficiency of the economy. Such reforms would necessarily have to reach beyond incremental policy change, for example, the adjustment of the exchange rate to make exports more competitive. Đổi Mới II would need to include measures to simplify and liberalize the trade regime, strengthen the financial system, reform SOE management and promote private enterprises, and increase transparency at all levels of the economy (Kokko, 1998). While stressors were certainly influencing party and government leaders, it is important to see if these stressors were received with a strong leadership predisposition to radical change in trade liberalization before the BTA with U.S was accepted. The next section will examine this important change factor identified in the major policy change model discussed in Chapter III.

\section{Leadership predisposition to radical change in international trade}

The economic stressors discussed in the previous section illustrate increasing both internal and external pressures on Vietnam to speed up its integration into the world economy, especially after the Asian Financial Crisis in 1997. But the question here is: did the Party and Government of Vietnam demonstrate their leadership predisposition to reform international trade policy? The answer is "yes". Indeed, there had been important evidence of the leadership predisposition to liberalize its trade regime starting with the decision to join the Association of Southeast Asian Nations Free Trade Areas (ASEAN-AFTA) in 1995 right after Vietnam normalized its diplomatic relationships with many countries in the region and the world. In becoming a member of AFTA, Vietnam agreed to reduce the average import tax to $5 \%$ for products from all member countries by 2006. In the same year, Vietnam initiated its negotiation with the United States for the BTA in October 1995. A second important sign that there was a predisposition by leaders to change occurred in 1995 
when the Vietnamese government submitted an application to join the WTO and expressed its desire to meet its goal of WTO membership by 2005. The Five-year Socio-economic Development Plan promulgated by the Party Central Committee in 1996 produced at the VIII National Party Congress in 1996 demonstrated the predisposition of the Party to become a more important member of the global market economy. For example, the Development Plan urged for acceleration in economic integration into the region and the world by setting the target of an average annual export and import growth of $28 \%$ and $24 \%$ respectively in five years of the plan. Also in five years, the country was supposed to attract 13-15 billion USD through the FDI channels (Communist Party of Vietnam, 1996).

In 1997, right after the occurrence of the Asian Financial Crisis, the Party Central Committee of Vietnam in its Resolution of the $4^{\text {th }}$ Plenum under the VIII National Party Congress clearly expressed its emphasis on export promotion and international trade liberalization. The third solution in the resolution pointed out that:

It is important to encourage and create the most favorable conditions for export and import by clarifying a small number of prohibited products for export and quotalimited import products. The procedures for exportation must be simplified. All registered firms are allowed to export and the quota limits are replaced by a tariff system.

Also, the fourth solution emphasized creating an equal status for both domestic and foreign companies and applying an integrated tariff, price and service fee system for every kind of enterprise. These administrative reforms were intended to compete for the FDI with other countries in the region and promote exports.

Especially, in the solution number five, the Resolution emphasized a "proactive and positive attitude to penetrate and expand into the international market". 
More concrete, the Party urged for the need to "be proactive to prepare for necessary conditions in terms of negotiating official, legal framework and especially fostering competitive products in order to integrate into regional and world markets; and conduct quick and solid negotiation for BTA with the U.S, participate in APEC and WTO” (Communist Party of Vietnam, 1997).

In terms of legal reforms, the Vietnamese government showed its commitment to simplify regulatory procedures as a condition for the BTA with the U.S. First, the Import and Export Duties Law was revised in 1998, which helped integrate and systematize tariff practices. The Law on Foreign Investment of 1996 was revised in 2000 and the Law on Domestic Promotion was promulgated in 1998. Also, the Enterprise Law was adopted for the first time in 1999 to establish a common set of rules for all types of private enterprises. Especially, the year 2001 witnessed a major positive shift in trade policy in which a tariff reform roadmap for the period 2001-05 under the Decision 46/2001/QD-TTg in April 2001 was announced, creating a more transparent and predictable export-import environment in Vietnam. In particular, most quantitative restrictions were removed in 2001 ahead of schedule and at that time there were only two products, namely petroleum and sugar, subject to quantitative restrictions (Vo \& Nguyen , 2009).

To summarize, since 1995, Vietnam had shown its desires for comprehensive trade liberalization by joining AFTA, accelerating trade negotiation with the WTO and with the U.S. In 1996, the Five-year Socio-economic Development Plan 19962000 directly pointed to the intention to join the WTO and other international economic institutions. However, the document did not directly discuss the BTA with the U.S. After the occurrence of the Asian Finance Crisis starting from 1997, the 
leadership predisposition to trade liberalization reform was intensified by the Resolution of the $4^{\text {th }}$ Plenum under the VIII National Party Congress, which directly pointed to a quick negotiation for BTA with the U.S. In November 2001, the CPV released the specially Resolution No. 7 on International Economic Integration which confirmed the irreversible path for Vietnam to fully integrate in the world economy. Nonetheless, the BTA with U.S was a sensitive and controversial issue that caused contentious deliberation within the highest organs of Party and government about the pace and scope of international economic integration. To adopt the BTA, the policy image had been changed to pave the way for consensus within the Party and government. The following subsection will examine in detail how the policy image of the policy elites in this trade domain was changed.

\section{Change in policy image of the regime to the BTA with the U.S}

The above discussion provides strong evidence to support the conclusion that the political leaders of Vietnam exhibited awareness of external stressors requiring major policy changes in trade liberalization with a strong predisposition to embrace the need for these changes. But as I pointed out in the discussion of the major policy change model in Chapter III, these causal factors may not be enough to bring change about if the policy images of the Party and government regarding the technical feasibility of the policy change initiative have not changed. Thus, it is important for the policy elites in the Party and government to change their perception of the role and consequence of the BTA with US. Persuasive technical and economic arguments for change would pave the way for the BTA to reach the consensus within the Party for final approval and adoption. 
In exploring the policy image of the policy elites on the BTA with U.S, I will rely heavily on a series of interviews with the heads and senior officials of the two Vietnamese and U.S. negotiation delegations. The web-based newspaper TuanVietnam.net conducted the series of interviews in July 2010 with four people. On the Vietnam side, the interviewees were Mr. Nguyễn Đình Lương, the head of delegation, and Mr. Mai Liêm Trực, the then Director of the General Department of Postal Services who was in charge of the negotiation on telecommunication markets. On the U.S. side, the interviewees were Joe Damond, the chief U.S. negotiator for the BTA and Virginia Foote, President of the U.S.-Vietnam Trade Council. These officials were the representatives of the two governments and had been working closely with each other from the beginning to the end of the negotiation process.

A careful examination these interviews reveals the following three sets of factors related to the policy image of the Vietnamese policy elites that greatly influenced the process and substance of the BTA negotiations with the U.S side: (1) the obsession with the Vietnam War; (2) the role of national interest; (3) the reassessment of the potential BTA consequences. The role of each of these three factors will be discussed in greater detail in the sections to follow in order to elucidate how the policy images of the elites had been changed overtime.

\section{Obsession of the War}

According to Nguyễn Đình Lương, the Head of the Vietnamese Delegation, the negotiation between Vietnam and U.S. was undertaken against the common backdrop of a shared legacy of being recent warring countries. It is not like the cases when the former communist Eastern European countries negotiated the BTA with the U.S as a step in a larger process of joining the EU and NATO. It is also different from 
other developing countries, which considered negotiating BTA agreements with the U.S. as an opportunity to expand their national development and influence into the international community. Vietnam "has her own circumstances, calculations and negotiation principles and had to overcome very unique barriers on her own" (Nguyen D. L., 2010).

Since the early 1990s, Vietnam had expressed its willingness to diversify both bilateral and multilateral relationships and be a friend with all nations in the world for the sake of peace and development. However, this commitment did not mean that the negotiations with the U.S. would be smooth and easily reach consensus. Differing from the previous negotiations, these negotiations were a first step in rebuilding mutual understanding and trust with the Americans. However, Mr. Lương admitted, "At the starting point, we did not have such things". He continued, "The war had brought miseries and sorrows for my family. Our generation is loyal to the teaching of Uncle Ho: Fight to kick the Americans out” (Nguyen D. L., 2010).

Thus, the psychology on the Vietnamese side at that time was colored by anger at America and the lack of trust. Mr. Lương posited that even though Vietnamese history was the history of war, there had not been any war like this before, as brutal and devastating. None of the cities in Vietnam were intact and almost every family in Vietnam had someone who had been lost in the war. The pain was not just in Vietnam, it was also a political disaster for Americans as Mrs. Virginia Foote, the President of US-Vietnam Trade Council asserted: "The war is still around...Some politicians, senators, and people in the US still do not want to normalize relation with Vietnam" (Foote, 2010). 
As the result, mutual suspicion resulting from the past war overshadowed the negotiations. The brutality and devastation of the war made the Vietnamese people and leaders worry about the possibility of the "return of Americans to their land". By that time, Vietnam still considered America as a "long lasting and essential enemy". Anti-American psychology had been infused deeply into every social class, even after Vietnam had normalized the diplomatic relationship with the U.S. in 1994 (Nguyen D. L., 2010). The difference in ideology made the mutual suspicions even greater; especially when the Vietnamese recalled the famous saying of Henry Kissinger "Americans did not win in the war but will do so in peace time".

So the first step for successful negotiations was to break the ice and gain mutual understanding and trust between the two sides. The Head of U.S. Negotiation Delegation, Joe Damond, observed, "Vietnam spent a lot time in determining whether they could trust what was being proposed by the American side. The American side always said that the Agreement would bring benefits to both sides" (Damond, 2010). But, Mr. Damond noted, "some Vietnamese thought that we were cheating". According to Mr. Lương, some people in the Vietnamese leadership group used the word "plot" to characterize the ideas proposed by the U.S. side. Some on the Vietnam side believed that the U.S. was using the BTA as a plot "to transform Vietnamese political regime" or "to destroy the socialism path in Vietnam" or "to destroy the Socialist-oriented economy of Vietnam". A big question was raised on the Vietnamese side: How can Vietnam partner with an "enemy"? This cautious attitude was strong within a group of leaders at the highest level of the Party and government and, as Mr. Lương posited "resulted in careful attention to every word and term in the BTA agreement” (Nguyen D. L., 2010). 


\section{The triumph of national interests over suspicion}

In the face of such high levels of distrust, how did the Vietnamese side overcome its suspicion and come to believe in the benefits of the BTA with the U.S? In fact, during about five years of negotiation, the conservative leaders of Vietnam were against the BTA and the reformers were in favor. While both proponents and opponents were patriotic, they differed in their understanding, view, and vision regarding the BTA. Mr. Lương observed that he underwent a change in thinking over the course of the negotiations. He gradually began to recognize that what Vietnam needed from him "was not the anger and suspicion", but to overcome such psychology on his own part and "to seek for opportunities and interests for the people and nation”. Both Mr. Lương and Mr. Trực asserted that without taking a much larger view of the overall national interests in negotiating the BTA, it would have been impossible to reach mutual agreements on the most important technical issues of the BTA by September 1999. Thus, pragmatic perspective had gradually triumph the suspicion in order for the Vietnamese side to move forward with the agreement.

\section{Reassessing the potential consequence of BTA to Vietnam}

In addition to pragmatism, in order to reach the agreements with the U.S. Delegation on the technical issues, the benefits and risks of the BTA had been taken into account and deliberated within the Party and government elites in the period from 1996 to 1999. At the beginning, the Vietnam delegation was worried about the adverse impacts that a globalized capitalist system would have on its Socialist objectives. Mr. Lương recalled that during the negotiation process, some Vietnamese leaders posited that: 
Signing the BTA with the U.S. based on the principles and rules of WTO means that we accept to participate into the process of globalization. We need to reexamine the class nature of the globalization process which is led by capitalism. If it is led by capitalism, it will only bring in benefits for the capitalist class. The less developed people will be poorer and the gap between the rich and the poor countries will grow larger. Should we wait for another globalization process led by the proletariats?

Some also argued that if Vietnam signed the BTA to allow the inward flow of money and products from the U.S., it could cause Vietnam to lose the control it needed to achieve a Socialist society. Mr. Lương remembered that some leaders of the Party asserted "if we lose the control over the flow of capital and products, we cannot build a Socialist society; thus, we must prohibit capitalists from coming into Vietnam and do their business" (Nguyen D. L., 2010). In the same manner, some suspected that "America is very rich and strong; their products are good and abundant. So if Vietnam opens its doors for American products, only after one week, or less, our economy will collapse" (Nguyen D. L., 2010). When dealing with agreements about copyright laws, some worried that "Commitment to copyrights means that we make difficulties for ourselves. Our country is poor, so we need to use the inventions of others to develop our country. How can we have money to buy copyrights?" (Nguyen D. L., 2010).

To change the above described policy image of some leaders in the Party and government and induce them to support the BTA, members of the Vietnamese Negotiation Delegation and other senior technocrats had to change their own beliefs first and then explain and persuade their leaders in the Party and government of the benefits of the BTA. Indeed, the early concerns about the adverse consequences of capitalism on the country's Socialist goals were gradually tempered by the collection 
and analysis of data and by the process of participating in the negotiation itself. Mr. Lương observed that he and others began looking at the experience of other countries that had signed the BTA with the U.S. and argued, "If such countries had trust in protecting their national interests while being trade partners, why couldn't Vietnam have similar trust in its self-governing capacity?" (Nguyen D. L., 2010). And that without actual integration and innovation, Vietnam will be backward forever. Gradually, representatives of the Vietnamese Delegation began to change their own thinking as they examined the experiences on international trade liberalization by other countries and reflected on their capacity to be controlling agents of their own destiny. As a consequence, after a long internal deliberation process and exchange of views, the members of the negotiation delegation and senior technocrats had changed their policy images. They then educated their leaders in the Party and government to make them recognize the BTA as the right direction for Vietnam to fully integrate into the world economy. The benefits and advantages would be much greater than disadvantages.

To summarize, it took time for the change in the policy image held by the policy elites and leaders in Vietnam in order for them to accelerate the negotiation process. Notably, reaching the agreements on the technicalities of the BTA with the U.S. side was very difficult; however, it was even more difficult to reach internal consensus within the Vietnamese Party and government (Nguyen D. L., 2010; Mai L. T., 2012). Many conferences, meetings and reports were conducted to educate the leaders in the Party and the government to make them believe in the benefits of the BTA. After much dialogue and discussion, collection and analysis of data and some 
concessions on the U.S. side, the Vietnamese side began to believe that "the BTA would make the economy of Vietnam stronger not weaker" (Damond, 2010).

The BTA negotiation process illustrates the important role that technocrats and specialized public officials play in Vietnam's policy process. Since these technical experts were responsible for the gathering of data and its analysis, they played a critical role in changing the universe of discourse during the negotiation process. However, as Mr. Nguyễn Đình Lương, the Head and Mr. Mai Liêm Trực, a key person of the Vietnamese Negotiation Delegation stated, they themselves were not in the position to finalize the BTA. In the middle of 1999 , most of the technical issues were accepted by both negotiation delegations and the BTA was ready to be signed at the APEC Summit in New Zealand in September 1999 between Vietnamese Prime Minister Phan Văn Khải and U.S. President Bill Clinton. However, the signing was postponed without any publicized explanation (Nguyen D. L., 2010). It was not until July 2000 that the BTA was signed. This raises the question of what was happening in the internal leadership of Vietnam during that time. Why did the Party and government delay signing the BTA after being convinced that doing so was a good thing on both policy and technical grounds? In the following section, I hope to shed light on this important question.

\section{Consensus on political priorities as the sufficient condition for radical}

\section{policy change}

The policy change model presented in Chapter III emphasizes the importance of obtaining party consensus on policy priorities even when there is agreement that policy needs to change and agreement on what that policy should be. Consensus on these technical issues and factors does not mean that agreement on these issues should 
be given first order priority at the moment over other political goals. For a radical policy change alternative to be adopted, the CPV leaders must reach the consensus on the temporary political goals that support the change alternative. As mentioned earlier, even though Mr. Lương and Mr. Trực were senior officials of the negotiation delegation, they were not in the position to decide the final outcomes of the negotiation process with the U.S. Mr. Trực recalled that at that time the Vietnamese Negotiation Delegation wanted to sign the BTA with the U.S. before China signed the same BTA with the U.S. However, this intention was not allowed by the highest organ of the CPV (Mai L. T., 2012).

In Vietnam, the technocrats were in charge of technical issues and always needed to report to leaders of the Party and government to obtain a final decision from the highest levels of the Party, including the Party Central Committee and the Politburo. Within the Politburo, the process of reaching consensus among its members is complicated and political in nature. To explain why the BTA was delayed from September 1999 when it was supposed to be signed until July 2000 when it was signed, I will draw from the following three bodies of research: (1) Vietnam's Contradictions by Andrew J. Pierre (2000); (2) The Lessons of Le Kha Phieu: Changing Rules in Vietnamese Politics by Zachary Abuza (2001); and (3) Vietnam in 1999: The Party's Choice by Nguyen Manh Hung (2000).

\section{Conflict of values within the Party leadership}

After the Asian Financial Crisis (1997), the Vietnamese Party and government were faced with two different choices: (1) continue with the direction of placing priority on political stability and accepting only incremental change at the expense of urgent economic reforms and sustainable growth; or (2) undertake comprehensive 
economic reform including trade liberalization and signing of the BTA with the U.S. The proponents for the former were conservative leaders in the Politburo who perceived that radical change would entails many risks, including unemployment in the public sector, SOE divestitures, and possible social unrest (Dinh Q. X., 2000). In contrast, the reformers advocated the later choice, which necessitates broader institutional and political reforms. They perceived that although the BTA might induce short-term difficulties but it would strengthen Vietnam's long-term development prospects.

\section{The conservative view}

The conservative members of the leadership group in Vietnam were strong believers in socialist orthodoxy. After a lifetime of belief in and struggle for MarxismLeninism, they were uneasy about the market economy and trade liberalization. Thus, they had and continued to have a strong preference for a "Socialist-based market economy" that conforms to Socialist ideology and practices. Even though they think that the country needs to attract resources from outside, they feared that ideas such as democracy, human rights, civil society, good governance, and so on, would infiltrate the country and undermine Communist Party dominance (Pierre, 2000). The conservative leaders believed that the market economy, albeit with a Socialist orientation, might distract the country from the Socialist path and risk the control and leadership of the Party over the economy and the whole society. They were afraid of the threat of peaceful evolution (a code for the capitalist/imperialist menace) through free trade and the creation of a market economy. The conservatives were composed of a broad group of party ideologues, security apparatus and military members, and SOE directors, with "impeccable class backgrounds" but with minimal exposure to the 
outside world and the running of a market economy (Pierre, 2000). For example, the conservative members were reluctant to equitize the SOEs and did not want to open the domestic market for international competition due to the weak competitiveness of the SOEs. Thus, the main beneficiaries of protectionism were SOEs. For conservatives, the SOEs and state control over the economy offer the possibility of prolonging the CPV's control. They have significant political and economic power, and might be able to retard trade liberalization because they have grown accustomed to a protected economic environment (Pierre, 2000). Thus, the conservatives tended to support the political status quo and policy stability instead of radical economic reforms.

\section{Reformer's view}

In contrast, pragmatic reformers argued that in order to sustain development, Vietnam required rapid change to catch up with neighboring countries. They had worked with, and been exposed to the outside world and most of them belong to the executive branch (for example, the late Prime Minister Võ Văn Kiệt). That does not mean that the reformers did not believe in the core values and priorities of the Party: Party leadership and a Socialist state. However, they differed from the conservatives in pressing for the efficient functioning of the political and economic system rather than the survival of ideology (Pierre, 2000). The reformers represented a group of technocrats, senior party members, and senior policy makers, advocating change. They hoped that a well-developed system of governing institutions might evolve as ideology grew less important, thus facilitating Vietnam's economic development. As Đổi Mới has taken root and the political system became more open, the reformers gained a larger support base from the growing group of technocrats, western-educated 
people and reformers or retired senior party members. Thus, the reformers wanted Vietnam to join the global market to cultivate its strengths (such as low labor price, young population, and advantageous geographic location) and facilitate its long-term development prospects.

\section{Leadership deficiency in economic reforms in 1999}

After a new leadership generation took greater power during the second half of 1997, the conservatives and reformers were split over the extent and pace of reform (Dinh Q. X., 2000). The main difference between them was how much risk Vietnam should take in continuing with the process of reform, including the BTA with the U.S. This led to a debate over what constitutes a "market economy with socialist orientation" in Vietnam's development strategy and produced a reluctance to discuss the comprehensive reforms in trade liberalization with the "old capitalist enemy" - the United States - which would be considered a "deviation from the Socialist-based market economy" (Dinh Q. X., 2000).

Because each leadership group interpreted the BTA differently and embraced different priorities, further discussions were required, thus delaying the achievement of consensus. As a consequence, the implementation of reforms slowed down and no consensus was reached to finalize the BTA with the U.S. from the second half of 1997 to the middle of 2000. All leaders did agree on the need to continue with change, but there was debate over how much the party should risk deeper reforms. It was the pace of reform that became the main point of contention rather than differences over the substance or the direction of the reforms (Dinh Q. X., 2000).

According to an in-depth research of Zachary Abuza (2001), Prime Minister, Phan Văn Khải raised the alarm on the economic downturn in 1999, but the Politburo 
was bitterly divided along factional and ideological lines and unable to come to an agreement on the advancement of the reform program. There was no consensus within the politburo on which steps to take. Reformers understood that economic growth was contingent on exploiting Vietnam's comparative advantage, joining the global marketplace, attracting foreign investment and engaging in trade. In contrast, ideological conservatives, such as the Party General Secretary, Lê Khả Phiêu, saw international trade and globalization as ways that the first world would continue to exploit Vietnam and keep it poor and underdeveloped. He warned that "When imperialism speeds up trade and services liberalization and the globalization of investments, the rich countries become richer and the gap between rich and poor countries widens" (Abuza, 2001).

A serious leadership and decision-making vacuum in the CPV increasingly complicated the ideological divide between the conservative and liberal wings of the CPV during the 1999-2000 period. Scholars studying this period are in agreement that Party General Secretary Lê Khả Phiêu provided no strong leadership in response to the economic downturn after the crisis and no leadership to bridge the division within the leadership organs of the CPV (Pierre, 2000; Abuza, 2001; and Nguyen, 2000). Mr. Phiêu was unable to close the gap between the conservative and liberal positions and to form a consensus policy to move forward further economic reform, including the BTA with the U.S. As a result, in the midst of continuing economic recession in 1999 and 2000, the majority of the Politburo rejected the final draft of the bilateral trade agreement (BTA) with the United States. 


\section{Lack of Party's consensus on political priority for economic reform}

Another reason for the delay in signing the BTA was related to the diverging political priorities in 1999. Indeed, the Party Central Committee convened many Plenums in 1999, the Sixth (second round) from January 25 to February 2, the Seventh from August 9-16, and the Eighth from November 4-11. However, these Plenums did not focus on the economic reforms, including the BTA with the U.S. Instead, the CPV agenda focused on the need for political stability and internal reshuffling of the Party. It was clear that, as the BTA was ready for signing, party unity and political stability, rather than economic issues, were the main concerns of the three plenums. The CPV deferred the adoption of a comprehensive economic reform package that was being urged on it by the progressive group of the party and international donors.

Indeed, the Sixth Plenum focused on a number of fundamental and urgent issues important to the strength and role of the Party as a controlling governing institution. The resolution of this plenum showed that the main concern of the CPV was to maintain internal stability and party unity in the face of a regional crisis and the forces of globalization. The stated intention was to ensure the creation of a politically, ideologically, and organizationally strong Party in parallel with the requirements of social stability. The survival of the CPV as a ruling party required that it rid itself of internal disunity and close ranks against external challenges.

Reforming the Party, rather than economic or political liberalization, became a number one priority at the Plenum. Speaking to the Plenum, General Secretary Lê Khả Phiêu said that the CPV was plagued by several problems, including abuse of power, corruption, illegal enrichment, and internal disunity. He noted, "Some of these 
phenomena have serious consequences... and created conditions for hostile forces to sabotage our party, our regime." (Nguyen H. M., 2000). In response, the plenum adopted a resolution to launch a two-year intensive campaign of criticism and selfcriticism between May 1999 and May 2001 with the aim of improving the "revolutionary ethics [of party members] and fighting individualism" (Nguyen H. M., 2000).

At the Seventh Plenum (August 1999), the main concern of the CPV was over the issues related to the organization and apparatus of the political system, wages and social allowances funded by the state budget, and preparations for the forthcoming Ninth National Party Congress. With salaries not having been revised for many years, the plenum focused on the need to increase public service salaries and allowances. Again, it suggested that internal political matters, rather than economic reform to cope with Vietnam's decreasing economic growth, were to be the main preoccupation of the Party at this point of time.

In short, even though a comprehensive trade agreement with the U.S. was ready to be signed to complete the normalization process between the two countries, to open up the Vietnamese economy and further integrate it into the global economy in response to the Asian Financial Crisis, the BTA was not the main priority of the Party in 1999. Until the Eighth Plenum of the Party Central Committee of the Eighth National Party Congress of the CPV met in Hanoi from November 4-11 to discuss the pressing problems facing the country, no new major economic reforms had been undertaken (Nguyen H. M., 2000). The CPV continued to focus on political issues instead of pushing the economic reforms, including the BTA with U.S. As a result, the 
anticipated signing of the trade deal with the U.S. was postponed in the last minutes, which surprised many from both the Vietnamese and U.S. sides.

By 2000, Vietnam had felt fierce and devastating consequences of the Asian Financial Crisis more clearly. Within the leadership segment of the Party, there was a change in the balance of power among the conservatives and reformers. The Secretary General, a conservative leader, was faced with many political problems and losing his personal leadership legitimacy (Abuza, 2001). He gradually lost the leadership role to the reformer groups who advocated for comprehensive economic changes. In addition, China had signed the same BTA with the U.S. in November 1999. All of these factors led to the dominance of the reformer group within the Party, which in turn allowed for the signing of the BTA with U.S in July 2000. However, it should be noted that it took one more year for the leaders to wholeheartedly accept the BTA marked by the Resolution on International Economic Integration in November 2001 directing the National Assembly to officially ratify the BTA.

\section{Conclusion on the relevance of the proposed policy change model to the}

\section{case}

The case of the Bilateral Trade Agreement with the United States has proved the accuracy and explanatory power of the major policy change model proposed in Chapter III. The Asian Financial Crisis in 1997 put a great deal of pressures on the Vietnamese Party and government for comprehensive reforms, including the BTA with the US. Under the stressors, the Vietnamese Communist Party and government had already committed themselves to opening up its economy, and integrating deeper into the regional and global economic system. With the strong leadership predisposition to reform, Vietnam advanced the negotiation process with the U.S. 
sides on the BTA from 1997. During the three years from 1997 to 1999, there were changes in the policy images of the policy elites over the benefits and risks of the BTA and the technical issues under the BTA were resolved and agreed upon by the middle of 1999. However, at the time the BTA was ready to be signed, the highest leadership organ - the Politburo of the CPV decided to delay the BTA.

This delay can be well explained by the lack of consensus among the top leaders of the Party in terms of the pace and extent of economic reforms. While the reformers wanted to accelerate economic reforms to cope with the slowing economy, the conservatives were strongly concerned about the political risks and problems arising from rapid changes. At that time, the Party Secretary General was unable to take the leadership role in reaching consensus among the top leaders who were divided over the pace of change. Also, in 1999, there is extensive evidence that the top priorities of the CPV were political stability and internal unity instead of economic reform. As a result, even though the BTA was considered technically feasibility, it was not signed in 1999. This policy phenomenon supported the proposition No. 4 of the proposed policy model in Chapter III that political judgment can dominate technical feasibility of a major policy change initiative in Vietnam.

It took almost one year of additional internal debates and deliberation within the leadership of the Party to ensure the signing of the BTA. By the middle of 2000, the reformers managed to persuade the conservatives and gained the leadership position within the Politburo. As the result, the BTA was finally signed in July 2000. However, the National Assembly did not officially pass the BTA until one day after the CPV issued a special Resolution on International Economic Integration on November 27, 2001. Earlier, in April 2001, the new Party Secretary General was 
elected, which helped the reformers reach the final consensus on trade liberalization and the CPV stood firm on its will to push for Đổi Mới II, especially after the signing of the BTA with the U.S. 


\section{Chapter VII: A Case of Lacking Significant Policy Image Change in State-owned Enterprise Management in Vietnam}

In recent years, few issues have evoked more passionate debate in Vietnam than the issue of state ownership in the market economy and the recent scandals related to some state general corporations and economic groups. More than 20 years since Vietnam's Renovation Program (Đổi Mới) for a transition to a market-oriented economy, the outsiders would be surprised that by 2009 , the share of state-owned enterprises (SOEs) in capital, fixed assets, bank credit, and employment in the enterprise sector was still as high as $39,45,27$, and 19 percent, respectively (The Vietnam Consultative Group Meeting, 2011). In the highest official documents and statements by Party and government leaders, state-owned enterprises remained the cornerstone of the entire economy. Despite negative economic performance on the part of most of the state economic groups (SEGs) and general corporations (SGOs), the Party and government has stood firm on its will to retain a strong state economic sector as the tools for macro-economic monitoring and for assuring the social welfare system of the country. Over the past two decades, the government has conducted a variety of incremental changes and adjustments in its legal framework for the SOE sector, especially when the country integrated more fully into the world economy. However, no comprehensive reform in the state economic sector has been made when the General Party Secretary of CPV in his closing speech at the $6^{\text {th }}$ Plenum of the Party Central Committee under the XI National Party Congress, on October 15, 2012, announced that state-owned economic sector would remain its central role in the economy (Nguyen T. P., 2012). Thus, people both inside and outside the country have 
posed several important questions: Have the Party and government leaders felt the stressors to reform the state economic sector? If so, have they committed to reform? If the answer to both questions is yes, what has prohibited Vietnam from bringing their reforms to fruition?

This case study is structured to shed light on answer of these questions. The first section reviews the role and economic performance of the state-owned enterprise sector in Vietnam, which will provide the policy context for this case study and for my descriptive analysis in the following sections. I will include a timeline of policy changes in state management over state-owned enterprises that have occurred over the past two decades. In the second section of this chapter, I will use the proposed major policy change model presented in Chapter III of this dissertation to explain the policy process and outcomes with respect to the state economic sector and its enterprises. Specifically, I intended to use the change factors and the causal flow of change identified in the model including stressors, leadership predisposition to reform, policy image to explain the lack of radical policy changes and innovation in the state economic sector. Finally, some conclusions will be drawn to evaluate the explanatory capacity of policy model proposed for Vietnam in this case.

The method I am using for this case study is secondary document review. In order to identify the performance data and information related to state-owned enterprises, I will rely on a critical study that is summarized in the recent Vietnam Development Report 2012: Market Economy for a Middle-Income Vietnam, presented at the Vietnam Consultative Group Meeting in December 06, 2011, sponsored by World Bank (hereafter cited as The Vietnam Consultative Group Meeting, 2011). I 
will supplement reliance on this report with information from Party and government's official documents, empirical researches, and policy statements of policy elites.

\section{Introduction to the state economic sector in Vietnam}

Over the past two decades since Đổi Mới in 1986, the government of Vietnam has conducted a number of changes in the relationship between the government and SOEs, especially in replacing central planning powers with substantial enterprise autonomy. Compared to the period before Đổi Mới, SOEs have much higher authority to set most of the prices based on the marketplace, select appropriate production inputs, determine their own investment strategies, manage their human resources and assets, and apply appropriate institutional organizations (The Vietnam Consultative Group Meeting, 2011). These policy changes were intended to help state-owned enterprises catch up with the rules of the market economy and to increase the efficiency.

Along with providing more autonomy to state firms, during the 1990s and the past decade, Vietnam equitized small and medium-size SOEs, and consolidated others into larger entities, called General Corporations. Between 1989 and 1992, thousands of small, loss-making and inefficient SOEs were closed or merged, reducing their numbers from 12,084 to some 6000 (Dixon, 2003). The number of SOEs did not change much between 1992 and 1999 which was a period for the government to consolidate the state economic sector by ending the mechanism of direct subsidies, revising the incentive structures for workers and managers and increasing the level of autonomy (The Vietnam Consultative Group Meeting, 2011). From 2000, the process of equitizing state-owned enterprises was accelerated again, especially in two years before Vietnam accession to WTO in 2006. Notably, among the 3.388 equitized SOEs 
in the period 2001-2011, 58\% were local firms, 32\% were managed by line ministries and only $10 \%$ were general state corporations and state economic groups under the control of the central government (Vu A. T., 2011). After 20 years of equitization, only $15 \%$ of state capital in SOE sector was transferred to private holders, which was a very modest number.

From 2006 to 2010, the trend was reversed compared to the previous periods, especially after Vietnam joined the WTO and after the issuance of the Government Decree No. 101 on Pilot Establishment of State Economic Group in November 2009. This reversal can be explained by the desire of Vietnam leaders to emulate the experiences of Japan's Keiretsus and the Republic of Korea's Chaebols (Beresford, 2008). Indeed, in 2005, Vietnam accelerated the process of creating State Economic Groups (SEGs), which represent the loose alliances of a number of SOEs with similar business interests prior to the country's accession to WTO to ensure the international competitiveness of the domestic economy. By the end of 2010, according to an official report, there were 3,364 SOEs in which the government had a controlling stake by owning 51 percent or more of the charter capital (GSO, cited by The Vietnam Consultative Group Meeting, 2011). Among those, some 1,300 SOEs were $100 \%$ state ownership.

Generally, the importance of the state sector in the overall economy has steadily declined as the domestic private and foreign sectors have rapidly grown over the last two decades. In 2000, SOEs accounted for nearly 68 percent of capital, 55 percent of fixed assets (such as land), 45 percent of bank credit, and 59 percent of the jobs in the enterprise sector (The Vietnam Consultative Group Meeting, 2011). Since then, these numbers have steadily fallen, though at different speeds. The steepest 
decline has been in the employment share of SOEs, from 59 percent in 2000 to 19 percent in 2009, as the labor-intensive SOEs have been equitized and the domestic private and foreign enterprises have rapidly expanded their labor force. Except for a few subsectors such as construction and insurance, the number of enterprises under state ownership is fairly small relative to the number of firms operating in the nonstate and foreign-owned sectors (The Vietnam Consultative Group Meeting, 2011).

However, the state sector still has a sizable presence in the economy. As has been mentioned earlier, by 2009, the share of SOEs in capital, fixed assets, bank credit, and the employment in the enterprise sector were still 39, 45, 27, and 19 percent, respectively. Notwithstanding relatively declined proportion of state ownership within the economy, the state not only controls all the critical business sectors, but also has considerable presence in various commercial activities. The stateowned enterprises enjoy near-monopoly status in the production of key goods and services, including fertilizer (99 percent), coal (97 percent), electricity and gas (94 percent), telecommunications (91 percent), water supply (90 percent), and insurance (88 percent) (The Vietnam Consultative Group Meeting, 2011). The state justifies a large state presence in these business areas by considering them as basis for the economy and seems reluctant to allow non-public sectors to invest in these areas. More surprisingly, the state has also maintained its presence in various consumer goods such as cement (51 percent), beer (41 percent), refined sugar ( 37 percent), textiles (21 percent), and chemicals (21 percent). Until 2011, among the 100\% SOEs, a third of the total enterprises $(417$ out of 1,300$)$ operated in the areas of commerce, service, and tourist which do not necessary need the participation of the state $(\mathrm{Vu} \mathrm{A}$. T., 2011). 
Especially in the banking section, by 2010, among the largest banks, the state controls $100 \%$ capital of two banks and from $80-92 \%$ of other three (The Vietnam Consultative Group Meeting, 2011). The number of joint-stock banks (JSBs) with state capital progressively increased to 22 by 2010 compared to five in 2005 , implying that nearly 60 percent of JSBs had some charter capital from the state. The amount of state capital in the JSBs has steadily increased from nearly VND 1 trillion in 2005 to VND 15 trillion in 2010. Thus, both in terms of the number of banks and the absolute amount of charter capital, the state's presence in the banking sector has increased. Notably, the large majority of state ownership in the banking sector comes through the SOEs, which hold charter capital in as many as 19 JSBs (The Vietnam Consultative Group Meeting, 2011).

From the above review, we can see that even though the relative position of the SOEs within the national economy of Vietnam has declined, the size and influence of this sector is still very large. In order to maintain a strong state economic sector, the government has provided the SOEs with preferential access to banking credit,

procurement contracts, and research and development, etc., compared to their peers in the private sector. For example, over the past years, SOEs have received averagely about $70 \%$ of the total ODA of Vietnam. Now, the question turns to the economic performance of this economic sector.

\section{Inefficiency and low productivity}

According to the report of the Vietnam Consultative Group Meeting (2011), the SOEs use several times more capital to produce one unit of output than the industry average. In 2000, the average ratio of turnover to capital in SOEs, which is a proxy for the productivity of capital, was 1.6 compared to 8.8 for the enterprise sector 
as a whole. This implies that on average SOEs required nearly five times units of capital to produce one unit of output (turnover) than the industry average level. This is not entirely unexpected since SOEs specialized in the production of more capitalintensive products at that time. What is quite alarming, however, is that by 2009 the average ratio of turnover to capital for the SOEs fell to 1.1 while it increased to 21.0 for the industry. Thus, while the enterprise sector, as a whole was getting better at using capital more economically, the SOEs were becoming even more inefficient.

The growth of labor productivity in SOEs has not kept pace with the rest of the industry too. Since SOEs have higher capital intensity than the rest of the industry, and since this intensity has rapidly increased in recent years, one would expect SOEs to experience higher and rising labor productivity relative to the rest of the enterprise sector. The evidence, however, shows the opposite. As indicated in the report of the Vietnam Consultative Group Meeting (2011), between 2000 and 2008, the turnoverto-employee ratio in SOEs, which represents for the productivity of labor, increased from 0.6 to 1.7 . During the same period, the turnover-to-employee ratio for the overall enterprise sector increased from 2.7 to 16.3 , indicating that labor productivity gap between SOEs and the rest of the enterprise sector widened from 1:4 in 2000 to 1:10 in 2008 .

SOEs are also less efficient in their use of fixed assets such as land and machinery. Research shows that the turnover-to-fixed asset ratio, a proxy for the productivity of land and machinery, fell for SOEs between 2000 and 2008, while it remained unchanged for the whole enterprise sector during the same period (The Vietnam Consultative Group Meeting, 2011). Moreover, the average net loss of stateowned enterprises is 12 times higher than those of non-state sector enterprises. 
According a report from the Ministry of Finance (Vneconomy, 2012), the total accumulative loss of the state corporations and economic groups by the end of 2011 was 26,100 billion VND (approximately 1.25 billion USD). Among the worst performance companies, the General Electricity Corporation (EVN) lost 12,313 billion VND (around 600 million USD); Vietnam Shipbuilding Industry Group (Vinashin) lost 5,000 billion VND (around 200 million USD) in 2010; the General Telecommunication Corporation lost 1,026 billion VND (around 50 million USD) in 2009. Thus, the SOEs have not only used production factors inefficiently, but their level of inefficiency has greatly accelerated in recent years.

\section{In serious debt}

Along with being operationally less efficient, SOEs are also found to be financially less prudent. The SOEs have the highest debt-to-asset ratio among the three groups and have been exposed to a large proportion of debt within the entire economy. Between 2007 and 2009, the debt-to-equity ratio of SOEs averaged 307 percent relative to 183 percent for non-state domestic firms and 145 percent for foreign firms (The Vietnam Consultative Group Meeting, 2011). Especially, the debtto-equity ratio of the state economic groups increased to 3.2 times from the level of 2.6 in 2005 before they were upgraded from the general state corporations.

By September 2011, the total debt amount of state-owned economic enterprises was 415,347 billion VND (around 20 billion USD), occupying up to $16.9 \%$ of the total debt of the banking system (Vneconomy, 2012). According the Proposal of Restructuring State-owned Enterprises documented by the Ministry of Finance in late 2011, only 12 state economic groups and general corporations have a debt amount of 218.738 billion VND (around 10 billion USD), accounting for $8.76 \%$ 
of the total debt of the economy and $52.66 \%$ of the total debt of the state economic sector (Vneconomy, 2012). Also, according to this document, 30 out of 85 state economic groups and general corporations have a debt amount of more than three times and seven of ten times higher than their total equity. More seriously, SOEs in general and the state economic groups and state general corporations in particular are responsible for about $70 \%$ and $53 \%$, of the total bad loans of the whole banking system, respectively. (Dinh M. T., 2012).

\section{Non-core investment}

Another problem with the state-owned enterprises is their large scale investments in non-core business activities while their core businesses witnessed huge losses. Instead of focusing on their core missions and on promoting their international competitiveness (as expected by the government), many state-owned enterprises used the preferable loans from the government and state banks to invest in stock markets, real estates and joint-stock banks to gain short-term profit. For example, by the end of 2010, according to a report of the General Accounting Office, the General Electricity Corporation of Vietnam had invested more than 4,551 billion VND (around 220 million USD), accounted to $13 \%$ of charter capital in none-core activities; the State Economic Group of Vinalines had invested 672 billion VND, accounted to $10.37 \%$ of charter capital; and the Vietnam National Coal - Mineral Industries Group State Economic Group had invested 1.828 billion VND, accounted to $12.1 \%$ of charter capital (Electronic Newspaper of Vietnam State Bank, 2012).

All of the negative performance of the state economic sector came to a climax when the Vietnam Shipbuilding Industry Group (Vinashin), one of the largest state economic groups (SEGs), had to announce bankruptcy. In the middle of 2010, more 
than 5,000 Vinashin workers lost their jobs and the company failed to pay US\$12 million in salaries and social insurance. The total debt of Vinashin was reported to be US $\$ 4.4$ billion in July 2010 -more than 300 percent of its annual sales and as much as 10 times its equity base (The Vietnam Consultative Group Meeting, 2011). According to a report by the General Inspection Office, which was submitted to the National Assembly in July 2010, Vinashin's problems can be traced to the following factors: (a) violating regulations on project formulation, approval, and bidding, and incurring huge debt; (b) falsifying financial reports; (c) establishing as many as 200 subsidiaries and expanding outside its core business operations (such as securities, real estate, and tourism); and (d) the chairman committing serious violations and infringing regulations on the mobilization, management, and use of state capital (cited in the Vietnam Consultative Group Meeting, 2011). The day after the General Inspection Office's report was submitted to the National Assembly; the chairman of Vinashin was suspended and detained on mismanagement charges. Several other senior Vinashin officials were also subsequently arrested. A steering committee, chaired by a deputy prime minister, was set up to restructure Vinashin.

The Vinashin scandal is not the only case. In 2012, another state economic group, Vinalines, was also under investigation and the Director General of the Vinalines was convicted and arrested for the mismanagement and abuse of power. Some prominent businessmen and leaders of the biggest domestic banks in Vietnam were also arrested and investigated in 2012. The weaknesses and problems of many other state-owned enterprises were gradually revealed, especially after the Vinashin scandals triggered investigations over the whole state economic system. These incidents spurred a nationwide debate about the role of the state involvement and 
ownership, including the role and efficiency of the SGCs and SEGs in Vietnam's economy. Key elements that led to the negative performance of the SOEs have been repeatedly mentioned in state documents including weak corporate governance (including ineffective internal controls, limited transparency and disclosure, no independent external audits), lack of effective oversight and monitoring, and the excessive power of senior management to operate and expand the business without effective transparency and accountability regulations.

At all of the political forums within the Party Central Committee, the National Assembly, the central government and its ministries, participants have joined a growing consensus that SOE restructuring is now required. Opinion is divided, however, about the nature and extent of restructuring. There are some who believe that only minor restructuring (such as trimming capital expenditure) is enough to restore the health of SOEs and they can then return to playing their leading role in the economy. There are others who think that a more radical restructuring, including equitization of SEGs and transferring the role and function of SOEs to the marketplace, is in the country's long-term interest. To this view, if the problems that led to the fall of Vinashin reflect the generic issues affecting the state sector, then SOEs do face serious challenges that can be addressed only through a comprehensive reform program.

An accumulated set of SOE scandals in recent time have confronted the Vietnamese Party and government with essential the problems of SOEs and the urgent need for restructuring this sector. In fact, a variety of legal documents and directives have been promulgated with the hope of increasing the efficiency and performance of the SOEs over the past two decades especially after the recent scandals related to poor 
performance of the state economic groups. However, the policy changes have been

incremental and have focused on equitization of inefficiency small firms and on

internal enterprise management improvement instead of innovative changes in the

policy image on the roles of SOEs and the nature of state ownership. Following are

some critical documents promulgated by the Party and government reflecting the

regime's views over the state economic sector and state management in this sector.

Table 11: Resolutions, decrees, and directives of the CVP and government regulating the state economic sector in Vietnam

\begin{tabular}{|c|c|c|c|}
\hline No & Name and Date & Main contents & Policy implication \\
\hline 1 & $\begin{array}{l}\text { June 1991: The Political } \\
\text { Report at the VII } \\
\text { National Party Congress } \\
\text { and the Resolution on } \\
\text { "Development Strategy } \\
\text { of the Nation during the } \\
\text { Transitional Period } \\
\text { toward Socialism" }\end{array}$ & $\begin{array}{l}\text { These two documents started to } \\
\text { recognize the rights and roles of } \\
\text { private enterprises while reaffirming } \\
\text { the pivotal role of the state } \\
\text { economic sector. }\end{array}$ & $\begin{array}{l}\text { Raised the constraints and } \\
\text { limitations of the state } \\
\text { economic sector and the need } \\
\text { to consolidate the role and } \\
\text { improve the performance of } \\
\text { this sector. }\end{array}$ \\
\hline 2 & $\begin{array}{l}\text { March 1994: Prime } \\
\text { Minister's Decision No } \\
\text { 91/TTG on the Pilot } \\
\text { Establishment of State } \\
\text { Business Groups and } \\
\text { Decision No. 90/TTG on } \\
\text { the Restructuring of } \\
\text { State-owned Enterprises }\end{array}$ & $\begin{array}{l}\text { The main goal of these Decisions } \\
\text { was to create favorable conditions } \\
\text { for the accumulation and } \\
\text { concentration of resources and } \\
\text { increase the competitiveness of key } \\
\text { state-owned enterprises. }\end{array}$ & $\begin{array}{l}\text { Allowed state economic groups } \\
\text { to do business in different } \\
\text { areas with a requirement to } \\
\text { focus on their core business. }\end{array}$ \\
\hline 3 & $\begin{array}{l}\text { April 1995: Law on State } \\
\text { Enterprises }\end{array}$ & $\begin{array}{l}\text { The Law distinguishes between } \\
\text { state enterprises that operate for } \\
\text { profit and those that have wider } \\
\text { social obligations such as public } \\
\text { utilities and national defense. }\end{array}$ & $\begin{array}{l}\text { This is the first Law which is } \\
\text { aimed at providing a regulatory } \\
\text { framework for the Party and } \\
\text { government to direct, manage, } \\
\text { and control the SOEs. }\end{array}$ \\
\hline 4 & $\begin{array}{l}\text { June 1996: VIII National } \\
\text { Party Congress: the } \\
\text { Political Report and } \\
\text { Five-year Socio- } \\
\text { economic Strategic Plan }\end{array}$ & $\begin{array}{l}\text { The State economic sector was } \\
\text { designated to take the pivotal } \\
\text { position in the economy, especially } \\
\text { involving industry, infrastructure } \\
\text { and finance. }\end{array}$ & $\begin{array}{l}\text { Continued to raise the need for } \\
\text { consolidating the roles of the } \\
\text { state economic sector. No } \\
\text { major concerns were expressed } \\
\text { about the performance of the } \\
\text { SOE sector. }\end{array}$ \\
\hline 5 & $\begin{array}{l}\text { August 2001: the } \\
\text { Resolution of the Third } \\
\text { Plenum of the Central } \\
\text { Party Committee of the } \\
\text { IX National Party } \\
\text { Congress regarding } \\
\text { reorganization, reform, } \\
\text { and development of the } \\
\text { SOEs. }\end{array}$ & $\begin{array}{l}\text { The Resolution established the } \\
\text { development strategy and principles } \\
\text { for state management of SOE } \\
\text { sector. }\end{array}$ & $\begin{array}{l}\text { This is first document of the } \\
\text { CPV specific to SOEs. It } \\
\text { recognized the weaknesses of } \\
\text { the sector and called for } \\
\text { renovation in state } \\
\text { management and restructuring, } \\
\text { especially after Vietnam signed } \\
\text { the BTA with the U.S. in July, } \\
2000\end{array}$ \\
\hline 6 & $\begin{array}{l}\text { June 2003: the } \\
\text { Resolutions No. 28- }\end{array}$ & $\begin{array}{l}\text { The Party wanted to reshuffle and } \\
\text { restructuring the state enterprises in }\end{array}$ & $\begin{array}{l}\text { To implement this Resolution, } \\
\text { in 2004, the Government }\end{array}$ \\
\hline
\end{tabular}




\begin{tabular}{|c|c|c|c|}
\hline & $\begin{array}{l}\text { NQ/TW of the Politburo } \\
\text { on reshuffling, reforming } \\
\text { and developing state } \\
\text { farms and forestry firms. }\end{array}$ & agriculture sector. & $\begin{array}{l}\text { promulgated Decree No. } 170 \\
\text { and } 200 \text { stressing the need to } \\
\text { increase efficiency of state } \\
\text { farms and restructuring this } \\
\text { sector by equitization. }\end{array}$ \\
\hline No & Name and Date & Main contents & Policy implication \\
\hline 7 & $\begin{array}{l}\text { December 2003: Revised } \\
\text { Law on State Enterprises }\end{array}$ & $\begin{array}{l}\text { This Law revises the Law on State } \\
\text { Enterprises in } 1995 .\end{array}$ & $\begin{array}{l}\text { The Law is to realize Party's } \\
\text { strategies and resolutions } \\
\text { especially the Resolution of the } \\
\text { Third Plenum of the Central } \\
\text { Party Committee of the IX } \\
\text { National Party Congress in } \\
2001\end{array}$ \\
\hline 8 & $\begin{array}{l}\text { November 2009: } \\
\text { Government Decree No. } \\
101 \text { on Pilot } \\
\text { Establishment of State } \\
\text { Economic Group }\end{array}$ & $\begin{array}{l}\text { The main goal is to concentrate the } \\
\text { investments and mobilize resources } \\
\text { to establish large-scale state } \\
\text { economic groups in key economic } \\
\text { areas in order to increase } \\
\text { competitiveness of the domestic } \\
\text { economy and to help monitor the } \\
\text { industrialization process. It allows } \\
\text { the establishment of } \\
\text { State Economic Groups (SEGs), } \\
\text { which are a loose alliance of several } \\
\text { SOEs with similar business } \\
\text { interests. }\end{array}$ & $\begin{array}{l}\text { This Decree intended to realize } \\
\text { the strategy in the Party's } \\
\text { Resolution in } 2001 \text { on } \\
\text { restructuring the state } \\
\text { economic sector. In response to } \\
\text { trade liberalization and } \\
\text { international economic } \\
\text { integration (WTO), from 2005- } \\
\text { 2010, Vietnam established the } \\
\text { following pilot SEGs: Vietnam } \\
\text { Post and Telecommunications, } \\
\text { Vietnam National Coal- } \\
\text { Mineral Industries, and } \\
\text { Vietnam National Textile and } \\
\text { Garment in 2005; Petro } \\
\text { Vietnam, Vietnam Electricity, } \\
\text { Vietnam Shipbuilding } \\
\text { Industry, } \\
\text { Vietnam Rubber in 2006; } \\
\text { Baoviet Insurance in 2007; } \\
\text { Vietnam National Chemical } \\
\text { Industrial Group, Industrial } \\
\text { Construction Group in 2009; } \\
\text { and Vietnam Housing and } \\
\text { Urban Development in 2010. }\end{array}$ \\
\hline 9 & $\begin{array}{l}\text { November 2009: } \\
\text { National Assembly's } \\
\text { Resolution No. } \\
\text { 42/2009/QH12 on } \\
\text { Increasing the Law } \\
\text { Enforcement and Policy } \\
\text { Implementation in } \\
\text { Management, Resource } \\
\text { Usage, and Asset } \\
\text { Management of SEGs } \\
\text { and SGCs }\end{array}$ & $\begin{array}{l}\text { This Resolution strongly emphasize } \\
\text { weaknesses and problems of SOEs a } \\
\text { called for more effective state } \\
\text { management and restructuring. }\end{array}$ & $\begin{array}{l}\text { thais Resolution was issued } \\
\text { hdfter some independent } \\
\text { investigations revealed the bad } \\
\text { performance of SOEs. }\end{array}$ \\
\hline 10 & $\begin{array}{l}\text { July 2010: Special } \\
\text { Conclusion No. } 78 \text { - } \\
\text { KL/TW of the Politburo } \\
\text { on Reinforcing the } \\
\text { Implementation of the } \\
\text { Resolution of the Third } \\
\text { Plenum at the IX Party } \\
\text { Congress and the }\end{array}$ & $\begin{array}{l}\text { Although the Conclusion admitted } \\
\text { problems and difficulties of SOEs } \\
\text { and the need for reforming and } \\
\text { restructuring the state economic } \\
\text { sector, it continued to confirm: } \\
\text { "Party's principles on the key role } \\
\text { of SOEs in the national economy } \\
\text { are proved to be correct". }\end{array}$ & $\begin{array}{l}\text { The Conclusion attributed the } \\
\text { bad performance of the leaders } \\
\text { and the limitation of internal } \\
\text { management to the constraints } \\
\text { and problems of SOEs instead } \\
\text { of the ownership nature of } \\
\text { SOEs. It also encouraged the } \\
\text { development of the State }\end{array}$ \\
\hline
\end{tabular}




\begin{tabular}{|c|c|c|c|}
\hline & $\begin{array}{l}\text { Resolution of the } X \\
\text { Congress regarding } \\
\text { reorganization, reform, } \\
\text { and development of the } \\
\text { SOEs. }\end{array}$ & & $\begin{array}{l}\text { Capital and Investment } \\
\text { Corporation to facilitate } \\
\text { restructuring SOEs and } \\
\text { consolidate the role of the state } \\
\text { in key economic areas. }\end{array}$ \\
\hline No & Name and Date & Main contents & Policy implication \\
\hline 11 & $\begin{array}{l}\text { January 2011: The } \\
\text { Socio-economic } \\
\text { Development Plan 2011- } \\
2020\end{array}$ & $\begin{array}{l}\text { Continued to affirm that "state } \\
\text { economic sector play a central role } \\
\text { as the important material force for } \\
\text { the state to direct and monitor the } \\
\text { entire economy, contributing to the } \\
\text { macroeconomic stability". }\end{array}$ & $\begin{array}{l}\text { This is the key five-year } \\
\text { development plan of the Party } \\
\text { that influences all policies of } \\
\text { the Government in the coming } \\
\text { years. Unless, there is a special } \\
\text { document of the Party to } \\
\text { change the status quo, no } \\
\text { radical would be made. }\end{array}$ \\
\hline 12 & $\begin{array}{l}\text { February 2011: } \\
\text { Government Resolution } \\
\text { No. 11/NQ-CP on } \\
\text { Retaining Inflation Rate, } \\
\text { Stabilizing Macro } \\
\text { Economy, and Ensuring } \\
\text { Social Welfare. }\end{array}$ & $\begin{array}{l}\text { The Resolution emphasized the } \\
\text { importance of providing solutions to } \\
\text { high inflation rate from } 2008 \text { to } \\
2011 \text {, including measures of } \\
\text { reducing bank credit, public } \\
\text { expenditure, and investment in real } \\
\text { estate. }\end{array}$ & $\begin{array}{l}\text { This Resolution demonstrated } \\
\text { strong concerns of the } \\
\text { Government regarding the } \\
\text { macroeconomic performance } \\
\text { of the entire economy. Among } \\
\text { the solutions, it mentioned the } \\
\text { need to cut back unnecessary } \\
\text { investments of SOEs and to } \\
\text { restructure low performing } \\
\text { SOEs to save the money. }\end{array}$ \\
\hline 13 & $\begin{array}{l}\text { March 2011: Prime } \\
\text { Minister's Decision on } \\
\text { Standards to Classify the } \\
\text { SOEs }\end{array}$ & $\begin{array}{l}\text { This Decision classified different } \\
\text { types of SOEs, setting the stage for } \\
\text { restructuring the state economic } \\
\text { sector by equitization }\end{array}$ & $\begin{array}{l}\text { In many previous documents, } \\
\text { the Vietnamese Party and } \\
\text { Government emphasized the } \\
\text { need to classify SOEs into } \\
\text { different categories. According } \\
\text { its classification, the } \\
\text { Government would retain the } \\
\text { control over the important } \\
\text { economic areas and equitize } \\
\text { SOEs in not-so-important } \\
\text { economic areas. The Decision } \\
\text { differentiated SOEs by the } \\
\text { following functions: those } \\
\text { related to social welfare system } \\
\text { and those related to economic } \\
\text { monitoring. }\end{array}$ \\
\hline 14 & $\begin{array}{l}\text { March 2011: Conclusion } \\
\text { No. 2-KL/TW of the } \\
\text { Politburo on the Socio- } \\
\text { economic Situation in } \\
2011\end{array}$ & $\begin{array}{l}\text { Among the solutions for the socio- } \\
\text { economic development, the } \\
\text { Conclusion emphasized "enhancing } \\
\text { SOEs restructuring by equitization; } \\
\text { focusing on the core business areas } \\
\text { of SEGs; not encouraging } \\
\text { investment in non-core activities; } \\
\text { clarifying state ownership in SOEs; } \\
\text { promulgating more regulations to } \\
\text { identify the accountability of } \\
\text { individuals and organizations in } \\
\text { using state resources". }\end{array}$ & $\begin{array}{l}\text { This is another document } \\
\text { showing great stressors to the } \\
\text { regime due to the negative } \\
\text { economic indicators from } 2008 \\
\text { and the impacts of the world } \\
\text { financial crisis. }\end{array}$ \\
\hline 15 & $\begin{array}{l}\text { July 2011: Government } \\
\text { Decree No. 59/2011/NĐ- } \\
\text { CP on transforming } \\
100 \% \text { state-owned } \\
\text { enterprises into joint- }\end{array}$ & $\begin{array}{l}\text { The Decree guided the process and } \\
\text { procedures to transform not- } \\
\text { required } 100 \% \text { SOEs into joint- } \\
\text { stock companies with multiple types } \\
\text { of ownership in order to increase }\end{array}$ & $\begin{array}{l}\text { It should be noted that the } \\
\text { Government only wants to } \\
\text { equitize SOEs whose } \\
\text { businesses are not in the key } \\
\text { economic areas. }\end{array}$ \\
\hline
\end{tabular}




\begin{tabular}{|c|c|c|c|}
\hline & stock companies & $\begin{array}{l}\text { efficiency and performance of the } \\
\text { enterprises. }\end{array}$ & \\
\hline No & Name and Date & Main contents & Policy implication \\
\hline 16 & $\begin{array}{l}\text { December 2011: The } \\
\text { Ministry of Finance } \\
\text { organized a Conference } \\
\text { on "Restructuring the } \\
\text { Economy" chaired by the } \\
\text { Minister of Finance. }\end{array}$ & $\begin{array}{l}\text { At the Conference, the Minister of } \\
\text { Finance, Vuong Dinh Hue, } \\
\text { presented a keynote speech on } \\
\text { "Solutions for Restructuring SOEs, } \\
\text { with emphasis on State Economic } \\
\text { Groups and General Corporations". }\end{array}$ & $\begin{array}{l}\text { The Minister reaffirmed the } \\
\text { critical role of SOEs as the } \\
\text { macroeconomic monitoring } \\
\text { tools and to the primary agents } \\
\text { for ensuring the welfare of the } \\
\text { state. Moreover, restructuring } \\
\text { is not to curtail the role of } \\
\text { SOEs but to consolidate their } \\
\text { functions and missions as the } \\
\text { cornerstone of the socialist- } \\
\text { oriented economy. } \\
\text { Restructuring should include } \\
\text { both adjustments in the policy } \\
\text { framework and improvement } \\
\text { in internal management within } \\
\text { the individual enterprise. }\end{array}$ \\
\hline 17 & $\begin{array}{l}\text { July 2012: Prime } \\
\text { Minister's Resolution } \\
\text { No. 929/QD-TTg on } \\
\text { "Program on } \\
\text { Restructuring State- } \\
\text { owned Enterprises with } \\
\text { emphasis on State } \\
\text { Economic Groups and } \\
\text { General Corporation in } \\
\text { the period 2011-2015" }\end{array}$ & $\begin{array}{l}\text { The Resolution identifies areas in } \\
\text { which the government retains } \\
\text { different proportion of ownership: } \\
100 \% \text {, over } 75 \% \text {, from } 60-75 \% \text {, and } \\
\text { from } 50-65 \% \text {. SOEs operating in the } \\
\text { rest of economic areas will be } \\
\text { equitized. The Prime Minister also } \\
\text { urged completing the regulatory } \\
\text { framework in managing the SOEs. }\end{array}$ & $\begin{array}{l}\text { This is the most updated and } \\
\text { key document of the } \\
\text { Government that demonstrated } \\
\text { the key policy images and } \\
\text { political values of the Party } \\
\text { and Government related to the } \\
\text { role of state economic sector. } \\
\text { Yet, it reveals that the state still } \\
\text { wants to retain the control over } \\
\text { most of the important business } \\
\text { areas. }\end{array}$ \\
\hline 18 & $\begin{array}{l}\text { November 2012: } \\
\text { Government Decree } \\
\text { No.99/ND-CP on } \\
\text { Dividing and Delegating } \\
\text { Rights, Responsibilities, } \\
\text { and Missions of the State } \\
\text { Ownership in SOEs and } \\
\text { State Investments in } \\
\text { Enterprises }\end{array}$ & $\begin{array}{l}\text { The Decree is to clarify the roles } \\
\text { and responsibilities of different } \\
\text { public authorities in the state } \\
\text { management over the SOE sector } \\
\text { and to delegate some power from } \\
\text { the central government of the line } \\
\text { minstries and provincial authorities }\end{array}$ & $\begin{array}{l}\text { The Decree continues to } \\
\text { confirm the will of the state to } \\
\text { invest in key business areas of } \\
\text { the economy in order for the } \\
\text { state economic sector to } \\
\text { maintain the leading role and } \\
\text { for the state to monitor the } \\
\text { economy. }\end{array}$ \\
\hline
\end{tabular}

\section{Case analysis: explaining the lack of radical change in state-owned}

\section{enterprise management policy of Vietnam}

This section will take a deeper look at the policy process in the state economic

sector over the past decades and explain the final policy outcomes produced recently

in this sector. I am using the policy factors and arguments embedded in my major

policy change model in Chapter III to guide the policy analysis. Specifically, I will

employ the concepts of stressor, leadership predisposition, policy image to elucidate 
the policy process and outcomes in the policy areas of Vietnam. The main goal is to explain why radical change has not been made even after the recent scandals and mounting evidence of bad performance of the SOEs, especially the state general corporations and the state economic groups. My argument is that the Vietnamese Communist Party and government have not changed their policy image in terms of the central role of the state economic sector within the national economy. This policy image assumed that there was no conflict between a large and dominated state economic sector and the operation and development of a market-oriented economy in Vietnam. As the results, over the past years, although Vietnam regime has felt the stressors and expressed the predisposition to reform the state economic sector, only incremental policy changes have been made instead of radical and innovative reforms.

\section{Increasing stressors for reforms in state economic sector}

In a span of five years, between 2003 and 2008, Vietnam's GDP more than doubled from US $\$ 40$ billion to US $\$ 90$ billion, and its exports more than tripled from US\$20 billion to US\$63 billion (The Vietnam Consultative Group Meeting, 2011). During this time, Vietnam also became a member of the WTO, which triggered an unprecedented inflow of foreign direct investment; mounting to 72 registered billion USD in 2007. Domestically, this period coincided with the establishment of state economic groups (SEGs), a loose alliance of SOEs with similar business interests, which were expected as the strategy for Vietnam to cope with increasing international competitions when Vietnam accelerated it international economic integration. This period also saw booming total social investments, a thriving stock market, escalating real estate prices and rising prosperity throughout all sectors of the economy. It is, therefore, easy to overlook the fact that this period also coincided with declining 
contribution of productivity to growth, increased macroeconomic instability, fragmented development and the inability of public institutions to keep pace with a rapidly globalizing economy (The Vietnam Consultative Group Meeting, 2011).

Indeed, over the period from 2008 to 2011 , Vietnam had one of the highest inflation rates in Asia, averaging nearly 16 percent a year. Along with high inflation, Vietnam was coping with persistent pressure on its currency, falling levels of foreign exchange reserves, an underperforming stock market, and high domestic capital flight. Vietnam was an exception to the broader trend of the rest of the emerging markets in Asia with appreciating currencies, rising foreign exchange reserves, and increasing capital inflow (National Assembly of Vietnam, 2012). Affected by the World Economic Crisis, since 2008, Vietnam's economic growth has continuously slowed down. The average GDP growth of the period 2006-2010 was only $7.0 \%$ compared to the target of 7.5-8.0\% (National Assembly of Vietnam, 2012). The growth rate declined under 6\% in 2009 and 2011, and 5.2\% in 2012 - the lowest level since 2000.

The serious slowing of the entire economy and the poor economic performance of the state economic sector over the past few years have led to a macroeconomic report in June 2012: From economic instability to the restructuring path, produced by the Economic Committee of the National Assembly with the support of the International Economic Policy Consultative Group. The report strongly emphasized the low quality of the economic growth of Vietnam. Specifically, from 1991-1995, with a total social investment/GDP rate of $28.2 \%$, the economy reached an average annual growth rate of $8.2 \%$ while from the 2006-2010, with the rate of $42.7 \%$, the average growth was just $6.9 \%$; the numbers for 2011 were $34.6 \%$ and $5.9 \%$. In the period from 1990-2000, the contribution of capital to GDP was $34 \%$ 
while in the proceeding ten years; this rate was 53\%, reaching the highest level in the Asian region. The contribution of the total factor productivity (TFP) to the economic growth in the period from 2000-2008 was only $26 \%$ (much lower than China, India and other Southeast Asian countries) compared to 44\% of the period 1990-2000. In addition, Vietnam's competitiveness been threatened because power generation has not kept pace with demand, logistical costs and real estate prices have climbed, and skilled worker shortages have become more widespread (National Assembly of Vietnam, 2012). The country has to face many new social challenges including: poverty is becoming concentrated among ethnic minorities, rural-urban disparity is growing, land disputes and complaints are increasing and the pace of job creation is slowing. For example, according to the Vietnam Household Living Standards Survey 2010 conducted by Vietnamese General Statistical Office (General Statistic Office of Vietnam, 2010), the gap in monthly average income per capita of the richest household quintile and the poorest one was 9.2 times, increasing in comparison to the gap of previous years (8.1 times in 2002, 8.3 times in 2004, 8.4 times in 2006 and 8.9 times in 2008). These social problems, taken together, pose a serious threat to Vietnam's medium-term socioeconomic aspirations and the legitimacy of the Communist Party.

The reviewed negative signals of Vietnam macroeconomic situation over the past few years along with the low performance and inefficiency of the state economic sector summarized in the previous section have put fierce pressures on the Party and government for policy reforms in this state economic sector. The stressors have been revealed in a number of directives and legal documents of all levels of the regime 
from the Politburo, Party Central Committee, National Assembly, Central

Government, and the Ministry of Finance.

One of the first such efforts to reinforce reforms in SOE sector was undertaken on November 27, 2009 when the National Assembly issued Resolution No. 42/2009/QH12 on Increasing the Law Enforcement and Policy Implementation in Management, Resource Usage, Asset Management of SEGs and SGCs. This resolution strongly emphasized the weaknesses and problems of SOEs and called for more effective state management and restructuring of the sector. Notably, this resolution was produced right after an official investigation on the performance of SEGs and SGCs, which revealed serious problems of the state economic sector.

On July, 26, 2010, the Politburo of the Communist Party of Vietnam produced a special Conclusion No $78-K L / T W$ reiterated the demand for reforms in SOE sector and reinforced the previous resolutions of the CPV, including the Resolution on SOEs of the Third Plenum under the IX (2001) and the Socio-economic Development Resolution of the X Party Congress (2006). The conclusion admitted problems and difficulties of SOEs and the need for reforming and restructuring the state economic sector including "the backward legal framework, low efficiency of SOEs, high level of debts and insecure financial status, SOG large investments to non-core business areas, low technology application levels, low productivity, slow reform in internal enterprise management, low international competitiveness, and misalignment and misuse of government investments that were intended to promote higher levels of SOG competitiveness in the global economy" (Communist Party of Vietnam, 2010). In March 2011, the guiding Conclusion No 2-KL/TW on the Socio-economic Situation in 2011 identified several strategies to deal with the economic recession, 
including important changes in SOE practices. These changes included the requirement for "enhanced SOEs restructuring by equitization to SEGs; focusing on the core business areas of SEGs; not encouraging investment in non-core activities; clarifying the state ownership in SOEs; promulgation of more regulations to identify the accountability of individuals and organizations in using state resources" (Communist Party of Vietnam, 2011). The most recently approved Five-year National Socio-economic Development Plan 2011-2015 emphasized three areas that need urgent attention: restructuring of the state-owned enterprises (SOEs), improving the effectiveness of public expenditure and stabilizing the financial sector.

In December 2011, in response to the fierce pressures from the public and international organizations, the Ministry of Finance organized a conference on "Restructuring the Economy" chaired by the Minister of Finance. At the conference, the Minister of Finance, Vuong Dinh Hue, presented a keynote speech on "Solutions for Restructuring SOEs, with Emphasis on State Economic Groups and General Corporations". The Minister publicly admitted the seriously poor performance of SOEs and the pressures to reform this sector. After this conference, on July, 17, 2012, the Prime Minister promulgated Resolution No. 929/QD-TTg on "Program on Restructuring State-owned Enterprises with Emphasis on State Economic Groups and General Corporation in the period 2011-2015". Most recently, the $6^{\text {th }}$ Plenum under the XI Party Congress just finished on October 15, 2012, in response to the pressures on this sector and to the ongoing economic recession, the Vietnamese Party and government considered state-owned enterprise management as one of the three urgent issues of the Plenum. 
The above summary of actions undertake by the Party and government, coupled with the negative performance indicators of SOEs, clearly demonstrated that the CPV and government policy elites have recognized and felt the stressors for reform in the state economic sector. However, since state ownership is not just an economic issue but also a political choice, major restructuring of SOEs is unlikely without strong political support. Any restructuring plan would need to be firmly based on a clear consensus on the role of the state in the economy and the desirable institutional arrangements to achieve that goal. Thus, in the following section, I will review the critical Party and government documents involving the debate over the political role of SOEs in achieving the larger goals of the regime.

\section{Strong leadership predisposition to reform in state economic sector}

The leadership predisposition of the Vietnamese Party and government to restructure and reform the state economic sector can be traced back to the early 1990s when Vietnam started its economic reforms and international integration. In all of the resolutions, political reports, and five-year socio-economic plans issued at the VII, VIII, IX, X and XI National Party Congress, the Communist Party of Vietnam had mentioned the need to restructure the state economic sector. The goal was to equitize small and inefficient firms, to increase the performance of the SOEs, and consolidate the role of state economic sector in the national economy. This was deemed necessary in order to ensure a successful integration of the SOEs in the market-oriented economy especially when Vietnam accepted deeper trade liberalization since 2001. In August 2001, the Third Plenum of the Party Central Committee under the IX National Party Congress produced a special resolution guiding the development strategies and principles for state management of the state economic sector and the special role that 
SOEs would play in leading the national economy. This is the first special document of the CPV to emphasize the weaknesses of the SOEs and the predisposition to renovation in state management and restructuring of this sector. Notably, this resolution was promulgated right after Vietnam signed the Bilateral Trade Agreement with the U.S. in 2000 and accelerated the negotiation to join the World Trade Organization since 2002.

Since 2009 , the weak performance of the economy after the 2008 worldwide economic crisis coupled with poor performance, inefficiency and scandals in the operation of some SOEs created stronger pressures for the government to initiate reforms. The leadership demonstrated a stronger predisposition to respond to these pressures in a great number of directives and legal documents at all levels of the regime from the Party Central Committee, the National Assembly, the government, and its ministries.

On November 27, 2009, the National Assembly issued an alerting document: Resolution No. 42/2009/QH12 on Increasing the Law Enforcement and Policy Implementation in Management, Resource Usage, Asset Management of SEGs and State General Corporation. Earlier, a special Committee of the National Assembly had conducted an investigation on the economic performance of state general corporations and economic groups. Based on the results of the investigation, this resolution urged the government to implement a number solutions including: adjusting and completing the regulatory framework in the SOE sector; separating the ownership rights of the state and the administrative rights of the individual enterprises; continuing to evaluate the models of state general corporations and economic groups for important adjustments and reforms; accelerating the equitization 
process including the second tier companies within the state economic groups; and improve internal management within the SOEs (National Assembly of Vietnam, 2009).

On July 26, 2010, the Politburo produced a special Conclusion No. 78 $K L / T W$ on the Implementation of the Resolution of the Third Plenum at the Ninth Party Congress regarding reorganization, reform, and development of the SOEs. The conclusion continued to confirm the predisposition of the CPV to accelerate equitization and restructuring; improve the efficiency and the role of SOEs in the operation of the economy; and push for a breakthrough change in the near future (Communist Party of Vietnam, 2010). Again, the conclusion reiterated the demand for a completed legal framework, comprehensive auditing reports on the performance of SOEs, and acceleration of equitization.

In the following months, the Five-year Socio-economic Development Plan and the Conclusion No. 2-KL/TW on the Socio-economic Situation in 2011 called for "restructuring of SOEs by equitization to SEGs; focusing on the core business areas of SEGs; not encouraging investment in non-core activities; clarifying the state ownership in SOEs; and promulgating more regulations to identify the accountability of individuals and organizations in using state resources" (Communist Party of Vietnam, 2011). Among the three areas identified for urgent attention in the five-year socio-economic plan was restructuring of the state-owned enterprises.

Guiding by the Party, the Prime Minister issued a series of directives and decrees in 2011, in response to the pressures and criticisms of bad economic performance, especially in the state economic sector. On February 24, 2011, Government's Resolution No. 11/NQ-CP focused on the need to curtail the inflation 
rate, stabilize the macro economy, and ensure social welfare. Among the solutions, it mentioned the need to cut back on unnecessary investments of SOEs and restructuring low performing SOEs to save state budget. In March 13, 2011, Prime Minister's Decision on Standards to Classify the SOEs was produced to help the government classify different types of SOEs. This classification provided the basis for restructuring the state economic sector. On July 18, 2011, the Government Decree No. $59 / 2011 / N D-C P$ directed the transformation of some $100 \%$ state-owned enterprises into joint-stock companies.

In 2011, the Government charged the Ministry of Finance with the responsibility to build a Comprehensive Program on Restructuring the State-owned Enterprise Sector. Since then, conferences, hearings at the National Assembly and deliberations within the Party, government, and National Assembly agencies and committees have been conducted to seek ideas and consensus on the restructuring program. As a result of this process, on July, 17, 2012, the Prime Minister promulgated Resolution No. 929/QD-TTg on "Program on Restructuring State-owned Enterprises with emphasis on State Economic Groups and General Corporation in the period 2011-2015" and the Government Decree No.99/ND-CP on Dividing and Delegating Rights, Responsibilities, and Missions of the State Ownership in SOEs and State Investments in Enterprises in November 2012. These are the most updated and important document that clearly showcases the policy image and direction of the Party and government with respect to the role and management of SOEs.

To summarize, by reviewing the relevant Party and government documents in the state economic sector, we can discern a strong leadership predisposition to reform this sector. From the beginning Đổi Mới, the Party and government of Vietnam have 
shown continuous commitment to reform the SOEs. Most recently, in the $6^{\text {th }}$ Plenum of the XI Party National Congress just finished on October 15, 2012, restructuring SOEs was of the three focuses of the meeting. Notably, prior to 2010, the idea of restructuring the state economic sector was more concerned with the problems of low efficiency and competitiveness of SOEs while over the past two years, the Party and government have emphasized on the need to ensure the central roles of the SOEs especially those of SGCs or SEGs. Despite fierce pressures and strong leadership predisposition to reform, to date, no comprehensive reform and innovative policy has taken place. To explain this phenomenon, in the following section, I will review the policy image of the Party and government regarding the role and function of the state economic sector.

\section{The lack of significant change in policy image prohibits adoption of radical}

\section{policy change}

There is considerable evidence over the last 25 years following Đổi Mới that the Vietnamese Communist Party and government have continuously considered the state-owned enterprise sector as the dominant economic and political pillar of the regime. This is congruent with the fact that the Party and government have repeatedly emphasized the desire to create a market economy that preserves a Socialist orientation, the so-called "Socialist market-oriented economy". Since the early 1990s, along with developing a multi-sectorial ownership structure and moving toward a market-oriented economy, various resolutions of the CPV have always emphasized the leading role of the state economic sector. Neo-liberal advocates for free market economy may see a contradiction between the existence of a large state economic sector and a market economy, but in Vietnam the two goals were seen to be 
compatible (The Vietnam Consultative Group Meeting, 2011). A reading of the various resolutions of CPV suggests that its leaders did not necessarily see a conflict between the existence of a large state economic sector and market rules. Following are three main reasons for the Vietnamese Party and government's belief that state institutions needed to play a central role in the development of the market-oriented economy and the state needs to develop and control a strong state economic sector.

First, the central role of SEGs and SGCs has been justified as a tool for macroeconomic adjustment and to perform important social functions. For example, during periods of high inflation, the government has controlled the price of commodities and services provided by SEGs such as electricity (EVN), petroleum (Petro Vietnam), and coal (VINACOMIN). It has also instructed SEGs and state banks to reduce their investment in order to curb excessive demand and inflation rate. The charter of all parent companies of the SEGs lists a number of welfare and social responsibilities that have been assigned to them by the state. For example, the Vietnam Post and Telecommunication Group is responsible for providing telephone and internet services to isolated and remote areas, thereby facilitating local and national socioeconomic development. Similarly, Government Decree 101/2009/ND$C P$ has set several developmental goals for SEGs, including introducing new and advanced technologies in the country and facilitating the development of other industries and sectors of the domestic economy. Thus, by controlling the state economic sector, especially the SGCs and SEGs, the regime believed that it would be able to direct the cause of industrialization and modernization while maintaining Socialist goals and the political control of the CPV. 
Second, the Party and Government would like to emulate Korea and Japan in developing giant domestic enterprises, which receive intensive support and privileges from the government to increase their international competitiveness. Starting in 1991, the Resolution of the VII Party Congress asked to establish General Corporations (GCs) along with the development of a market-oriented economy and to build some big enterprise groups in order to attain sufficient prestige and competitiveness in foreign markets. In 1994, the VIII Party Congress gave clearer direction to concentrate state economic development resources in essential industries to create the so-called "iron punch - quả đấm thép". These industries included the social and economic infrastructure; financial, banking, and insurance system; important business productions and services; and the provision of products and services in the national defense and security sectors. In 2001, the Resolutions of the Third Plenum of the Party Central Committee under the IX Party Congress issued instructions for the establishment of SEGs, by selecting some of the general corporations that are strong enough to play a more catalytic role.

Especially since 2005, the government's decision to create state economic groups (SEGs) seems to have been hastened by its desire to achieve competitiveness in an increasingly globalized world. When Vietnam was preparing to join the World Trade Organization, its leaders feared that most domestic companies, including the SGCs, were too small and weak to withstand competition from foreign competitors. The government, therefore, moved decisively to establish SEGs and provide them with privileged access to state resources and autonomy to enable them to compete with foreign firms. This move was further strengthened by the idea that with a calibrated industrial policy in which the SEGs play a catalytic role, Vietnam could 
transform itself into a modern and prosperous country. Like Korea, Singapore, Taiwan, and China, in order for Vietnam to catch up and be competitive, it was believed that in the absence of a strong private domestic sector, Vietnam needed to develop strategic industries such as cement, oil, power, steel, telecommunications, and so forth; and this could be done only by large business groups with enough resources, capital, and technical capacity under close state control (The Vietnam Consultative Group Meeting, 2011).

The third reason for the Vietnamese Communist Party and government to believe in the central role of the SOEs is related to the nature of the state economic model. Indeed, ruling regime has not recognized the nature problems of state ownership as the main causes of poor economic performance within the sector. Leaders stand firms on their views that the problems of SOEs mostly come from the weaknesses of internal management and leadership within the enterprises. To resolve these administrative problems, only changes in regulations that increase accountability, transparency, and abiding rules are required. As the result, the recent guiding documents mostly focus on producing more regulation for a stricter state management in the state sector rather than on introducing a policy paradigm shift.

In recent years, however, after a series of scandals along with extremely negative results of investigations on SOEs, renewed questions have been raised about the actual role and capacities of SOEs, including state general corporations and economic groups. As reviewed in the previous sections, reports from Nationals Assembly and government have to admit that SOEs have taken advantage of weak oversight and transparency in the system, expanded their operation into areas beyond their core competency, mismanaged their finances, and concealed information from 
the government, thereby tarnishing the reputation of the entire sector (National Assembly of Vietnam, 2012). Critics also focused on the cronyism created by strong a connection between the SOEs and senior public officials. They also identified the responsibility of the government and the Prime Minister in the bad performance of SOEs. As a result, the National Assembly in one of its resolutions indicated that restructuring the SOEs should be a top priority of the government in the Five-year Socio-Economic Development Plan, spanning from 2011 to 2015. Does this call for a renewed reexamination of the role of state economic enterprises? Have the Party and government changed the policy image regarding the political, social and economic role of these institutions in securing the well being of the regime? In the paragraphs to follow, I will seek to answer this question.

On November 27, 2009, in response to the negative results of the report on the performance of SOEs made by the Oversight Committee, the National Assembly issued the Resolution 42/2009/QH12 on Increasing the Law Enforcement and Policy Implementation in Management, Resource Usage, Asset Management of SEGs and State General Corporation. In the Vietnamese state system, the investigations conducted by the National Assembly have always been considered as the most independent and objective public sources of information and this case was not an exception. The resolution urged for a reassessment of the model of state general corporations and state economic groups to bring about necessary institutional and policy reforms. Concretely, it pointed to a number of solutions to resolve the problems and difficulties of state general corporations and economic groups, including regulatory adjustments, separation between state ownership and institutional administration, separation between social missions and pure economic activities, 
improvement in internal governance and leadership; and equitization (National Assembly, 2009). However, the resolution still viewed the state general corporations and groups as important macroeconomic tools for domestic economy monitoring and for maintaining competiveness in the global economy.

In the same month of November 2009, the government promulgated Decree No. 101 on Pilot Establishment of State Economic Groups. The government's goals in establishing SEGs were: to concentrate the investments and mobilize resources to establish large scale firms in key economic areas in order to promote international competitiveness; to ensure the monitoring roles of the state economic sector within the whole economy; to promote the use of high-technology; and to create incentives for the development of other areas and the entire economy (Prime Minister of Vietnam, 2009). In reality, from 2005 to 2010, the government had started to accelerate the establishment of SEGs in key economic areas including: Vietnam Post and Telecommunications, Vietnam National Coal-Mineral Industries, and Vietnam National Textile and Garment (in 2005); PetroVietnam, Vietnam Electricity, Vietnam Shipbuilding Industry, Vietnam Rubber (in 2006); and Baoviet (in 2007); Vietnam National Chemical Group, Industrial Construction (in 2009); and Vietnam Housing and Urban Development (in 2010).

The establishment of SEGs was to realize the call for restructuring the SOEs guided by the previous Party's Resolution in 2001 (Communist Party of Vietnam, 2001). However, in the language of the CPV and its government, the word "restructuring" - "Tái cơ cấu" - does not mean that the Party will diminish the role of SOEs. Instead, it is to merge SOEs into the giant corporations and economic groups while abolishing or equitizing small and inefficient enterprises. This policy image was 
clearly explained by an elite policy maker, Minister of Finance, Vuong Dinh Hue at a conference on "Restructuring the Economy" in December, 2011. In his speech on "Solutions for Restructuring SOEs, with emphasis on State Economic Groups and General Corporation", Mr. Hue asserted: "restructuring is not to curtail the role of SOEs but to consolidate their functions and missions as the cornerstone of the Socialist-oriented economy" (Vuong, 2011). Accordingly, he said that restructuring should focus on five activities: (1) classification of economic areas that require significant state's ownership; (2) reassessment of the resource distribution within and among state enterprises; (3) renovation in the institutional governance of SOEs; (4) identification of an appropriate relationship between government and SOEs; and (5) establishment of a relevant legal framework.

In the middle of 2010, the giant Shipbuilder Economic Group (Vinashin) was officially going bankruptcy after it announced its incapacity to pay the debt amounting to 86,000 billion VND (around 4.3 billion USD). Nonetheless, a number of important documents of the CPV afterward continued to confirm the Party and government's policy image that SOEs needed to be preserved. Indeed, the Special Conclusion No. 78 - KL/TW of the Politburo on SOEs in July 2010, while admitting problems with state owned enterprises, concluded that "the Party's principles on the key role of SOEs in the national economy are proved to be correct" (Communist Party of Vietnam, 2010). The conclusion continued to attribute the constraints and problems of SOEs to the poor performance of the enterprises' leaders and the limitations of internal management capacity rather than blaming the ownership nature of SOEs. It also encouraged the development of the State Capital and Investment Corporations to facilitate restructuring SOEs and consolidate the role of the state in key economic 
areas. In 2011, the Socio-economic Development Plan 2011-2020, promulgated by the CPV as the guidelines for the development of the whole country in the long run, continued to affirm the need for the state economic sector to "play a central role as the important material force for the state to direct and monitor the economy, contributing the macroeconomic stability" (Communist Party of Vietnam, 2011).

At the government level, in 2011, the Prime Minister has taken several steps to respond to the fierce pressures from the public and international community to improve the performance of state owned enterprises. Following the Decision on Standards to Classify the SOEs, in March 13, 2011, the Government Decree No. $59 / 2011 / N Ð-C P$ was issued to direct the transformation of certain $100 \%$ state-owned enterprises into joint stock ones. The documents guide the process and procedures to transform some SOEs into joint-stock companies with multiple types of ownership in order to increase efficiency and performance. However, these documents did not provide radical changes in the assumed view that state owned enterprises are essential to the well being of the economy and the state. Instead, they only aim at consolidating the role of the state in key economic areas and to strengthen their performance. The government only wants to equitize SOEs whose business activities are key economic areas based on the state's definition.

In the same direction of change, most recently, on July, 17, 2012, the Prime Minister issued the Resolution No. 929/QD-TTg on "Program on Restructuring Stateowned Enterprises with emphasis on State Economic Groups and General Corporations in the period 2011-2015". The resolution identifies areas in which the government retains $100 \%$, over $75 \%$, from $60-75 \%$, from $50-65 \%$ of the total enterprise's charter capital. The other types of SOEs will be equitized. Table 12 
describes ideas of government in restructuring the state economic sector. Following guidelines of the Party produced at the $6^{\text {th }}$ Plenum of the XI Party National Congress in October 2012, the government promulgated Decree No. 99/ND-CP on Dividing and Delegating State Ownership Rights and Responsibilities in SOEs and State Investments in November 2012. The decree is to clarify the roles and responsibilities of different public authorities in the state management over the SOE sector and to delegate some power from the central government of the line ministries and provincial authorities. The decree continues to confirm the will of the state to invest in key business areas of the economy in order for the state economic sector to maintain the leading role and for the state to monitor the economy.

Table 12: Categorization of state-owned enterprises based on Prime Minister's Resolution No. 929

\begin{tabular}{|l|l|l|}
\hline $\begin{array}{c}\text { Type of } \\
\text { enterprises }\end{array}$ & $\begin{array}{c}\text { Percentage of charter } \\
\text { capital charter retained by } \\
\text { the state }\end{array}$ & \multicolumn{1}{c|}{ Business areas or activities } \\
\hline 1 & $100 \%$ & $\begin{array}{l}\text { National defense, security, publishing; irrigation, } \\
\text { transportation security, lottery, electricity production at } \\
\text { a large scale and important to national security and } \\
\text { defense, infrastructure development and management in } \\
\text { the railroad sector and urban development sectors, } \\
\text { airport, sea ports, and currency printing. }\end{array}$ \\
\hline 2 & 75 to $100 \%$ & $\begin{array}{l}\text { Natural resource exploitation and process; } \\
\text { telecommunication service provision }\end{array}$ \\
\hline 3 & $65-75 \%$ & $\begin{array}{l}\text { Chemical and fertilizer productions, agriculture product } \\
\text { trading, pharmacy trading, financing and banking, } \\
\text { insurance, water process and delivery, urban } \\
\text { development in big cities, agriculture seeding } \\
\text { production, vaccine production, road system } \\
\text { management and repair, see port management and } \\
\text { exploitation, electricity production at large scale, } \\
\text { railway and airway development }\end{array}$ \\
\hline 4 & $50-65 \%$ & \begin{tabular}{l} 
Based on the circumstance and market place \\
\hline
\end{tabular} \\
\hline
\end{tabular}

In addition to the reviewed official documents, the policy beliefs and images of the Vietnamese Party and government regarding the role and function of SOEs have also been expressed in the policy statements and interviews of the policy elites. 
On May 21, 2012, the Minister of Planning and Investment presented at a National Assembly meeting a Master Plan on Restructuring the Entire Economy. Among the targets of economic restructuring was the state economic sector. The declared goal of restructuring was to change the administrative and resource distribution mechanism, to improve the efficiency and competitiveness of SOEs, especially the general corporations and economic groups, in order for them play a better role and to perform more efficiently and effectively within the national economy. In order to restructure the state economic sector, the Master Plan focused on (1) reassessing the roles and functions of SOEs in order to classify and categorize different types of SOEs; (2) renovating administrative governance within the individual enterprises; (3) imposing market and state rules on the operation of SOEs and (4) introducing more competition into the state economic sectors (Bui V. Q., 2012).

In addition to the beliefs in the central role of SOEs, the policy elites have not seen the nature of state ownership as the key reason for the low performance of the state economic sector. For example, in a hearing focusing on the poor performance of SOEs in front of the National Assembly on June 15, 2012, Deputy Prime Minister, Nguyễn Xuân Phúc, cited a report produced by the State Bank of Vietnam which concluded that the debt and loss rate of the state general corporations and economic groups are not high and not the reason for the existing high percentage of bad loans of the banking system. The Deputy Prime Minister referred to the lack of administrative regulations and oversights over the SOEs, along with incompetent leadership of some SOEs, as the main reasons for the low performance. Instead of looking at the ownership nature of the SOEs, he argued for more transparency and oversight as the way to improve the performance of the SOEs (Nguyen X. P., 2012). Another example 
is Nguyễn Đức Kiên, Deputy Chair of National Assembly's Economic Committee. At a press conference organized by the General Accounting Office on July 19, 2012, in his report on the performance of SOEs, Mr. Kien while recognizing the low performance of some SOEs highlighted the achievements and efforts of the SOEs in the past few years in the midst of the world financial crisis. He attributed the ongoing worldwide financial crisis as the main reason for the difficulties of the SOEs including Vinalines Group as a victim of the crisis.

To summarize, over the past two decades, the regime of Vietnam repeatedly emphasizes the need for restructuring the state economic sector to make the SOEs more efficient and effective. In fact, the Party and government of Vietnam have accepted a number of incremental changes over the past few years, including the issuance of the legal framework for equitization including Decree No. 59, Decision No. 929, and Decree No 99. However, similar to the case of higher education, the state-owned enterprises policy case has not seen any significant change in the policy image of the Party and government regarding the role and function of the SOEs. The Party and government stand firm on their perception on the central roles of the state economic sector especially the SEGs and SGCs as the leading forces of the national economy. The state continues to consider SOEs as effective and necessary macroeconomic instruments for the state to monitor the economy and to ensure the social welfare system.

Even after the recent scandals related to the SEGs and SGCs, the regime does not see any conflict between the existence of a large state economic sector and the development of a market-oriented economy and deeper international economic integration to the world economy. According to this view, all economic sectors can 
develop together and contribute the socio-economic development of the country. Also, the regime has not perceived the nature problem of the state-owned enterprises operating in a market economy. Instead, leaders have continued to attribute the weaknesses and problems of enterprise governance and of internal management as the key reasons for low performance. As the result, the main solution to the state economic sector is not to resize this sector or to focus on the areas where the market fails. Instead, policy changes have focused on providing a stricter state oversight over the enterprises and improvement in enterprise operation and management. Due to the lack of significant change in the policy image of the Party and government in this policy area, no innovative policy change initiative has been advanced and discussed within the regime. Therefore, we do not need to examine the forth policy factor of the proposed policy change model as the case of international trade reform in Chapter VI.

\section{Conclusion on the relevance of the proposed Policy Model to the case}

Vietnam has traditionally chosen a step-by-step or gradualist approach to reform rather than initiating "big bang" solutions to address its socio-economic problems. This approach is unlikely to change when it comes to reforming the SOEs, especially given the superior status granted to the state economic sector under the Socialist legacy of the regime. The CPV defined the "Socialism-oriented" economy as a multi-sectorial economy, operating under the market rules and led by the state (Communist Party of Vietnam, 2001). By employing the policy factors and causal flow of the proposed major policy change model for Vietnam, we can understand why reaching a comprehensive reform in the state economic sector will be difficult and take considerable time. 
Over the process of Đổi Mới, the Communist Party of Vietnam and its government have been aware of the need to improve the performance of the state economic sector. However, the lack of significant change in the policy image on this sector is the impediment for a radical and innovative policy change. Concretely, the Party and government of Vietnam have not changed their policy images on the roles and functions of the state economic sector in several aspects. First, the Party and government have continued to consider SOEs the cornerstone of national economic development, providing the state with effective macroeconomic instrument. The ruling regime still believes that without a large scale and strong state economic sector, the state cannot retain control over the industrialization process of the country to ensure that the market serves the Socialist-oriented goals. Second, the policy elites continue to attribute the origin of the problems of SOEs to the weaknesses of internal administration and leadership within individual enterprises instead of the problematic nature of state ownership. Thus, incremental internal governance policy changes such as a more transparent and stricter legal framework can help deal with immoral and corrupt enterprise executives and promote the health of SOEs. Third, the Vietnamese Party and government still have not recognized any fundamental conflict between a large scale and strong state enterprise sector and a market economy. The regime believes that on the one hand the state can consolidate the state economic sector while at the same time promoting the development of the private sectors. Fourth, the government continues to reaffirm that the critical roles of the SOEs are to maintain the legacy of a socialist government by providing essential state welfare services. By controlling essential consumer products and public services, the state can ensure social equality and support to the poor and disadvantaged people. 
Similar to the case of higher education policy, the legacy of the Socialist state prohibited the formulation of innovative policy change initiative in state-owned enterprise reform even when Vietnam has adopted many radical changes in other policy areas during Đổi Mới. The CPV continues to consider SOEs, especially state general corporations and economic groups as the instruments and resources for the Party to direct the Socialist market-oriented economy. This view is congruent with Marxist and Leninist ideology that the social class, which controls the means of production will be able to control politics and to lead the society. All of the above policy beliefs and political judgments have dominated the fact that SOEs have been much less efficient and effective compared to other sectors. Thus, the evidence in this case study proves proposition 4 of the policy model that political judgments can override efficient concerns in the policy-making process in Vietnam. In order to pave the way for a radical policy change in state management of the state economic sector in the future, the Party and government of Vietnam must first change their policy images and beliefs about the effectiveness and the roles of the state economic sector. 


\section{Chapter VIII: A Radical Legal Change in Foreign Investment in Response to the Stressors from WTO Accession}

In 2005, the Vietnamese government accepted a great deal of legal reforms with the goal of establishing a favorable business environment for all types of enterprises doing business in Vietnam. An important question posed by these reforms is why they occurred so quickly and easily compared to the slow and relative absence of major policy change with respect to state-owned enterprise policy discussed in the previous chapter. At the surface, some may see a divergence between these swift radical reforms and the tradition of "gradualism" in policy reform in Vietnam. In this case study, I hope to provide the evidence to answers to this question which in turn can help shed light to the policy process of Vietnam as well as to validate the major policy change model proposed in Chapter III.

Since the main goal of the case studies in this dissertation is to validate the explanatory capacities of the proposal policy model, I am selecting the legal reform in the areas of foreign investment represented by the integrative Investment Law adopted in 2005 as subject of analysis. In addition, I will narrow down the analysis to the process in which the Vietnamese government step by step created an equal playing field for enterprises of all economic sectors including the foreign-owned enterprises. By examining the changing process in creating a favorable environment and equal legal status for the foreign invested enterprise sector, I hope to shed light on the role of policy factors to the policy process and its outcomes in this policy domain since Đổi Mới in 1986. 
The Investment Law was promulgated in 2005 to replace the Domestic Investment Promotion Law of 1998, the Foreign Direct Investment Law of 2000 and the investment provisions of the Enterprise Law of 1999 and of the Law on Stateowned Enterprises of 2003. Generally, the new Law created an integrative legal framework for all kinds of investment activities in Vietnam. The expressed purpose of the law was to remove all forms of legal discrimination between public, private and foreign-owned enterprises and to recognize equal rights and obligations of all types of enterprises, regardless ownership. The law provided for greater autonomy and incentives for foreign-owned enterprises doing business within the territory of Vietnam.

I will organize my analysis in this case into three parts. In the first part, I will review the macroeconomic performance of Vietnam during the years prior to the adoption of the integrative Investment Law of 2005. This section will provide the reader with an understanding of the background for my analysis of the policy change process in the second section of this chapter. In the second section, I will employ the key policy factors embedded in the major policy change model for Vietnam to explain why the Vietnamese government decided to adopt the Investment Law of 2005 in a quick and decisive way after a decade and half of incremental changes. My main argument is that due to the pressures to meet the requirements for WTO accession, the government finally promulgated the Investment Law along with other legal reforms such as the integrative Enterprise Law. In the last section, some conclusions on the applicability of the proposed major policy change model for Vietnam will be drawn. 


\section{Vietnam economic performance prior to 2005 and key legal changes in the area of foreign investment in Vietnam}

The two years of 2004 and 2005 witnessed strong recovery and very positive indicators of the Vietnamese economy after a period of downturn and recession since the Asian Financial Crisis in 1997. Continuing the trend toward deeper integration into the global economy gradually helped Vietnam to regain the growth momentum of the first half of the last decade. Real GDP growth in 2005 rose to 8.4 percent per year, the highest rate since 1997, making the GDP per capita of US\$630, more than four times the US\$146 GDP rate in 1990 (Chu \& Dickie, 2006; Luong, 2006). The total value of exports of goods and services increased by 23 percent a year, reaching the level of US\$36.5 billion in 2005, compared to US\$0.9 billion in 1986. Foreign direct investment (FDI) grew continuously with increases in both commitments and disbursements. Investments totaled almost $\$ 6$ billion of registered capital in 2005, reaching its highest level since 1997 (Luong, 2006).

Private sector investment continued to expand rapidly in response to an increasingly favorable business environment in the aftermath of the Enterprise Law of 1999. About 40,000 new enterprises were registered in 2005, representing a year-onyear increase of 9 percent in number and 45 percent in registered capital (Chu \& Dickie, 2006). The real GDP originating from the industrial sector increased by 10.7 percent among which the manufacturing subsector rose more rapidly at 13.0 percent. Services sector growth increased to a record of 8.5 percent in 2005 , which was the first time the sector had grown higher than the overall GDP growth (Chu \& Dickie, 2006). Although the agriculture sector in 2005 was adversely impacted by drought, a typhoon and the resurgence of avian flu, resulting in a loss of about 0.7 percent of 
GDP, spurred by rising international prices of agricultural products, the sector managed to overcome these difficulties to register a four percent growth in value (Chu \& Dickie, 2006).

The strong economic growth rate had fiscal consequences for Vietnam in the years preceding the passage of the 2005 Investment Law. Driven by rising food and fuel prices and facilitated by an accommodative monetary policy, the inflation rate increased to $9.6 \%$ in 2004 and $8.4 \%$ in 2005 (Luong, 2006). However, the inflation rate was under the control of the government. The government's policy of stimulating the economy through increased governmental spending accounted for an annual budget deficit of between $4 \%$ and $5 \%$ of gross domestic product (GDP) since 2001 (Luong, 2006). But this rate was still acceptable. By 2004, total external debt only amounted to US\$15.5 billion, just over 34 percent of GDP and 52 percent of the total exports of goods and services (Chu \& Dickie, 2006). A large proportion of the debt remained on concessional terms (just under US\$3 billion had been contracted by the private sector).

The rapid economic growth of the economy was accompanied by a sharp reduction in poverty. According to the poverty standards of the Vietnamese government, the poverty rate declined substantially from 58 percent in 1993 to 19.5 percent in 2004 (Chu \& Dickie, 2006). As a consequence, the World Bank, IMF, Asian Development Bank and other international institutions praised Vietnam for its successes in poverty reduction and alleviation (cited in Meyer, Tran, \& Nguyen, 2005). Key human development indicators for education and health, such as life expectancy, also improved significantly during this period. 
The economic performance prior to the passage of the 2005 Investment Law was positive and Vietnam seemed to enjoy a strong recovery from the Asian Financial Crisis in the period from 2002-2005. Under these circumstances, some may think that the Vietnamese government would not be pressed for further economic reforms. However, when we look at the governance agenda of Vietnam in 2005, a great deal of legal reforms were discussed and hastily adopted. Many kinds of law, which had been only incrementally revised in previous years were quickly and dramatically changed by the government in a short period of time. The following section will review in detail the changing legal environment, especially in the policies that established the equal status for different types of enterprises operating in the various sectors of the economy.

\section{Policy process in setting the equal legal status for all types of enterprises}

One cannot fully understand the legal changes made in 2005 without putting it in the larger context of policy changes initiated by Đổi Mới in 1986. The first phase of Đổi Mới was characterized by the recognition of a market-oriented and multi-sectorial economy. The CPV and government recognized private ownership as an integrative component of the economy, accepted trade liberalization and encouraged foreign investment. A major goal of Đổi Mới was to loosen the restrictions on private firms and attract significant external resources from other countries to foster industrialization. The results of economic development since Đổi Mới have raised the people's living standards and modernize the country, which in turn was thought important for ensuring the political stability and leadership by the CPV.

The changes in the mindset initiated by Đổi Mới spawned a great deal of progressive changes in Vietnam's legal framework. For example, during the period 
1987-1996, a new constitution was adopted (in 1992) and over 100 laws, including a Civil Code, were enacted (Ministry of Industry and Trade of Vietnam, 2003). The first cornerstone of the legal framework for the new market economy was the Foreign Direct Investment (FDI) Law promulgated in December 1987. The FDI was welcomed in all economic sectors and for the first time the law permitted 100 percent foreign ownership companies operating in Vietnam; generous tax and duty exemptions were provided, and unrestricted repatriation of capital was guaranteed (Chu \& Dickie, 2006). This FDI legislation was very progressive for its time. It served over the years to attract new investments, provide international market access for export-led development and stimulate infrastructure development in Vietnam by the infusion of significant investments of foreign capital. In 1992, the Law was amended, granting foreign investors more incentives and benefits such as allowing more forms of investment, longer land use terms, and tax reductions (Vu H. T., 2010). The second significant legal reform was the introduction of the Private Enterprises Law and the Law on Companies in 1990. Through these laws, the Vietnamese Party and government officially recognized the importance of the private economic sector and set the regulatory framework for the establishment and operation of businesses in this sector. Regarding international trade, according to the 1990 laws, private enterprises which satisfied a number of conditions and obtained an import license from the respective authority were allowed to engage in import-export activities. However, due to the complication of the licensing procedure, only a small number of private enterprises were licensed to engage in direct import-export activities. 
In the years following the passage of the 1990 laws, the government continued to revise the initial legal frameworks to create a freer business environment and to integrate deeper into the world economy. The Foreign Direct Investment Law of 1987 was revised two times in 1990 and 1992 and then replaced by the new Foreign Direct Investment Law in 1996. Vietnam joined the ASEAN Free Trade Area (AFTA) in 1995 and started negotiation with the United States for the Bilateral Trade Agreement in the same year. Also, in 1995, Vietnam initiated WTO accession and planned to join this organization in 2005. In order to legalize the establishment and management of state-owned enterprises, which were previously regulated only by decrees and directives of the government, in 1995, Vietnam promulgated the Law on State Enterprises. According to this law, state-owned enterprises were to be organized and managed by different models compared to companies operating in the private sector.

In response to fierce competition from the countries in the region after the Asian Financial Crisis in 1997, the Vietnamese government leaders were pushed to accept the second phase of legal reforms by creating more favorable conditions for FDI by the revision of the 1996 Foreign Direct Investment in 2000. The import-export license was abolished by Decree No. 57/1998/ND-CP in 1998 and the 1999 Enterprises Law, which stipulated that all registered enterprises were allowed to engage in international trade. The integrative Enterprise Law replaced the 1990 Private Enterprise Law and the Law on Companies. In 2003, the government also revised the Law on State-Owned Enterprises, first promulgated in 1995.

Despite significant legal changes in the 1990s, the various economic legal frameworks in Vietnam were still suffered serious limitations and inequities, especially between the state-owned enterprises and their non-public counterparts as 
well as between domestic and foreign firms. For instance, foreign investment activities were viewed with suspicion by the Vietnamese government, which was reflected in onerous licensing requirements, restrictions on hiring local attorneys and legal advice to international law, and, occasionally, interfering with such basic aspects as renting office space and obtaining telephone lines (Ministry of Industry and Trade of Vietnam, 2003). Mergers and acquisitions involving foreign companies were still very limited. For example, a foreign investor was prohibited from buying more than $30 \%$ of shares of equitized SOEs even in SOEs of the same industries where foreign investors could fully own an enterprise. Joint ventures with domestic private companies required a special licensing procedure that was much more time consuming and more difficult than the licensing procedures for a wholly owned domestic company. Distribution rights were restricted and a required percentage of locally produced parts was imposed on manufacturing firms despite the limited development of domestic suppliers. A number of industries and markets were not yet open to foreign investors. While the 1987 Foreign Investment Law was considered progressive for its time, by the beginning of the new millennium the law was no longer competitive compared to other regional investment laws (Le D. D., 2002).

In addition to a constraining legal framework, the high costs of doing business in Vietnam served as an additional barrier to foreign investors. For example, the high cost of international telephone calls, Internet fees, and seaports compared to other regional countries was a disincentive to foreign investors ( (Le D. D., 2002). Notably, Vietnam still had a dual price system for foreign investors in place into the $21^{\text {st }}$ century and applied separate laws to foreign investors from those it applied to domestic investors. For example, corporate tax rates and personal income tax rates 
(50\% of the gross income) for foreign-owned enterprises were well above the regional average (Le D. D., 2002).

At the beginning of the new $21^{\text {st }}$ century, competitive pressure on the global front, coupled with domestic pressure to attract more foreign investment, forced the Vietnamese government to consider abolishing its discriminatory treatment of domestic and foreign enterprises and of the rules governing the operation of businesses in the different sectors of the economy. The pressure was reinforced by the commitments that Vietnam made under international agreements, in particular the Vietnam-US Bilateral Trade Agreement coming into effect in 2002, the ASEAN Free Trade Area (AFTA) agreement by 2006 and the WTO agreement in 2005. Together, these agreements required Vietnam to demonstrate a strong commitment to alter its domestic legal framework in order to operate within the global economic community.

As a result of both internal and external pressure, in November 2005, the new integrative Law on Enterprises and Investment Law were adopted to harmonize investment/registration procedures for foreign and domestic enterprises. The Investment Law replaced the Foreign Investment Law of 1996 and 2000 and the Domestic Investment Promotion Law of 1998, and parts of the Enterprise Law of 1999 and the Law on State-Owned Enterprise of 2003. Under the new law, foreign and domestic enterprises are treated equally according to the rule of nondiscrimination under WTO (Muller, 2002). The law removed the constraints on foreign-owned enterprises in importing goods related to their business lines or specified in their investment certificate, and removed restrictions on importing goods of the same kind as those produced under the investment license (Pham H. T., 2011). 
The following Table 13 summarizes all of the legal reforms in investment that were put in place after Đổi Mới in 1987 up until the passage of the 2005 Investment

Law. The consistent pattern of incremental change occurring over this nearly 20 year

period raises the question of why a new comprehensive law was needed and

decisively adopted in 2005 .

Table 13: Summary of legal changes in Vietnam's foreign investment from 1987-2005

\begin{tabular}{|c|c|c|c|}
\hline No & Name and Date & Major contents of Laws & Policy implication \\
\hline 1 & $\begin{array}{l}\text { December, 1987: } \\
\text { Foreign Direct } \\
\text { Investment Law } \\
\text { (FDI) }\end{array}$ & $\begin{array}{l}\text { This FDI legislation officially } \\
\text { opened the door for international } \\
\text { economic integration by attracting } \\
\text { foreign investments and accessing } \\
\text { international markets for Vietnam's } \\
\text { export-led development. }\end{array}$ & $\begin{array}{l}\text { Continuously revised. In } 1990 \text { \& } \\
1992 \text { more rights and incentives } \\
\text { given to foreign companies. In } 1992 \\
\text { a number of articles were added and } \\
\text { amended, allowing FDI to } \\
\text { participate in the construction of } \\
\text { infrastructure facilities, giving the } \\
\text { same tax treatment between joint- } \\
\text { ventures and wholly foreign-owned } \\
\text { enterprises, and longer term of land } \\
\text { use }\end{array}$ \\
\hline 2 & $\begin{array}{l}\text { December, 1990: } \\
\text { Company Law } \\
\text { and Law on } \\
\text { Private } \\
\text { Enterprises }\end{array}$ & $\begin{array}{l}\text { These laws are considered as the } \\
\text { first legal documents to recognize } \\
\text { private ownership and guide the } \\
\text { establishment of private companies } \\
\text { including limited, joint-stock and } \\
\text { private models. }\end{array}$ & $\begin{array}{l}\text { These laws implemented a paradigm } \\
\text { shift away from a state controlled } \\
\text { economy to a mixed economy of } \\
\text { private and public ownership of the } \\
\text { means of production. }\end{array}$ \\
\hline 3 & $\begin{array}{l}\text { April, 1995: Law } \\
\text { on State } \\
\text { Enterprises }\end{array}$ & $\begin{array}{l}\text { This law legalized the establishment } \\
\text { and management of state-owned } \\
\text { enterprises, which were previously } \\
\text { regulated only by decrees and } \\
\text { directives of the government. }\end{array}$ & $\begin{array}{l}\text { The law established different } \\
\text { models for establishing and } \\
\text { managing state-owned enterprises. }\end{array}$ \\
\hline 4 & $\begin{array}{l}\text { November, 1996: } \\
\text { New Foreign } \\
\text { Investment Law }\end{array}$ & $\begin{array}{l}\text { Replaced series of laws governing } \\
\text { foreign investment with a new } \\
\text { comprehensive and organic law that } \\
\text { outlined rights and incentives to } \\
\text { foreign investors and companies, } \\
\text { including: the right to assign the } \\
\text { contributed capital to other parties } \\
\text { or to engage in new forms of } \\
\text { investment including BOT (Build- } \\
\text { Operate-Transfer), BTO (Build- } \\
\text { Transfer-Operate), and Build- } \\
\text { Transfer (BT) contracts. }\end{array}$ & $\begin{array}{l}\text { This law notably retained a number } \\
\text { of restrictions that limited the } \\
\text { control of foreign investors such as } \\
\text { the principle of unanimity in the } \\
\text { board of management and the } \\
\text { requirement to purchase local } \\
\text { products and services. } \\
\text { In } 2000 \text { the Law was amended and } \\
\text { modified again to acknowledge the } \\
\text { right of foreign investors to merge } \\
\text { and acquire companies and } \\
\text { branches, and the right to transfer } \\
\text { the form of investment. }\end{array}$ \\
\hline 5 & $\begin{array}{l}\text { June, 1998: Law } \\
\text { on Domestic } \\
\text { Investment }\end{array}$ & $\begin{array}{l}\text { Set a framework to encourage the } \\
\text { domestic investment from the } \\
\text { Vietnamese citizens who inside or } \\
\text { outside Vietnam and foreign people } \\
\text { who live inside Vietnam. }\end{array}$ & $\begin{array}{l}\text { The law indicates the existence of } \\
\text { separate legal frameworks for } \\
\text { different economic sectors at the } \\
\text { end of } 1999 \mathrm{~s}\end{array}$ \\
\hline
\end{tabular}




\begin{tabular}{|c|c|c|c|}
\hline 6 & $\begin{array}{l}\text { June 1999: } \\
\text { Enterprise Law }\end{array}$ & $\begin{array}{l}\text { This law replaced several previous } \\
\text { laws regulating different kinds of } \\
\text { economic enterprises and broadened } \\
\text { the rights and powers of profit- } \\
\text { oriented companies, both domestic } \\
\text { and foreign-owned. }\end{array}$ & $\begin{array}{l}\text { This law was a critical step in the } \\
\text { process of integrating the legal } \\
\text { framework for business activities in } \\
\text { Vietnam. }\end{array}$ \\
\hline No & Name and Date & Major contents of Laws & Policy implication \\
\hline 7 & $\begin{array}{l}\text { November, 2003: } \\
\text { Revised Law on } \\
\text { State Enterprise }\end{array}$ & $\begin{array}{l}\text { This law replaced the } 1995 \text { Law on } \\
\text { State Enterprise and provided three } \\
\text { models of state-owned enterprises: } \\
\text { state-owned enterprise, state-limited } \\
\text { enterprise, and state joint-stock } \\
\text { enterprise. The two later models } \\
\text { were close to the models of private } \\
\text { companies regulated in the } \\
\text { Enterprise Law of } 1999 .\end{array}$ & $\begin{array}{l}\text { This law blurred the boundaries } \\
\text { between state-owned enterprises and } \\
\text { the domestic private ones in terms } \\
\text { the rules governing their } \\
\text { establishment and operation. }\end{array}$ \\
\hline 8 & $\begin{array}{l}\text { December, 2005: } \\
\text { New Enterprise } \\
\text { Law and New } \\
\text { Investment Law }\end{array}$ & $\begin{array}{l}\text { The Enterprise Law of } 2005 \text { unified } \\
\text { the procedures of establishing and } \\
\text { managing enterprises regardless } \\
\text { ownership. This Law replaced the } \\
\text { Enterprise Law of } 1999 \text {, the Law on } \\
\text { State-owned Enterprises of } 2003 \text {, } \\
\text { and parts of the Foreign Investment } \\
\text { Laws of } 2000 \text {. } \\
\text { The Investment Law of } 2005 \\
\text { replaced the Foreign Investment } \\
\text { Law of } 2000 \text {; the Law on Domestic } \\
\text { Investment Promotion of } 1998 \text {, and } \\
\text { parts of the Enterprise Law of } 1999 \\
\text { and the Law on State-owned } \\
\text { Enterprises of } 2003\end{array}$ & $\begin{array}{l}\text { These two laws introduced } \\
\text { significant changes to the rules } \\
\text { governing private, state-owned, and } \\
\text { foreign-owned enterprises. It } \\
\text { removed preferential treatment of } \\
\text { state-owned enterprises and put in } \\
\text { place the conditions required for } \\
\text { accession to the WTO. }\end{array}$ \\
\hline
\end{tabular}

\section{Analysis of the policy change process in establishing equal playing field for}

\section{foreign-owned enterprises in Vietnam}

This section will look deeper into the policy process to explain why Vietnam enacted changes to accept an integrative Investment Law in 2005. As mentioned in my introduction to this chapter, I will only focus on the policy efforts to establish level playing field for foreign-owned enterprises to be established and operated in Vietnam. To examine the policy change process, I am going to employ to key concepts of the proposed major policy change model in Chapter III. As with my discussion of the policy change process in the case studies presented in previous chapters, my goal is not to evaluate the policy outcomes. Instead, the goal is to 
understand the role the various policy factors accounting for the initiation, formulation and adoption of major policy change in the area of foreign investment. I am interested in understanding why major change occurs in 2005 , not earlier or later.

\section{The role of stressors in initiating foreign investment legal reform}

As reviewed in section one of this chapter, the macroeconomic situation of Vietnam in the years preceding the adoption of the 2005 Investment Law was very positive. The economy had recovered from the downturn caused by the Asian Financial Crisis. On the surface, there appeared to be a lack of economic stressors that trigger the major legal reforms adopted in 2005 . However, while there may not have been strong internal economic pressures, there were strong external stressors from the international economic commitments especially from the application to the WTO.

Indeed, the high economic growth after Đổi Mới was attributed to the strong growth of export and foreign investment which in turn depended on the level and depth of Vietnam integration into the world economy. The international integration process required Vietnam to establish a set of favorable business conditions for foreign investors and enterprises. Vietnam realized this requirement, which accounts for the gradual and consistent series of changes that occurred during the 1987-2005 period summarized in table 13 . But the changes that occurred over nearly a 20 -year period were not sufficient to meet the criteria for Vietnam's entry into the WTO. As the summary makes clear, the incremental changes still left state-owned enterprises and non-foreign investors with preferential treatment that was inconsistent with membership in the WTO.

Becoming a member of the WTO, as discussed in Chapter VI, was a high priority for the Vietnamese Party and government. But this goal could not be achieved 
without making significant additional reforms to harmonize the legal system with the fundamental principles of international laws. The pressure for legal reforms increased especially after Vietnam signed the important Bilateral Trade Agreements (BTA) with the USA, which came into effect from December 2001.

In accordance with this BTA, Vietnam had to commit itself to the following reforms: (i) to reduce tariffs and eliminate trade barriers to U.S. exports, (ii) to provide protection and enforcement for U.S. intellectual property rights, (iii) to open Vietnam's services market to US companies, and (iv) to create fair and transparent rules and regulations for U.S. investors (Pham H. T., 2011). The implementation of the BTA with the U.S. was important itself because it would help attract U.S. investors and open a largest export market for Vietnam's products. But more important, the BTA was a good opportunity for outside observers to test the willingness of the Vietnamese government to make the reforms needed for admission into the WTO. As pointed out in my discussion of the BTA with the U.S. in Chapter VI, after a period of internal intensive debates and deliberation, Vietnam accepted the Agreement. The BTA marked a period when Vietnam stood firm on deeper economic reforms, especially when FDI from the U.S. to Vietnam rapidly increased starting in 2002, attracting 209 projects, with the U.S. having the $11^{\text {th }}$ largest foreign investment in Vietnam in 2004. (Meyer, Tran, \& Nguyen, 2005).

To become a member of WTO, economic and legal reforms made by the candidate nation would become irreversible (Ministry of Industry and Trade of Vietnam, 2003). From March 1998, WTO members sought clarification on Vietnam's policies and institutions not only about its trade policies and practices but also about the institutional and legal structure of the economy, the degree of privatization and the 
ability of the government to live up to the commitments it makes to the WTO (Nguyen \& Haughton, 2002). Guaranteed by the BTA with the U.S., the WTO started the final phase of negotiation with Vietnam in April 2002. Earlier, Mike Moore, President of WTO, on a visit to Vietnam in November 2001, demonstrated support for helping Vietnam become a member of WTO but emphasized that approval depended mainly on the effort Vietnam put into making the necessary changes to its policies and procedures (Nguyen \& Haughton, 2002). Thus, undertaking reforms was a prerequisite for Vietnam WTO membership. Vietnam needed to show its continued commitment to institutional reform even when it had furthered reforms in response to the Asian Financial Crisis in the period from 1998 to 2001.

Despite the continuing bilateral and working party negotiations, by 2004 the focus of implementation had changed from the BTAs that Vietnam had signed with member countries of WTO to what Vietnam was doing domestically with regard to enacting national laws, ordinances, and regulations (Ministry of Industry and Trade of Vietnam, 2003). Accordingly, the Working Party, which was a committee assigned by the WTO to work with the Vietnamese Negotiation Delegation, insisted that Vietnam needed to enact essentially all the legislation that the Working Party deemed necessary for implementing Vietnam's accession obligations before accession was granted for review, in English translation, by the Working Party (Ministry of Industry and Trade of Vietnam, 2003). Presumably, this reflected some dissatisfaction with Vietnam regarding the speed with which it was proceeding to meet WTO expectations compared to the progress of legal reform made by China before it was admitted to WTO in November 2001. 
Other domestic pressures reinforced the pressures for legal reforms from the WTO. According to Le Dang Doanh (2002), despite tangible improvement over the years after Đổi Mới, especially the Enterprise Law in 1999 and the liberalization of trade through the BTA with US and other countries, legal regulations in Vietnam were fast changing and becoming less predictable and less consistent, especially in tax, foreign exchange, labor regulation, land and jurisdiction. For example, customs officers in different seaports could apply different tax rates to the same products. As a result, red tape, bureaucracy, inconsistency and low transparency were contributing to great uncertainty in the business environment in Vietnam. Law enforcement was not consistent and uniform in the country and law interpretation and enforcement depended too much on local agencies or lower ranking state officials.

The external and internal stressors were reflected in the most important Party's documents in the early years of the new century. According to the Social-Economic Development Plan - adopted by the Ninth National Congress of the Communist Party of Vietnam (April 2001), Vietnam wanted to invest US\$ 60 billion over the period from 2000 to 2005 in order to sustain an average growth rate of GDP by $7.5 \%$ per annum (Communist Party of Vietnam, 2001). FDI was expected to contribute US\$ 12 billion to the implemented investment. With an implemented rate of $40 \%$, this meant Vietnam had to attract US\$30-35 billion of registered FDI during the period 20002005 (Le D. D., 2002). This goal would only be achieved if Vietnam could deepen the reforms, improve its investment climate, build trust of foreign investors and thus compete with other regional economies. In addition, foreign direct investment while better than during the years after the Asian Financial Crisis (from 1997-2001) remained below levels found in the mid-1990s (Nguyen H. T., 2007). 
The Party's Special Resolution No 7 on International Economic Integration issued on November 27, 2001 was another critical guiding document. The resolution revealed the pressures on Vietnam to push for continuous and deeper economic integration into the world economy. It asserted that "our business environment has been significantly improved, however still is being exposed to various weaknesses: disjointed and unsystematic legal framework, and lack of transparency" (Communist Party of Vietnam, 2001). The Party seemed to recognize that high economic growth could be maintained only by continued legal reforms and the existing institutions and policies in place were not enough. Without improvement in the policy framework, investments and capital formation would likely slow down (Dollar, 2002).

To summarize, this section has revealed the stressors on the government to take comprehensive legal reforms to establish an equal playing field for enterprises regardless their types of ownership. Although there were internal pressures to reform, the primary pressures were external and driven by Vietnam's desire to join the WTO. While stressors were at work, according to the policy change model proposed in Chapter III, the stressors by themselves do not guarantee an immediate radical policy change. Other policy factors need to be in place to ensure the final adoption of innovative policy. One of these factors proposed in the model is the predisposition of the CPV and its government to pursue reform. The role of this factor will be explored in the following section.

\section{Leadership predisposition to create an equal legal status for foreign}

\section{enterprises}

The Vietnamese Party and government had demonstrated its commitments to create a favorable environment for the foreign investors since the inception of Đổi 
Mới. In 1987, one year after the CPV decided to shift to the market-oriented economy at the VI National Party Congress, the Law on Foreign Direct Investment was promulgated. At that time, the Law was considered to be a very progressive document that would open a door for foreign investments and for international integration of the domestic economy. This law was then amended two times in 1990 and 1992 and then replaced by a new Law in 1996, responding to the perceived needs of investors (Le D. D., 2002). In 1996, the Five -year Socio-economic Development Plan 1996-2000 directly pointed to the intention to access the WTO and other international economic institutions as a strategy to achieve the goals of the plan. The momentum of reform had been slowed down from 1996 when there was a lack of consensus within the Party leadership on the pace of reform.

In the wake of increasing competition for foreign investment among the Asian countries after the Asian Financial Crisis in 1997, the Vietnamese government pushed for further reform to provide more incentives for foreign investors. The leadership predisposition to trade liberalization reform was intensified by the Resolution of the Fourth Plenum under the VIII National Party Congress 1997 in which the Party urged for a "proactive and positive attitude to penetrate and expand international market" and the need to "conduct quick and solid negotiation of the BTA with the U.S, and participate in APEC and WTO”. One year later, when Vietnam strongly felt the adverse impacts of the regional crisis, Resolution No.5-NQ/TW on the Socio-economic Missions of 1999 produced at the $6^{\text {th }}$ Plenum (first round) pointed to the need for developing integrative policy, institution, and procedure related to the investment environment and business conditions regarding enterprise establishment, land use, capital, technology, commodity flow, and tax (Communist Party of Vietnam, 1998). 
Following these resolution, in 1999, the Decision 53 (1999/QD-TTg) of the Prime

Minister reduced some service charges in order to limit the differences between domestic and foreign investors, which demonstrated the desire to advance towards a system with one common price for all (Tran G. X., 2000). In 2000, the Foreign Investment Law of 1996 was revised to give more rights of foreign investors, for example the rights to merge with and acquire companies and branches, and to transfer the form of investment.

In August 2001, the government of Vietnam adopted a Resolution on Indicative Measures to Promote Foreign Direct Investment in the period 2001-2005. The first priority of the government was a general overhauling of the legal system according to the international commitments that Vietnam had made in the framework of the Bilateral Vietnam-US Trade Agreement and AFTA (Le D. D., 2002). Also, Vietnam publicly expressed its desire to join the WTO by 2005, which required Vietnam to amend a large number of laws or legal regulations. Among these important changes was the development of the unified laws governing all types of enterprises and ownership forms (private, state-owned and foreign-invested enterprises).

In the same year of 2001, the special Resolution of the Politburo No. 07NQ/TW on International Economic Integration asserted that:

"The strategy of international economic integration has been confirmed clearly in various resolutions of the Party and in reality has been step by step implemented; however, the policy image in terms of the contents, phases, and pathways for international economic integration has not been supported by strong consensus. A segment of public officials had not recognized the opportunities as well as the challenges offered by proactive integration of the economy; the economic structure was changing slowly which was insufficient to exploit the relative 
advantages of the country. Many policies and mechanisms were slow to change in accordance with the requirement of international economic integration" (Communist Party of Vietnam, 2001).

Based on this acknowledgement, the resolution called for the creation of "an integrated economic management mechanism for a Socialist-oriented market economy, and the creation of a favorable and equal business environment for all economic sectors".

In keeping with the commitments of the CPV, the government released a number of incentives for foreign companies. For example, the corporate income tax was lowered in comparison with other countries in the region. Beginning in January 2004, the standard rate was $28 \%$ and the preferential rates for foreign investment in some areas ranged from $10 \%$ to $20 \%$ (Meyer, Tran, \& Nguyen, 2005). Foreign investors could be exempted from import duties on fixed assets, such as machinery, means of transport, and construction materials that were not produced locally. Further exemptions were made available for raw materials, spare parts, parts and materials imported for production of goods for export. Moreover, foreign investors were permitted to carry their losses forward for up to five years.

In summary, economic liberalization required major reforms in Vietnam's still highly restrictive regulatory framework, which hindered foreign investment prior to the passage of the Investment Law of 2005. The Vietnamese Party and government had shown the predisposition to initiate comprehensive legal reforms, especially after Vietnam decided to sign the Bilateral Trade Agreement with the U.S. The previous significant legal changes made in response to the Asian Financial Crisis, including the Enterprise Law (1999), the Law on Domestic Investment Promotion, the revised Law on Foreign Direct Investment (2000), and the Law on State-owned Enterprises (2003) 
was not innovative enough to create an equal legal status for enterprises among all economic sectors. Moreover, the existence of different kinds of laws regulating different types of enterprises and investments (public, private and foreign) revealed that there was still legal discrimination among enterprises operating in different economic sectors. In order to bring about the adoption of an integrative legal framework that would level the playing field for all kinds of enterprises regardless ownership, the Party and government had to change their policy image on the role of foreign-owned sector in the economic development of Vietnam. The following section examines the changes in policy image of the Vietnamese regime in relation to the foreign-owned sector.

\section{The significant change in policy image in foreign investment sector}

Even though Đổi Mới initiated a series of economic reforms, it was not the case from the beginning of Đổi Mới that the Vietnamese Party and government favored a free market that was non-discriminatory to foreign investment. For the beginning of the reform process initiated by Đổi Mới, the Party and government were afraid that the uncompetitive state-owned enterprises and new private enterprises would not be able to compete against foreign enterprises, especially multi-national corporations. In political terms, the legacy that the leadership carried from the Cold War was a fear of foreign interference, which in turn influenced the Vietnamese government's foreign policy. Many senior party members instinctively questioned the policy of engaging in too much interaction with the outside world (Pierre, 2000). They felt threatened by the emerging transnational forces and "soft power" of the twenty-first-century global system. Even after Vietnam decided to sign the BTA with U.S., the progressive Party's Resolution No. 07 in 2001 cautioned that "the 
integration plan and phase should be appropriate in relevance to the developmental level of the domestic economy while meeting the requirement of the international organizations" and "international economic integration needs to be aligned with the demand for security and national defense, ... [and] be alert for the plot of peaceful evolution" (Communist Party of Vietnam, 2001).

The fear of losing the control over the economy was the main reason for continuing with discriminatory policies and practices among various types of enterprises in the market economy. This fear is reflected in the three different kinds of laws that separately regulated the investment procedures of state-owned, private and foreign-owned enterprises (the Law on State-owned Enterprises of 2003, the Law on Domestic Investment Promotion of 1998, and the Law on Foreign Direct Investment of 2000, respectively). These laws had been gradually and incrementally revised to provide more specific legal frameworks for the investment of each type of enterprise. They narrowed the legal the differences between the economic sectors and created more favorable environments for private and foreign-invested firms, but they stopped short of putting all companies and sectors on an equal footing. For this to occur, the government would need to change its policy image strongly influenced the legacies of the state-led economy under the Soviet economic model. In the Soviet model, the state takes full control over the economy and considers private ownership a deviation from the proper economic management and political values. Under this model, international economic relationships with foreign countries risked the adverse impacts of global capitalism on less developed countries that could not compete successfully in the global capitalist economy (Nguyen D. L., 2010). 
However, with the deeper integration into the world economy and practical experiences of the process, the Vietnamese Party and government realized the significant roles of the non-state economic sectors and did not see a necessary conflict between the existence of both private and public economic systems in the economy. The increasingly important contribution of the private and FDI sectors to the economic growth and rising income gradually convinced the government to create an equal legal status for all types of enterprises. More important, a level playing field was considered a prerequisite for admission to the WTO, an important status goal of the Party that stood as a critical incentive to the economic arguments for membership.

The change in policy image was a gradual process that began in earnest with the signing of the BTA with the U.S. in 2000. In an interview of the same year, Trần Xuân Giá, Minister of Planning and Investment, publicly admitted the important role of foreign direct investment to the economic development of Vietnam. By that time, FDI was providing 28 percent of all investment in Vietnam, which constituted 10 percent of GDP, 32 percent of industrial production and 22 percent of exports (Tran G. X., 2000). In addition, FDI contributed U.S. $\$ 300$ million annually to the government budget and directly created employment for some 300,000 workers. As Mr. Giá stated, foreign investment in Vietnam had contributed to the development of new industries, for example, automobile manufacturing, oil and gas exploration, telecommunications, hotels, and tourism. It also produced some goods that can replace imported products, for example, steel and cement. In short, foreign investment had brought new modern technology and advanced management skills into Vietnam, thus demonstrating that foreign investment not only had financial benefits, but more 
importantly contributed to the long-term social and economic development of the Vietnam.

The decision to sign the U.S.-Vietnam trade agreement after a year of hesitation consolidated the predisposition of Vietnam to engage more fully in the global economy (Pierre, 2000). However, it took about five more years before the Vietnamese leaders changed their policy images and accepted the radical policy decision to remove all forms of legal discrimination among the foreign-owned enterprises and their domestic counterparts. While the change was significantly aided by the BTA agreement with the U.S., the actual experience of implementing this agreement provided additional incentive to the Party and government leaders. FDI and industrial growth resulting from the BTA continued to increase at a high growth rate. Garments exports experienced a particularly high rate of growth, contributing over $50 \%$ of Vietnam's exports to the USA in value, with further growth expected with Vietnam's anticipated membership in the WTO (Ministry of Trade of Vietnam, 2004).

In addition to the importance that FDI played in changing the policy image of the Party and government leaders, the changing perspective on the role of the private sector in Vietnam's economy also contributed to the change in the policy image. There was significant growth of the private sector in Vietnam, especially after the Enterprise Law in 1999 was promulgated. This law was a significant step to create an equal business environment for all types of domestic enterprises by streamlining and providing a uniform process for domestic business registration. Especially, in 2002, a special Resolution No. 14 at the Fifth Plenum of the Party Central Committee on Private Economic Sector strongly called for changes that would create a more favorable environment and set of conditions for private economic development. This 
resolution recognized that the private economic sector was an important component of the national economy. Private economic development was viewed by the Party as part of a "long-term strategy under the development of a multi-sectorial Socialist-oriented economy, contributing to the success of the key missions of the industrialization and modernization cause and increasing domestic strengths during the international integration process" (Communist Party of Vietnam, 2002). Acknowledging the role of private the sector, the resolution called for the "revision and supplementation of the Enterprise Law and other existing legal frameworks in order to eliminate discrimination among economic sectors ensured by an integrative policy on private economic development of the Party and government".

To summarize, in order to sustain a high rate of economic growth and to meet the requirements of the international economic integration, the Party and government leaders gradually reached consensus that the legal framework of Vietnam needed to be fundamentally altered. However, the decision to streamline the regulatory framework by creating a level playing field for both foreign and domestic companies in all sectors of the economy took place only after there were changes in the policy image of the Vietnamese Party and government. The change in policy image was encouraged by the initial positive economic performance in the wake of the BTA with U.S. And it was then reinforced by the considerations that would come from becoming a full-fledged member of the global economy by acceptance into the WTO. In addition, even though the CPV and government still considered state-owned enterprises as the cornerstone of the economy, they came to believe that private companies and non-state owned foreign companies were important to the success of Vietnam's economic, social and political development. 
While a change in policy image is treated by the policy change model in Chapter III as a necessary precursor to major policy change, a change in policy image does not make such change inevitable. This is because the model also considers the importance of a final factor in the policy change process of Vietnam, namely the Party's consensus on political priority at given point of time. This is an issue I will explore in the next part of this section.

\section{Political priority of CPV in the first years of the $21^{\text {st }}$ century}

Vietnam entered the new millenium at a time that was adversely impacted by the Asian Finanical Crisis in 1997. A decade after Đổi Mới in 1986, Vietnam experienced remarkable socio-economic achievements. However, the Asian Financial Crisis and Vietnam's slow pace of change in its legal framework risked the initial achievements of Đổi Mới. The Political Report of the Party National Congress in April 2001 (IX Congress) focused on a variety of major challenges to the country. These included distraction from the socialist pathway, corruption, bureaucratic inefficiency, and the risk of being left behind economically among other developing countries (Communist Party of Vietnam, 2001). Being left behind economicaly was listed by the Party report as the greatest of all challenges. The report called for the acceleration of industrialization and modernization, building an independent economy to make Vietnam an industrialized country, and giving priority to the development of the force of production. It asserted that "every economic sector is an important component of the Socialist-oriented market economy, which cooperate and compete with each other in the long run" (Communist Party of Vietnam, 2001) .

The Political Report, along with the subsequent Socio-economic Strategies of the period 2001-2010, emphasized the goal of "taking the country out of the less- 
developed situation, increasing people's spiritual and material lives, creating the foundation for the country to become an industrialized country by 2020" (Communist Party of Vietnam, 2001). The report called for a GDP growth rate by 2010 that was twice the level of 2000 with an economic structure which would rapidly reduce the share of labor in agriculture below 50\%. In five years from 2001 to 2005, the GDP growth rate was expected to be $7.5 \%$ annually on average. In order to reach these goals, the report recognized the need to build a multi-sectoral economy in which each sector is an integrative component of the entire economy. The special Resolution No. 7 in 2001 of the CPV on International Economic Integration is a further step to specify the demand for international economic integration into the world ecomomy, urging "proactive integration in order to stimulate domestic strengths and effectiveness of international cooperation".

To summarize, the first priority of the CPV and goverment in the period from 2001-2005 was economic development and international economic integration. The regime was pressed to succeed in achieving the industrialization and mordernization goals which had been damaged by the Asian Financial Crisis at the end of 1990s. Accordingly, the Party and government leaders realized that these goals could not be achieved without comprehensive reforms in Vietnam's economic legal framework. These reforms would necessitate removing legal barriers between private and state owned enterprises and between domestic and foreign owned enterprises. Accomplishing these changes became the top political priority of both CPV and government leaders. As the result, many innovative legal changes were adopted by the Vietnamese government on the threshold of the accession to the WTO. 


\section{Conclusion on the relevance of the policy change model to the case}

The proposed major policy change model presented in Chapter III is useful in explaining the policy change process in the economic legal framework regulating foreign direct investment in Vietnam. It helps to elucidate why in the midst of positive economic performance in the years of 2004-2005, the Vietnamese government accepted various radical changes, especially the issuance of the Investment Law, which set the level playing field for various kinds of enterprises, regardless of ownership. Even though the government still considered state-owned enterprise sector as the backbone of the regime economic power, the will to fully integrate into the world market dominated the fear of adverse consequences to the state sector. Through the passage of the integrative Investment Law, Vietnam demonstrated the significant change in the mindset of the regime that recognizes the equal status of private and foreign-owned with the status of the state-owned counterparts.

By employing the stressor concept, we can see that the application to the WTO and the obligations under various international agreements, particularly the BTA with the U.S., were the main sources of pressures on Vietnam for comprehensive reforms. In this case, the stressors did not come from negative economic performances. Rather, they arose from the pressure created by the changes in international trade liberalization, a different policy arena than the arena of domestic legal reform. At the threshold of the official admission to the WTO, the National Assembly was rushing for completing all of the legal changes to successfully guarantee its admission to the WTO.

The concept of leadership predisposition to reform is also helpful in examining the actual intention and acceptance of the CPV and government to put in 
place a new integrative legal framework governing various kinds of enterprises operating in the different economic sectors. By looking at Party resolutions and socio-economic plans, we can see that by the time Vietnam signed the BTA with U.S, the Vietnamese regime had strongly and clearly shown its willingness to pursue further and more comprehensive legal reforms to set equal and favorable conditions for foreign-owned enterprises. Guided by the leadership predisposition of the Party, the Vietnamese government and National Assembly had advanced the issues of comprehensive legal reforms in providing equal legal status for enterprises of all economic sectors in the their agendas. The special Resolution of the Politburo on Private Economic Sector in 2002 was a critical guiding document that demonstrated the Party's recognition of the significant role of the private sector in the economic development of the country and the need to create a non-discrimination investment environment for the non-public sectors. Even though the resolutions focused on the domestic private sector, it had important implications for the foreign-directed sector.

Despite the clear path that had been established since 2001, it took another four years for Party leaders and government officials to gradually change their policy images with respect to the equal roles of public and private enterprise sectors operating in the economy. Creating a level playing field means less privileges or priorities to domestic and especially state-owned enterprises. It also means that there will be more risks for domestic firms when they have to compete directly on an equal footing with their foreign rivals. From a political perspective, removal of all barriers for foreign investment in the domestic economy means that the state does not have as much control over the political and economic development of the country. Extreme openness of the economy might cause the collapses of domestic institutions such as 
the public universities, which in turn could risk social stability and party control. Here, it should be noted that, due the lack of information and data, this case is not able to shed light on these kinds of considerations. Access to this information would provide a more complete understanding of the process of changing policy images that occurred in the years preceding the adoption of the Investment Law in 2005.

The concept of political priority of the CPV is helpful in explaining why Vietnam committed itself to the most comprehensive reform agenda since Đổi Mới. Indeed, from 2000-2005, the resolutions, strategies and agendas of the CPV and government demonstrated that economic and trade reforms were the main focus of their attention. The regime had gradually felt the serious impacts of the Asian Financial Crisis on the flow of FDI and on exports. Party and government leaders were well aware of the wave of legal reforms that were taking place in most of the countries in the region. In the wake of the regional crisis in 1997, the Party risked serious long-term declines in growth if it failed to follow its neighbors in undertaking widespread legal reforms. Thus, even though the legacy of Socialism still remained, the highest priority of the CPV in the first years of the new century was economic development. Party and government leaders believed that high economic growth might help Vietnam increase its GDP per capital rapidly which in turn would ensure higher living standards for the people. Moreover, the priority for economic growth was supported by the positive results of the BTA with the U.S and sound economic performance starting from 2002. At that time, the regime did not see a strong conflict between economic openness, social stability and party leadership. Thus the significant changes in the policy image on foreign investment along with Party's first priority given to economic reform helped produce a large number of new laws in various 
sectors that make many to consider the series of legal reforms and policy changes in 2005 as the second phase of Đổi Mới. 


\section{Chapter IX: Conclusion}

This last chapter will summarize the overall conclusions of my case study analysis and outline some directions for future research. The chapter is divided into three sections. The first section discusses the relevance and explanatory capacity of the major policy change model that I have proposed in Chapter III. The second section discusses the contributions of my study to the policy process literature and policy reform studies in Vietnam. The final section of this chapter discusses the limitations of this research study and implications for future lines of inquiry.

\section{The relevance and explanatory capacity of the proposed major policy} change model

This chapter will not repeat the summary contributions of each case to the validation of the four policy change factors that are part of my policy change model proposed in Chapter III. Instead, I will discuss cross-case comparisons and examine the cases as a whole to tell us about the relevance of the four policy change factors and the logical flow of the proposed policy model. In the first part of my discussion, I will focus on the way in which the role of a policy change factors might vary across policy domains. In the second part of this section I will explore the causal flow among the four policy factors in the policy model. In the final section, I will examine the overall implications of this study for the understanding of the key elements of the policy-making process in Vietnam.

\section{The role of four policy factors in the policy change process in Vietnam}

In this section, I will draw from the four case studies to provide a summary discussion of the importance of each of the four policy change factors that are part of my proposed major policy change model for Vietnam. 


\section{Stressor}

As explained in the proposed policy change model, stressors are considered independent variables at the first stage of the policy process. Stressors to a policy subsystem may include: natural and human disasters, economic crises, structural changes in socio-economic conditions, critical changes in other policy areas, national mood, or international pressures. Adverse consequences may occur if the stressor is not addressed. Stressors serve as the catalysts that make major policy change more likely to happen by disclosing new knowledge, new risks and new challenges. Thus, by underscoring anomalies in the prevailing policy paradigm, or raising the visibility of new problems, stressors can provide opportunities for policy learning within the policy subsystem which in turn can trigger changes in the policy maker's perception of the problems, how they rank values or priorities, and how decisive they are in pushing for major policy change. As a result, stressors trigger a new policy cycle in which policy change initiatives are considered by public agencies and policy elites.

In all four cases there existed strong stressors that pushed for new policy change initiatives to be undertaken by the regime of Vietnam. While stressors were present in each of the four cases, the stressors in each case were different in the form and level of visibility. For instance, in the higher education case, the Vietnamese Communist Party and government were pressured by both internal and external critics to undertake major educational reform in order to create a workforce that could successfully compete in a globalized economy and provide a higher standard of living for the citizens. Reports produced by the Consultative Group Meeting in Vietnam, McKinsey Global Institute, and the Economic Committee of the National Assembly revealed a low productivity level of the Vietnamese workforce. Two well-known 
reports by Harvard Kennedy School of Government on the Vietnamese higher education system in 2008 and 2010 even used the word "crisis" to describe the status of the system. Starting in 2005, the CPV, National Assembly, Prime Minister and Ministry of Education and Training repeatedly recognized that low quality of education was challenging the quality of economic growth in Vietnam and the attractiveness of the business environment. There were numerous reports, directives, decisions, and other legal responses that recognized the need to make change, particularly in providing higher education institutions with greater autonomy. As late as 2012, the Party and government recognized the need to change, which was reflected in passage of the Higher Education Law of 2012 and the agenda of the $6^{\text {th }}$ Plenum of the Party Central Committee just finished on October 15, 2012.

However, in contrast to pressures to make changes on the economic front, there has been little tangible pressure to change in higher education policy. There are several factors that explain this result. Unlike the pressure for economic change, the stressors in the higher education sector are much less quantifiable and visible. The quality of the labor market in Vietnam and in most of other countries does not show up directly low quality of higher education as the primary cause for a poor economic growth and development. The weak connections between the business sector and higher education institutions in Vietnam make the stressors less viable. In addition to the issue of whether stressors are felt and seen, as elaborated in my proposed policy change model, there may be a variety of reasons why the stressors are not acted upon, such as the predisposition of the party leaders to reform; significant change in the policy image, and the consensus of Party on political priorities which favor the policy change initiative. 
In contrast to the case of higher education, in the case of international trade liberalization, the stressors were much clearer and more measurable. Stressors are represented by quantifiable economic performance and indicators caused by the Asian Financial Crisis in 1997. For example, Vietnam's GDP growth sharply declined from $9.54 \%$ in 1995 and $9.43 \%$ in 1996 to $5.76 \%$ in 1998 and $4.77 \%$ in 1999 (Nguyen H. T., 2007). The registered foreign direct investment fell dramatically from 8.7 billion USD in 1996 to 1.6 billion USD in 1999. In addition to internal economic situation, external factors also placed pressures on the Vietnamese Party and government to make radical policy changes. For instance, after the Asian Financial crisis, many countries in the region depreciated their currencies in order to make their products cheaper (which also means more competitive) than the same kind of products produced in Vietnam. They also implemented various reforms in the banking system and legal framework that made their business environments more attractive than Vietnam. These pressures were especially strong from Vietnam's giant neighbor country - China. China signed the BTA with the U.S. in November 1999 and expressed their desire to become a member of the WTO by 2001. These actions made the products from China much more competitive than those produced in Vietnam because of the lower import tax applied in by the U.S. and other countries. All of these internal and external factors put strong pressures on Vietnam's existing policy on international trade. As a result of the policy changes being made by other countries, Vietnam was under strong pressure to reach the consensus on most of the technical issues of the BTA with the U.S. by the end of 1999.

While significant stressors with respect to trade liberalization resulted in major policy changes, this has not been the case with state owned enterprises. From the very 
beginning of the Do Moi Program in 1986; the Vietnamese Communist Party and government have felt the pressure to reform the state economic sector. The pressure increased when Vietnam signed the BTA with the U.S. in 2001, joined WTO since 2006 and especially after the bankruptcy of the Vinashin Group in 2010. At each point in time, the stressors pressed the Party and government to produce guiding documents for improving the efficiency of state-owned and operated enterprises. Indeed, in 1995, only several years after Vietnam allowed the establishment and operation of private and foreign-invested enterprises, these two non-state economic sectors had growth rapidly to contribute to $28 \%$ and $30 \%$ of the total investment respectively and to $25 \%$ each of the total industrial outputs (General Statistic Office of Vietnam, cited in Muller, 2005). The rapid growth of non-public sector enterprises put pressure on the government to restructure state economic enterprises so that they could compete more successfully with the other sectors. As a result, the Law on State-owned Enterprises was passed in 1995 to replace the previous rule-by-decree practice with the hope of increasing the efficiency and performance of the state owned and operated sector.

The pressure on the state economic sector had grown after the Asian Financial Crisis in 1997; especially after Vietnam signed the BTA with the U.S. State-owned enterprises became exposed to fierce direct competition from multinational companies in the U.S. and other developed countries. The more Vietnam liberalized international trade and foreign investment, the more the state-owned enterprises experienced competitive pressure. In 2003, when Vietnam accelerated the negotiations with the WTO, the Law on State-owned Enterprises was revised to establish a more marketbased and disciplined legal framework for the state economic sector. The Vietnamese 
government anticipated the demand for renovation in the state economic sector in order to better cope with international rivals when Vietnam was expected to joined the WTO in 2006.

From 2008 to the present, the stressors to SOEs have changed in nature. Indeed, before 2007 when Vietnam joined the WTO, the stressors came from the competition that domestic private and foreign economic enterprises gave to the $\mathrm{SOE}$ sector within the national economy. As a socialist state, the CPV and its Government wanted to retain a strong state economic sector to provide the state with the economic resources and the political power that the regime needed to achieve non-economic goals. For example, the Party and government were committed to principles of equality among the various social classes; they were committed to affordable price of basic commodities. The prices of basic commodities are in turn depending on how the government monitors the key state economic groups who control the capacity of setting the prices. These noneconomic goals meant that the Party and government needed to place higher priority on political control and centralized party leadership.

However, the bankruptcy of the Vinashin Group, the disclosure of huge debts and economic loses by SEGs and SGCs pushed the CPV and government to rethink its views on the role of SOEs within the economy and what was needed as a strategy to build a strong and large state economic sector. A combination of factors, including scandals and poor performance of SOEs, economic recession, growing inflation rates and huge loses of state budgets, caused the regime to reconsider the issue of stateownership and the meaning of being a Socialist regime. In the midst of these increased pressure, a number of leaders of SEGs and senior public officials were singled out for investigation for corruption, which ultimately resulted in the arrest of 
some SOE leaders. The management failures of SOE continued to be the focuses of the Party, and were one of the three main focuses of the recent $6^{\text {th }}$ Plenum of the Central Party Committee in October 2012.

In the case of legal reform to establish a level playing field for enterprises of all economic sectors in 2005 , the government had to adopt a number of radical legal changes in response to stressors from the desire to integrate deeper into the world market especially from the WTO accession. Unlike the other cases, the stressors in this case were more external in nature. As has been discussed in Chapter VII, most of the socio-economic indicators of Vietnam in 2004 and especially in 2005 were very positive. GDP growth peaked at the rate of $8.4 \%$, which was near the level prior to the Asian Financial Crisis in 1997 (9.34\% in 1996). The GDP per capita increased more than four times, from US\$146 in 1990 to US\$630 in 2005; the total value of exports has increased to US $\$ 36.5$ billion in 2005 , reaching an annual compound growth rate of 21.6 percent; and the poverty rate had declined substantially from 58 percent in 1993 to 19.5 percent in 2004. Despite the fact that Vietnam was enjoying strong recovery in the period 2002-2005, Vietnam was pressed to take radical legal reforms as a condition of being admitted to the WTO. The stressors were intensified by different events, starting from the Asian Financial Crisis in 1997, then the BTA with the U.S in 2001 and finally the admission to WTO in 2006. At the threshold of WTO accession, the pressures to accept the various abiding rules and comprehensive legal reforms forced the Vietnamese government to hastily adopt a number of legal reforms in 2005. Thus, in this case, the stressors for innovative policy changes arose from the radical change in other policy area, namely international trade. 
To summarize, in all of the cases under study in this dissertation, the empirical evidence proved the presence of stressors to the policy subsystems. However, the level of visibility and intensity was different. Stressors might come from internal forces or from the external environment contexts or might arise from an economic crisis or from radical changes in the socio-economic conditions, or from the radical changes in other policy subsystems. While there is variability in the source of the stressors and their interface with other factors, the four cases support the broad conceptualization of the key role of "stressors" in the proposed policy model in Chapter III. The case studies together negate a narrow assumption of some theories dealing with policy reforms and politics in Vietnam that radical change can only be caused by internal pressures because the Vietnamese government has been able to control external conditions and has been insulated from international pressures (see views of Painter, 2003). In fact, once Vietnam expressed the desire to integrate more completely into the world community, gradually external stressors became much more important than in the past.

\section{Leadership predisposition to reform}

In the policy model proposed in this dissertation, the concept of leadership predisposition was defined as a psychological readiness of the policy elites to consider policy change initiative. This readiness is achieved only after the policy elites take into account the existing stressors along with the ideological commitments and political risks. Thus, the predisposition demonstrates the intention to reform a given policy area in response to stressors. It reflects how the policy elites perceive and articulate particular policy issues, how they assess the proposed change initiatives, and how they weigh political and technical factors in dealing with policy problems. 
The policy change model argues that once there is a predisposition to reform within the leadership of the CPV, the given policy problems and issues will be officially advanced into the agenda of the National Assembly or government for further deliberation and study. This increases the possibility, but does not guarantee that a policy reform will be adopted.

Leadership predisposition is an abstract concept. However, in the case of a single-party and centralized political system like Vietnam, it is possible to identify this predisposition through the policy arguments of policy elites or policy statements in the Party's documents. As a Party-led system, when the Party affirms the need to act on a policy problem, it will be documented in the Party's guiding documents and be implemented by public agencies under the National Assembly or Central Government. Normally, policy stressors are initially documented at the ministerial level or by a committee of the National Assembly. A certain number of urgent issues will then be selected by the Government/Prime Minister or National Assembly to submit to the Party Central Committee led by the Politburo for guidelines - "chủ trương”. If the policy issues are considered by the Party to require new policy response, it will be affirmed by the Party and then passed on to the National Assembly or government for further actions. If not, the initiative will be delayed or ignored. It should be noted that even when the Party has agreed to consider changes in a given policy arena, it is a common practice to refer the issue for further deliberation and studies. In doing so, this approval for further study does not mean that the Party will automatically approve the final policy alternatives or proposals produced by the National Assembly or government afterward. Thus, the predisposition to reform is only the preliminary perception on the need to undertake policy reform. It does not mean that reform will 
actually be agreed upon. This is because the Party follows a process that involves different type of public organizations, including National Assembly's committees, Central Government's Office, ministerial agencies, and research institutions, even international advisors or consultative groups. After the policy change alternatives have been formulated, deliberated and selected by the state apparatus, the Party will be in the position to accept, delay or reject the policy change proposal.

In the four case studies, the CPV and government of Vietnam did show a predisposition to reform in each of the four cases. However, the leadership predisposition differed among the cases in terms of the level of intensity and clarity. In addition, the lag time between the time when the Party's expressed desire to undertake reform and the time the policy issues were advanced to the agenda of the National Assembly or government varied widely from once case to another. For example, in the case of trade reform, the BTA with the U.S was advanced into the government's agenda right away after the Party produced a guiding resolution in 1997. Whereas, in the case of higher education, although the Prime Minister Resolution No 14 on Comprehensive Renovation in Higher Education indicated a strong intention by the government to make radical change in this area for quality improvement, it took five years before the issue of higher education management policy was advanced to the legal agenda of the Ministry of Education and Training and then to the National Assembly in 2010. It then took two more years for the Higher Education Law to be ratified in June 2012.

In the case of higher education, the Party Central Committee of Vietnam issued a special resolution on education in 2009 that expressed the need for educational policy change, including higher education change. As late as October 
2012 the issue of education reform was listed as one of the top three priorities by the 6th Plenum under the XI Party National Congress. Notably, there has been a National Assembly's resolution in 2009 and a Prime Minister's directive in 2010 that directly targeted the need for higher education reforms, but there has been no specific resolution on higher education at the Party level. Moreover, even when the guiding documents in education produced by the Party, the government and the National Assembly pointed to the need for reform in the state management of higher education, the focus has been broadly expressed to include financial mechanism, curriculum renovation, teacher quality improvement, educational network, institutional autonomy, etc. Among the solutions to improve state management in higher education, increased institutional autonomy has not been considered as a high priority. To conclude, higher education is the case that witnessed the least predisposition by the Party leaders to undertake policy reforms that would give more autonomy to universities and colleges despite the fact that this issue has been repeatedly cited as important in many recent state documents. This explains why higher education reforms have been mostly limited compared to the policy changes in other cases (see the analysis of the Higher Education Law of 2012 in the Appendix for more details).

In the case of trade liberalization reform, the leadership predisposition to change was the most strongly present factor among the four cases presented in this study. Since 1995, Vietnam's political leaders had expressed a desire to undertake comprehensive trade liberalization through their decision to join AFTA, initiating negotiations to join the WTO and starting the BTA negotiation with the U.S. In 1996, the Five-year Socio-economic Development Plan 1996-2000 directly pointed to the Party leaders' intention to become members of the WTO and other international 
economic institutions, although the document did not mention specifically a BTA with the U.S. Only after the occurrence of the Asian Financial Crisis in 1997 did the predisposition to advance trade liberalization reform intensify, especially with the Resolution No 7 of the Fourth Plenum under the VIII National Party Congress. In the solution section of this resolution, the CPV called for a "proactive and positive attitude to penetrate and expand international market" and the need to "conduct quick and solid negotiation for BTA with the U.S., and participate in APEC and WTO”. Nonetheless, the BTA with the U.S was a sensitive and controversial issue that was the source of contentious deliberation within the highest organs of Party and government about the pace and scope of international economic integration. Eventually, in 2000 the BTA was signed but it took one more year for the regime to wholeheartedly accept agreement after the CPV released the Resolution No 7 on International Economic Integration in November 2001.

In the case of state-owned enterprise management policy, from the inception of Đổi Mới the CPV has demonstrated the intention to improve the efficiency and competitiveness of the state economic sector. As I have presented in Chapter VII, in all of the Party's resolutions and five-year socio-economic development plans since the early of 1990s, restructuring and reshuffling SOEs has been the primary concern and focus of the political leaders. Especially, the Resolution of the Third Plenum of the Party Central Committee of the IX National Party Congress regarding reorganization, reform, and development of the SOEs (2001) and the Resolutions No 28-NQ/TW of the Politburo on Reshuffling, Reforming and Developing State Farms and Forestry Firms (2003) pointed directly to the issues related to state management in SOE sector. These documents provided guidelines for reforms in this sector as means of achieving a 
deeper integration of Vietnam's economy into the international global market. In 2010 after the breakout of Vinashin's bankruptcy and negative performance of SEGs and SGCs, the Politburo produced a special Conclusion No 78 - KL/TW, which reemphasized the intent of the Party to reform this sector. This intention had been already articulated in a resolution of the Party nine years before (the Resolution of the Third Plenum at the IX Party Congress). Most recently, in the face of tremendous criticism from the public and international organizations for the failures of the SEG and SGC model and very serious debts and large economic losses by the SOEs over the past few years, the Party once again identified state economic sector reform as one of the three urgent issues of the 6th Plenum under the XI Party Congress in October, 2012.

In short, the leadership predisposition to reform the SOE sector has been well articulated in the Party's guiding documents. As a result, a large number of laws, decrees, and directives have been produced in response to the Party's call. Notably, the predisposition to reform SOEs before 2008 focused more on increasing the competitiveness of the state economic sector when Vietnam integrated deeper into the world market. After 2008, in the face of SOEs large-scale failures, the predisposition to reform changed dramatically with an increased focus on the question of the right ownership model, the nature of the relationships between the state and SOEs and the role of SOEs in the market-oriented economy. However, the lack of a significant change in the policy image resulted in no real serious and innovative change being made during the period of this study.

The last case of legal change in foreign investment shows the greatest leadership predisposition to reform. After the BTA with U.S. was signed in July 2000 
and then ratified in 2001, the CPV was able to reach consensus and stood firm on its intention to fully integrate into the international economic institutions. The special Party Resolution No. 7 on International Economic Integration in 2001 marked a point in time when the Party considered further and comprehensive domestic legal reforms as an irreversible necessity in order to be accepted into the WTO. With this strong predisposition to legal reform, the National Assembly, government and various ministerial agencies accelerated the law-making process in every sector to revise, integrate and replace laws and regulations in the period 2002-2005. The main goal was to meet the preconditions for the accession to the WTO and to create a more favorable business environment for investment and trade. Here, it should be noted that the leadership predisposition was intensified by additional stressors as time went by. For example, the Asian Financial Crisis in 1997 consolidated the will of the CPV to reform the legal framework in order to attract more foreign investment and to meet the requirements of bilateral and multi-lateral trade agreements. Then predisposition to reform were intensified at the threshold of WTO accession which forced the government to accept broad-based and comprehensive reforms to establish a level playing field for enterprises in all economic sectors in 2005.

To summarize, while stressors are a precondition for major policy change in Vietnam, these stressors do not result in the advancement of policy change initiatives without another precondition: the predisposition of leaders to initiate policy change. However, this precondition can be present and still not result in any major policy change. For example, stressors and a predisposition to change were present in all four cases in this study. However, in only two cases did any major change actually occur. Studies of these cases where major change did occur indicate that other important 
factors were present, including a change in the policy image of party leaders and a high consensus on the political priority of making the given changes compared to other potentially competing political priorities of the CPV at given points of time.

\section{Policy image}

In the proposed major policy model for Vietnam, the concept of "policy image" was defined as the belief through which the policy actors: (1) interpret a given set of policy issues, (2) identify the causal relationships between these issues and the existing policy or the absence of relevant policy, and (3) rationalize their solutions resolving the issues. Policy image also reflects the assumptions on the best way to realize the core values and political priorities of the Vietnamese regime. In Vietnam, to maintain these values and priorities, the regime needs to achieve intermediate goals such as high economic growth, improvement in the people's living standards; social equality, and social welfare system for the mass, etc.,. In the proposed policy model, significant change in the policy image of the CPV and government is critical for the formulation of innovative policy change alternatives to address the core problems in the transitional process of development. After formulated, the policy change alternatives will be selected if it is perceived as the instruments to contribute to the intermediate goals while not directly risks the core values of principles of the CPV. This in turn will determines if such alternatives are considered "technically feasible" and then to be advanced to the final stage of adoption.

In the four case studies of this dissertation, the policy image was significantly changed in the two cases that witnessed the most radical changes while the policy image remained unchanged in the two cases that did not experience any significant policy change. In the case of trade reform, a change in policy image was clearly and 
dramatically documented. During the negotiation process of the VNUSBTA, the two sides gradually built trust in one another by breaking down pre-existing stereotypes and obsessions with the past war. The current national interests came into increasing play for the Vietnamese delegation, replacing their preoccupation with the past. By looking to the future and the positive feedback from the trade agreements between China and other countries with the U.S, Vietnam anticipated the positive outcomes of the BTA to its economy rather than the adverse impacts of further trade liberalization. Vietnam came to understand that the BTA would bring in mutual benefits for both sides and without the BTA with the U.S, Vietnam could not integrate deeper into the world economy in general and join the WTO in particular. The change in the policy image on the BTA with U.S resulted from a prolonged process of negotiation and exchanges with the U.S. delegation, from internal debates and deliberation within the leadership groups of the Party and government, and also from self-education with new information, feedback and evidence made available by technical analytic policy actors.

What is most interesting about Vietnam's policy changes in the area of international trade is that arguments based on technical assessment and feasibility were necessary, but they were not sufficient to bring about major policy change. By 1999, all the technical issues had been resolved by the two negotiation delegations; however, the BTA was postponed for one more year due to lack of consensus within the highest organ of the CPV. As I have presented in Chapter VI, the General Secretary of the Party at that time was not able to reach a compromise among the conservatives and reformers in the Politburo. In addition, he was a leading figure of the conservative groups within the Party leadership organ who did not favor rapid and 
comprehensive economic reforms. As a result, only in 2000 when the reformers took over control of the Politburo and the General Secretary lost his leadership legitimacy that the final agreement was reached within the leadership of the Party to accept the BTA with U.S.

In the case of legal reform (Investment Law), radical change in the legal framework did not occur until there was a change in the policy image by Party leaders on the role of non-public economic enterprises in the economic development of Vietnam. Up until the end of the 1990s, there was still a fear that the forces of capitalism in the private economic sector would dominate the domestic economy of Vietnam and risk social coherence and the leadership of the CPV. Even the breakthrough Resolution No. 14 on International Economic Integration issued in November 11, 2001 pointed out that "the integration plan and phase should be appropriate in relevance to the developmental level of the domestic economy while meeting the requirement of the international organizations" and "international economic integration needs to be aligned with the demand for security and national defense, ... [and] be alert for the plot of peaceful evolution" (Communist Party of Vietnam, 2002).

However, this fear gradually diminished with the increasing contribution of enterprises in the non-state economic sectors. Private and foreign-invested enterprises significantly contributed to Vietnam's positive economic performance in the period after the Asian Financial Crisis, especially from 2001-2005. In addition, deeper and freer international economic integration, especially the BTA with the U.S., started to produce positive outcomes in terms of FDI and growing exports. As a result, the regime became much less fearful that a dynamic and strong private and FDI economic 
sectors would threaten political stability and Party leadership. Still, to maintain political control, the Party and government emphasized the need to develop the stateowned economic sector in key economic areas.

The change in the policy image on the role of the private sector, including the FDI enterprises, was reaffirmed by the special Resolution No. 14 of the Fifth Plenum of the Central Party Committee on Private Economic Sector in 2002. This document strongly urged the creation of a policy framework and incentives that would create a favorable environment for private economic development. The resolution pointed out that the "private economic sector is an important component of the national economy. Private economic development is a long-term strategy for the development of a multisectorial Socialist-oriented economy, contributing to the success of the key missions of the industrialization and modernization process and increase internal strengths in the international integration process" (Communist Party of Vietnam, 2002). The change in policy image on non-public sector enterprises, along with the increasing pressures from WTO on the requirements for comprehensive legal reform, pushed the National Assembly and government to accelerate the policy-making process of a large number of laws in 2005.

Unlike the two above cases, the two cases without radical policy are also the cases that did not see significant changes in the policy image of the Party and government. In the case of higher education policy, during the past two decades, Vietnam has come to attribute the weak and backward state management to the origin of the low quality of education in general and of higher education in particular. However, due to lack of policy image change with regard to the institutional autonomy of higher education institutions, the CPV and government have not 
produced an innovative legal framework to provide comprehensive institutional autonomy for universities and colleges. The lack of change in the policy image on the institutional autonomy in higher education has prohibited the formulation of innovative policy solutions dealing with the problems and stressors in this policy domain. As the result, the most updated Higher Education Law of 2012 which was expected to set a legal framework for innovative state management provides only abstract and conditional terms regarding the institutional autonomy for universities and colleges.

There are three main factors that have prohibited a significant change in the view of the regime with respect to higher education state management. First, according to the legacy of a Socialist state, higher education is an important area which helps maintain the core political ideology and values of the Party within the younger generations. In the economic area, higher education is supposed to provide the human resources for the industrialization and modernization process led by the state. Even though the top leaders of the government and MOET have repeatedly referred to the concept of "market-driven" higher education system in recent years, it does not mean that the regime want to release the system to the market rules. Instead, the state needs to direct the development process of this sector in consistent to the predetermined goals and demand set by the state for national development.

Second, the regime has been concerned about the adverse social consequences of granting comprehensive autonomy without having in place full-fledge accountability mechanism and enhanced administrative capacity on the part of higher education institutions. With the rapid growth in the newly-established universities and colleges, the political leaders have become more concerned about the quality of 
education and social responsibility of the institutions, especially in a market economy. The lack of trust in the administrative capacity of individual institutions has played a key role in stalling major policy change. The low quality of some private-owned or even public universities and mismanagement by leaders has diminished the effort of the Vietnamese government to release its ties on the higher education institutions. Third, until now, the government has not perceived a strong positive correlation between higher autonomy and better education quality. Unlike other western countries, administrative autonomy and academic freedom are not considered the backbone of the higher education system. The Party and government have repeatedly argued for state management reforms in higher education. However, the phase "state management - quản lý nhà nước" has been used with broad meaning to include financial management, teacher education, recruitment and compensation, university network, curriculum development and institutional autonomy. Until now renovation in the relationship between the state and higher education institution has not been considered as the first priority of state management reform and best solution for quality improvement in this sector.

Similar to higher education, the state-owned enterprises policy has not experienced any significant change, even though the need for change has been mentioned often in the Party and government documents. The existence of stressors to change and a recognition by the leaders of the need to change has not resulted in any policy reforms because there has been no change in the policy image in the role and function of SOEs held by Party and government of Vietnam. The Socialist legacy continues to view SOEs as the macroeconomic instruments and resources for the Party to control domestic and foreign economic forces. This view is congruent with 
Party doctrine that the social class that controls the means of production will be able to control politics and to lead the society. Given this view, SOEs are expected as important and effective macroeconomic instruments for state economic management as well as for the administration of the state welfare system. In addition, the regime has not seen a conflict between a strong state economic sector supported by the state and the development of the private and FDI sectors. The recent political and economic scandals related to SEGs have challenged the view that the state economic sector is an effective channel for the state to direct the industrialization process and to sustain Party's control over the economic forces. Nonetheless, the Vietnamese Party and government continue to stand firm on the will to develop a strong state economic sector by restructuring and reshuffling.

The word "restructuring-tái cơ cấu" has been repeatedly used by the policy elites in the way that does not include the release of state control on the economy or to transform the role of state to the marketplace. Instead, it is used to refer to the need to consolidate the state economic sector by making improvement in the ability of SOE'S to play a central role in the economy. Even though the Party and government have recognized the inefficiency and ineffectiveness of the SOEs, the lack of change in policy image have obstructed the formulation of innovative policy change alternatives in this sector over the past decades. As the result, the Party and government have fallen short of making any innovative policy change in this policy area and the major consensus within the Party and government until now is for incremental changes in the organization and management of the SOEs, instead of the change in the policy paradigm in this sector. 
To summarize, the concept of "policy image" is very helpful in explaining the divergent outcomes in the policy areas under review in this dissertation. Specifically, it helps explain why in the cases of higher education and state-owned enterprises, there has been no innovative policy changes over the past decades even though the CPV and its Government continuously emphasized the demand for reforms in these areas. The socialist policy legacy has impeded the significant change in the policy image in these two policy domains. As a result of the lack of significant change in the policy image, only incremental and modest changes have been adopted instead of radical and innovative policy change in state-owned enterprise and higher education sectors.

\section{Consensus on the political priorities}

In Vietnam, any major policy change alternative is ultimately assessed against two main principles: political stability and the absolute leadership role of the CPV over the state apparatus and the society. Because these principles are abstract, and can be interpreted in a broad sense, the Party's leaders have to refer to some intermediate or subsidiary political goals. For example, when examining the consequences of a particular policy change alternative, the Party can refer to social equality, economic development to achieve a higher living standard, social welfare for the masses, democratic-centralism, or the importance of state-led approach to development. At a given of time, the Party will consider the priorities among these goals and identify the most important to be achieved. If a policy change alternative is congruent with the dominant political priorities at the time, it will be adopted. The change in policy image is a critical to influence how the Party orders or prioritizes these goals and anticipates the impacts of the tentative policy change on the core values or principles. 
Thus, the differentiation between the political core values/principles and the intermediate political goals is very helpful in explaining the "pragmatism" approach of the CPV during the Đổi Mới.

Among the four case studies, the case of trade liberalization reform with the signing of the BTA with the U.S. is where the role of consensus on political core values and priorities is illuminated most clearly. The political judgment as the result of the lack of consensus within the Politburo did dominate the technical feasibility of the BTA. Indeed, by the middle of 1999 , most of the critical technical issues under the BTA were resolved by the two sides. However, Vietnam decided not to sign the agreement at the last minute and the BTA was postponed for nearly one year. At that time, the Politburo was sharply divided between the conservatives and reformers who disagreed about the pace of reform and the potential consequences of the BTA. The conservatives placed priority on democratic-centralism and social equality which argued for a slow and controllable integration process to avoid the risk of economic collapse and social chaos. By contrast, the reformers placed priority on economic development and higher living standards which argued for further policy reforms and deeper international integration. The lack of strong and decisive party leadership by the Party Secretary General resulted in a stalemate among the differing points of view of the members of the Politburo. The lack of party leadership consensus on what should be the chief political priority at that time delayed further economic reforms by each of the three plenums in 1999 despite serious economic recession. This explains why the Party delayed agreement on the BTA with the U.S even when all the technical issues of the BTA were resolved by the two negotiation delegations. 
In the case of legal reform in investment law, due to the change in the policy image of the Party regarding the role and contribution of the non-public sectors, the Party gradually overlooked the risks of legal reforms to economic development and social coherence. The Party became less cautious about creating unhealthy conflict between strong private and FDI sectors and a large state economic sector. Instead, the leaders recognized the important role of non-state enterprises in the economic development and prosperity of the country. In 2005, the change in the policy image was coupled with strong consensus within the Party on the priority of economic development in the period from 2000-2005, and the strong pressures from the WTO accession pushed the regime to adopt a bunch of legal reforms in many areas, some of which only constituted incremental changes in the past.

\section{The relevance of the causal flow of the policy change model in the cases}

Table 14 below summarizes the policy outcomes and the presence of the four policy factors that I have identified in the proposed major policy change model for Vietnam. In this section, I am going to discuss the extent to which the causal flow of change in the cases occurred in the causal sequence proposed by my policy change model.

Table 14: The relationships between policy factors and major policy outcomes in four cases

\begin{tabular}{|l|c|c|c|c|c|}
\hline $\begin{array}{l}\text { Cases/causal } \\
\text { factors }\end{array}$ & 1. Stressors & $\begin{array}{l}\text { 2. Predisposition } \\
\text { to reform }\end{array}$ & $\begin{array}{l}\text { 3. Change in } \\
\text { policy image }\end{array}$ & $\begin{array}{l}\text { 4. Consensus } \\
\text { of Party }\end{array}$ & $\begin{array}{l}\text { Major } \\
\text { policy } \\
\text { change }\end{array}$ \\
\hline Trade reform & Yes & Yes & Yes & Yes & Yes \\
\hline Legal reform & Yes & Yes & Yes & Yes & No \\
\hline $\begin{array}{l}\text { Higher } \\
\text { education }\end{array}$ & Yes & Yes & No & N/A & No \\
\hline $\begin{array}{l}\text { State-owned } \\
\text { enterprise }\end{array}$ & Yes & Yes & No & & \\
\hline
\end{tabular}


The major policy change model for Vietnam presented in Chapter III proposes a sequence of change that is depicted in the order listed in the first row of Table 14. First, the stressors arise due to the change in the internal or external circumstances. Stressors are documented by the state agencies and then reported to the government for review. At a given point in time, the Prime Minister can choose only a small number of stressors that are considered to be sufficiently important to justify considering major changes in policy. The government will report to the Party Central Committee (PCC) for leadership and guidance on how to respond to the stressors. At this level, the Party leaders will deliberate and determine whether they want to consider a policy change to address the stressors. If the Party perceives that there needs to be a significant change in a given policy area in order to respond to the existing problems, it will produce a resolution, conclusion or other kind of guiding document to direct the state agencies to further the discussion and study of the policy problems. As depicted in Figure 1, the predisposition to reform by the Party's leaders is the precondition for major policy change initiatives to be advanced to the official agenda of the National Assembly or the Central Government. After receiving the guideline from the PCC, the state agencies will lead the discussion, studies, and hearings in order to formulate and then to select the final policy change alternative.

At this stage, there must be a significant change in the policy image of the policy elites in order for them to be able to create an innovative policy change alternative. If the innovative policy change alternative is considered technically feasible, it will then be submitted again to the PCC of the CPV for final review. At this stage, the leaders of NA and government, who are also member of the PCC, will work with other members of the PCC and especially with members of the Politburo to 
discuss the political acceptability of the policy change alternative. The Party will take into account the political core values, especially the intermediate political goals when it examines the policy alternatives. If the Party can reach consensus on the priorities among the intermediate political goals, which favor the innovative policy change alternatives, then a radical policy will be adopted. Notably, the PCC convenes at least two times a year, each time for a week or two, to review the innovative policy change alternatives submitted by the National Assembly and the Central Government. The following section, I will review the policy change process in the cases to determine whether they confirm the sequential order proposed by the policy change model.

In general, all of the cases under review in this dissertation conform to the logical flow depicted in Table 12. However, there are important variations and subtleties in each of the cases that add the richness to the simple causal model. For example, in the first place, the trade reform case with the adoption of the BTA with U.S is the case that has proved the overall logics of the model to the largest extent. Similar to the case of legal reform in foreign investment, all the policy change factors identified in my proposed policy model were present and interacted with each other in consistent to the causal flow of the model to produce radical change. However, it differs from the case of legal reform in confirming the proposition No. 4 that the lack of consensus on political priority can impede the adoption of radical change. That is, the delay of the BTA with the U.S in the U.S demonstrates that political judgment can dominate technical feasibility.

The case of legal reform to set the equal play field for foreign-invested enterprises with the integrative Investment Law in 2005 followed the similar logical flow of the case on the BTA with the U.S with some divergences. First, both cases 
witnessed strong pressures from both internal and external stressors. However, in this case the pressures came from external stressors, namely the accession to WTO, instead the internal stressors of bad economic performance (affected by an economic crisis) in the case of trade reform. Also, the stressors in this case were not one time but were intensified to the end of the changing process. Second, the process of the policy image change in this case was not clearly isolated as the case of trade reform due to the lack of information about the internal debates within the state agencies on the Investment Law. Third, as presented in the previous paragraph, the Party consensus on political priority was not fully documented and explained clearly as in the case of trade reform.

In the two cases without radical policy change, the logical flow of the model was also affirmed. Overall, the lack of significant changes in the policy image of the Party and government in respective policy domains prohibited the adoption of innovative policy even though both cases witnessed strong pressures and predispositions for reforms. Indeed, over the past two decades, the Party and government of Vietnam have felt the stressors to reform higher education and stateowned enterprise sector in response to the problems and challenges. Notably, the stressors in the case of state economic sector have been more quantifiable and measurable while the stressors to higher education sector have been more abstracts and qualitative. In the face of stressors, the Party has shown leadership predisposition to reforms in both areas through many resolutions and conclusions of the PCC and Politburo. Interestingly, higher education and state-owned enterprise reforms were two of three urgent issues under the agenda of the $6^{\text {th }}$ Plenum of the PCC in October, 
2012. However, again, the results of this Plenum did not show any new policy image of the CPV in relation to state management in these two areas.

In both case, the lack of policy image change has prohibited the formulation and proposal of innovative policy change initiatives over the years. The lack of policy image change in both cases in turn is caused by the dominance of the legacy of the Socialist state with the Soviet model. In fact, Vietnam has been discussing and adopting a number of policy changes on these two policy areas. However, no innovative alternative has been advanced into the agenda of the state or revealed in a number of guiding documents. As a result, no innovative policy change has been adopted even the Higher Education Law was promulgated in June 2012 and the Plan on Restructuring the State-Owned Enterprises was approved in July 2012. It is very important to know that the regime has continued to consider higher education and state economic sectors as the key instruments for the state to maintain the core political principles. There has been a continuous fear that by losing these sectors, the regime will be put at risk in achieving industrialization and social development oriented by the Socialist characteristics.

\section{Policy implications to the policy process in Vietnam}

The major policy change model proposed in this dissertation, along with the evidence drawn from the four case studies, shed light on the policy process and policy outcomes during Đổi Mới in Vietnam. They help to explain why innovative and radical policy changes have been adopted in some areas while others only witnessed incremental and limited changes. Especially, the model and the cases studies elucidate some of the concepts like "gradualism", "pragmatism", "dual party-state system" that scholars have employed to describe the policy phenomenon and outcomes in Vietnam. 
In the following paragraph I am going to explain these concepts by referring to the proposed policy change model.

\section{Gradualism}

"Gradualism" has been used to describe a slow and controlled policy change process. The number and sequential order of the policy change factors listed in Table 12 explain why reform in Vietnam conforms to this gradualism model. In order for an innovative policy change initiative to be adopted by the Party and government of Vietnam, it must be able to get through different stages with different gatekeepers. This ensures that any innovative policy initiative that can bring in radical change is usually examined carefully through a variety of both technical and political filters. First, the existing political leaders must feel the real stressors and perceive the imperative for reforms in response to stressors. Then, there must be a predisposition to reform that goes beyond simply talk to the production of Party and government documents that provide a guiding framework for continuing the deliberative process of change. These documents legitimize the policy change initiative without guaranteeing that the initiative will be adopted later. It may take some time, even years or decades, for internal discussion and deliberation among the affected or concerned public agencies to change the inculcated policy image that has governed traditional thinking about a given policy issue. Education, additional information, intensified stressors may be required for the policy image change. After the consensus on the technical feasibility of the innovative policy initiative is reached, a second round of review is conducted in order to reach a common understanding and consensus on the political priority and its relation to the proposed major change. This stage involves a collective decision-making mechanism to achieve an accommodation 
of preferences and interests among the key members of the Party and government. At this stage of deliberation, participants bring in consideration on the risks of change to the Party's core political values and political priorities. As a result, the reform process in Vietnam is characterized by gradualism.

\section{Pragmatism}

"Pragmatism" refers to practical behaviors of the Vietnamese officials that are not always predictable based on abstract principles or ideology. As Shivakumar (1996) argued: "assertion that communism has been strongly biased against a market economy, with privileged policies, limited access to information, and so on, cannot therefore be seen as a characterization of the most powerful strategies at work in Vietnam, on socio-economic change". By employing the policy model and the analysis of the case studies, we can explain the pragmatic approach of Vietnam. Indeed, the ruling regime embraces two political core values serving as the guiding principles for the whole system: political stability and absolute Party's leadership over the state and society. To realize these core values, several intermediate political goals are advanced in practice. These goals can be social equality, social coherence, economic growth, higher living standards of the people, democratic-centralism, good governance, and party unity and strength. At different points of time, depending on the existing internal and external conditions, the CPV and its Government will deliberate to reach the consensus on the political priority among the above political goals. For example, in the case of trade reform presented in Chapter VI, at the time that the BTA with the U.S was ready to be sign, the consensus of the Party on social coherence and Party unity took priority over economic growth and governance reform. By contrast, during the period from 2000-2005, the Party reached consensus 
on giving top priority to economic growth and increased income and an improved standard of living. As a result of different priorities at different times, the BTA was not adopted in 1999 but it was adopted in 2000 .

\section{Dual party-state governance system}

The third concept that can be elucidated by the model and the case studies in this dissertation is the "dual party-state" political and policy system of Vietnam. In Vietnam, as well as in China, at all of levels of public authority, there exist parallel Party and government agencies that work together to shape the policy outcomes. The Party organs take the leadership role in providing the guidelines and direction to the state agencies. These guidelines set the direction without specifying all of the detail. Every year the Party Central Committee convenes at least twice to examine and deliberate on different policy alternatives and proposals submitted by state agencies. The PCC and its organs can request the state agencies to provide information and to organize hearings and deliberation. Notably, the Party is more concerned about the political acceptability of reform and its congruence with core regime values while the state agencies are responsible for technical feasibility. State agencies composed of various ministerial organizations and research institutes produce consultative reports and data. Even though, the boundary between Party's and State's functions is blurred, the democratic-centralism mechanism requires the state agencies to seek the guidelines from the party organs.

\section{Contribution of the proposed policy model to the policy process literature}

This dissertation aims at creating and validating a major policy change model for Vietnam in an effort to provide a better understanding of the politics of the policy process in Vietnam during its the transitional period. The author hopes that the 
proposed policy model along with the evidence from the four policy case studies can contribute to two bodies of literature. The first literature is related to the policy process theories and models that have been developed to explain policy change in the U.S and other countries. As I pointed in my literature review in Chapter III, most of these policy models have developed out of the American political process. Pioneering U.S. scholars have developed such theories as Punctuated-equilibrium (Frank Baumgartner and Bryan Jones), Advocacy Coalition (Paul Sabatier and JenkinsSmith), Multiple-stream (John Kingdon), Institutional Analysis and Development (Elinor Ostrom). An increasing number of scholars have applied the policy process theories and or developed different policy models in order to explain policy process in different policy contexts and political systems (Regime-policy model, Wilson, 2000; Focusing-event model, Birkland, 2006; Technical Infeasibility, Zhu, 2008; etc.). The question posed by these studies is the extent to which the explanatory capacities of the theories and models in policy analysis in different policy context including the context in centralized, transitional, and single-party countries.

The second body of literature is composed of research and studies on politics and policy reforms in Vietnam during its transitional period. Within this body of literature, there are two main sources of research. The first source focuses on descriptive inferences in different policy areas. For example, following are some of the important research conducted in each of four policy areas under this study:

- In higher education policy on institutional autonomy: Hayden \& Lam (2007), Tran (2009), Pham (2010), Luu (2010), Ho \& Berg (2010), Harvard Kennedy School of Government (2008, 2010) 
- State-owned enterprise: Painter (2003, 2005), Melanie Beresford (2008), Vu (2009), The Vietnam Consultative Group Meeting (2011)

- Trade liberalization: Athukarola (2006), Nguyen \& Haughton (2002), Pham (2011), Vo \& Nguyen (2009)

- Economic reforms: Kokko (1998), Dixon (2000, 2003), Le (2002), Abrami, (2003), Muller (2005), Meyer et al (2005), Chu \& Dickie (2006), National Assembly of Vietnam (2012).

The second source has used the language and theories of political science to study policy reforms in Vietnam including the research of McCormick, (1998), Dinh (2000), Nguyen (2000), Pierre (2000), Abuza, (2001), Painter (2003), Fritzen, (2000, 2002), Luong (2006), London (2009), Vu (2010). In addition to these sources of research, increasing number of studies on Vietnam politics and policy reforms has been developed from the works of international organizations such as WB, IMF, ADP, DFID, UN agencies, Harvard University, etc. Vietnam has increasingly been open and sought for technical and financial assistances from international donors and partners that allow for a larger number of independent reports produced or supported by various international organizations. Normally the studies sponsored by international organizations are able to provide in-depth and comprehensive research in specific policy areas or overall pictures of the socio-economic situation of Vietnam (Macroeconomic Report 2012: From instability to the path of restructuring conducted by the Economic Subcommittee of the National Assembly, in 2012; the White Paper on the Future of Higher Education in Vietnam conducted by the Harvard Kennedy School, and the Fulbright Economics Teaching Program (FETP) in Ho Chi Minh City and sponsored by the United Nations Development Program (UNDP) in 2010; 
Vietnam development report 2012: Market Economy for a middle-income Vietnam conducted by the Vietnam Consultative Group Meeting in 2011, etc.,. This body of literature, along with research on China politics and policies, has provided us with a much better understanding of the policy reform outcomes as well as constraints and insights of the politics of the communist and single-party countries represented by China and Vietnam.

Despite a remarkable development of these two bodies of research, to the knowledge of the author, no scholar or research has focused on developing a theoretical policy models to explain policy process and politics of reforms in Vietnam. Most researchers have concentrated on descriptive analysis to examine the policy problems, outcomes and solutions in a transitional Vietnam. Thus, this dissertation is expected to contribute to a better understanding of policy reforms and politics of Vietnam as following:

\section{Contribution to the literature body of policy process theory and model}

First, the dissertation confirms the popular views of the policy process theories and models that stressors are a precondition for an innovative policy change initiative to be advanced to the official agenda of the government. Stressors challenge the existing status quo of a policy subsystem and pave the way for different policy paradigm to be articulated. Pressures from stressors play a catalyst role in accelerating the process of change. In the cases of trade and legal reforms in this dissertation, radical policy change would likely not have occurred if there had not been the Asian Financial Crisis in 1997, which spawned an increased incentive on the part of Vietnam to liberalize international trade and adopt radical legal changes. The stressors identified in my four case studies illustrate that stressors can be both internal and 
external and can include a combination of economic, social, political factors that are triggered by policy changes in other areas. However, this dissertation along with other policy process theories and models reviewed in Chapter II argues that stressors do not automatically lead to radical changes. There must be other policy factors in place to push for the adoption of radical change. For example, in the case of state-owned management policy, despite increasing stressors, even scandals or the risks of economic collapse, the CPV and its government still stood firm on their will to maintain a large and strong state economic sector.

It should be noted that the concept of stressor is very broad and as argued by Thomas Birkland in his Focusing-event model, it is not easy to quantify and measure the magnitude of stressor influences on the policy process and outcomes. It seems easier to quantify the stressors in economic areas than in social areas. Among the four cases studies in this dissertation, the stressors in the higher education sector seem less visible and more abstract because there is a lack of a strong linkage between economic development and high education quality. In Vietnam, there is also an absence of a direct connection between higher education quality and more institutional autonomy. As a result, the predisposition to reform in this policy area seems weakest among the cases. The Vietnamese government acknowledges strong pressures but cannot realize exactly what they are.

Second, the concept of "leadership predisposition" is new in the literature even though the scholars have made reference to the importance of such a concept. For example, in the policy-elite policy choice model created by Thomas and Grindle (1991), the two authors used the concepts "ideological predisposition" to explain the ideological commitments of policy elites in the policy change process. Bruce Gilley 
(2010) used the phrase "subjective perceptions" to identify the difference in the political transformation between China and Taiwan. These concepts, together with the concept of "leadership disposition" to reform, help describe the policy change process in developing countries, especially in single-party and state-led political system. In this system, due to a weak civil society, more power and legitimacy is vested in the hand of policy elites and public officials compared to their counterparts in developed and democratic countries. Therefore, the role of the state and public agencies and its leaders in advancing policy change initiatives into the government agenda is clearer compared to pluralist systems. The concept of leadership predisposition helps to explain why international donors and agencies working with Vietnam sometimes feel disappointed in what they perceive to be arbitrary decision and the lack of democratic participation in the policy process and decision making practice in Vietnam even though the Vietnamese government has been very open hearing external ideas and different views. Being open to new and different ideas may not result in any predisposition to change. Leaders may think that a change is a good idea and will endorse it in general but not adopt it in particular because the timing is wrong or that it will undermine other values that have higher priority.

Third, the model and the empirical evidence of the policy case studies affirm the importance of policy image in the process of radical policy change. Without significant change in the policy image regarding the assessment of the problems and the solutions to resolve such problems, no innovative policy change alternative is like to occur. The policy image can be changed by the influences of stressors, by policy learning from feedback or additional information and studies. However, a powerful central ideology like socialism, communism, democracy, theocracy may prevent any 
change from occurring. This was certainly the case in Vietnam where the issue of state-owned enterprise management was seen as central to the prevailing socialist ideology and was too powerful to bring about many changes in the operation of SOG's and SEG's. While political leaders recognized the problems of low efficiency and corruption arising from state-ownership, they have opted to make marginal improvements rather than fundamentally restructure the relationship between state and the economy.

Fourth, this Model and evidence from the four case studies in this dissertation introduce the concept of "political value or principle" which serves as the filter for political acceptability in the case of Vietnam. As I have presented in Chapter III, this concept is similar to the concept of "deep core belief" introduced by Paul Sabatier (1988) in his Advocacy-coalition framework. Sabatier argued that deep core belief such as individual freedom, liberty or democracy are the embedded values in the U.S. society and cannot be changed. Since these values are inculcated in the society and public governance, the Sabatier's policy framework does not focus on "deep core beliefs" as an independent policy change factor. When this notion is applied to Vietnam, it means that the country's commitment to its deep core belief in socialism shapes defines and narrows the meaning of policy change factors like stressor, policy image, leadership predisposition to change, etc. This understanding of how "core political" beliefs interacts with other policy change factors helps us understand Vietnam's emphasis on preserving its core values in the face of strong internal and external pressures to reform. As a Socialist and transitional country, Vietnam has been exposed to the core beliefs from the outside world, especially from western democracies. Therefore, the regime has been challenged by these divergent values 
when its people have more communication and connection with other cultures and societies from the internet, press media, travel and global economic interdependence. As a result, the political leaders feel compelled to protect its Socialist legacies and characteristics of a single-party and party-led political system. These core political values play a gatekeeping role over the policy reform process and the role of the factors affecting major policy change.

\section{Contribution to the literature body of policy process and politics of reform in}

\section{Vietnam}

This dissertation contributes to a better understanding of the policy change and politics of reforms in Vietnam during Đổi Mới in different aspects. First, the process of initiating, deliberating, formulating and adopting a radical policy change in Vietnam is state-led. This does not necessarily mean that the state is closed to the outside world or ignores the policy inputs and ideas from the society. Instead, the state apparatus is composed of consultative agencies, research institutes and taskforces that help the state to communicate with the people and comprehend their aspirations. However, until present the state has been able to isolate the pressures and critics by international organizations and the people. The government's ability to rely on partycontrolled mediating institutions to collect and communicate information in the policy development process has been gradually undermined through economic reforms and technology, which have opened the country to more information from nongovernmental sources, both internally and from abroad. The regime has recognized these challenges but has been slow to make changes. It has opted for "experimental" and "pilot" governance practices with the hope that "as we go, we find our way". 
The second important point regarding the policy reforms during Đổi Mới is the increasing influence of external factors on Vietnam's development. The case of adopting many radical legal changes and policies in 2005 at the threshold of the WTO accession demonstrated a truth: as Vietnam integrated deeper into the world community, it would increasingly be affected by the outside world. Vietnam has responded to these pressures by creating a level playing field for economic enterprises, but it has done so in a proactive manner. Vietnam accepts reforms and changes but by its own pace and pathway. Powerful international organizations like the World Bank and the IMF have not succeeded in imposing their will on the pace and kind of policy reform undertaken by the government. Shivakumar (1996) in the article "Political parties, development policies and pragmatism in a changing world: Lessons from Vietnam" posited that "while one could question the role of institutions like the World Bank or IMF in formulating the economic reforms that began in 1989, it is obvious that they could not play a leading role in shaping the process of change undertaken by Vietnam". The Vietnamese government demonstrates recognition to address the concerns of its outside critics but do so in ways that harmonizing the desires of the donors with the interests of the regime.

The third lesson from these case studies regarding the essence of the policy process in Vietnam is the absolute leadership of the CPV over the government in policy reform process during Đổi Mới. Within the party-state system, any radical policy change initiative must be approved by the Party Central Committee. The Party takes the leadership role not only in determining the working agenda of the government and National Assembly but also in deciding the final approval to all major policy changes. Over the past years the government has tended to diminish this 
role of the Party. However, the recent $6^{\text {th }}$ Plenum of the CPV in October 2012

reaffirmed the decisive role of the CPV in maintaining its leadership over the state system. The regime wants to maintain a mechanism through which the integration and coordination between party and state units are effective in providing the necessary support to ensure that resources are optimally utilized for successful cause of industrialization and modernization.

The fourth important characteristic of the policy reform process in Vietnam is the reliance on collective-based decision making system. Even though the reforms are state-led, there is a democratic and deliberative mechanism within the Party Central Committee and government. In the small groups of political and policy elites, no single figure is in the position to impose his will on the policy process and outcome. This "internal democracy" has helped the CPV to access different points of view and allowed free debate on its policies and strategies. The outcome of the recent $6^{\text {th }}$ Plenum in October 2012 demonstrated that even the Politburo was not able to make final decisions without the consensus of the Party Central Committee. Thus, the principle of "democratic-centralism" is still a centerpiece of the Party's Charter that helps the Party encourage the internal Party democracy while maintaining centralization and control of the Party Central Committee.

\section{Limitations of the research and proposed future research}

This section identifies the limitations of this research study and proposes future research that builds on the findings of this study. 


\section{The limitations of the research}

Despite my efforts to develop a research that can provide comprehensive understanding of the policy process and politics of reform in Vietnam, the research has both content and methodological limitations

\section{Content limitations}

The first limitation in terms of content is related to the constraint of the proposed policy change model. The model only seeks to explain the policy change process from the triggering factors though the final state of adoption. The model does not extend policy change to include the implementation and evaluation stages of a policy cycle. In the practice of Vietnam, there is always a big gap between policy design and policy implementation. Therefore, it is important to develop another type of policy model that would help to explain how the policies in Vietnam are implemented at the local government level after they are designed and adopted by the central government.

The second content limitation is that due to the lack of information and data regarding the internal deliberation and discussion within the Party and government organs, the researcher was not able to describe in detail the internal policy image changes within the individual policy elites and within the leadership segments of the regime. In addition, the author has not been able to identify the actual mechanism to accommodate different points of views within the Party and government when the policy change alternatives are discussed and deliberated. This is a common issue for other researchers and scholars who cannot obtain access to the proceedings and documents of the secret and closed meetings of the Party and government. Over the past few years, there is increasing democracy within the National Assembly when 
hearings have been conducted to cabinet members including the Prime Minister and broadcasted lively on television. However, the questions are submitted in advance and the cabinet members have prepared the answers prior to the hearings. Also, the debated issues are oriented and selected by Standing Committee of the National Assembly after consulting the Party Central Committee. Most importantly, the Plenums of the CCP and the National Party Congress are not publicized and the press media agencies are still limited to broadcasting the contents of the outcomes. Party's meetings and debates are still considered as the internal affairs of the Party and its members.

The third limitation of the research is the lack of strong evidence to differentiate between the policy beliefs of the regime and the rhetorical policy statements of the policy and political elites. In the proposed policy model, I argued that to maintain the legacies of the Socialist state and legitimacy of the Party, political leaders have to advance their beliefs and make them dominant within the state and society. The principle of "democratic-centralism", however, does not allow senior public officials to publicly state their true beliefs, especially when the beliefs might conflict with the mainstream ideology and political values of the Party. Recently, there have been increasing critics and independent views challenging the policies and governance practices of the Party and government. However, these views and critics are advanced by retired and former senior policy elites only.

Last, there are still some difficulties in isolating political core values and principles of the CPV. It is also challenging to identify the intermediate political goals and their relationships to the political core values. For instance, I have identified two political core values of the CPV: political stability and absolute leadership role over 
the state and society. I have identified through my case studies some of the intermediate political goals that help the CPV to realize the core values: economic growth and higher living standards, social equality and coherence, state-led industrialization and modernization, social welfare for the masses and internal Party unity and solidarity. I have argued that at given points of time, based on the context, the Party and government reach consensus on giving the highest priority to specific intermediate goals. If such priority favors the given innovative policy change alternative, then radical change can be adopted. If not, there are only incremental changes or even intact outcomes. However, it is not clear whether and how a change in policy image inter-relates or affects the assessment of the political priorities at a given period of time. Also, the question still remains unclear in the case of conflict among the intermediate policy goals how does the Party resolve such conflicts. This part of the process has been inaccessible to study.

\section{Methods limitations}

Due to limitations on time and resource, this research only relied on document review data collection to gather the evidence. This included an examination of Party's and state's guiding resolutions, conclusions, legal documents, and policy elite interviews and statements on the internet, and independent academic research. This document review method was very helpful in providing empirical evidence related to the policy factors of stressors, leadership predisposition, policy image and consensus on political priority of the Party and government. However, it is limited in providing the access to information on the internal deliberations within the Party and government organs and on the actual policy beliefs of the elites. The method is also not able to shed light on the mechanism that the Party uses to accommodate different 
points of view to reach consensus. Among the case studies, the case of trade liberalization has the best information about the internal beliefs and the changing process of the policy image and the internal debates within the Party regarding the balancing of political priorities. For the other cases, even when we have access to publicized interviews with policy elites, most of their statements are censured and limited.

To offset the limitations of the research method used for the case studies in this dissertation, I have relied on a number of personal communications and interviews with senior officials at both the central and local government levels. Even though these interviews are not integrated into this dissertation, they have been very helpful in verifying some of the unclear issues and questions. In addition, my experience working in a central government agency in Vietnam gave me access to a practical understanding of the operations of the policy process and structure in Vietnam.

\section{Proposed future research}

Based on the results of this research and its limitations, there are several productive areas for future research. First, change in policy image is an important factor in bringing about major reform, but there is much that this study leaves open. For example, what are the various causal factors that bring about a change in policy image? Are there some models that can be developed? To what extent are these models applicable across different types of regimes?

In addition to the questions surrounding changes in policy image, there are unanswered questions of how changes in policy image interact with one's assessment of the importance of various political priorities. For example, the decision to adopt a 
market economy as part of one policy image model is very likely to make performance of the market economy a higher priority than had been the case in the past. Further research on issues on changes in policy image and its interplay with the setting of political priorities can assist international agencies in identifying the kinds of interventions that are most likely to result in major policy changes in Vietnam.

A second potential area for research is to clarify and differentiate the different concepts of "political core values", "intermediate political goals" and "socialist legacy" of the CPV. For example, I have argued that party control and state direction of the society have been the core political values of Vietnam with values like social equity, a harmonious society, social stability, economic prosperity as being intermediate political goals. But a case could be made that the core political values are governed by changes in the meaning of a socialist society. In other words, the core political values may be the source of real change. My study is not able to answer this question. These kinds of question can be better addressed by interviews with incumbent and former senior policy elites to get the better insights of the policy deliberation and internal working mechanism within the Party. The interviews can also help identify the internal personal policy beliefs of political leaders of the Party and government of Vietnam.

\section{Conclusion}

By employing the policy study languages and concepts instead of using political theories, this dissertation attempted to provide a new approach to explain the politics of policy reforms in Vietnam during the its transitional period of time. The major policy change model in the dissertation was developed based on the universal factors of change embedded in the well-developed policy process theories and models 
in the U.S. while founded on the regime characteristics of Vietnam. The model emphasized the role of stressor and regime's leadership predisposition to reform as the necessary and sufficient conditions for a policy change initiative to be advanced into the official agendas of the National Assembly and government of Vietnam. However, in order for a major/innovative policy change to be adopted, there must be a significant change in the policy image of the regime and its policy elites as well as the consensus on the temporary political priority within the regime favoring the policy change proposal.

The proposed policy model was proved to be helpful and relevant to the examination of the policy processes and outcomes in the policy case studies conducted in the dissertation. In the two cases with radical policy change (international trade liberalization and legal reform in foreign investment), the four policy factors identified in the model (stressors, leadership predisposition to reform, significant change in the policy image and Party consensus on temporary political priority) were present at different stages of the policy change process to induce the final radical change outcomes. In contrast, in the two cases without innovative change (higher education policy on institutional autonomy and state-owned enterprise management policy), the lack of significant change in the policy image has prohibited the formulation and articulation of innovative policy change proposal over the past decades in Vietnam. The study has found that the legacy of a Socialist state is the key barrier for the significant change in the policy image of the regime and its leaders in these two policy areas. The requirements of party/state control, social stability, and collective mastery still dominate the demand for policy innovation and efficiency in the policy areas of higher education and state economic management. 
The concepts and causal arguments of policy change in the proposed model along with the insightful evidence from the case studies in the dissertation contributed to the understanding of the policy process and reform in the single-party and transitional countries like Vietnam and China. They help uncover the "black box" of the politics of policy reforms in Vietnam over the last two decades. By referring to different policy stages of the policy change process with two kinds of "filer" (technical feasibility and political acceptability), the proposed policy model is capable of explaining the characteristics of policy reforms in Vietnam described by other scholars as gradualist or dual party-state approach. In addition, with the concepts of political principle and intermediate political goal, we can explain the seemingly pragmatic behaviors of the regime in Vietnam in policy-making process. When deliberating and deciding radical policy change, the regime on the one hand needs to maintain the core values and principles (political stability and Party leadership), on the other hand opens for various political goals at different points of time. 


\section{References}

Abonyi, G. (2005). Political economy of reform: case studies of Asian Development Bank supported by policy-based lending operations. ERD Working Paper No. 70 sponsored by Asian Development Bank. The Phillipines.

Abrami, R. M. (2003). Vietnam in 2002: on the road to recovery. Asian Survey, Vol. 43, No. 1 , 91-100.

Abuza, Z. (2001). The lessons of Le Kha Phieu: Changing rules in Vietnamese politics. Paper at Conference on Prospects for the Consituencies of Vietnam in Changing Times . Washington DC, United States.

American-Vietnamese Partnerships in Higher Education Annual Conference. (January 15-16, 2009). Higher Education in Vietnam. Hotel, Ho Chi Minh City, Vietnam.

Anderson, J. E. (2010). Public Policymaking: An Introduction (7th ed.). Boston, MA, US:

Cengage Learning.

Athukarola, P.-c. (2006). Trade policy reforms and the structure of protection in Vietnam. In The Author Journal Compilation (pp. 161-187). Oxford: Blackwell Publishing Ltd.

Baumgartner, F., \& Jones, B. (2009). Adendas and instability in American (2rd ed.). Chicago: The University of Chicago Press.

Baumgartner, F., \& Jones, B. (1993). Agendas and instability in American politics. Chicago: The University of Chicago Press.

Bennett, C., \& Howlett, M. (1992). The lessons of learning: Reconciling theories of policy learning and policy change. Policy Science, Vol. 25 , 275-294.

Beresford, M. (2008). Doi Moi in Review: The challenges of building market socialism in Vietnam. Journal of Contempary Asia, Vol. 38, No. 2 , 221-243.

Birkland, T. (2001). An introduction of the policy process. Washington DC: Georgetown University Press.

Birkland, T. (2006). Lesson of disaster: Policy change after catastrophic events. Washington DC: Georgetown University Press.

Blanco, I., Lowndes, V., \& Pratchett, L. (2011). Policy networks and governance networks: Towards greater conceptual clarity. Political studies review, Vol. 9 (3) , 297-308.

Bui, G. V. (2011). Dan Tri. Retrieved from http://dantri.com.vn/c25/s25-531656/se-hon-loanneu-giao-quyen-tu-chu-dong-loat-cho-cac-truong.htm

Bui, G. V. (2012). Dan Tri. Retrieved from http://dantri.com.vn/c25/s25-619392/thu-truonggddt-coi-noi-quyen-tu-chu-cho-moi-truong-dai-hoc.htm 
Bui, L. D. (2010). Vietnamnet. Retrieved from

http://vnn.vietnamnet.vn/chinhtri/201009/Cuong-linh-phai-vi-loi-ich-chinh-dang-cua-dantoc-936546/

Bui, V. Q. (2012). Master Plan on Restructuring the Entire Economy presented to the National Assembly.

Chu, H. T., \& Dickie, P. M. (2006). 1 Economic transition in Viet Nam: Doi Moi to WTO. Hanoi: Public Policy Training Program, Asian Development Bank.

Communist Party of Vietnam. (2011). Conclusion No 02 of the Politburo on the Socioeconomic Situation of 2011. Hanoi, Vietnam.

Communist Party of Vietnam. (2009). Conclusion No 242 of the Politburo on Continuing Implementaion of the Resolution No 2 and the Development Strategies for Education until 2020. Hanoi, Vietnam.

Communist Party of Vietnam. (2002). Conclusion No. 14 of the Party Central Committee on Education and Scentific Development Strategies until 2005 and 2010. 2nd Plenum under the VIII National Party Congress. Hanoi, Vietnam.

Communist Party of Vietnam. (2010). Conclusion of the Politburo on restructuring, renovation and development of state-owned enterprises.

Communist Party of Vietnam. (1996). Five-year Socio-economic Development Plan 19962000 . Promulgated at the VIII National Party Congress . Hanoi, Vietnam.

Communist Party of Vietnam. (2001). Resolution No 07 of the Politburo on International Economic Integration. Hanoi, Vietnam.

Communist Party of Vietnam. (2002). Resolution No 14 on continued renovation of mechanism and policy to encourage and create favaorable conditions for private economic sector. 5th Plenum of the Central Party Committee . Hanoi, Vietnam.

Communist Party of Vietnam. (1993). Resolution No 4 of the 2nd Plenum under the VII Party National Congress on Continued Renovation on Education and Training. Hanoi, Vietnam.

Communist Party of Vietnam. (1996). Resolution No. 2 on Development Strategy for Education and Training in the Period of Industrialization and Modernization till 2000. 2nd Plenum of the VIII Party National Congress of Vietnam . Hanoi, Vietnam.

Communist Party of Vietnam. (1998). Resolution No. 5-NQ/TW on the Socio-economic Missions of 1999. Produced at the 6th Plenum (first round) under the VIII Party National Congress.

Communist Party of Vietnam. (2001). Resolution of the 3rd Plenum under the IV Party Congress on continuing restructruring, renovation, development of state-owned enterprises. Hanoi, Hanoi. 
Communist Party of Vietnam. (1997). Resolution of the 4th Plenum of the Party Central Committee under the VIII National Party Congress on Economic Development.

Communist Party of Vietnam. (2001). Resolution of the 4th Plenum under the VIII Party National Congress.

Communist Party of Vietnam. (2011). Socio-economic Strategies period 2011-2020. Hanoi, Vietnam.

Communist Party of Vietnam. (2001). Socio-economic Strategy of the Period from 20012010. Produced at the IX Party National Congress .

Communist Party of Vietnam. (2001). The Policy Report of the IX Party National Congress.

Conway, T. (2004). Politics and the PRSP Approach: Vietnam case study. Working Paper 24 of UK Overseas Development Institute .

Damond, J. (2010). BTA va su "am khoi" cua mot cuoc chien. (L. Phuong, Interviewer)

Dan Tri Newspaper. (2012, 3 12). State-owned enterprise revenue.

Deleon, P. (1999). The stages approach to the policy process: What has it done? Where is it going? In P. A. Sabatier, Theories of the policy process (p. 19). Boulder, Colorado, US: Westview Press.

Department of Information Technology. (2011). Annual Statistical Report. Retrieved from Ministry of Education and Training, Vietnam:

http://www.moet.gov.vn/?page=11.10\&view=4446

Dinh , M. T. (2012). Presentation at the Fall Economic Forum of 2012. Vung Tau, Vietnam. Retrieved from http://vnexpress.net/gl/kinh-doanh/2012/10/no-xau-cua-doanh-nghiep-nhanuoc-toi-200-000-ty-dong/

Dinh, Q. X. (2000). The political economy of Vietnam's transformation process. Contemprory Southeast Asian: A Journal of International and Strategic Affairs, Vol. 22. issue 2 (12) .

Dion, D. (1998). Evidence and inference in the comparative case study. Comparative Politics, Vol. 30, No. 2 , 127-145.

Dixon, C. (2003). Developmental lessons of the Vietnamese transitional economy. Progress in Development Studies, Vol.3, No. 4 , 287-306.

Dixon, C. (2000). State versus capital: the regulation of the Vietnamese foreign sector. Singapore Journal of Tropical Geography, 279-294.

Dunn, W. (2008). Public Policy Analysis: An Introduction. New Jersey, US: Pearson. 
Electronic Newspaper of Vietnam State Bank. (2012, August 3). Hanoi, Vietnam. Retrieved from http://www.thoibaonganhang.vn/tin-tuc/5-thoai-von-dau-tu-ngoai-nganh--lo-thi-kho--lai-thi-tu-choi-3578.html

Fforde, A. (2004). Vietnam in 2003: The road to ungovernablity. Asian Survey, Vol. 44, No. 1 , 121-129.

Foote, V. (2010). BTA va su "am khoi" cua mot cuoc chien tranh. (L. Phuong, Interviewer)

Fritzen, S. (2000). Decentralization and local government performance: A comparative approach with application to social policy reform in Vietnam. PhD Dissertation. Princeton University.

Fritzen, S. (2002). The 'foundation of public administration'? Decentralization and its discontents in transitional Vietnam. Paper presented at the Asia Conference on Governance in Asia: cultural, ethics, institutional reform and policy change. Hong kong.

Fritzen, S., \& Muniraa, S. (2007). What influences government adoption of vaccines in developing countries? Social Science \& Medicine, vol. $65,1751-1764$.

Gainsborough, M. (2002). Political Change in Vietnam: In Search of the Middle-Class Challenge to the State. Asian Survey, Vol. 42, No. 5 (Sep. - Oct., 2002) , 694-707.

General Statistic Office of Vietnam. (2010). Household Living Standards Survey 201. Hanoi: General Statistic Office of Vietnam.

George, A. L., \& Bennett, A. (2005). Case Studies and Theory Development in the Social Science. Cambridge, Massachusetts: MIT Press.

George, A. ( 1997). The Role of the Congruence Method for Case Study Research. MacArthur Program on Case Studies. Georgetown University.

Gilley, B. (2008). Taiwan's democractic transition: a model for China? In Taiwan's decmocratic transition.

Grindle, M., \& Thomas, J. (1991). Public choices and policy change: the political economy of reform in developing countries. Baltimore, USA: The Johns Hopkins University Press.

Harvard Kennedy School of Government. (2008). Vietnamese higher education: Crisis and response.

Harvard Kennedy School, and the Fulbright Economics Teaching Program (FETP) in Ho Chi Minh City. (2010). White Paper on the Future of Higher Education in Vietnam. The United Nations Development Program (UNDP).

Hayden, M., \& Lam, Q. T. (2007). Institutional autonomy for higher education in Vietnam Higher Education. Research \& Development, Vol. 26, No. 1 , 73-85. 
Hayton, B. (2010). Vietnam: Rising Dragon. New Haven, US: Yale University Press.

Ho, P. T., \& Berg, D. (2010). Educational leadership challenges: Vietnam's system of higher education. Paper presented at the Asia Leadership Roundtable 2010. Hong Kong Institute of Education, Hong Kong.

Institute of International Education. (2004). Higher Education in Vietnam . Hanoi.

Kerkvliet, B. J. (2001). An approach for analyzing state-society relations in Vietnam.

SOJOURN Vol. 16, No. 2 , 238-78.

Kerkvliet, B. J. (1995). Village - State Relations in Vietnam: The Effect of Everyday Politics on De-collectivization. The Journal of Asian Studies, Vol. 54, No. 2 , 396-418.

Kingdon, J. (1995). Agendas, Alternatives, and Public Policies. NY, US: Longman Publishing Group.

Kokko, A. (1998). 8 Vietnam: ready for Doi Moi II? SSE/EFI Working Paper Series in Economics and Finance, No. 286.

Le , D. D. (2002). Foreign direct investment in Vietnam: results, achievements, challenges and prospect. Paper presented at the IMF Conference on Foreign Direct Investment . Hanoi, Vietnam.

Le, P. D. (2008). Studying the relationship between autonomy and accountability in education management and research at contemporary universities in Vietnam. Vietnam National Institute for Education Science.

Lieberman, J. (2002). Three Streams and Four Policy Entrepreneurs Converge: A Policy Window Opens. Education and Urban Society, 34: 438.

Lijphart, A. (1971). Comparative Politics and the Comparative Method. The American Political Science Review, Vol. 65, No. 3 (Sep., 1971) , 682-69.

Lindblom, C. (2004). The science of "muddling through" . In J. Shafritz, A. Hyde, \& S. Parkes, The classics of public administration. Belmon, CA.: Thomson Wadsworth.

London, J. (2009). Vietnam and the making of market-Leninism. The Pacific Review, Vol. 22, No. $3,375-399$.

Lowry, W. R. (2008). Can Bureaucracies Change Policy? Journal of Policy History, Volume 20, Number 2 , 287-306.

Luong, V. V. (2006). Vietnam in 2005: Economic momentum and stronger state-society diologue. Asian Survey, Vol. 46, No. 1 , 148-154.

Luu, H. (2010). An Overview of Vietnamese Higher Education in the Era of Globalization: Opportunities and Challenges. Working paper. Can Tho, Vietnam. 
Mai, T. L. (2012). Quyet dinh chan cung la quyet dinh sai. (L. Phuong, Interviewer)

Marsh, D., \& Rhodes, R. (1992). Policy Networks in British Government (2nd ed.). Oxford: Clarendon Press.

McCormick, B. (1998). Political Change in China and Vietnam: Coping with the Consequences of Economic Reform. The China Journal, No. 40, Special Issue: Transforming Asian Socialism. China and Vietnam Compared , 121-143.

McKinsey Global Institute. (2012). Sustaining Vietnam's growth: The productivity challenge. Hanoi: McKinsey \& Company in Vietnam.

Meyer, K. E., Tran, Y. T., \& Nguyen, H. V. (2005). Doing business in Vietnam. Working paper No. 58 at the Center for East Europe Studies. Denmark.

Ministry of Education and Training, Vietnam. (2010). Guideline No 4713 on the Focused Mission of Higher Education in the 2010-2011 School Year. Hanoi, Vietnam.

Ministry of Education and Training, Vietnam. (2009). Report on the development of higher education system, solutions to quality assurance and training quality improvement. Hanoi.

Ministry of Education and Training, Vietnam. (2010). Resolution No. 05-NQ/BCSD on Innovation in Higher Education Management in the Period 2010-2012. Party Resolution . Hanoi, Vietnam.

Ministry of Industry and Trade of Vietnam. (2003). ACCESSION OF VIETNAM TO THE WORLD . Mintrom, M., \& Norman, P. (2009). Policy entrepreneurship and policy change. The Policy Studies Journal, Vol. 37, No. 4 .

Morgan, D. F., Green, R., Shinn, C. W., \& Robinson, K. S. (2008). Foundations of public service. NY: M.E.Sharpe.

Mortensen, P. (2005). Policy punctuations in Danish local budgeting. Public Administration Vol. 83, No. 4 , 931-950.

Muller, H. S. (2005). Private-sector development in a transition economy: the case of Vietnam. Development in Practice, Vol. 15, No. 3/4 , 349-361.

National Assembly of Vietnam. (2012). Macroeconomic Report 2012: From instability to the path of restructuring. Hanoi: The Economic Subcommittee.

National Assembly of Vietnam. (2009). Resolution No 42/2009/QH12 on Increasing the Law Enforcement and Policy Implementation in Management, Resource Usage, Asset Management of SEGs and State General Corporation.

National Assembly of Vietnam. (2008). Resolution on Implementing pilot project on abolishing the people's councils at district and commune level. Hanoi. 
National Assembly, Vietnam. (2010). Resolution No 50 on the Implementation of Policy and Law in the Establishment of New Institutions, Investment and Quality Assurance in Higher Education. Hanoi, Vietnam.

Ness, E. (2010). The politics of determining merit aid eligibility criteria: an analysis of the policy process. The journal of higher education, Vol. 81, No. 1 .

Ngo, K. K. (2011). Interview on Dan Tri Electronic Newspaper. (D. T. Newspaper, Interviewer)

Nguyen, A. N. (2007). Foreign direct investment in Vietnam: An overview and analysis of the determinants of spatial distribution across provinces. Working paper. Development and Policies Research Center.

Nguyen, B. N., \& Haughton, J. (2002). Trade liberalization and foreign direct investment in Vietnam. ASEAN Economic Bulletin Vol 19 No 3 , 302-18.

Nguyen, D. L. (2010). Dam Phan Viet-My: Chuyen bay gio moi ke. (L. Phuong, Interviewer)

Nguyen, D. T. (2006). Vietnam Prime Minister's address celebrating Vietnam's participation in WTO . Retrieved 6 10, 2012, from Dien Dan Doanh Nghiep:

http://dddn.com.vn/19854cat122/phat-bieu-cua-thu-tuong-nguyen-tan-dung-nhan-su-kienviet-nam-gia-nhap-wto.htm

Nguyen, H. M. (2000). The Party's choice. Asian Survey, Vol. 40, No. 1 , 98-111.

Nguyen, H. T. (2007). Vietnam practice in investment-related policy formulation and the PFI. Paper presented at the ARTNet Consulstative Meeting on Trade and Invesment Policy Coordination . Bangkok, Thailand.

Nguyen, H. (n.d.). The Impact of Globalization on Higher Education in China and Vietnam: Policies and Practices. Working paper: Simon Fraser University . Canada.

Nguyen, K., Oliver, D., \& Priddy, L. (2009). Criteria for Accreditation in Vietnam's Higher Education: Focus on Input or Outcome? Quality in Higher Education, Vol. 15, No. 2 .

Nguyen, N. T. (2010). Deputy Prime Minister's Announcement No 113 on Market-driven Education and Training period 2008-2015. Hanoi, Vietnam.

Nguyen, T. P. (2012). Closing Speech at the 6th Plenum of the Party Central Committee of the XI Party National Congress of Vietnam.

Nguyen, X. P. (2012). Testimony to the National Assembly.

Nguyen, X. T., \& Xing, Y. (2008). Foreign direct investment and exports: The experiences of Vietnam. Economics of Transition, Vol. 16 (2) , 183-197. 
Nohrstedt, D. (2009). Do Advocacy Coalitions Matter? Crisis and Change in Swedish Nuclear Energy Policy Advance Access. Journal of Public Administration Research and Theory, Inc by Oxford University Press .

Nuffic-Neso in Vietnam. (2009). Vietnam's Higher Education - Trends and Strategies. Retrieved from http://www.nuffic.nl/home/docs/neso/neso-e-newsletter/2010/vietnamshigher-education-trends-and-strategies.pdf

Olsson, J. (2009). The Power of the Inside Activist: Understanding Policy Change by Empowering the Advocacy Coalition Framework (ACF). Planning Theory \& Practice, Vol. 10, No. $2,167-187$.

Ostrom, E. (1999). Instituional rational choice: an assessment of the institutional analysis and development framework. In P. Sabatier, Theories of the policy process (p. 35). Boulder, Colodaro, US: Westview Press.

Painter, M. (2003). The politics of economic restructuring in Vietnam: the case of stateowned enterprise "reform". Contemporary Southeast Asia, vol. 25, No. 1.

Painter, M. (2005). The Politics of State Sector Reforms in Vietnam: Contested Agendas and Uncertain Trajectories. The Journal of Development Studies, Vol.41, No.2 , 261-283.

Painter, M. (2003). Public Administration reform in Vietnam: problems and prospects. Public Administration and Development, Vol. $23,259-271$.

Parsons, C., \& Fidler, B. (2005). A New Theory of Educational Change: Punctuated Equilibrium: The Case of the Internationalization of Higher Education. British Journal of Educational Studies, Vol. 53, No. 4, 447-465.

Pham, D. H. (2010). A comparative study of research capabilities of East Asian countries and implications for Vietnam. High Education, Vol. 605, 615-62.

Pham, H. T. (2011). Does WTO accession matter for the dynamics of foreign direct investment and trade? Vietnam's new evidence. Economics of Transition, Vol. 19 (2) , 255285.

Pierre, A. J. (2000). Vietnam's contradiction. Foreign Affairs, Vol. 79, No. 6 , 69-86.

Prime Minister of Vietnam. (2011). Decision No 14 on criteria and categorization for stateowned enterprise restructuring. Hanoi, Vietnam.

Prime Minister of Vietnam. (2012). Decision No 929 Rectifying the Program of Restructuring State-owned Enterprises within an Emphasis on State Economic Groups and Corporations in the Preiod 2011-2015.

Prime Minister of Vietnam. (2009). Decree No 101 on Pilot Establishment of State Economic Groups. 
Prime Minister of Vietnam. (2010). Directive No 296 on Innovation in Educational Management. Hanoi, Vietnam.

Prime Minister, Vietnam. (2001). Decree No: 201/2001/QĐ-TTg onVietnam National Education Development Strategy in the period of 2001 to 2010.

Robert, N., \& King, P. (1996). Transforming public policy: dynamics of policy entrepreneurship and innovation. San Francisco: Jossey-bass Published.

Sabatier, P. (1988). An advocacy coalition framework of policy change and the role of policyoriented learning. Policy Sciences, Vol. 21 , 129--168.

Sabatier, P. (1993). The Advocacy Coalition Approach . In P. Sabatier, \& Jenkins-Smith, Policy Change and Learning: An Advocacy Coalition Approach. Boulder, Colorad: Westview Press.

Sabatier, P. (1999). Theories of the Policy Process (2nd ed.). Colorado: Westview Press.

Sabatier, P. (2006). Theories of the Policy Process (3rd ed.). Colorado: Westview Press.

Sabatier, P., \& Jenkins-Smith, H. C. (1999). The Advocacy-coalition Framework: An assessment. In P. Sabatier, Theories of the policy process (p. 117). Boulder, Colodaro, US: Westview Press.

Schlager, E., \& Blomquist, W. (1996). A Comparison of Three Emerging Theories of the Policy Process. Political Research Quarterly, Vol. 49, No. 3 (Sep., 1996) , 651-672.

Shivakumar, M. S. (1996). Political Parties, development policies and pragmatism in a changing world: Lessons from Vietnam. Economic and Political Weekly, Vol. 31, No. 50 , 3255-3264.

The Conclusion No 14-KL/TW of the Politburo. (2002). The 6th Plenum of the IX National Party Congress. Communist Party of Vietnam.

The Vietnam Consultative Group Meeting. (2011). Vietnam development report 2012: Market Economy for a middle-income Vietnam. Hanoi.

The World Bank. (2012). Retrieved from

http://data.worldbank.org/country/vietnam\#cp_wdi

Theodoulou, S., \& Kofinis, C. (2004). The art of the game: understanding American public policy making. California: Thomson Wadsworth.

Tran, G. X. (2000, November). Planning and investment Minister Tran Xuan Gia on foreign investment and the Vietnamese business environment. The Academy of Management Executive. (J. J. Schermerhorn, Interviewer)

Tran, H. (2009). The transformation of higher education in Vietnam after Doi Moi: a story of "dualism". Dissertation at St. John's University, New York . 
True, J. L., Jones, B. D., \& Baumgarner, F. R. (1999). Punctuated-Equilibrium Theory: Explanning stability and change in American policymaking. In P. Sabatier, Theories of the policy process. Boulder, Colorado, US: Westview Press.

Vietnam Education Law. (1998). Hanoi, Vietnam.

Vietnam Enterprise Law. (2005). Hanoi, Vietnam.

Vietnam Higher Education Law. (2012).

Vietnamese Government. (2005). Resolution No 14 on Fundamental and Comprehensive Renovation in Vietnam Higher Education System. Vietnam.

Vietnamese Government. (2009). Decree No 101 on Pilot Establishment, Organization, Operation and Management on State Economic Groups. Hanoi, Vietnam.

Vietnamese Government. (2011). Decree No 59 on Transforming 100\% State-owned Enterprises to Joint-stock Companies. Hanoi, Vietnam.

Vietnamese Government. (2011). Resolution No 11 on the Solutions to Control Inflation, Stablize Macro-economic Situation and Ensure Social Welfares. Hanoi, Vietnam.

Vietnamese National Assembly. (2010). Resolution No 05 on Higher Education. Hanoi, Vietnam.

Vietnamese National Assembly. (2009). Resolution No 42 on Increasing Law Enforcement, Effectiveness of Policy Implementation and Public Asset Management in State Economic Groups and Corporations. Hanoi, Vietnam.

Vneconomy. (2012). State-owned Enterprises are in debts of 415 thousand billions VND. Hanoi, Vietnam.

Vo, T. T., \& Nguyen , D. A. (2009). Vietnam after two years of WTO accession. ASEAN Bulletin Vo. 20, No. $1,115-35$.

$\mathrm{Vu}, \mathrm{K} . \mathrm{M}$. (2009). Economic reform and performance: a comparative study of China and Vietnam. China: an International Journal 7, 2 , 189-226.

$\mathrm{Vu}, \mathrm{A} . \mathrm{T}$. (2011). Restructuring state-owned enterprises in Vietnam. Working paper contracted by the Economic Committee of the Vietnamese National Assembly. Retrieved from http://ecna.gov.vn/ct/ht/Lists/BaiViet/Attachments/170/Vu\%20Thanh\%20Tu\%20Anh.pdf $\mathrm{Vu}, \mathrm{H}$. T. (2010). The relationship between economic freedom and economic growth : the transition process in Vietnam and China. Thesis Project . Kentucky, United States.

Vu, T. (2012). Countries at the crossroads 2012: Vietnam. Freedom House. 
Vuong, H. D. (2011). Solutions for restructuring state-owned enterprises with emphasis on state economic groups and general corporations. Address at the Seminar on Restructuring the Economy . Hanoi, Vietnam.

Walgrave, S., \& Varone, F. (2008). Punctuated Equilibrium and Agenda-Setting: Bringing Parties Back in: Policy Change after the Dutroux Crisis in Belgium. An International Journal of Policy Administration, and Institutions, Vol. 21, No. 3 .

Wilson, C. (2000). Policy Regime and Policy Change. Journal of Public Policy, Vol. 20, No. 3 , 247-274.

World Bank. (2011). World Bank Country Data. Retrieved from http://data.worldbank.org/country/vietnam

Yin, R. (1999). Enhancing the Quality of Case Studies. Health Services Research .

Zhu, X. (2008). Strategy of Chinese policy entrepreneurs in the third sector: challenges of “Technical Infeasibility”. Political Science, Vol. 41, 315-334. 


\section{Appendix: Key contents of Vietnam Higher Education Law of 2012 related to institutional autonomy of higher education institutions}

The Higher Education Law was promulgated by the Vietnamese National Assembly in June 2012. The following review is to reveal that even in this law, the Socialist legacy of centralized control still trumps the demand for decentralization as a strategy to reform the higher education system in Vietnam.

\section{The goals of higher education}

There is a difference in terms of the goals of higher education between the Higher Education Law of 2012 and the Education Law of 2005. Indeed, in the Education Law of 2005, the first goal of higher education is to "educate learners in acquiring political and moral competencies and public spirit”. This goal is given higher priority than the goal of "acquiring knowledge and practical skills relevant to different educational levels; and acquiring good health, thereby meeting the needs for national construction and defense" (Article 39, Education Law of 2005). In contrast, in the Higher Education Law of 2012, the goals of developing human resource, improving literacy, training talents, conducting scientific and technological research and producing new knowledge for the sake of economic development, national security and international integration are prior to the goals of educating learners in acquiring political and moral competencies and public spirit (Article 5, Higher Education Law of 2012).

The Education Law of 2005 asserted that the Vietnamese education system is the socialist education system founded on Marxism-Leninism and Ho Chi Minh Thought. Although this principle has not been repeated in the new Higher Education 
Law of 2012, Article 3 of this law asserts that the organization and administration of higher education institutions is still subjected to the Education Law of 2005 and other state legal documents. That means that the Education Law of 2005 still has governing authority over state management of the higher education institutions.

\section{Party organization and committee within higher education institutions}

According to Article No. 13 of the Higher Education Law of 2012, the Communist Party of Vietnam's committees are established and operated within every higher education institution based on the Party's Charter and under the Constitution and relevant laws. Higher education institutions are responsible for the creation of necessary conditions for Party's organizations and social associations to be established and operated within the institutions. It means that the Party and government want to maintain Party leadership within every higher education institution, including private ones.

\section{University council and president}

The roles of university council have been articulated and promoted in various legal documents since the beginning of 2000 as the way to delegate the administrative rights from the state agencies to the higher education institutions. This law again reiterates and concretizes the roles and functions of the university councils. The law clearly gives university councils the authorities over: (1) Governing strategies, development plans, and the organizational charter of the institutions; (2) Training, scientific research, international relations and quality assurance plans and strategies of the institutions; (3) Organizational structure and investment plans of the institutions; (4) The division, merge or abolishment of units within the institution; (5) The 
implementation of plans and strategies identified by the councils and the democratic process within the institutions.

However, the chairs of the university councils are appointed by the relevant public authorities. Also, the presidents of the higher education institutions are appointed by the public authorities such as the Ministry of Education and Training, other line ministries or provincial people's committees. Notably, the first criterion for an appointed president is "political competence and good morality" which in Vietnamese means compliance with and loyalty to the political values and leadership of the CPV.

\section{Open new academic programs}

Under the Higher Education Law of 2012, the Minister of Education and Training has the right to regulate the criteria, phases and procedures to allow or to stop the operation of any academic program of every higher education institution at the undergraduate, master or doctoral levels. The national universities and other institutions that can meet the national standards and qualifications set by the Ministry of Education and Training have the autonomous rights and responsibilities in opening new programs at all levels with two conditions: (1) the program must be in the list of permitted programs promulgated by the Ministry of Education and Training; and (2) the program must demonstrate the appropriate training capacity to deliver the program. National universities are allowed to open new programs not on the permitted list of MOET as pilot projects but the importance of such program need to be justified by the Ministry of Education and Training and to obtain formal approval before they are officially taught as regular programs. 


\section{Content of academic curriculum}

Institutions are allowed to design the curriculum for all of their programs. However, the Ministry of Education and Training regulates the minimum amount of studying time (credit) for the accomplishment of every program; requirement of skills and capacities for graduation; the procedures of designing, accrediting, and promulgating the curriculum; the compulsory courses for the programs managed by foreign-owned institutions and joint-venture programs; and the procedures to compose, and select all textbooks. The Ministry of Education and Training composes the curriculum and textbooks for the political, security and national defense courses which must be taught at every institution.

For the foreign-owned programs and institutions, they can use their own curriculum. But they must guarantee that their curriculums have been accredited by recognized accrediting associations in their home countries and that the learning contents must not adversely impact social security, national and community interests and must not violate or distort history, traditions, and the moral rules of Vietnam (Article 36). The joint-venture programs conducted in any Vietnamese higher education institutions, except for those offered under the auspice of the national universities, must meet the conditions for quality assurance set by the government and must be approved by the Ministry of Education and Training.

\section{Accreditation}

Article 51 of the Higher Education Law of 2012 asserted that every institution is subjected to accreditation whenever required by the public authorities. They also need to provide necessary information and report on quality assurance requested by the Ministry of Education and Training. MOET has the right to regulate the national 
standards for every higher education institutions; evaluation and accreditation criteria; standards for curriculum at all training levels; the minimum requirements of skills and capacities for graduation of all programs; the accrediting procedures; and the operational mechanism, and the criteria for the establishment and operation of accrediting organizations within the system. The accreditation results will be used by the government agencies to identify the relevant autonomous rights for individual institutions. The relevant public agencies will also use the accrediting results when they decide the budget or investment for individual institutions. While the law refers to the establishment of independent accrediting associations, it has not identified the specific conditions and procedures to establish and operate such organizations yet.

\section{Student enrolment and admission process}

According to recent policy change in student admission, the higher education institutions are autonomous in identifying the enrollment quota for themselves, but they are required to publicize student quota and conditions to manage and assure the quality. Institutions have the right to employ different admission methods such as the national entrance exams or profile examination. The Ministry of Education and Training, however, reserves the right to regulate the methods to identify the enrolment number and admission procedures applied to every institution. For example, the ministry administrates and organizes the national entrance examination, sets the minimum (floor) score for admission to any institution, and the timeline for the admission process annually. Also, even though institutions do not need to get the approval for their enrollment quota from the MOET, they do need to send a report to MOET regarding their enrolment quota and the conditions to ensure the quality. 


\section{Institution classification in higher education}

One of the new points in this Higher Education Law of 2012 compared to other previous legal documents is the institutional classification under Article 9. Accordingly, higher education institutions are classified based on different criteria: (1) the relative role and position within the higher education system; (2) the scope, discipline and level of education and training programs; (3) the proportion between training and research activities; (4) the quality of training and research; (5) the feedback resulting from accreditation. Based on these criteria, three kinds of institutions will be identified as one of the following: (1) Research institutions; (2) Application-oriented institutions; and (3) Profession institutions. The goal of this classification is for the government to use it as the guide to the investment policy, especially to deal with the policy question regarding the need to decentralize the higher education system. The law anticipates that institutions of higher rank and quality will be given more institutional autonomy and rights compared to the lower tier ones. The government controls the standards and accrediting criteria for the classification of institutions. The law provides that the Prime Minister will recognize the ranking and order of institutions.

According to the law, the two national universities are granted a higher level of autonomy in education and training activities, scientific research, finance management, international cooperation and organizational structure compared to the rest of the institutions. They can work directly with ministry-level agencies, provincial people's committees and can report directly to the Prime Minister when necessary. However, they are under the state management of the Ministry of Education and Training and their presidents and vice presidents are appointed and removed by the 
Prime Minister. The government continues to regulate concrete functions, missions and rights of the national universities. Overall, the government is in the chief control position in designing policies and creating regulations in higher education based on the development of the accreditation and classification system.

\section{Procedures for the establishment and operation of the higher education} institutions

The Prime Minister reserves the rights to regulate the criteria and procedures for the establishment and operation of four-year institutions, including foreign-owned institutions. The Minister of Education and Training has the right to regulate the criteria and procedures for the establishment and operation of the junior institutions (two-year colleges). Also, the Prime Minister decides and approves in principle the establishment of new public, private and foreign-invested four-year institutions while the Minister of Education and Training has the rights to permit the establishment of two-year, both public and private, colleges.

In terms of the missions and rights of higher education institutions, the law has reiterated the general missions and rights in 10 administrative aspects, including: planning; operational activities such as training, research, quality assurance, and international relations; developing training program based on the missions, and ensuring the integration between different level of education; managing organizational structure, staff recruitment, teacher training, and human resource management; managing students and ensuring the legalized rights of teachers, staff and students; self-evaluation and being subjected to accreditation assigned by the government; the right to use land and receive tax exemption; mobilizing resources for development; cooperating with domestic and international organizations for mutual benefit; being 
responsible for report to the Ministry of Education and Training and other public agencies. Even the foreign-owned institutions have to report to the Ministry of Education and Training and the local governments on a regular basis a variety of administrative activities.

It should be noted that following other documents, institutional autonomy for the higher education institutions including personnel management, asset and facility management, training and scientific research activities, international relations, and quality assurance are articulated in this law. However, these institutional rights are limited and conditioned because autonomous rights given to certain institutions depending on the capacities and the ranks of such institutions revealed by the result of the accreditation which in turn be recognized by the government agencies.

\section{Setting tuition and fee in higher education}

According to the law, the government reserves the right to regulate the method to identify the tuition and fee levels of public institutions. The private and foreigninvested institutions have the right to identify their tuition and fee rates within the framework set by the government. Private institutions must use at least $25 \%$ of the added value between expenditure and income (profit) for reinvestment. Notably, the law avoids using the sensitive word "profit" in education. Also, the withdrawal of capital of the investors in private institutions must be under the strict regulations of the government in order to ensure the stability and development of the institutions. 